\title{
UNFCCC NATIONALLY Determined ContRIBUtions: Climate Change and Trade
}

\author{
9 January 2017, Geneva \\ Submitted by \\ Rana Elkahwagy, Vandana Gyanchandani, Dario Piselli
}

To: Alexey Vikhlyaev

United Nations Conference on Trade and Development

TradeLab output is prepared on a pro bono basis by students as a pedagogical exercise. It is not professional legal advice and in no way establishes a client-attorney relationship. 


\section{TradeLab}

International rules on cross-border trade and investment are increasingly complex. There is the WTO, World Bank and UNCTAD, but also hundreds of bilateral investment treaties (BITs) and free trade arrangements ranging from GSP, EU EPAs and COMESA to ASEAN, CAFTA and TPP. Each has its own negotiation, implementation and dispute settlement system. Everyone is affected but few have the time and resources to fully engage.

TradeLab aims to empower countries and smaller stakeholders to reap the full development benefits of global trade and investment rules. Through pro bono legal clinics and practica, TradeLab connects students and experienced legal professionals to public officials especially in developing countries, small and medium-sized enterprises and civil society to build lasting legal capacity. Through 'learning by doing' we want to train and promote the next generation of trade and investment lawyers. By providing information and support on negotiations, compliance and litigation, we strive to make WTO, preferential trade and bilateral investment treaties work for everyone.

More at: https://www.tradelab.org

\section{What are Legal Clinics}

Legal Clinics are composed of small groups of highly qualified and carefully selected students. Faculty and other professionals with longstanding experience in the field act as Academic Supervisors and Mentors for the Clinics and closely supervise the work. Clinics are win-win for all involved: beneficiaries get expert work done for free and build capacity; students learn by doing, obtain academic credits and expand their network; faculty and expert mentors share their knowledge on cutting-edge issues and are able to attract or hire top students with proven skills.

Clinic projects are selected on the basis of need, available resources and practical relevance. Two to four students are assigned to each project. Students are teamed up with expert mentors from law firms or other organizations and carefully prepped and supervised by Academic Supervisors and Teaching Assistants. Students benefit from skills and expert sessions, do detailed legal research and work on several drafts shared with supervisors, mentors and the beneficiary for comments and feedback. The Clinic culminates in a polished legal memorandum, brief, draft law or treaty text or other output tailored to the project's needs. Clinics deliver in three to four months. Work and output can be public or fully confidential, for example, when preparing legislative or treaty proposals or briefs in actual disputes.

\section{Centre for Trade and Economic Integration (CTEI)}

CTEI is the Graduate Institute's Centre of Excellence for research on international trade. The Centre brings together the research activities of eminent professors of economics, law and political science in the areas of trade, economic integration and globalization. The Centre provides a forum for discussion and dialogue between the global research community, including the Institute's student body and research centres in the developing world, and the international business community, as well as international organisations and NGOs. The Centre runs research projects and organises events. A core goal of the Centre is to foster genuine, interdisciplinary research and to work across discipline to foster solutions that address the major societal issues of today. The Centre for Trade and Economic Integration fosters worldclass multidisciplinary scholarship aimed at developing solutions to problems facing the international trade system and economic integration more generally. It works in association with public sector and private sector actors, giving special prominence to Geneva-based International Organisations such as the WTO and UNCTAD. The Centre also bridges gaps between the scholarly and policymaking communities though outreach and training activities in Geneva.

More at: www.graduateinstitute.ch/ctei 


\section{Table of Contents}

LIST OF ABBREVIATIONS

EXECUTIVE SUMMARY $\quad$ E

1. INTRODUCTION

2. MAPPING TRADE-RELATED RESPONSE MEASURES IN INDCS/NDCS

2.1. INTRODUCTION AND SCOPE OF THE MAPPING 5

2.2. METHODOLOGY AND MAPPING FORMAT 2

2.3. FINDINGS 8

3. THE INTERPLAY BETWEEN ECONOMIC DIVERSIFICATION AND RESPONSE MEASURES IN \begin{tabular}{lr}
\hline THE INDCS/NDCS & 17 \\
\hline
\end{tabular}

$\begin{array}{lr}\text { 3.1. INTRODUCTION } & 17\end{array}$

3.2. ECONOMIC DIVERSIFICATION IN THE UNFCCC WORK STREAMS 17

3.3. POTENTIAL IMPACTS OF RESPONSE MEASURES ON ECONOMIC DIVERSIFICATION 19

3.4. FRAMING THE MAPPING OF RESPONSE MEASURES THROUGH THE LENSES OF ECONOMIC DIVERSIFICATION

3.5. TRADE RULES AS A PRECONDITION FOR PROMOTING ECONOMIC DIVERSIFICATION THROUGH RESPONSE MEASURES

4. THE INCORPORATION OF CLIMATE-RELATED MEASURES INTO FREE TRADE AGREEMENTS

$\begin{array}{lr}\text { 4.1. INTRODUCTION AND METHODOLOGY } & 34\end{array}$

4.2. THE ARCHITECTURE OF CLIMATE CHANGE PROVISIONS IN FTAS 36

4.3. CLIMATE-RELATED MEASURES INCLUDED IN FTAS 37

4.4. EXCEPTIONS ALLOWING THE IMPLEMENTATION OF RESPONSE MEASURES 44

5. CONCLUSION 47

\begin{tabular}{lr} 
BIBLIOGRAPHY & 50 \\
\hline
\end{tabular}

\begin{tabular}{lr} 
ANNEX 1: COUNTRY SUMMARIES & 54 \\
\hline
\end{tabular}

ANNEX 2: INDCS/NDCS WITH NO OFFICIAL OR UNOFFICIAL TRANSLATION SUBMITTED 241 


\section{List of Abbreviations}

\begin{tabular}{|c|c|}
\hline ADB & Asian Development Bank \\
\hline AFOLU & Agriculture, Forestry and Other Land Use \\
\hline APEC & Asia Pacific Economic Cooperation \\
\hline AWG-KP & $\begin{array}{l}\text { Ad Hoc Working Group on Further Commitments for Annex I Parties under the } \\
\text { Kyoto Protocol }\end{array}$ \\
\hline BAPCO & Bahrain Petroleum Company \\
\hline BAU & Business as Usual \\
\hline BIT & Bilateral Investment Treaty \\
\hline BOAD & Banque Ouest Africaine de Developement \\
\hline CARIFORUM & Caribbean Forum \\
\hline CDM & Clean Development Mechanism \\
\hline CETA & Comprehensive Economic and Trade Agreement \\
\hline CFLs & Compact Fluorescent Lamps \\
\hline COP & Conference of the Parties \\
\hline CSP & Concentrated Solar Power \\
\hline CTCN & Climate Technology Center and Network \\
\hline DSM & Demand-side Management \\
\hline EAEU & Eurasian Economic Union \\
\hline ECOWAS & Economic Community of West African States \\
\hline EGA & Environmental Goods Agreement \\
\hline EPA & Economic Partnership Agreement \\
\hline FDI & Foreign Direct Investment \\
\hline FITs & Feed-In-Tariffs \\
\hline FTAs & Free Trade Agreements \\
\hline GCC & Gulf Cooperation Council \\
\hline GCF & Green Climate Fund \\
\hline
\end{tabular}




\begin{tabular}{|c|c|}
\hline GDP & Gross Domestic Product \\
\hline GEF & Global Environment Facility \\
\hline GEI & Gases de Efecto Invernadero \\
\hline GES & Gaz à Effet de Serre \\
\hline GGP & Green Government Procurement \\
\hline GHG & Greenhouse Gas \\
\hline HCFCs & Hydrochlorofluorocarbons \\
\hline HFCs & Hydrofluorocarbons \\
\hline IDB & International Development Bank \\
\hline INDC & Intended Nationally Determined Contribution \\
\hline IPCC & Intergovernmental Panel on Climate Change \\
\hline ال & Joint Implementation \\
\hline LDCs & Least Developed Countries \\
\hline LULUCF & Land Use, Land-Use Change and Forestry \\
\hline MRV & Monitoring, Reporting and Verification \\
\hline NAMAs & Nationally Appropriate Mitigation Actions \\
\hline NDC & Nationally Determined Contribution \\
\hline NG & Natural Gas \\
\hline OJ & Official Journal of the European Union \\
\hline PDVSA & Petróleos de Venezuela, S.A. \\
\hline PPMs & Process and Production Methods \\
\hline PVs & Photovoltaics \\
\hline$R \& D$ & Research and Development \\
\hline RPS & Renewable Portfolio Standards \\
\hline RTA & Regional Trade Agreement \\
\hline SBI & Subsidiary Body for Implementation \\
\hline
\end{tabular}




$\begin{array}{ll}\text { SBSTA } & \text { Subsidiary Body for Scientific and Technological Advice } \\ \text { SDGs } & \text { Sustainable Development Goals } \\ \text { TES } & \text { Thermal Energy Storage } \\ \text { TPP } & \text { Trans-Pacific Partnership } \\ \text { UNDP } & \text { United Nations Development Programme } \\ \text { UNEP } & \text { United Nations Environment Programme } \\ \text { UNFCCC } & \text { United Nations Framework Convention on Climate Change } \\ \text { UNGA } & \text { United Nations General Assembly } \\ \text { UNTS } & \text { United Nations Treaty Series } \\ \text { UT-CUTS } & \text { Uso de la Tierra, Cambio de Uso de la Tierra y Silvicultura } \\ \text { WAEMU } & \text { West African Economic and Monetary Union } \\ \text { WTO } & \text { World Trade Organization }\end{array}$




\section{Executive Summary}

On 12 December 2015, the Paris Agreement was adopted by consensus by the 195 Parties to the United Nations Framework Convention on Climate Change (UNFCCC). One year removed from this historic moment, 163 Parties (including the European Union, on behalf of its Member States) have begun detailing the individual commitments that they are expected to make in order to reach the overall mitigation objective of the Agreement, namely that of "holding the increase in the global average temperature to well below $2^{\circ} \mathrm{C}$ above pre-industrial levels", while pursuing efforts to limit the temperature increase to $1.5^{\circ} \mathrm{C}$.

An effective implementation of the 163 Intended Nationally Determined Contributions (INDCs) that have so far been submitted to the UNFCCC (122 of which have been automatically converted to Nationally Determined Contributions, or NDCs, upon their countries' ratification of the Paris Agreement) will necessarily require states to take effective steps to minimize the adverse effects of their response measures but also, where possible, to create positive synergies between climate change mitigation and economic development. This holds particularly true for those countries whose economies are currently highly dependent on a narrow range of carbon-intensive exports, calling for substantial investments and policy interventions aimed at supporting low-carbon innovation, encouraging the transfer of technologies, boosting high-value added sectors and more generally promoting economic diversification.

The extent to which response measures and economic diversification will be capable of operating in a mutually supportive way will depend not only on the design of domestic policies, but also (and perhaps more importantly) on the international trading system, which provides the underlying conditions of competition, market access and market creation that must support a longterm decarbonization of the world economy. As such, this study seeks to improve our understanding of the relationship between response measures, economic diversification and international trade rules, and accordingly identify the positive opportunities that the current proliferation of regional and bilateral trade agreements brings for diversification and climate change mitigation. In doing so, the study explores the following questions: (i) what are the trade-related response measures included in the INDCs/NDCs and how are these measures designed? (ii) What are the implications of these measures on the economic diversification of the states adopting the measures and on other states? (iii) What is the role of free trade agreements in the mitigation of climate change and how are these agreements constructed in a way to allow a space for the implementation of response measures? 


\section{Response measures in the INDCs/NDCs: the (overlooked) importance of trade}

This study represents the first attempt to comprehensively map the 163 INDCs/NDCs submitted by Parties to the UNFCCC in order to identify and categorize response measures that interact with the world trading system. The results are, in a way, unexpected. The occurrence of traderelated measures, including financial and direct trade measures (e.g. taxes, subsidies, carbon pricing mechanisms, FITs, tariffs, import bans) is pervasive throughout the INDCs/NDCs, suggesting the possibility for the climate and trade regimes to substantially interact in the implementation of the Paris Agreement.

On the one hand, some of these interactions may remain hypothetical, in the sense that several measures may, or may not, have implications for trade depending on the instruments and measures adopted at the domestic level to implement them. A majority of the measures that have been mapped as part of the study, particularly green industrial policies and measures taken in the energy sector, appear to fit this description. On the other, the INDCs/NDCs analysed as part of this study have also been found to include a significant number of response measures which are directly relevant for trade. In part as a consequence of the chosen mapping format, these measures broadly fall within two categories identified in the study, namely financial and direct trade measures and green government procurement practices.

\section{Response measures and economic diversification: a mixed picture}

In expanding its analysis of the interactions between climate change mitigation policies and the international trading regime, this study builds upon the mapping of trade-related commitments in the INDCs/NDCs and evaluates such commitments against the long-standing UNFCCC work streams on economic diversification and response measures. While economic diversification had been mainly discussed in the past as a means of minimizing the adverse effects of response measures, the bottom-up nature of the INDCs/NDCs changes this relationship. More specifically, the possibility for developing countries to design their nationally determined contributions in the light of respective national capabilities provides them with an opportunity to enact response measures that promote their own economic diversification and development.

Looking at the current mitigation commitments of UNFCCC Parties, there is certainly scope for the INDCs/NDCs to promote diversification, particularly in the territory of countries where the measures are implemented (for example by incentivizing the transition to a diversified energy mix, fostering innovation through standards and labelling requirements, protecting infant industries through 
green government procurement practices, and so forth). At the same time, it is important to recognize that response measures might also entail cross-border effects (e.g. effects on the economic diversification of other countries), thus emphasizing the importance of coordinated mitigation actions at the regional and international level. The evidence for such cross-border effects is mixed, as the nature and magnitude of their impacts will largely hinge upon the design of domestic policies which are not necessarily reflected in the INDCs/NDCs. In addition, the way in which national implementation is carried out will also likely involve trade-offs.

The incorporation of response measures in free trade agreements: the complementary role of trade

The assessment of the climate-related provisions of current free trade agreements, conducted with the help of Professor Jean Frédéric Morin's TREND Codebook, suggests that the existing international trade regime provides many opportunities to mitigate climate change challenges while supporting economic diversification. First, economic growth that result from the liberalization of trade in goods and services generates useful economic resources to allow the transition from fuel intensive industries into cleaner and less polluting industries. Second, FTAs provide a suitable framework to reduce/eliminate barriers on environmental goods and services, which leads to lowering the cost of green energy technologies. Finally, many FTAs appear to incorporate some of the response measures included in the INDCs/NDCs as a way of strengthening the capacity of states to fulfill their climate change commitments and achieving more stringent and more precise obligations compared to multilateral environmental agreement.

In this context, the most pressing challenge when designing FTAs appears to be that of finding a balance between promoting trade liberalization on the one hand and allowing a policy space for countries to implement their obligations under the UNFCCC on the other, in order to ensure that trade rules positively contribute to, rather than undermine, the overarching objectives of climate change mitigation and economic diversification. 


\section{Introduction}

Global climate change is one of the biggest challenges facing the international community. ${ }^{1}$ As the United Nations Secretary General has explained, "it is the major, overriding environmental issue of our time, and the single greatest challenge facing environmental regulators. It is a growing crisis with economic, health and safety, food production, security, and other dimensions." 2 The main characteristics of climate change are increases in average global temperature; changes in cloud cover and precipitation, particularly over land; melting of ice caps and glaciers and reduced snow cover; and increases in ocean temperatures and ocean acidity. ${ }^{3}$

Both mitigation and adaptation are complementary approaches to reduce risks of climate change impacts over different timescales. The Intergovernmental Panel on Climate Change (IPCC) maintains that well-designed, systematic and cross-sectoral mitigation strategies are more costeffective in cutting emissions than a focus on individual technologies and sectors, with efforts in one sector affecting the need for mitigation in others. In addition, climate change mitigation policies, programmes and actions (which are usually defined in the work of the UNFCCC as "response measures") ${ }^{4}$ intersect with other societal goals, creating the possibility of co-benefits or adverse side effects. If properly managed, such interactions will solidify the basis for undertaking climate action.

In scenarios limiting CO2-eq concentrations under 450 parts per million (ppm) by 2100, global CO2 emissions from the energy supply sector are projected to decline over the next decade and are characterized by reductions of $90 \%$ or more below 2010 levels between 2040 and $2070 .^{5}$ As such, the key measures to achieve climate change mitigation goals are expected to require the efforts of the entire international community, and will include the decarbonization of electricity generation as well as

\footnotetext{
${ }^{1}$ According to the United Nations Framework Convention on Climate Change (UNFCCC), climate change refers to a change in the state of the climate that is "attributed directly or indirectly to human activity that alters the composition of the global atmosphere and that is in addition to natural climate variability observed over comparable time periods". Human activities such as fossil fuel combustion, deforestation resulting from agricultural burning and logging forests, land use or cover changes, and industrial use of artificial chemicals are responsible for releasing GHG emissions into the atmosphere. Intergovernmental Panel on Climate Change, Climate Change 2007: Synthesis Report (UNFCCC 2007) $<$ https://www.ipcc.ch/publications and data/ar4/syr/en/mains1.html> accessed 18 November 2016.

2 Ban-Ki Moon, 'Opening Statement to the High Level Segment of the United Nations Climate Change Conference' (United Nations Climate Change Conference, Pozna, 11 December 2008).

${ }^{3}$ UNFCCC, Climate Change, Impact vulnerabilities and adaptation in developing countries (UNFCCC 2007) 8.

${ }^{4}$ Nama News, 'Response Measures and Their Impacts: an Introduction' (Nama News, 28 July 2015) <http://namanews.org/news/2015/07/28/response-measures-and-their-impacts-an-introduction/> accessed 18 December 2016.

${ }^{5}$ Robert N Stavins and others, 'International Cooperation: Agreements and Instruments' in Ottmar Edenhofer and others (eds) Climate Change 2014: Mitigation of Climate Change. Contribution of Working Group III to the Fifth Assessment Report of the Intergovernmental Panel on Climate Change (Cambridge University Press 2014).
} 
efficiency enhancements and behavioral changes, in order to reduce energy demand compared to baseline scenarios without compromising the development needs of many countries.

From this perspective, the adoption of the Paris Agreement ${ }^{6}$ represents a historic milestone, requiring all Parties "to undertake and communicate ambitious efforts" ${ }^{7}$ with the view to "strengthening the global response to the threat of climate change, in the context of sustainable development and efforts to eradicate poverty". ${ }^{8}$ At the same time, the Agreement recognizes that the implementation of its commitments will require a careful consideration of the specific economic and social needs of developing country Parties (especially those that are most vulnerable to the effects of climate change), ${ }^{9}$ and accordingly emphasizes the urgency of providing these countries with international assistance to support enhanced mitigation and adaptation efforts through capacity building, innovation, technology transfer and access to climate finance. ${ }^{10}$ In particular, the Agreement appears to encourage those Parties that are currently highly dependent on fossil fuel production and carbonintensive exports to seek positive synergies between their response measures and the diversification of their economies, in order to reap mitigation co-benefits through a decoupling of economic growth and GHG emissions, and vice versa. ${ }^{11}$

The concept that economic diversification and response measures can operate in a mutually supportive way is not a new one indeed, and is increasingly being explored by economists, policymakers and academics alike. Most notably, it also provides an important background for the technical work of the UNFCCC, informing the forum and work programme on the impact of the implementation of response measures developed by the two subsidiary bodies to the Convention. ${ }^{12}$ In a legal context, however, it is important to recognize that the ability of countries to simultaneously pursue the two objectives of economic diversification and climate change mitigation will largely depend on a third element, whose role has so far been neglected: international trade. Even though the Paris Agreement itself does not include any trade-related provisions, trade has the potential to play a major role in the implementation of the response measures enshrined by the Parties in their Intended Nationally

\footnotetext{
${ }^{6}$ UNFCCC, 'Report of the Conference of the Parties on its twenty-first session, held in Paris from 30 November to 13 December 2015. Addendum. Part two: Action taken by the Conference of the Parties at its twenty-first session' (29 January 2016) UN Doc FCCC/CP/2015/10/Add.1 [hereinafter Paris Agreement]

${ }^{7}$ ibid, Art. 3.

8 ibid, Art. 2.1.

${ }^{9}$ ibid, preamble.

${ }^{10}$ ibid, Artt. 3, 4.5, 6.6, 7.6, 7.7, 7.13, 9, 10, 11, 13.

11 ibid, Art. 4.7.

12 The idea was first endorsed by the Conference of the Parties to the UNFCCC (COP) at the Cancun Climate Change Conference (COP16) in 2010, which requested the Chairs of the two subsidiary bodies (the Subsidiary Body for Scientific and Technological Advice, or SBSTA, and the Subsidiary Body for Implementation, or SBI) to convene such a forum and develop a related work programme.
} 
Determined Contributions (INDCs) and Nationally Determined Contributions (NDCs) ${ }^{13}$ while creating opportunities for many countries to achieve changes in the structure of their economies. On the one hand, trade policies could be used to promote economic diversification and thereby minimize the adverse effects of response measures for many countries which currently rely on vulnerable economic sectors. ${ }^{14}$ On the other, trade liberalization in low-carbon and environmental goods and services could also create positive synergies between diversification and the overarching goal of a long-term decarbonization of the world economy, particularly by supporting low-carbon innovation, promoting the transfer of technologies, and opening new markets for these exports.

Figure 1: Conceptual model of the interactions between response measures, trade and economic diversification. Response measures can either be trade-supportive or trade-restrictive, and can promote or hinder economic diversification. In turn, diversification in one country can influence international trade flows and support (or negatively impact) mitigation. Most importantly, however, trade rules do not only affect response measures and economic diversification directly, but they also provide the conditions under which response measures and economic diversification can be mutually supportive. Source: authors.

Trade
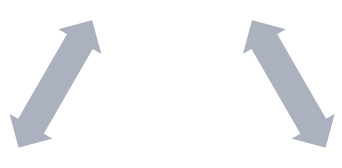

\section{Response}

measures

Economic

diversification

Despite its crucial relevance, the discussion around the relationship between economic diversification, response measures and trade still suffers from a high degree of abstraction, as shown by the conceptual model shown in Figure 1 above. As a consequence, this study seeks to achieve a better understanding of the impacts of the actual response measures contained in the INDCs/NDCs on economic diversification, including their interactions with existing trade rules, in order to build

\footnotetext{
${ }^{13}$ The nationally determined contributions are regulated in Article 4 of the Paris Agreement.

${ }^{14}$ In this context, we refer to the vulnerability of a sector to both climate change and climate change mitigation policies.
} 
mutual supportiveness between the climate and trade regimes while also contributing to broader sustainable development objectives. The analysis is conducted in three parts. First, the study seeks to identify all the response measures contained in the INDCs/NDCs that appear to interact with existing trade rules. Second, the study investigates the potential of the response measures identified in the INDCs/NDCs to have domestic and cross-border effects on economic diversification. Third, the study examines the role of Free Trade Agreements (FTAs) in supporting such a potential through the incorporation of climate-related measures in the international trading system.

This study is divided into four Chapters. Chapter 2 maps trade-related response measures across the 163 INDCs and NDCs submitted by the Parties to the UNFCCC as part of their commitments under the Paris Agreement. Chapter 3 builds upon the mapping examined in Chapter 2 and evaluates country commitments against the long-standing UNFCCC work streams on economic diversification and response measures. Finally, Chapter 4 provides an analysis of relevant provisions in existing trade agreements which can be found to support the implementation of response measures, whether by incorporating climate related measures into trade agreements or by including general and specific exceptions to allow the implementation of climate change agreements. The results of the mapping included in Chapter 2 are included in Annexes 1 and 2. 


\section{Mapping trade-related response measures in INDCs/NDCs}

\subsection{Introduction and scope of the mapping}

This Chapter maps 163 INDCs and NDCs submitted by the Parties to the UNFCCC as part of their commitments under the Paris Agreement. The agreement was adopted at the $21^{\text {st }}$ Conference of the Parties to the UNFCCC on 12 December 2015 and entered into force on 4 November 2016, on the thirtieth day after the date on which both requirements laid down in its Article 21 had been met. ${ }^{15}$

The objective of the mapping is to identify and categorize response measures contained in the INDCs or NDCs which interact with the world trading system. From this perspective, three preliminary considerations shall be borne in mind. First of all, for the purpose and scope of the exercise, an interaction can be either actual or hypothetical. Actual interactions occur whenever response measures contained in a specific INDC/NDC refers directly to an action which is trade-relevant; in this case, the commitment in question explicitly involves a trade-related measure as a means of achieving the objectives of the Paris Agreement:

\section{"By 2020, establish efficiency standards \\ for the importation of all vehicles and appliances."}

(INDC of Antigua and Barbuda, p.2)

By contrast, hypothetical interactions occur whenever an intended outcome, rather than a concrete measure or action, is set. Outcomes may, or may not, have implications for trade depending on the instruments and measures adopted at the domestic level to implement them. For example, a commitment on the part of a country to increase its installed capacity of solar power would not necessarily be translated into a domestic policy which establishes a domestic content requirement for the purchase of photovoltaic (PVs) modules (trade-restrictive) or eliminates tariffs on such goods (trade-supportive). An overview of the mapping results indeed suggests that many of the interactions between trade and climate change policies in the INDCs/NDCs are of this second type, owing to the fact that, in most cases, the listed response measures have yet to be designed and/or implemented at the national level.

${ }^{15}$ On 5 October 2016, 10 countries (Austria, Bolivia, Canada, France, Germany, Hungary, Malta, Nepal, Portugal and Slovakia) deposited their instruments of ratification, thereby fulfilling the second requirement set in Article 21 (the Parties that have ratified the agreement must account for at least 55 per cent of total global greenhouse gas emissions). The first requirement (mandating that at least 55 Parties must have ratified the agreement for it to enter into force) had been met on 21 September 2016, when 31 additional countries formally deposited their instruments during a special event held at the United Nations Headquarters in New York. 
Secondly, the intented contributions contained in the INDCs/NDCs can result in synergies between climate change policy and the international trading regime or, instead, run contrary to the standing rules of the World Trade Organization (WTO), the provisions of relevant Regional Trade Agreements (RTAs), bilateral investment treaties (BITs), and so forth. Synergies occur whenever trade openness can enhance and be beneficial to countries' efforts to mitigate climate change, for example by reducing barriers to trade for environmental goods and services or more generally facilitating technology transfer. Clashes, on the other hand, are bound to emerge whenever domestic measures modify the conditions of competition and thereby have an impact on international trade, as in the case of regulations, which discriminate like products on the basis of process and production methods (PPMs), introduce trade restrictions to allievate competitiveness concerns, or seek to protect infant low-carbon industries from competition. ${ }^{16}$ Both trade-restrictive and trade-supportive response measures are covered by the exercise.

Finally, response measures relating to agriculture, land use, land-use change and forestry (LULUCF), water and waste fall beyond the scope of the exercise, and are not included in the country summaries. In addition, measures relating to the transportation and building sectors are included in the mapping only insofar as they appear to be potentially trade-related.

\subsection{Methodology and mapping format}

Negotiations under the UNFCCC Secretariat did not yield a common format for the submission of INDCs/NDCs. Consequently, there exists an extreme diversity of structure, wording, and degree of specificity in the countries' commitments. As such, the format adopted for this mapping study was developed ex novo, utilizing a country-by-country analysis based on a set of six categories. These categories were identified after a preliminary examination of the INDCs/NDCs, so as to ensure the inclusion of all trade-related response measures within the chosen format. Every country summary starts with a box which contains the overarching targets expressed by that country and then maps commitments according to the classification outlined below:

- Measures related to the energy sector. This category applies to any response measure relating to the energy industry and electricity generation, with the exception of specific financial contributions such as subsidies or taxes (which are listed in a separate

\footnotetext{
${ }^{16}$ See for example IImi Granoff, 'Trade Implications of Climate Policy after the Paris Outcome' (Commonwealth Trade Hot Topics Issue 130, 2016) <http://www.oecd-ilibrary.org/fr/commonwealth/trade/trade-implications-ofclimate-policy-after-the-paris-outcome 5jlwz7lt4k9q-en> accessed 12 October 2016; See also, Joost Pauwelyn, 'Carbon Leakage Measures and Border Tax Adjustments Under WTO Law' in Geert Van Calster and Denise Prévost (eds) Research Handbook on Environment, Health and WTO (Cheltenham, Northampton: Edward Elgar, 2013).
} 
category). Examples include measures seeking to increase the share of renewable sources of energy in the energy mix of countries, or phase out polluting power plants, or modernize the national electricity grid.

- Green industrial policies. This category includes any measure that supports lowcarbon development, seeks to reduce emissions from the industrial sector and improve efficiency, and facilitates the uptake of new technologies. Similar to the first category, financial measures implemented as part of green industrial policy are listed separately.

- Green government procurement. This category encompasses any measure by which the public authority of the interested country seeks to procure low-carbon goods and services in order to contribute to emissions reduction and/or provide incentives for the development of new technologies and products. It does not cover measures, such as Feed-in-Tariffs (FITs), where government procurement is undertaken with a view to commercial resale, and it also excludes any procurement which entails subsequent distribution to private households. Examples include procurement of energy efficient lightbulbs for government buildings or street lighting, retrofitting, and modernization of aircraft or public transport fleets.

- Financial and direct trade measures. This category covers any measure which restricts trade, imposes a financial burden or provides a direct or indirect monetary contribution in order to promote the investment in and production or consumption of renewable sources of energy (i.e. phasing out fossil fuel subsidies, introducing a domestic carbon tax, restricing imports of certain goods). A subcategory is adopted to highlight financial measures related to environmental goods and services (i.e. domestic content requirements for PV modules, tax incentives for the importation of lowemissions vehicles), which continue to represent a hotly debated topic under the Doha Development Round of the WTO. To be included in the subcategory, a measure must specifically mention the environmental good or service in question, not merely refer to the general promotion of renewable energy projects or technologies.

- International cooperation. This category includes any bilateral, regional or international contribution or request of contribution towards the implementation of the INDCs/NDCs in developing or Least Developed Countries (LDCs). Examples include access to sources of climate finance, establishment of international market mechanisms to sell carbon credits, technology transfer, and capacity building. 
This mapping study adhered to the textual formulation of the response measures included in the INDCs/NDCs. For purposes of clarity and consistency, some expressions were changed (in particular, commitments beginning with a verb in their infinitive form were edited and the verb in question converted to a noun), ${ }^{17}$ while commitments contained in longer sentences were isolated from the context in order to remove discursive digressions which were not relevant to the assigned mandate. Every effort was made to ensure conformity to the original text.

In order to map the twenty-one INDCs/NDCs that were neither originally written in the English language nor accompanied by an official or unofficial translation provided by the submitting Party, an original translation was produced by the authors, as indicated in each country summary. ${ }^{18}$ For these INDCs/NDCs, a country summary in the original language of each submission (with the exception of Iraq) is also provided in an Annex.

\section{3. $\quad$ Findings}

This section describes the main findings of the mapping. In doing so, it focuses on four main topics, covering the full range of UNFCCC Parties' response measures and making reference to the six categories identified in the mapping format. In section 2.3.2., we present a general overview of the similarities and differences in the scope, structure, and wording of the INDCs/NDCs. In section 2.3.3., we identify a list of proposed response measures that appear to be directly relevant for the international trading regime and which mainly consist of financial and direct trade measures and green government procurement practices. In section 2.3.4., we analyse the possibility that other commitments contained in the INDCs/NDCs (broadly listed in the study under the 'energy sector and emissions reduction' and 'green industrial policies' categories) also lead to interactions with international trade, depending on the domestic measures enacted to implement them. Finally, in section 2.3.5., we discuss commitments to international cooperation on climate change, focusing on climate finance, use of carbon credits, international market mechanisms, technology transfer and any other means necessary for the implementation of response measures.

\subsubsection{General overview of the INDCs/NDCs: scope, structure, and wording}

As explained in Chapter 2.2., and despite the guidance provided by the COP in Decision 1/CP.20 ('Lima Call for Climate Action'), no uniform template was provided to UNFCCC Parties for the

\footnotetext{
${ }^{17}$ For examples, commitments starting with the verb "promoting" were re-phrased as "promotion of".

${ }^{18}$ In these country summaries, the word "translation" is put in brackets next to the name of the submitting Party, together with an asterisk $\left(^{*}\right)$.
} 
submissions of their INDCs/NDCs. This obviously gave countries significant leeway in drafting their commitments, which resulted in several glaring inconsistencies in terms of structure, style and wording. At the same time, it is possible to identify some common features, mainly as a consequence of the information included in the Lima Call for Climate Action but also thanks to unofficial guidance documents provided by non-governmental organizations and international networks of stakeholders. ${ }^{19}$

First, most INDCs/NDCs indicate the intended GHG and non-GHG targets to be achieved during an identified time period. In formulating their GHG targets, many countries used a percentage change in future emissions levels (either economy-wide, per capita, or per unit of GDP), while others only indicated an absolute reduction in GHG emissions. These changes are usually expressed against either a baseline year (1990 and 2005 are the most common) or a business as usual scenario of uncontrolled development (BAU). Non-GHG targets, by contrast, are extremely diversified, and cannot be reduced into predefined categories.

Second, and beyond quantifiable information on reference points, time frames, and periods of implementation, many INDCs/NDCs also include sections that reflect Decision 1/CP.20 guidelines on topics such as, inter alia: (i) scope and coverage; (ii) planning processes, (iii) assumptions and methodological approaches; and (iv) how the parties consider that their INDCs/NDCs are fair and ambitious, in light of their national circumstances.

Lastly, the INDCs/NDCs of most developing country Parties follow the guidelines provided in section 16.5 of Decision 1/CP.20 and allocate their targets into two distinct categories, one unconditional, which countries are committing to achieve unilaterally using the state domestic efforts, and the second conditional on the provision of external support (finance, technology development and transfer, and capacity-building). ${ }^{20}$ For example:

\footnotetext{
"The Republic of Colombia commits to reduce its greenhouse gas emissions by $20 \%$ with respect to the projected BAU by 2030 . Subject to the provision of
}

\footnotetext{
${ }^{19}$ See for example CDKN and Ricardo-AEA, 'A Guide to INDCs' (2 ${ }^{\text {nd }}$ Edition, May 2015) <http://cdkn.org/wpcontent/uploads/2015/04/CDKN-Guide-to-INDCs-Revised-May2015.pdf> accessed 19 October 2016; Kelly Levin and others, Designing and Preparing Intended Nationally Determined Contributions (WRI: Washington DC 2015) < http://www.wri.org/sites/default/files/designing-preparing-indcs-report.pdf> accessed 19 October 2016; and Niklas Höhne, Christian Ellermann and Hanna Fekete, 'Process Guidance for Intended Nationally Determined Contributions' (International Partnership on Mitigation and MRV Knowledge Product, November 2014) < https://mitigationpartnership.net/sites/default/files/ipmm 2014 process guidance for intended nationally deter mined contributions indcs.pdf> accessed 19 October 2016.

${ }^{20}$ UNFCCC, 'Report of the Conference of the Parties on its twentieth session, held in Lima from 1 to 14 December 2014. Action taken by the Conference of the Parties at its twentieth session' (2 February 2015) FCCC/CP/2014/10/Add.1.
} 
international support, Colombia could increase its ambition from $20 \%$ reduction with respect to BAU to $30 \%$ with respect to BAU by $2030 . "$

(INDC of Colombia, p. 2, translation)

Notwithstanding these similarities, it seems clear that countries largely differ on the approach they adopted to design the content of their response measures, and in this context a major divide can be drawn between developed and developing country Parties. Developed countries in particular (e.g. United States, Russia, Japan), together with the European Union, used very generic wording, and their INDCs/NDCs are relatively shorter compared to other countries:

\section{In the energy sector, Japan commits to the "expansion of renewable energy introduction to the maximum extent possible."}

(INDC of Japan, p. 15)

On the other hand, developing countries have longer INDCs/NDCs (up to 35-40 pages) and more detailed and specific commitments. Their contributions are more elaborate in terms of both sectoral outcomes and means that will be used to achieve the outcomes, and they often include financial or direct trade measures. For instance:

In the energy sector, "Ghana intends to scale up renewable energy penetration by $10 \%$ by $2030 . "$ (outcome)

(INDC of Ghana, p.3)

"Phasing out fossil fuel subsidies and setting up feed-in-tariffs for renewable energy technologies." (actions)

(INDC of Ghana, p. 11, annex 1)

In addition, some developing countries like Kuwait, Togo, and Panama, referred to specific provisions in their domestic laws to explain the details of their actions:

"[...] Article (122) and (123) of the Environment Protection Law 42/2014 mentioned the need to use energy-saving systems in the new state facilities. Also the law prevents importing any hardware or equipment that does not match the specifications of energy conservation."

(INDC of Kuwait, p.6, translation)

Finally, in contrast with developed countries' INDCs/NDCs, most developing country Parties: (i) include a list of intended projects to be implemented in the future and the cost of such implementation; 
(ii) stipulate their needs in terms of finance, capacity building, foreign direct investment, and technology transfer; and (iii) promote the possibility of using international market-based mechanisms to achieve their targets through carbon crediting, within and beyond existing instruments such as the Clean Development Mechanism (CDM) and the Joint Implementation (JI) regime. For example, according to the INDC of Jordan:

The estimated cost to reach the $14 \%$ target is totaling USD $5,700,000,000$ from which Government of Jordan has already secured USD 542,750,000 by its own means to meet the unconditional target; which means the Country is in need of USD $5,157,250,000$ to fulfill its conditional target."

$($ pp.1-2)

\subsubsection{Actual interactions between INDCs/NDCs and trade}

The INDCs/NDCs analysed as part of this study have been found to include a significant number of response measures which are directly relevant for trade, regardless of the structure and scope of the domestic instrument adopted to implement them. In part as a consequence of the chosen mapping format, these measures broadly fall within two categories identified in the study, namely: (i) financial and direct trade measures; and (ii) green government procurement.

\subsubsection{Financial and direct trade measures}

UNFCCC Parties provide a variety of financial and direct trade measures to achieve their intended targets specified in the INDCs/NDCs, including, inter alia, taxes, subsidies, carbon pricing mechanisms, FITs and Renewable Portfolio Standards (RPS), tariffs, import bans, and investments in $R \& D$. As described in section 2.2., these measures can interact with trade due to their effects on international competition (in the case of taxes, subsidies and investments in R\&D) or through the removal/establishment of barriers to trade (in the case of import bans and tariffs). A non-exhaustive list is provided below to highlight such a broad spectrum of commitments, which can be trade-restrictive or trade-supportive depending on the structure and scope of the domestic provisions enacted to implement them.

- Taxes. Tax exemptions on mass transit vehicles and 4T motorcycles and parts (Benin), on energy efficient appliances and products (Brunei Darussalam), for the development of renewable energy (Côte d'Ivoire), for maritime transport (Turkey). Tax reductions for use of solar panels and solar water heaters (Grenada), for electric and hybrid vehicles (Korea, Saint Lucia). Tax incentives for the investment in alternative vehicles and fuels such as compressed 
natural gas, liquid petroleum gas, ethanol, natural gas, hybrid and electric (Barbados). Preferential taxation policies for promoting the development of new energy and to improve mechanisms of pricing, grid access and procurement mechanisms for solar, wind and hydro power (China). Introduction of a carbon tax (Armenia, Chile, India, South Africa). Introduction of taxation on diesel and gasoline (Grenada), linked to mileage per gallon and engine capacity of cars (The Bahamas).

- Subsidies. Provision of subsidies for renewable energy (Afghanistan, Burkina Faso, Guatemala), for private residences to promote sustainable architectural structures (Burkina Faso), targeted subsidies for retrofits (Rwanda). Removal of subsidies on fossil fuel (Ethiopia, Ghana, India, Nigeria, Sierra Leone), gradual reduction of subsidies on electricity (Kuwait, Morocco).

- Import bans. Import ban on vehicles older than 3 years (Gabonese republic), on incandescent bulbs and inefficient devices (Venezuela), on old cars (Djibouti), on hardware or equipment that does not match domestic standards (Kuwait).

- Tariffs and import duties. Custom tariffs on the importation of motor vehicles (Cook Islands). Removal of tariffs on environmental goods and services, such as renewable energy products (Guyana, Suriname), fuel-efficient and alternative energy vehicles (Dominica, Saint Lucia, Saint Vincent and the Grenadines, The Bahamas).

- Market-based mechanisms. Introduction or expansion of domestic carbon emissions trading schemes or other market-based mechanisms (China, Costa Rica, Dominica, Egypt, Gabon, Panama, Saint Lucia, Samoa, Sierra Leone, Tunisia, Viet Nam) Feed-In-Tariffs or Renewable Portfolio Standards (Cameroon, Ghana, India, Mozambique, Malaysia, Thailand, Sierra Leone).

\subsubsection{Green government procurement}

Green government procurement practices, although not widely included in the INDCs/NDCs, can also play an important role in stimulating the demand for environmental goods and services and thereby act as indirect support to innovation. Furthermore, depending on the conditions of their implementation, they can be powerful instrument of technology transfer or, by contrast, be used in a trade-restrictive way as a form of protection for low-carbon domestic industries. With respect to the specific measures mapped in this study, green government procurement covers three main areas: (i) transportation; (ii) public buildings; and (iii) public lighting. 
- Public transportation. Green government procurement commitments relating to public transport focus on the improvement of fleet composition through the purchase of more efficient, hybrid or other alternative fuel vehicles (Cabo Verde, Costa Rica, Dominica, Lesotho, Mauritius, Monaco, Papua New Guinea, United Arab Emirates), or modern aircrafts (Equatorial Guinea).

- Public buildings. Energy efficiency or retrofit programs for public buildings (Bahrain, BosniaHerzegovina, Djibouti, Grenada, Kuwait, Palau, Senegal). Solar rooftop programs (Bangladesh, Djibouti). Purchase obligation of local and energy-efficient construction materials (Burkina Faso).

- Public lighting. Installation of low-carbon technology in street lighting (Cuba, Saint Vincent and the Grenadines, Senegal).

\subsubsection{Hypothetical interactions between the INDCs/NDCs and trade}

As discussed in section 2.1., a specific response measure contained in the INDCs/NDCs can be, per se, trade neutral, but become trade-relevant whenever the policy enacted at the domestic level interacts with the existing complex of rules governing international trade and investment. A majority of the measures that have been mapped as part of the study, particularly under the two categories identified as 'energy sector and emissions reduction' and 'green industrial policies', appear to fit this description. Three sets of motivations, which in turn correspond to three different ways in which the response measures themselves are presented, can be advanced to explain such results.

First, many Parties have provided information on sectoral targets or mitigation outcomes rather than, or in addition to, proper mitigation actions. It can be observed that this type of contribution occurs mainly in the energy sector, which is often addressed in the INDCs/NDCs as an overall sectoral target that may (or may not) be then specified through Nationally Appropriate Mitigation Actions (NAMAs), sectoral strategies and policies, and specific projects. ${ }^{21}$ Two examples of commitments expressed as

${ }^{21}$ It shall be noted that specific projects in the energy sector (e.g. renewable energy projects, conversion of existing power plants) are almost entirely absent from the INDCs/NDCs of developed country Parties, but frequently mentioned by developing country Parties (and particularly by LDCs and small developing countries). Such a discrepancy can arguably be explained by the different size of these economies (which allows a much finer examination of the structure and composition of their energy sector), but also by the specific emphasis put 
an outcome are the following, which can be found uniformly, although in different forms and levels of ambition, across a number of country summaries:

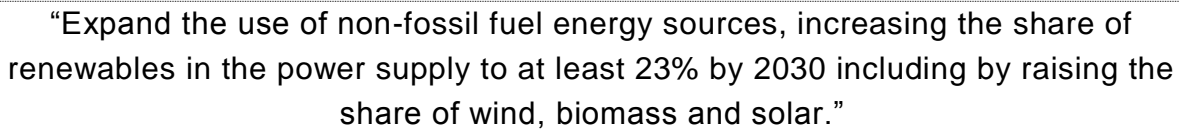

"Expand the use of non-fossil fuel energy sources, increasing the share of renewables in the power supply to at least $23 \%$ by 2030 including by raising the share of wind, biomass and solar."

(INDC of Brazil, p.3)

\begin{abstract}
"The Power Development Plan sets a target to achieve a $20 \%$ share of power generation from renewable sources in 2036. The Alternative Energy Development Plan" aims to achieve a $30 \%$ share of renewable energy in the total final energy consumption in 2036. The Energy Efficiency Plan plans to reduce the country's energy intensity by $30 \%$ below the 2010 level in 2036."
\end{abstract}

(INDC of Thailand, p.3)

Secondly, even when response measures are formulated as actions, the use of vague language poses obstacles to the identification of the policies that will in practice underpin that action. This appears to be one of the most common occurrences in the INDCs/NDCs, with no particular distinction between targeted sectors. These two illustrations of vaguely-worded actions (mapped in the 'energy sector and emissions reduction' and 'green industrial policies' categories, respectively) suggest that countries have often adopted general commitments to 'provide', 'promote', 'introduce', 'support', 'develop' or 'encourage' low-carbon technologies or projects, to name but a few, without discussing the details of the proposed policies:

"Special programmes to promote small and mini hydel projects, new and efficient designs of water mills have been introduced for electrification of remote villages."

(INDC of India, p.9)

"Promotion of low-carbon development of service industry, actively developing lowcarbon business, tourism and food service and vigorously promoting service industries to conserve energy and reduce carbon emissions."

(INDC of China, p.9, translation)

Finally, explicit actions implemented at the national level might interact with the world trading system only indirectly, for example through their impact on the competitiveness of domestic firms or by acting as forms of 'indirect expropriation' of foreign investment. In these cases, while the actions in question would unquestionably have effects on trade flows, they would not necessarily clash with

by developing countries on the need to link climate change mitigation with broader sustainable development concerns, such as access to energy and economic development. 
existing trade rules, unless the interested country enacted competitiveness provisions to level the playing field between imports and domestic products. Actions mapped in the 'green industrial policies' category, which frequently include measures such as, inter alia, energy efficiency or GHG emissions standards for key industrial sectors, regulation of PPMs, demand-side management provisions, and building codes, provide the clearest example of this type of response measures:

"Research and formulation of greenhouse gas emission standards for key industries."

(INDC of China, p.8, translation)

"Revision of the building code to improve energy performance by standards of construction and renovation, and a certification process."

(INDC of Cameroon, p. 6, translation)

\subsubsection{International cooperation on climate change}

The final aspect of this mapping concerns the trade dimension of country commitments in the field of international cooperation on climate change. Indeed, nearly all INDCs/NDCs devote at least some space to discuss the need to support developing country Parties in decoupling economic growth from carbon emissions while pursuing poverty reduction, trade and investment opportunities, job creation, and access to basic services. Furthermore, as discussed in section 2.2., developing countries (particularly LDCs and SIDS) have in many cases made their entire range of contributions, or at least an increased level of ambition, conditional upon such support. Consequently, topics such as market-based mitigation, climate finance, and South-South cooperation, all of which have implications for trade-led development, can be found to represent a major focus of both developed and developing countries' submissions. Although the details and language adopted vary greatly, the INDCs/NDCs generally appear to be more coherent and consistent in this area than in those examined above.

First of all, while a number of Parties explicitly stated that they do not intend to purchase carbon credits under existing (CDM, JI) or emerging mechanisms (presumably, those identified in the Paris Agreement after most intended contributions had already been communicated) ${ }^{22}$ in order to meet their GHG targets, the INDCs/NDCs nonetheless reveal a widely shared commitment to the use of international market-based instruments as a means of mobilizing resources for developing countries

\footnotetext{
${ }^{22}$ Most notably the European Union, Russia and the United States.
} 
and thereby contribute to cost- effective implementation of low-carbon development pathways. ${ }^{23} \mathrm{At}$ the same time, there appears to be widespread concern about the need to promote transparency and develop effective Monitoring, Reporting and Verification (MRV) systems as part of such mechanisms, with the goal of ensuring their environmental integrity and avoiding double counting.

Secondly, a broader focus on the importance of climate finance is evident for both developed and developing countries, but is particularly emphasized by the latter as a critical means to reach wider sustainable development objectives. In addition, the proposed strategies and channels of funding mapped in this study often go beyond market-based instruments to encompass grant-based funding, loan financing mechanisms and traditional development aid, ${ }^{24}$ but also increased involvement of the private sector, including through domestic regulatory interventions aimed at strengthening intellectual property rights (IPRs) and more generally encouraging foreign direct investment (FDI).

Lastly, an emerging trend towards increased regional cooperation on climate change transpires from many INDCs/NDCs. From this perspective, three main themes can be identified: (i) integration of sub-regional energy markets and electricity grids, highlighted by a number of African countries (e.g. Cameroon, Chad, Côte d'Ivoire and Djibouti); (ii) further economic integration and cooperation between traditional trading partners, such as in the case of Canada and the United States; and (iii) accentuation of the importance of South-South cooperation, to be supported through bilateral and multilateral agreements for the mobilization of resources and the facilitation of technology transfer and capacity building (most notably promoted by Brazil, Brunei Darussalam, China, and Colombia).

\footnotetext{
${ }^{23}$ It shall be noted that an exception is represented by Bolivia, Cuba and Venezuela, which remain explicitly opposed to the use of market-based mechanisms under the UNFCCC.

${ }^{24}$ Institutions and mechanisms explicitly mentioned by countries are extremely diversified, but can be found to include the Green Climate Fund (GCF), the Global Environment Facility (GEF), the World Bank and the United Nations Development Programme (UNDP), as well as a number of multilateral and regional development banks.
} 


\section{The interplay between economic diversification and response measures in the INDCs/NDCs}

\subsection{Introduction}

This Chapter seeks to expand our analysis of the interactions between climate change mitigation policies and the international trading regime by discussing the synergies and tensions emerging in this field through the lenses provided by the concept of economic diversification. More specifically, the Chapter builds upon the mapping of trade-related commitments in the INDCs/NDCs examined in Chapter 2 and evaluates such commitments against the long-standing UNFCCC work streams on economic diversification and response measures. By doing so, the Chapter also aims to identify the potential for the measures contained in the INDCs/NDCs to positively contribute to the goal of economic diversification, and accordingly argues that an integrated assessment of the extent to which the trade and climate regimes are currently mutually supportive with respect to this goal will be necessary for such a potential to be fulfilled.

\subsection{Economic diversification in the UNFCCC work streams}

\subsubsection{A definition of economic diversification in the context of climate change}

The notion of economic diversification has always been linked to the need to achieve sustainable economic growth through reduced vulnerability to produce price fluctuations on world markets, increased resilience to economic conditions, and job creation. ${ }^{25}$ In this sense, economic diversification can be described as a process or strategy in which some combination of the following occurs:

- diversification of markets for exports;

- diversification of income sources away from domestic economic activities;

- diversification of products and/or practices within an economic activity. ${ }^{26}$

\footnotetext{
${ }^{25}$ Hugh O Nourse, Regional Economics: a Study in the Economic Structure, Stability, and Growth of Regions (McGraw-Hill 1968). See also UNFCCC, 'The concept of economic diversification in the context of response measures. Technical Paper by the Secretariat' (6 May 2016) UN Doc FCCC/TP/2016/3, 7.

26 UNFCCC, The Nine Work Areas of the Nairobi Work Programme. 9: Economic Diversification. <http://unfccc.int/3994.php> accessed 18 November 2016.
} 
At the same time, economic diversification has come to be closely associated with the concept of innovation, and more precisely with the production of "high-technology, high-value added" goods and services. ${ }^{27}$

Economic diversification has been discussed under the umbrella of the UNFCCC at least since 2000. ${ }^{28}$ Over time, such a concept has been understood as referring to at least two of the Convention's work streams, and namely: (i) within the framework of the Nairobi Work Programme, ${ }^{29}$ which emphasises the potential of diversification to promote adaptation to climate change by reducing the reliance of developing countries on vulnerable economic sectors; and (ii) in the context of response measures, as a means of reducing the adverse economic impacts arising from their implementation (especially in the case of measures having cross-border effects). ${ }^{30}$ Whilst the focus on adaptation falls beyond the scope of this study, we will particularly analyse the interplay between economic diversification and response measures, in the light of the adoption of the Paris Agreement but also, more specifically, with respect to subsequent discussions among the Parties on both the domestic and cross-border effects of climate change mitigation policies on economic development.

From this perspective, three preliminary considerations shall be put forward. First, economic diversification in the context of climate change needs to be seen as essentially relating to developing countries, and in particular to those countries that are more vulnerable to the impact of a low-carbon transition because of their dependence on a narrow range of exports, such as:

- fossil fuel exporting countries;

- countries exporting energy-intensive, trade-exposed goods (e.g. steel, cement, chemicals, pulp and so forth) and consumer goods subject to standards and labelling requirements;

- tourism-dependent countries such as SIDS and LCDs;

- large exporters of agricultural commodities. ${ }^{31}$

\footnotetext{
${ }^{27}$ Paul G Hare, 'Institutions and Diversification of the Economies in Transition' in Rob Vos and Malinka Koparanova (eds) Globalization and Economic Diversification (Bloomsbury Academic 2011) 24.

${ }^{28}$ Economic diversification in the context of the UNFCCC was first mentioned during a workshop organized by the Subsidiary Body for Scientific and Technological Advice (SBSTA) and the Subsidiary Body for Implementation (SBI) on the consequences of the implementation of response measures. See UNFCCC, 'Implementation of Article 4.8 and 4.9 of the Convention' (10 May 2000) UN Doc FCCC/SB/2000/2, 6-8.

${ }^{29}$ See UNFCCC, 'Nairobi Work Programme' <https://www3.unfccc.int/pls/apex/f?p=333:1:4253476579711040> accessed 19 November 2016).

${ }^{30}$ UNFCCC, 'Information note to facilitate deliberations on potential environmental, economic and social consequences, including spillover effects, of implementing tools, policies, measures and methodologies available to Annex I Parties, taking into account the submissions and views contained in documents FCCC/KP/AWG/2008/MISC.5, FCCC/KP/AWG/2009/MISC.4 and other relevant documents' (16 March 2009) UN Doc FCCC/KP/AWG/2009/INF.3, 4.

${ }^{31}$ ibid 22.
} 
Second, economic diversification shall not be considered as a mere by-product of economic development, not only because of the risks posed by climate change to the growth of developing countries characterized by high degrees of concentration but also, at least in part, when considering the opportunities and benefits of fostering early changes in the productive structures of these economies. $^{32}$ On the contrary, economic diversification in the context of climate change goes beyond addressing the impact of response measures to pursue mitigation co-benefits ${ }^{33}$ and wider sustainable development objectives. This is emphasized by, inter alia, the definition in May 2016 of a three-year work programme under the UNFCCC which identifies diversification as a crucial strategy to progress to a low-carbon economy, facilitate a just transition of the workforce and create decent work and quality jobs. ${ }^{34}$ Third, whilst economic diversification ultimately needs to be undertaken at the national level, it is important to realize that international cooperation in the fields of trade liberalization, access to finance, and preferential market access, plays a major facilitative role in the process, for example by reducing non-domestic barriers to diversification (i.e. trade barriers), encouraging foreign direct investment in non-traditional sectors, and promoting the transfer of technologies. ${ }^{35}$

This last point is particularly relevant for our analysis, in that it explains why economic diversification represents a useful framing device for exploring the linkages between the climate and trade regimes and identifying the potential for the trade system to contribute to climate change mitigation. In other words, from a legal perspective a low-carbon transition will require mutually supportive climate and trade regimes, as evidenced by the results of the mapping of INDC/NDC response measures contained in Chapter 2. In turn, international trade rules will be able to promote mitigation only insofar as they can enable economic diversification through innovation and adoption of low-carbon technologies in developing countries.

\subsection{Potential impacts of response measures on economic diversification}

\footnotetext{
32 Jodie Keane, 'Diversifying Exports in the Context of Climate Change' (April 2011) Overseas Development Institute Background Paper, $2<$ https://www.odi.org/sites/odi.org.uk/files/odi-assets/publications-opinionfiles/7090.pdf> accessed 19 September 2016

${ }^{33}$ See Art. 4.7 of the Paris Agreement.

${ }^{34}$ UNFCCC, 'Improved Forum and Work Programme. Revised Draft Conclusions Proposed by the Chairs' (26 May 2016) UN Doc FCCC/SB/2016/L.2/Rev.1.

${ }^{35}$ During the 'Workshop on views and experiences on economic diversification and transformation and on a just transition of the workforce and the creation of decent work and quality jobs', held in Doha from 2 to 4 October 2016 and organized by the Secretariat upon request by the SBSTA and the SBI, it was emphasized that "trade and economic diversification are linked through the global value chain". See UNFCCC, 'Report by the Chairs of the Subsidiary Bodies' (28 October 2016) UN Doc FCCC/SB/2016/INF.2, 7.
} 
The term "response measures" is not explicitly defined in the text of the UNFCCC, even though it is included in both Article 4.8 of the UNFCCC and Article 4.15 of the Paris Agreement, in the context of the need to take into consideration the concerns of developing country Parties about the adverse economic impacts arising from the implementation of emissions reduction activities. A non-technical concept adopted in the work of the two subsidiary bodies to the Convention, response measures mainly refer to every process, policy or programme undertaken by the Parties to mitigate and reduce GHG emissions. With a specific emphasis on the Paris Agreement, it can further be argued that the reference to response measures contained in Article 4 (which codifies the INDC/NDC process in the treaty text) clarifies how such measures should be seen as including the full range of commitments expressed by countries in their INDCs/NDCs. As shown by the mapping study conducted in Chapter 2 , these commitments may take a variety of forms and pertain to different economic sectors, but can all be associated under the overarching notion of "activities that contribute to climate change mitigation". ${ }^{36}$ This section particularly analyses what the implementation of response measures exactly entails in terms of their impacts on vulnerable economies, whilst Section 3.4. will discuss the implications of the implementation of response measures for economic diversification, with an eye on the evolution of this relationship since the adoption of the UNFCCC.

As discussed in the previous section, the adverse impacts arising from the implementation of response measures are strictly related to the degree of economic diversification experienced by the affected country, and might entail domestic as well as cross-border effects. Fossil-fuel producing countries, countries exporting carbon-intensive goods and services, and tourism-dependent countries are particularly bound to be impacted, regardless of their exposure to the physical effects of climate change, due to structural changes in the demand for, and prices of, the products and services which comprise the bulk of their exports, as well as in the wider regulatory environment. ${ }^{37}$ For the purposes of this study, these impacts can be grouped into five categories:

- First, climate and energy policies in energy importing countries, (e.g. domestic carbon taxes, cap-and-trade schemes and subsidies for renewable energy technology producers) are probably going to result in a loss of market share for foreign exporters of fossil fuels (but also for foreign competitors in the production of renewable energy technology, for example). ${ }^{38}$

\footnotetext{
${ }^{36}$ It should be noted that the concept of response measures is broader than that of mitigation, and includes the area of adaptation (which falls beyond the scope of this study).

${ }^{37}$ During the UNFCCC Doha Workshop (n 31), a representative of the World Bank Group referred to this concept as 'transition risk'.

${ }^{38}$ See for example Philip Bagnoli and others, The Incidence of Carbon Pricing: Norway, Russia and the Middle East (2008) OECD Economic Studies No.44, 2008/1 <http://www.oecd.org/eco/42505369.pdf> accessed 19 November 2016.
} 
- Second, border tax adjustments that target carbon-intensive products might cause a similar loss of market share in carbon-intensive export sectors or require importers to "participate in emissions trading schemes and purchase emissions allowances according to the carbon content of products they supply". ${ }^{39}$

- Third, higher technical standards and labelling requirements enacted in both importing and exporting countries might lead to a loss of competiveness, thereby impacting non-domestic firms as well as domestic firms that don't have the financial and/or technical capacity to adapt to the new regulations, respectively.

- Fourth, possible structural shifts in consumers and/or investors' preferences, coupled with the adoption of disruptive business models and low-carbon technologies, might further drive down competitiveness and cause unemployment due to the demand of new, highlyskilled work force and labour-market rigidities.

- Fifth, plurilateral or multilateral efforts, such as international carbon taxes or levies, might impact revenues and trade flows in certain sectors of the economy, such as maritime transport, air-freight, and tourism. ${ }^{40}$

At the same time, it should be noted that the ongoing discussions around the issue of response measures have profoundly changed since the adoption of the UNFCCC. On the one hand, UNFCCC debates on the need to minimize the adverse impacts of response measures have had to bypass the initial emphasis on the obligation for developed countries to provide compensation for the cross-border effects of their mitigation politicies (something which continues to represent a highly controversial issue) and slowly re-focus negotiating efforts on topics such as climate finance, technology transfer and technical assistance. ${ }^{41}$ On the other, the emergence at COP $19^{42}$ of a new bottom-up approach to climate change mitigation (embodied by the INDC/NDC process and ultimately enshrined in the Paris Agreement) has effectively concurred to reshape the entire discourse around response measures, not only extending the applicability of emissions reduction obligations to all Parties (including developing country Parties), but more importantly doing so in a way which reflects their common but differentiated responsibilities and respective capabilities, as well as the different national circumstances. ${ }^{43}$

\footnotetext{
${ }^{39}$ Keane (n 27) 4.

${ }^{40}$ UNFCCC (n 26) 22.

${ }^{41}$ Chris Wold, Don Gourlie and Amelia Schlusser, 'Climate Change, International Trade, and Response Measures: Options for Mitigating Climate Change Without Harming Developing Country Economies' (2014) 46 The George Washington International Law Review 531.

${ }^{42}$ UNFCCC, 'Report of the Conference of the Parties on its nineteenth session, held in Warsaw from 11 to 23 November 2013. Addendum. Part two: Action taken by the Conference of the Parties at its nineteenth session' (31 January 2014) UN Doc FCCC/CP/2013/10/Add.1.

${ }^{43}$ Paris Agreement, Art. 4.3.
} 
The main consequence of this evolution is two-fold. First, it is no longer possible to only look at the cross-border effects of response measures implemented in developed countries. Rather, an increasing role will be played by purely domestic considerations, as more developing countries start to adopt their own climate change mitigation policies and programmes. Secondly, it is important to realize that the new bottom-up architecture of climate governance emphasizes the opportunities that the implementation of response measures brings for diversifying the economies of developing countries. In other words, if each country has the opportunity (and obligation) of designing its own response measures, this creates a powerful incentive to do so through actions that are conducive to economic diversification, just transition of the work force, and job creation. In turn, however, the potentially competing nature of countries' interests and priorities creates the urgent need to strengthen international cooperation and promote synergies between response measures and international trade, so as to avoid unilateral resort to trade-restrictive measures that could substantially reduce market opportunities and hinder the diversification efforts of the most vulnerable economies. ${ }^{44}$

\subsection{Framing the mapping of response measures through the lenses of economic diversification}

As mentioned in the previous section, a necessary precondition for analysing the extent to which it is possible to build mutually supportive trade and climate regimes is represented by the need to understand how (and if) the response measures currently contained in the INDCs/NDCs can support (or hinder) economic diversification. Building on the mapping conducted in Chapter 2, the five categories of response measures identified thereby offer an opportunity to discuss the potential effects of such measures on economic diversification, at both the domestic and cross-border level. Although our grouping differs from the categorization of response measures proposed by the UNFCCC Secretariat in 2009 and based on discussions under the Ad Hoc Working Group on Further Commitments for Annex I Parties under the Kyoto Protocol (AWG-KP), ${ }^{45}$ our analysis of positive and negative impacts broadly mirrors the one conducted at the UNFCCC level, and will be described below. Examples will be taken primarily from the INDCs/NDCs of countries that could potentially be most affected by the implementation of response measures and, consequently, most interested in the interplay between these measures and economic diversification (see Section 3.2.1). From this perspective, it should also be emphasized that the pursuit of diversification through actions and plans that have mitigation co-benefits is explicitly mentioned in the INDCs of five Gulf Cooperation Council

\footnotetext{
44 Keane (n 27) 4; and Wold, Gourlie and Schlusser (n 37).

${ }^{45}$ UNFCCC (n 26).
} 
members (namely Bahrain, Kuwait, Saudi Arabia, Qatar and the United Arab Emirates). The specific reference is in line with the commitments announced in 2012 by Bahrain, Saudi Arabia, Qatar and the United Arab Emirates during COP18 (i.e. the so-called Economic Diversification Initiative). ${ }^{46}$

\subsubsection{Measures related to the energy sector}

As shown in Chapter 2, under this category we have mapped any measure relating to the energy sector with the exception of financial, market-based and direct trade measures (such as, inter alia, subsidies, domestic carbon taxes, and R\&D expenditures), all of which are listed under 'financial and direct trade measures'. To an extent, this represents a residual category, which essentially consists of green public investments and command and control measures such as energy policy reforms, regulatory standards and goods/technology mandates. Typical examples from this category that can be found in the INDCs/NDCs include commitments to increase the share of renewables within the domestic energy mix, construction of hydroelectric power plants, renewable energy mandates, improvements to energy grids, and so forth (Table 1):

Table 1: Examples of INDC/NDC response measures in the "Energy Sector" category.

\begin{tabular}{|l|l|}
\hline Country & Response measures \\
\hline Bahrain & $\begin{array}{l}\text { "Bahrain Petroleum Company (BAPCO) project consisting of the installation of } 21,000 \\
\text { smart solar panels to generate a substantial number of Kwhs of electricity annually. } \\
\text { The 5MW PV grid-connected plant aims at demonstrating PV solar technology under } \\
\text { local conditions to support up scaling of renewable energy." (p.3) }\end{array}$ \\
\hline China & $\begin{array}{l}\text { "Achievement of the installed capacity of wind power reaching } 200 \text { gigawatts, the } \\
\text { installed capacity of solar power reaching around } 100 \text { gigawatts and the utilization of } \\
\text { thermal energy reaching } 50 \text { million tons coal equivalent by 2020." (p.7) }\end{array}$ \\
\hline Saudi Arabia & $\begin{array}{l}\text { "Investment in and implementation of ambitious programs for renewable energy to } \\
\text { increase its contribution to the energy mix. The scope will include solar PV, solar } \\
\text { thermal, wind and geothermal energy and waste to energy systems." (p.3) }\end{array}$ \\
\hline
\end{tabular}

When implemented domestically in countries that experience a high degree of reliance on fossil fuel production and exports (such as GCC members), response measures in the energy sector are certainly positive for economic diversification, in that they facilitate the shift from vulnerable energy

46 UNFCCC Decision 24/CP.18, 'Economic Diversification Initiative' (8 December 2012) UN Doc FCCC/CP/2012/8/Add.3. 
sources to a diversified energy mix while supporting increased demand for high-skilled labour. ${ }^{47}$ At the same time, the impact of similar policies on other countries (especially developing countries) can be more uncertain. On the one hand, they might provide advantages for these countries' exporters and suppliers of environmentally sound technologies (when they exist, and provided that the measures themselves are not enacted in a discriminatory manner). On the other, they could instead block market access to foreign suppliers of substitutes for conventional goods and technologies (other fossil fuel producing countries, for example). ${ }^{48}$

Given the vague wording with which the measures grouped in this category are phrased in the INDCs/NDCs, there is limited scope for predicting what the specific outcomes could be in practice, as much will depend on how the related domestic policies will be drafted. In particular, whilst it is clear that sustaining long-term growth through a diversification of the energy mix already constitutes a priority for many fossil fuel exporting countries (as emphasized by the Economic Diversification Initiative referenced above), it also remains evident that a substantial contribution from oil exports revenues will continue to be necessary to fund this transition. ${ }^{49}$

\subsubsection{Green industrial policies}

The category of green industrial policies mainly concerns standards, labelling requirements and other command and control measures in the field of industrial production of goods, focusing either on the energy performance of the goods themselves or on PPMs. ${ }^{50}$ In some cases, these measures go beyond standard-setting to ban the use of certain goods altogether (e.g. Viet Nam's commitment to "remove obsolete and energy consuming technologies in energy production and consumption systems") or flat-out develop plans to boost the service sector as an alternative to carbon-intensive industrial development (e.g. Qatar's pledge to diversify its economy by promoting the sustainable tourism sector).

Despite being domestic in nature, standards and labelling requirements usually apply to imported goods as well, and as such might have both domestic implications and (un)intended cross-

\footnotetext{
${ }^{47}$ UNFCCC, 'Just Transition of the Workforce, and the Creation of Decent Work and Quality Jobs. Technical Paper by the Secretariat' (26 October 2016) UN Doc FCCC/TP/2016/7, 12.

${ }^{48}$ UNFCCC (n 26) 6.

${ }^{49}$ The Intended Nationally Determined Contribution of the Kingdom of Saudi Arabia under the UNFCCC (November 2015) <http://www4.unfccc.int/submissions/INDC/Published\%20Documents/Saudi\%20Arabia/1/KSAINDCs\%20English.pdf> accessed 24 November 2016.

${ }^{50}$ Like the commitments mapped in the 'energy sector' category, the measures listed here do not include financial direct and trade measures.
} 
border effects. At the domestic level, it has been argued that these schemes, when properly crafted, ${ }^{51}$ can promote innovation and thereby boost so-called traditional economic diversification (which entails moving up value chains within traditional economic sectors), ${ }^{52}$ provided that the country already owns a domestic industry in the regulated sector. By contrast, whilst they might also have positive impacts for other countries which already have environmentally sound technologies, depending on the specifications they contain, these measures are also bound to have adverse effects for countries exporting carbon-intensive goods, inducing a loss of market share for those exporters that do not have the capacity to comply with new regulations. In turn, this could bring about diminishing revenues from traditional sectors, causing less capital to be available for diversification investments.

Efficiency standards and eco-labelling requirements (targeting either goods themselves or PPMs) represent a consistent component of many INDCs/NDCs (see Table 2), and as such might have an important role to play in the fulfilment of the respective commitments under the Paris Agreement. As with the measures discussed above for the energy sector, domestic legislation will prove instrumental in determining the contribution of green industrial policies to diversification, but it can already be argued that the widespread adoption of standards which can be observed in the INDCs/NDCs is certainly promising. More specifically, by preventing the dumping of obsolete goods in countries with lower standards and levelling the playing field, a relatively uniform take-up of these measures might create incentives to innovation in many developing countries which have the potential to move up value chains, especially if coupled with a parallel boost to technology transfer and FDI. In addition, it could help small and medium enterprises (SMEs) in developing countries access international markets from which they were once excluded because of lack of compliance with existing standards.

Table 2: Examples of standards and labelling requirements included in INDCs/NDCs (including focus on both PPMs and energy performance of goods):

\begin{tabular}{|l|l|l|}
\hline Country & Industrial Sector & Response measure \\
\hline Colombia & Economy-wide & $\begin{array}{l}\text { "Sectorial Mitigation Action Plans (SMAPs) that aim to } \\
\text { maximize the carbon-efficiency of economic activities at the } \\
\text { national and sectorial levels." (p.8) }\end{array}$ \\
\hline
\end{tabular}

${ }^{51}$ See for example Charles Edquist and Jon Mikel Zabala-Iturriagagoitia, 'Public Procurement for Innovation as Mission-oriented Innovation Policy' (2012) 41 Research Policy 1757; and Herman R J Vollebergh and Edwin Van der Werf, 'The Role of Standards in Eco-Innovation: Lessons for Policymakers' (2014) 8(2) Review of Environmental Economics and Policy 230.

${ }^{52}$ UNFCCC (n 31) 4. 


\begin{tabular}{|l|l|l|}
\hline India & Home Appliances & $\begin{array}{l}\text { "Standards and Labeling Programme to provide consumers } \\
\text { with information about the energy consumption of an } \\
\text { appliance." (p.11) }\end{array}$ \\
\hline Saudi Arabia & Building/Transportation/Various & $\begin{array}{l}\text { "Introduction of efficiency standards in the building and } \\
\text { transportation sectors as well as the implementation of } \\
\text { energy efficiency measures, in various industrial } \\
\text { establishments." (p.3) }\end{array}$ \\
\hline $\begin{array}{l}\text { Uganda } \\
\text { Enited Arab }\end{array}$ & Transportation & $\begin{array}{l}\text { "Development and enforcement of building codes for energy } \\
\text { efficient construction renovation." (p.10) }\end{array}$ \\
\hline
\end{tabular}

\subsubsection{Green government procurement}

When discussing the category of green government procurement, we have stated that procurement practices, although not widely included in the INDCs/NDCs, are nonetheless considered to be important tools to support innovation and create demand for low-carbon goods and services. At the same time, however, we have emphasized that on the short term such measures can be tradesupportive (and thus promote technology transfer) or trade-restrictive (e.g. as a means of protecting infant domestic industries), depending on the way in which they are drafted. These connotations reverberate on the implications of green government procurement obligations for economic diversification, in the sense that such implications will be positive (both domestically and for other countries) whenever the obligations are drafted in a non-discriminatory way, so as to promote the transfer of low-carbon technologies, and negative whenever they are instead designed to protect inefficient domestic industries and thereby hinder innovation and beneficial competition. ${ }^{53}$

With respect to the commitments mapped in Chapter 2, it appears that response measures relating to green government procurement are extremely limited, and while some potential for traditional economic diversification can be seen in the fields of public transportation, public buildings and public lighting, further analysis will be needed to evaluate the possibility of domestic industries in many developing countries to effectively take part in the procurement process and move up value chains. Some examples are nonetheless provided in Table 3 below.

\footnotetext{
${ }^{53}$ On the other hand, however, it has also been argued that economic diversification in developing countries might benefit from a certain degree of protection of domestic firms through domestic content requirements in government procurement practices. See for example Michael Warner, Local Content in Procurement: Creating Local Jobs and Competitive Domestic Industries in Supply Chains (Greenleaf 2011) 23.
} 
Table 3: Examples of response measures in the green government procurement category.

\begin{tabular}{|l|l|l|}
\hline Country & Typology & Response measure \\
\hline Lesotho & Public Transportation & $\begin{array}{l}\text { "Investments in fuel-efficient vehicles for public transportation." } \\
\text { (page not numbered). }\end{array}$ \\
\hline Burkina Faso & Public Building & $\begin{array}{l}\text { "Promotion of architectural structures that use materials that are } \\
\text { local, renewable and insulating and have a low energy cost for all } \\
\text { public construction." (p.38) }\end{array}$ \\
\hline Senegal & Public Lighting & $\begin{array}{l}\text { "Energy efficiency in street lighting (replacing 75,000 } \\
\text { streetlights)." (p.9) }\end{array}$ \\
\hline
\end{tabular}

\subsubsection{Financial and direct trade measures}

Financial and direct trade measures comprise the most substantial category in our mapping study. This category encompasses two broad areas, namely: (i) purely domestic measures, such as domestic carbon taxes and levies, subsidies (or removal of subsidies), market mechanisms (e.g. FITs, RPS, and emissions trading schemes), and investments in R\&D; and (ii) trade-related measures, such as tariffs and import duties, border tax adjusments based on carbon content, and import bans. ${ }^{54}$ As evidenced in Section 2.3.3.1, purely domestic measures, and particularly taxes, subsidies and marketbased mechanisms, represent a major focus in countries' efforts to meet their obligations under the Paris Agreement, and from this perspective they also carry a lot of potential implications for economic diversification.

\subsubsection{Domestic measures}

The first sub-category consists of financial measures that are purely domestic in scope, such as taxes, subsidies to consumers of low-carbon goods, domestic market mechanisms and R\&D expenditures (Table 4).

\footnotetext{
${ }^{54}$ It should be noted that this distinction does not concern the effects of the measures, as subsidies or domestic carbon taxes, for example, can obviously also have impacts on competitiveness and trade flows. Rather, the distinction indicates the origin of the good or service targeted by a measure: domestic measures primarily target domestic products (with the exception of consumption subsidies, which do not discriminate between domestic and foreign producers), while trade-related measures are imposed on imported products.
} 
Table 4: Examples of domestic financial measures (mapped as part of the 'Financial and direct trade measures' category).

\begin{tabular}{|c|c|c|}
\hline Country & Typology & Response measure \\
\hline China & $\begin{array}{l}\text { Taxes } \\
\text { (preferential } \\
\text { taxation) }\end{array}$ & $\begin{array}{l}\text { "Implementation of preferential taxation policies for promoting the } \\
\text { development of new energy and to improve mechanisms of pricing, } \\
\text { grid access and procurement mechanisms for solar, wind and hydro } \\
\text { power." }\end{array}$ \\
\hline Chile & Carbon tax & $\begin{array}{l}\text { "CO2 emission tax. Annual tax benefit lien on carbon dioxide, among } \\
\text { other gases, produced by facilities whose stationary sources, made up } \\
\text { of boilers or turbines, have an aggregate thermal power equal or } \\
\text { higher than } 50 \mathrm{MWt.}\end{array}$ \\
\hline Guatemala & Subsidies & $\begin{array}{l}\text { "Establishment of a program of tax incentives and subsidies focused } \\
\text { on the use of clean energy for public and private transport, including } \\
\text { legislation to regulate GHG emissions in the collective and individual } \\
\text { public transport." }\end{array}$ \\
\hline Ethiopia & $\begin{array}{l}\text { Removal of } \\
\text { subsidies }\end{array}$ & "Removal of fossil fuel subsidies." (already implemented) \\
\hline Egypt & $\begin{array}{l}\text { Emissions } \\
\text { trading schemes }\end{array}$ & $\begin{array}{l}\text { "A national market for carbon trading may be established. This } \\
\text { national market may further be developed into a regional market." }\end{array}$ \\
\hline Ghana & Feed-in Tariffs & "Set up feed-in-tariff for renewable energy technologies." \\
\hline
\end{tabular}

Domestic measures might not only provide more opportunities for national firms, but also expand the market share for green energy technology producers based in developing countries. At the same time, subsidies to domestic producers of environmentally sound technologies might be negative for foreign competitors, and domestic content requirements in FITs and RPS could also work as protectionist measures temporarily shielding national firms from the competition of economies in transition. In addition, the use of emissions trading schemes of carbon taxes might merely promote the relocation of carbon-intensive industries in developing countries (even though the point is controversial, in line with the long-standing pollution haven hypothesis) ${ }^{55}$ thereby blocking innovation and economic diversification in the latter. Finally, removing subsidies to fossil fuel consumption and production might be conducive to diversification domestically, but in the case of production, subsidies

${ }^{55}$ See for example Eric Neumayer, 'Pollution Havens: Do Developing Countries Set Inefficient Environmental Standards to Attract Foreign Investment?' in Eric Neumayer, Greening Trade and Investment: Environmental Protection Without Protectionism (Earthscan 2001); Eric Neumayer, 'Pollution Havens: An Analysis of Policy Options for Dealing with an Elusive Phenomenon' (2001) 10(2) Journal of Environment and Development 147; Jennifer Clapp, 'What the Pollution Havens Debate Overlooks' (2002) 2(2) Global Environmental Politics 11; and Aaron Cosbey and Richard Tarasofsky, Climate Change, Competitiveness and Trade. A Chatham House Report (Chatham House 2007). 
could in turn increase the market share of other fossil fuel exporting countries, according to some estimates. $^{56}$

Within domestic measures, expenditures in R\&D require a separate consideration. The importance of such public investments in promoting economic diversification, in fact, will primarily be determined by how R\&D results are used to stimulate innovation and leverage the opportunity of a country to participate in global value chains, ${ }^{57}$ because their free availability (or avability on commercial terms) might facilitate technology transfer to developing countries, whilst licensing could by contrast allow the innovating country "to use the new technology to gain a competitive advantage". ${ }^{58}$

\subsubsection{Trade-related measures}

Trade-related measures, including tariffs and import duties and import bans, ${ }^{59}$ are predominantly mentioned in the INDCs/NDCs of developing countries, and as such can grant domestic producers of environmentally sound technologies with a form of protection of infant industries and a simultaneous loss of market share for competitors from developing countries. Some examples are provided in Table 5.

Table 5: Examples of trade-related response measures (mapped as part of the 'Financial and direct trade measures' category).

\begin{tabular}{|l|l|l|}
\hline Country & Typology & Response measure \\
\hline Cook Islands & Tariffs & $\begin{array}{l}\text { "Customs Tariff Act } 2012 \text { established noteworthy duty rates on the } \\
\text { importation of motor vehicles." }\end{array}$ \\
\hline Guyana & $\begin{array}{l}\text { Removal of } \\
\text { tariffs }\end{array}$ & $\begin{array}{l}\text { "Legislation has been enacted to remove import duty and tax barriers for } \\
\text { the importation of renewable energy equipment, compact fluorescent lamps } \\
\text { and LED lamps to incentivize and motivate energy efficient behavior." }\end{array}$ \\
\hline Kuwait & Import ban & $\begin{array}{l}\text { "Environmental Protection law prevents importing any hardware or } \\
\text { equipment that does not match the specifications of energy conservation." }\end{array}$ \\
\hline
\end{tabular}

${ }^{56}$ UNFCCC (n 26) 7.

57 Daria Taglioni and Deborah Winkler, Making Global Value Chains Work for Development (Trade and Development Series, World Bank Group 2016) 185.

${ }_{58}$ UNFCCC (n 26) 8.

59 In practice, border tax adjustments could be considered akin to tariffs, because their impact would be equivalent to that of an increased tariff, reducing market share for foreign producers. 
Trade-related measures can provide preferential treatment for low-carbon goods and technologies, positively impacting the exports of other countries that are also producing them. It should be noted that trade liberalization for low-carbon goods could also make it more difficult for developing countries to protect infant industries in the affected sectors. In turn, however, the technology spillovers and direct transfer of technologies would also drive diversification, and in some cases, give rise to 'technological leapfrogging' as developing countries "bypass intermediate technologies". ${ }^{60}$

\subsubsection{International cooperation}

As discussed in Chapter 2, commitments to international and regional cooperation on climate change mitigation represent an important component of several INDCs/NDCs. This reflects the centrality attributed to the themes of market-based mitigation, climate finance and technology transfer under the Paris Agreement, as well as the more general attention paid to the implementation of response measures in developing countries. By their very nature, the proposed actions mapped in this category would have to be agreed and coordinated internationally, which implies that there is ample scope for ensuring that their impacts on diversification are positive at both the domestic and crossborder level. At the same time, many of the contributions (or requests of contributions) contained in the INDCs/NDCs limit themselves to quantifying the estimated costs of the implementation of certain mitigation activities, thereby making it hard to evaluate such impacts in the absence of real financial flows and specific mechanisms for the disbursement of funds. As a consequence, the main measures for which it is possible to discuss the implications for economic diversification under this category are essentially two, and namely: (i) commitments to facilitate FDI and technology transfer (including through South-South cooperation); and (ii) statements of support for the establishment of international market-based mechanisms ot the use of existing ones (e.g. emissions trading schemes, international offsets) (Table 6).

Table 6: Examples of INDC/NDC response measures to be implemented through international commitments.

\begin{tabular}{|l|l|l|}
\hline Country & Typology & Commitment/Statement \\
\hline Burundi & $\begin{array}{l}\text { Technology } \\
\text { transfer }\end{array}$ & $\begin{array}{l}\text { "Promotion of technology transfer to support research and development, } \\
\text { adopt new technologies, and harness them for the national context." }\end{array}$ \\
\hline
\end{tabular}

\footnotetext{
${ }^{60}$ UNFCCC (n 26) 13.
} 


\begin{tabular}{|l|l|l|}
\hline China & (p.11) \\
\hline $\begin{array}{l}\text { Technology } \\
\text { transfer / Climate } \\
\text { finance }\end{array}$ & $\begin{array}{l}\text { "Establishment of the Fund for South-South Cooperation on Climate } \\
\text { Change, providing assistance and support, within its means, to other } \\
\text { developing countries including the small island developing countries, } \\
\text { the least developed countries and African countries to address climate } \\
\text { change." (p.16) }\end{array}$ \\
\hline Morocco & $\begin{array}{l}\text { International } \\
\text { market-based } \\
\text { mechanisms }\end{array}$ & $\begin{array}{l}\text { "Morocco considers the establishment of international market-based } \\
\text { mechanisms of primary importance, in order to promote cooperation } \\
\text { between parties with respect to their mitigation contributions, as per } \\
\text { Article 6 of the Paris Agreement." (page not numbered) }\end{array}$ \\
\hline Pao Tome and & $\begin{array}{l}\text { International } \\
\text { market-based } \\
\text { mechanisms }\end{array}$ & $\begin{array}{l}\text { "Sao Tome and Principe supports the use of market mechanisms } \\
\text { including the results of mitigation pre-2020, such as the use of Emission } \\
\text { Reduction Certificates (ERCs) generated by CDM projects and } \\
\text { programs." (page not numbered) }\end{array}$ \\
\hline
\end{tabular}

Even before the adoption of the Paris Agreement, policies in the fields of technology transfer and technology cooperation had been identified by the IPCC as measures that could "conceivably play a significant role in an international climate regime". ${ }^{61}$ In addition to their potential to lower the relative cost of environmentally sound technologies, increase the efficiency of international R\&D activities, and facilitate investment of foreign capital into non-traditional sectors, these measures might also generate positive technological spillovers for countries that do not participate in a specific bilateral or plurilateral agreement, and as such trigger a domino effect towards diversification.

By contrast, the consequences of the establishment (or use) of international market-based mechanisms have been described as uncertain, even though a distinction should be made between emissions trading schemes and offset mechanisms. ${ }^{62}$ With respect to the former, it has been argued that if regional or international trading schemes are stringent enough, they might induce relocation of carbon-intensive industries or redirection of investment, locking host countries into polluting traditional sectors (but evidence on the topic is mixed). ${ }^{63}$ As for offset mechanisms, it is certainly possible that increased investment and employment in host countries promote economic diversification, but it is also evident that their success will in practice hinge on the effectiveness of MRV systems in ensuring the transparency and accountability of the entire framework.

\footnotetext{
${ }^{61}$ Robert N Stavins and others (n 5) 1035.

62 UNFCCC (n 26) 8-10.

${ }^{63}$ For information on the EU Emissions Trading Scheme, see for example IEA, Issues behind Competitiveness and Carbon Leakage: Focus on Heavy Industry (IEA information paper, IEA 2008).
} 


\subsection{Trade rules as a precondition for promoting economic diversification through response measures}

The main argument of this Chapter is that the universal, bottom-up nature of the INDCs/NDCs reshapes the relationship between economic diversification and response measures. In other words, the possibility for developing countries to design their nationally determined contributions in the light of respective national capabilities provides them with an opportunity to consider response measures as drivers of their own economic diversification and development, rather than as policies designed by others (i.e. developed countries) and characterized by a range of (mostly) negative effects that shall be minimized. Our analysis suggests that there is certainly scope for the current INDCs/NDCs to promote diversification, particularly in the countries where the measures are implemented. At the same time, the evidence for cross-border effects is more mixed, as the nature and magnitude of their impacts will largely hinge upon the design of domestic policies which are not necessarily reflected in the INDCs/NDCs. In addition, the way in which national implementation is carried out will also likely involve trade-offs. For example, domestic content requirements included in green government procurement practices or FIT schemes might protect infant industries and thus promote diversification, but they could also hinder innovation and technology transfer.

Taken together, these considerations concur to explain why the multilateral regulation of international trade should play a major role in the debate around economic diversification and response measures, while also suggesting what this role could be in practice. There are at least two reasons for considering trade rules as necessary components of the equation. First, most of the adverse impacts outlined in Section 3.3. "are (or will be) felt through the mechanisms of trade", ${ }^{64}$ as specified in Section 3.4. Second, trade liberalization is widely considered as one of the main drivers of both import and export diversification, an argument that is confirmed by our analysis of the response measures contained in the INDCs/NDCs. ${ }^{65}$

From a legal perspective, a precondition for response measures to be able to promote diversification is therefore represented by the need to take the international trade regime into account when implementing the INDCs/NDCs. On the one hand, domestic mitigation policies that are bound

\footnotetext{
${ }^{64}$ ibid 8. More specifically, the effects of response measures are felt through the mechanisms of trade in two ways. First, the change in the demand for a certain good or service in the country which implements a response measure is going to impact foreign exporters of that good or service. Secondly, the measure itself can influence trade flows, to the extent that it explicitly lifts barriers (or applies restrictions) to certain imports or otherwise de facto affects them.

${ }^{65}$ See Pushan Dutt, Ilian Mihov and Timothy Van Zandt, 'Trade Diversification and Economic Development' (28 October 2008) mimeo, INSEAD; and OECD, 'The Impact of Trade Liberalisation on Jobs and Growth' (2011) OECD Trade Policy Paper No. 107 <http://www.oecd-ilibrary.org/trade/the-impact-of-trade-liberalisation-on-jobsand-growth 5kgj4jfi1nq2-e> accessed 24 November 2016.
} 
have trade-restrictive effects (e.g. a carbon tax on carbon-intensive goods) need to carefully consider design options that are consistent within the framework provided by the WTO and the relevant FTAs. On the other, trade rules should in turn be made more supportive of diversification, for example by recognizing a fair policy space for developing countries to subsidy a shift in their economic structure, preventing protectionist policies by developed countries in the environmental goods and services sector, and facilitating technology transfer and adoption of low-carbon technologies. Accordingly, Chapter 4 will conduct an analysis of the complex interlinkages that exist between the trade and climate regimes, with a particular emphasis on the possibility for FTAs to serve as positives driver for the implementation of the INDCs/NDCs at the national and regional level. ${ }^{66}$

\footnotetext{
${ }^{66}$ With respect to the larger debate on the mutual supportiveness of UNFCCC and WTO rules, see for example James Bacchus, Global Rules for Mutually Supportive and Reinforcing Trade and Climate Regimes (E15 Expert Group on Measures to Address Climate Change and the Trade System - Policy Options Paper, E15Initiative, International Centre for Trade and Sustainable Development and World Economic Forum 2016).
} 


\section{The incorporation of climate-related measures into Free Trade Agreements}

\subsection{Introduction and methodology}

Notewithstanding their different goals, trade and climate change are inescapably interlinked. As explained in Chapter 2 and 3, climate policies will manifestly affect trade rules, whether postitively or negatively. In addition, Free Trade Agreements (FTAs) provide many opportunities to mitigate climate change. First, economic growth that result from the liberalization of trade in goods and services generates useful economic resources to allow the transition from carbon-intensive industries into cleaner and less polluting industries. ${ }^{67}$ Second, FTAs provide a suitable framework to reduce/eliminate barriers on environmental goods and services, which leads to lowering the cost of green energy technologies. ${ }^{68}$ Finally, many FTAs incorporate countries' response measures submitted in their INDCs/NDCs as a way to strengthen the capacity of states to fulfill their climate change commitments.

When implementing these instruments, states are shifting the market space from carbonintensive industries to green industries and hence promoting economic diversification. Therefore, the most pressing challenge when designing FTAs is to find a balance between promoting trade liberalization on the one hand and allowing a policy space for countries to implement their obligations under the UNFCCC on the other hand, in order to ensure that trade and climate policies are mutually supportive. Examples of FTAs explicitly recognizing the relationship between trade and environmental protection include, inter alia:

\begin{tabular}{|l|l|}
\hline Agreement & Relevant Provision \\
\hline Canada-Peru & $\begin{array}{l}\text { "The Parties recognize the mutual supportiveness between trade and environment } \\
\text { policies." Art. } 1701(2)^{69}\end{array}$ \\
\hline EU-Korea & $\begin{array}{l}\text { "The Parties recognize that economic development, social development and } \\
\text { environmental protection are interedepent and mutually reinforcing components of }\end{array}$ \\
\hline
\end{tabular}

${ }^{67}$ Joshua Meltzer, 'The Trans-Pacific Partnership Agreement, the environment and climate change' in Tania Voon (ed) Trade and Liberalization and International Co-operation: A legal Analysis of the Trans-Pacific Partnership Agreement (Edward Elgar 2014) <http://www.brookings.edu/wp-content/uploads/2016/06/MeltzerTPP-Environment-Chapter version-2.pdf> accessed 15 December 2016, 1.

${ }^{68}$ ibid, 20. Reducing tariffs on all goods and services to zero in FTAs would overcome the need to specifically target environmental goods and services. Even if it is not explicitly mentioned in the FTAs, trade liberalization covers all types of goods and services.

${ }^{69}$ Canada-Peru Free Trade Agreement (signed 29 May 2008, entered into force 1 August 2009) $<$ http://www.international.gc.ca/trade-agreements-accords-commerciaux/agr-acc/peru-perou/peru-toc-peroutdm.aspx?lang=eng $>$ accessed 12 December 2016, art. 1701(2). 
This Chapter analyzes the role of FTAs in addressing climate change challenges, with a particular emphasis on the possibility for these agreements to serve as positive drivers for the implementation of response measures at the national and regional level. ${ }^{71}$ In doing so, the Chapter emphasizes the need to 'provide a level playing field between clean and fossil energies' in order to achieve climate change mitigation obligations. ${ }^{72}$ States have realized that they need to use trade tools to undertake these obligations, as shown by the response measure adopted in the INDCs/NDCs mapped in Chapter 2. These measures could include taxes, FITs, subsidies to consumption of lowcarbon goods, market mechanisms, and other trade measures. To ensure their effective implementation, these response measures need to be in line with states' trade obligations under FTAs.

Section 4.2 identifies the general architecture of climate change provisions included in FTAs and the main issues that are covered. Section 4.3 deals specifically with different climate-related measures adopted by parties in their FTAs such as, policies promoting the production and trade in environmental goods and services, subsidy reform for green energy, standards, technical regulations and conformity assessment procedures, and international cooperation (the provision of financial support, technology transfer from developed countries to developing countries to implement their mitigation commitments). Section 4.3 identifies the exceptions adopted in FTAs related to the use of measures, including environmental measures, necessary to protect human, animal, or plant life or health. Such exceptions are specifically relevant for mitigation and financing measures to respond to climate change in developing countries.

With regard to methodology, this chapter relies on TREND Codebook (TRade and ENvironment Database), a project created by Professor Jean Frédéric Morin, aiming to identify more than 300 different types of environmental provisions in more than 660 trade agreements. ${ }^{73}$ In addition, this chapter also focuses on environmental chapters included in the most recent trade agreements,

\footnotetext{
${ }^{70}$ European Union-South Korea Free Trade Agreement (signed 23 May 2009, entered into force 11 July 2011) $<$ http://ec.europa.eu/trade/policy/countries-and-regions/countries/south-korea/> accessed 10 December 2016, art. 13.1(2)

${ }^{71}$ Climate change provisions include any provision addressing environmental protection even when the terms climate change are not included.

72 James Bacchus (n 66) 7.

73 Jean-Frédéric Morin, 'TREND TRade and ENvironment Database Codebook,' Canada Research Chair in International Political Economy, University of Laval (July 2016) <http://www.chaire-epi.ulaval.ca/trend > accessed 17 November 2016 [hereinafter Codebook].
} 
such as Comprehensive Economic and Trade Agreement ${ }^{74}$, Trans-Pacific Partnership ${ }^{75}$ and EUSingapore Free Trade Agreement. ${ }^{76}$ The aim is to identify overall trends of climate change related provisions in trade agreements that have effect on the response measures we identified in Chapter 2 , and specifically the ones that promote economic diversification. ${ }^{77}$

\subsection{The Architecture of climate change provisions in FTAs}

In order to achieve coherence between the climate and trade regimes, many FTAs include a separate chapter on environmental protection, which gives Parties a leeway to adopt trade measures that are specifically targeted to implement climate change obligations while leading to economic development and diversification. Whilst environmental protection provisions in trade agreements differ considerably, they usually cover six main areas that are directly relevant to climate change protection, namely:

- The right of the parties to regulate the level of environmental protection;

- The non-derogation commitment; ${ }^{78}$

- The commitment by the parties to adopt, maintain and implement laws and regulations to fulfill their environmental obligations;

- Means to encourage environmental protection including, the promotion of renewable and clean energy, establishment of international standards, subsidy reform to promote climate-friendly goods and services;

- Measures on international cooperation and technology transfer;

${ }^{74}$ EU-Canada Comprehensive Economic and Trade Agreement (signed on 30 October 2016, not yet in force) <http://ec.europa.eu/trade/policy/in-focus/ceta/ceta-chapter-by-chapter/> accessed 12 December 2016.

${ }^{75}$ In Honolulu, Hawaii, on 12 November 2011, the Leaders of the nine Trans-Pacific Partnership countries Australia, Brunei Darussalam, Chile, Malaysia, New Zealand, Peru, Singapore, Vietnam, and the United States announced the achievement of the broad outlines of an ambitious, 21st-century Trans-Pacific Partnership (TPP) agreement. See Trans-Pacific Partnership (signed 4 February 2016) <https://ustr.gov/trade-agreements/freetrade-agreements/trans-pacific-partnership/tpp-full-text> accessed 13 December 2016.

76 EU-Singapore Free Trade Agreement (signed 17 October 2016, did not enter into force yet) <http://trade.ec.europa.eu/doclib/docs/2013/september/tradoc 151766.pdf> accessed November 14, 2016.

${ }^{77}$ This chapter does not include domestic policies and legislations adopted by countries for the inclusion of environmental protection in trade agreements. For more detailed information on this subject, see Clive George, 'Environment and Regional Trade Agreements: Emerging Trends and Policy Drivers' (2013) OECD Trade and Environment Working Papers 2013/04 <http://www.oecdilibrary.org/docserver/download/5iz0v4q45g6h.pdf?expires=1479629689\&id=id\&accname=guest\&checksum=7B 40CA5DB225ECC41045E70E7033C180> accessed 20 November 2016.

${ }^{78}$ An example for the non-derogation commitment is, 'it is inappropriate to encourage trade or investment by weakening or reducing the protections afforded in its environmental laws' United States-Korea Free Trade Agreement (signed 30 June 2007, entered into force 15 March 2012) <https://ustr.gov/trade-agreements/freetrade-agreements/korus-fta> accessed 21 November 2016, art. 20.3.1(b) [hereinafter KORUS]. 
- Dispute settlement mechanisms.

These different provisions show the complementary role that FTAs can play to mitigate climate change impacts. As noted by Morin and others, FTAs offer another venue to strengthen climate commitments and sometimes to achieve more stringent and more precise obligations on states compared to the multilateral environmental agreements. This is mainly due to the limited number of Parties involved, the breadth of issues covered under FTAs and the resulting possibilities for bargaining and issue linkages. ${ }^{79}$ Additionally, some of the provisions adopted in the FTAs provide a policy space for the implementation of response measures included in the parties INDCs/NDCs in way that is consistent with trade rules. The analysis of climate provisions in trade agreements focus on those response measures, identified in Chapter 3, which have positive effects on economic diversification, at both the domestic and cross-border level.

Many FTAs recognize the use of trade measures to achieve environmental protection, including climate change mitigation commitments. For instance:

\begin{tabular}{|l|l|}
\hline Agreement & Relevant Provision \\
\hline Chile-US & $\begin{array}{l}\text { "The parties recognize the importance of multilateral environmental agreements, } \\
\text { including the appropriate use of trade measures in such agreements to achieve } \\
\text { specific environmental goals." (Art.19.9) }\end{array}$ \\
\hline EU-Colombia/Peru & $\begin{array}{l}\text { "The Parties agree to consider actions to contribute to achieving climate change } \\
\text { mitigation and adaptation objectives through their trade and investment policies."81 } \\
\text { (Art. 275.5) }\end{array}$ \\
\hline
\end{tabular}

\subsection{Climate-related measures included in FTAs}

FTAs recognize the right of states to regulate the protection of the environment in their own territory. This regulation takes numerous forms, such as the right to determine their own environmental policies and the right to enforce environmental measures. In the context of climate change, the INDCs/NDCs submitted by countries and analyzed in details in Chapter 2 are considered the core commitments established by parties to the Paris agreement to exercise their regulatory right. The next

79 Jean-Frédéric Morin, Nicholas Michaud and Corintin Bialais, 'Trade negotiations and Climate Governance, the $\mathrm{EU}$ as a frontrunner but not yet a leader' (September 2016) IDDRI Issue Brief $N^{\circ} 10 / 2016$ $<$ http://www.iddri.org/Publications/Les-negociations-commerciales-et-la-gouvernance-climatique-I-UE-commeprecurseur,mais-pas-(encore)-meneur> accessed 12 Dec 2016.

${ }^{80}$ United States-Chile Free Trade Agreement (signed 6 June 2003, entered into force 1 January 2004) $<$ https://ustr.gov/trade-agreements/free-trade-agreements/chile-fta> accessed 10 December 2016, art. 19.9. Chile's INDC reveals its commitment to use trade measures to promote environmental goods, by imposing a tax on initial sale of lightweight vehicles, and charging a tax inversely proportional to vehicle performance. This climate change commitment is in line with Chile's obligations under the Chile-US FTA.

${ }_{81}$ Trade Agreement between the European Union and its member states, of the one part, and Colombia and Peru, of the other part (signed 26 June 2012 , entered into force $1^{\text {st }}$ June 2013 ) art.275.5 
sub-sections identify different climate-related measures adopted in FTAs relating to climate change mitigation:

- Policies promoting the production and trade/investment in environmental goods and services;

- Subsidy Reform for green energy and development;

- Standards, Technical Regulations and Conformity Assessment;

- International Cooperation.

\begin{tabular}{|c|c|c|}
\hline Climate-related measure & Agreement & Relevant Provision \\
\hline $\begin{array}{l}\text { Policies promoting the } \\
\text { production of } \\
\text { environmental goods and } \\
\text { services }\end{array}$ & EU-CARIFORUM & $\begin{array}{l}\text { "The Parties agree to cooperate, including by facilitating } \\
\text { support in the following areas: (e) assistance to producers } \\
\text { to develop and/or improve production of goods and } \\
\text { services, which the Parties consider to be beneficial to } \\
\text { the environment." } \\
\text { (art.191.2.e) }\end{array}$ \\
\hline $\begin{array}{l}\text { Policies promoting the } \\
\text { trade and investment in } \\
\text { environmental goods and } \\
\text { services }\end{array}$ & $\begin{array}{l}\text { Comprehensive } \\
\text { Economic and Trade } \\
\text { Agreement } \\
\text { (CETA) }\end{array}$ & $\begin{array}{l}\text { "The Parties shall ... pay special attention to facilitating } \\
\text { the removal of obstacles to trade or investment in goods } \\
\text { and services of particular relevance for climate } \\
\text { change mitigation and in particular trade or investment in } \\
\text { renewable energy goods and related services" }\end{array}$ \\
\hline $\begin{array}{l}\text { Subsidy Reform for green } \\
\text { energy }\end{array}$ & EU-Singapore & $\begin{array}{l}\text { "The Parties share the goal of progressively reducing } \\
\text { subsidies for fossil fuels" } \\
\text { (art. 13.11.3) }\end{array}$ \\
\hline $\begin{array}{l}\text { Standards, Technical } \\
\text { Regulation, Conformity } \\
\text { Assessment }\end{array}$ & EU-Singapore & $\begin{array}{l}\text { "The Parties shall specify technical regulations based on } \\
\text { product requirements in terms of performance, including } \\
\text { environmental performance..." }\end{array}$ \\
\hline International Cooperation & $\begin{array}{c}\text { Trans-Pacific } \\
\text { Partnership } \\
\text { (TPP) }\end{array}$ & $\begin{array}{l}\text { "The Parties recognize the importance of cooperation } \\
\text { as a mechanism to implement this Chapter, to enhance } \\
\text { its benefits and to strengthen the Parties' joint and } \\
\text { individual capacities to protect the environment and to } \\
\text { promote sustainable development as they strengthen their } \\
\text { trade and investment relations." } \\
\text { (art. 20.12.1) }\end{array}$ \\
\hline
\end{tabular}




\subsubsection{Policies promoting the production and trade in environmental goods and services}

Reducing tariffs on environmental goods and services is one of the trade measures that directly promote both climate change mitigation efforts and economic diversification. As explained by Meltzer, "providing a tariff cut for such goods would create the strongest incentive for industry to use less carbon-intensive production processes and thereby contribute the most to reducing GHG emissions. ${ }^{" 22}$ In addition, investment in the production and trade in these goods will have a major potential for creating new markets and trade opportunities. ${ }^{83}$ From July 2014, the EU and 16 other members of the WTO have been negotiating an Environmental Goods Agreement (EGA) to remove barriers to trade in environmental or "green" goods that are crucial for environmental protection and climate change mitigation. ${ }^{84}$ The first stage of the negotiations focus on removing tariffs on a broad list of environmental goods, the negotiators build on a list of 54 products on which the member countries of Asia-Pacific Economic Cooperation (APEC) have agreed to reduce import tariffs to $5 \%$ or less. EGA is proposed to be a living agreement, which would allow for addition of new products in the future. ${ }^{85}$ All these efforts aim to create "win win win" situations for trade, environment and development by establishing new markets for climate-friendly goods and services and thereby promoting economic diversification. ${ }^{86}$ Trade agreements include various types of norms encouraging the production of and trade or investment in environmental goods and services. Examples of FTAs promoting the production of environmental goods and services include:

${ }^{82}$ Meltzer (n 67) 21; see also Edvokia Moise and Ronald Steenblik, 'Trade-Related Measures Based on Processes and Production Methods in the Context of Climate-Change Mitigation' (3 August 2011) OECD Trade and Environment Working Paper 2011/04.

${ }^{83}$ Veena Jha, 'Trade Flows, Barriers and Market Drivers in Renewable Energy Supply Goods' (December 2009) Issue Paper No 10, International Centre for Trade and Sustainable Development $<$ http://www.ictsd.org/downloads/2011/12/trade-flows-barriers-and-market-drivers-in-renewable-energy-supplygoods.pdf> accessed 15 December 2016, 3.

${ }^{84}$ See generally Ronald Steenblik, 'Environmental Goods: A Comparison of the APEC and OECD Lists' (29 November 2005) OECD Trade and Environment Working Paper No 2005-04; and Robert Howse and Petrus van Bork, 'Options for Liberalising Trade in Environmental Goods in the Doha Round' (July 2016) Issue Paper No 2, International Centre for Trade and Sustainable Development.

${ }^{85}$ The Environmental Goods Agreement is being negotiated among Australia, Canada, China, Costa Rica, Chinese Taipei, the EU, Hong Kong (China), Japan, Korea, New Zealand, Norway, Switzerland, Singapore, US, Israel, Turkey and Iceland. Together these countries account for the majority of the world trade in environemntal goods. See International Trade Department of the European Union, 'The Environmental Goods Agreement (EGA): Liberalising trade in environmental goods and services' (updated July 2016) <http://trade.ec.europa.eu/doclib/press/index.cfm?id=1116> accessed 13 December 2016

86 World Trade Organization, 'Eliminating Trade Barriers on Environmental Goods and Services' $<$ https://www.wto.org/english/tratop e/envir e/envir neg serv e.htm>. For more information, see Mark Wu, 'Why Developing Countries Won't Negotiate: The Case of the WTO Environmental Goods Agreement (2014) 6(1) Trade Law \& Development 93. 


\begin{tabular}{|l|l|}
\hline Agreement & Relevant Provision \\
\hline $\begin{array}{l}\text { Canada-Colombia } \\
\text { (Annex I) }\end{array}$ & $\begin{array}{l}\text { "The priority areas identified by the Republic of Colombia for consideration in the initial } \\
\text { Work Program include, inter alia: (f) promotion of the production of environmental- } \\
\text { friendly goods and services." }\end{array}$ \\
\hline EU-CARIFORUM & $\begin{array}{l}\text { "2. Subject to the provisions of Article 7, the Parties agree to cooperate, including by } \\
\text { facilitating support in the following areas: (e) assistance to producers to develop and/or } \\
\text { improve production of goods and services, which the Parties consider to be beneficial } \\
\text { to the environment."88 Art. 191(2)(e) }\end{array}$ \\
\hline
\end{tabular}

Some FTAs aim at encouraging trade and investment in environmental goods, whether by promoting wide-ranging categories of goods and services or by identifying specific goods and services such as, solar panels, LED light bulbs, green vehicles etc. Examples of FTAs promoting trade and investment in environmental goods and srvices include:

\begin{tabular}{|l|l|}
\hline Agreement & Relevant Provision \\
\hline $\begin{array}{l}\text { Canada-Colombia } \\
\text { (Annex I) }\end{array}$ & $\begin{array}{l}\text { "The Parties shall encourage the promotion of the trade and investment of } \\
\text { environmental goods and services." (Art. 2.6) }\end{array}$ \\
\hline EU-Georgia & $\begin{array}{l}\text { "The Parties shall strive to facilitate the removal of obstacles to trade or investment } \\
\text { concerning goods and services of particular relevance to climate change mitigation, } \\
\text { such as sustainable renewable energy and energy efficient products and services." } \\
\text { (Art. 231) }\end{array}$ \\
\hline $\begin{array}{l}\text { New Zealand- } \\
\text { Taiwan }\end{array}$ & $\begin{array}{l}\text { "The Parties shall eliminate all tariffs on environmental goods upon entry into force of } \\
\text { this Agreement [...]. A list of environmental goods is attached as Annex 7. Annex 7: } \\
8712.00-\text { Bicycles and other cycles (including delivery tricycles), not motorized - }\end{array}$ \\
\hline
\end{tabular}

${ }^{87}$ Canada-Colombia agreement on the environment (signed 21 November 2008, entered into force 15 August 2011) <https://www.ec.gc.ca/caraib-carib/default.asp?lang=En\&n=FFEF249E-1> accessed 19 November 2016, Annex 1.

${ }^{88}$ Economic Partnership Agreement between the CARIFORUM States and the European Community and its Member States (signed 15 October 2008, provisional application began 29 December 2008) <http://eurlex.europa.eu/LexUriServ/LexUriServ.do?uri=OJ:L:2008:289:0003:1955:en:PDF> accessed 18 November 2016, Art. 191(2)(e) [hereinafter CARIFORUM].

${ }^{89}$ Canada-Colombia ( $n$ 86) Art.2.6. When examining Canada's response measures as identified in the country summary, investment in the development of clean technology products such as electric vehicle charging stations and wind hybrid power plants is included. This shows the consistency between response measures adopted by Canada and its trade obligations included in this trade agreement.

90 EU-Georgia Association Agreement (signed 27 June 2014, entered into force 1 July 2016) <http://eurlex.europa.eu/legal-content/EN/TXT/PDF/?uri=CELEX:22014A0830(02)\&from=EN> accessed 14 December 2016. 


\begin{tabular}{|l|l|}
\hline & $\begin{array}{l}\text { Bicycles and their spare parts exert positive effect on reducing exhaust emissions from } \\
\text { automobiles, air pollution and greenhouse effect." (Art. 3.2.a) }\end{array}$ \\
\hline CETA & $\begin{array}{l}\text { "1. The Parties are resolved to make efforts to facilitate and promote trade and } \\
\text { investment in environmental goods and services, including through addressing the } \\
\text { reduction of non-tariff barriers related to these goods and services. 2. The Parties } \\
\text { shall, consistent with their international obligations, pay special attention to facilitating } \\
\text { the removal of obstacles to trade or investment in goods and services of particular } \\
\text { relevance for climate change mitigation and in particular trade or investment in } \\
\text { renewable energy goods and related services." (Art. 24.9) }\end{array}$ \\
\hline EU-Colombia/Peru & $\begin{array}{l}\text { "Facilitating the removal of trade and investment barriers to access to, innovation, } \\
\text { development, and deployment of goods, services and technologies that can contribute } \\
\text { to mitigation or adaptation, taking into account the circumstances of developing } \\
\text { countries." }\end{array}$ \\
\hline
\end{tabular}

\subsubsection{Subsidy Reform for green energy}

Subsidy reform is one of the main tools used by governments to promote green energy. Free trade agreements include two types of norms addressing this issue:

- First type: subsidies granted for environmental purposes, such as green subsidies, subsidies necessary to adapt existing facilities to new environmental requirements, and subsidies granted for research in connection with environmental issues or programs.

- Second type: the elimination of subsidies harmful to the environment such as fossil fuel subsidies, ${ }^{94}$ which are considered the largest category of energy subsidies. ${ }^{95}$

${ }^{91}$ Agreement between New Zealand and the Separate Customs Territory of Taiwan, Penghu, Kinmen, and Matsu on Economic Cooperation (signed on 10 July 2013, entered into force on 1 December 2013) <http://www.nzcio.com/webfm send/59> accessed 30 November 2016, Chapter 17, Art.3 (2)(a), 10 July 201. [hereinafter ANZTEC].

92 EU-Canada ( $\mathrm{n} 74)$ art 24.9.

${ }^{93}$ Trade Agreement between the European Union and its member states, of the one part, and Colombia and Peru, of the other part (signed 26 June 2012 , entered into force $1^{\text {st }}$ June 2013) art.275.5.

${ }^{94}$ For more information on elimination of fossil fuel subsidies, see Laura Merrill, Andrea M Bassi, Richard Bridle and Lasse T Christensen, Tackling Fossil Fuel Subsidies and Climate Change: Leveling the Energy Playing Field (Nordic Council of $\quad$ Ministers 2015$)$ $<$ http://www.greengrowthknowledge.org/sites/default/files/downloads/resource/Tackling Fossil Fuel Subsidies and Climate Change Levelling the Energy Playing Field Nordic Concil of Ministers.pdf> accessed 16 November 2016.

${ }^{95}$ According to the International Energy Agency, fossil fuel subsidies amounted to $\$ 550$ billion in 2013 , whereas renewable energy subsidies amounted to $\$ 120$ billion. See Kasturi Das and Kaushik Ranjan Bandyopadhyay, Climate Change and Clean Energy in the 2030 Agenda: What Role for the Trade System? (ICTSD 2016) 4. 
As demonstrated in Chapter 2, when submitting their response measures, states have largely used subsidy reform to achieve their mitigation commitments, such as, the provision of subsidies for renewable energy (Afghanistan, Burkina Faso, Guatemala), or the removal of subsidies on fossil fuel (Ethiopia, Ghana, India, Nigeria, Sierra Leone), or the gradual reduction of subsidies on electricity (Kuwait, Morocco). ${ }^{96}$

To provide coherence between response measures and trade agreements obligations and to provide a complementary role to the fight against climate change, some FTAs include explicit reference to the permissibility of providing or eliminating subsidies to achieve environmental protection purposes. For example:

\begin{tabular}{|l|l|}
\hline Agreement & Relevant Provision \\
\hline EU-Singapore & $\begin{array}{l}\text { "The parties recognize the need to ensure that, when developing public support } \\
\text { systems for fossils fuels, proper account is taken of the need to reduce GHG emissions } \\
\text { and to limit distortions of trade as much as possible ... the Parties share the goal of } \\
\text { progressively reducing subsidies for fossil fuels. Such a reduction may be } \\
\text { accompanied by measures to alleviate the social consequences associated with the } \\
\text { transition to low carbon fuels. In addition, both Parties will actively promote the } \\
\text { development of a sustainable and safe low-carbon economy, such as investment in } \\
\text { renewable energies and energy efficient solutions."97 (Art.13.11.3) }\end{array}$ \\
\hline
\end{tabular}

\subsubsection{Standards, Technical Regulation and Conformity Assessment}

In addition to the financial and economic measures adopted by states in their INDCs/NDCs and their FTAs, states also rely on a set of non-tariff barriers to reduce costs and mitigate climate change challenges. These measures include, labeling, setting standards, and conformity assessment.

\begin{tabular}{|l|l|}
\hline Agreement & Relevant Provision \\
\hline EU-Singapore & $\begin{array}{l}\text { (1) Where international or regional standards exist with respect to products for the } \\
\text { generation of energy from renewable and sustainable non-fossil sources, the Parties } \\
\text { shall use these standards, or their relevant parts, as a basis for their technical } \\
\text { regulations [...] } \\
\text { (2) Where appropriate, the Parties shall specify technical regulations based on product } \\
\text { requirements in terms of performance, including environmental performance, rather } \\
\text { than design or descriptive characteristics."98 (Art. 7.5) }\end{array}$ \\
\hline
\end{tabular}

Energy-efficiency labelling requirements have been used widely to inform consumer on the energy efficiency of certain products, such as washing machines, cars or other devices. This labeling

\footnotetext{
${ }^{96}$ See Chapter 2.3.3.1, 12.

${ }^{97}$ EU-Singapore Free Trade Agreement (n 76) Art.13.11.3.

98 ibid, art. 7.5.
} 
technique encourages producers to invest in more energy-efficient products. ${ }^{99}$ FTAs also provide a way for governments to harmonize their technical standards and labelling schemes to promote transparency and incentivize industries to develop green technologies.

\subsubsection{International Cooperation and Climate finance}

In order to implement their climate related measures, developing countries need international assistance in the form of climate finance ${ }^{100}$, technology transfer to access environmental sound technologies, ${ }^{101}$ and capacity building support to integrate best practices in various sectors for climate change action. ${ }^{102}$

\begin{tabular}{|l|l|}
\hline Agreement & Relevant Provision \\
\hline EU-Central America & $\begin{array}{l}\text { "The Parties agree to cooperate, including by supporting technical assistance, training } \\
\text { and capacity building actions in, inter alia, the following areas: (b) promoting trade } \\
\text { related cooperation mechanisms as agreed by the Parties to help implement the } \\
\text { current and future international climate change regime." }\end{array}$ \\
\hline
\end{tabular}

In many FTAs, states have included capacity building and technical assistance commitments to implement specific programs, such as the Clean Development Mechanism of the Kyoto Protocol, or to assist developing countries in domestic carbon markets and in the trade and dissemination of environmentally sound goods and services. ${ }^{104}$ Examples include:

\begin{tabular}{|l|l|}
\hline Agreement & Relevant Provision \\
\hline Mexico-Japan & $\begin{array}{l}\text { "1. The Parties, recognizing the need for environmental preservation and improvement } \\
\text { to promote sound and sustainable development, shall cooperate in the field of } \\
\text { environment. Cooperative activities under this Article may include: } \\
\text { (b) Promotion of capacity and institutional building to foster activities related with the } \\
\text { Clean Development Mechanism under the Kyoto Protocol to the United Nations } \\
\text { Framework Convention on Climate Change, as may be amended, by means of } \\
\text { workshops and dispatch of experts, and exploration of appropriate ways to encourage }\end{array}$ \\
\hline
\end{tabular}

${ }^{99}$ Meltzer (n 67) 22; see also Rod Janssen, 'Harmonising Energy Efficiency Requirements - Building Foundations for Co-operative Action' (November 2010) Issue Paper No 14, International Centre for Trade and Sustainable Development.

100 Paris Agreement (n 6) Art. 9.

101 ibid, art. 10.

102 ibid, art. 11.

103 EU-Central America Association Agreement (signed 29 June 2012, entered into force 2013) <http://trade.ec.europa.eu/doclib/press/index.cfm?id=689> accessed 17 November 2016, art.63.

${ }^{104}$ Markus W Gehring and others, 'Climate Change and Sustainable Energy Measures in Regional Trade Agreements' (August 2013) Issue Paper No 3, International Centre for Trade and Sustainable Development. 


\begin{tabular}{|l|l|}
\hline EU-Singapore & $\begin{array}{l}\text { the implementation of the Clean Development Mechanism projects; } \\
\text { (c) Encouragement of trade and dissemination of environmentally sound goods and } \\
\text { services" } 105 \text { (Art. 147) }\end{array}$ \\
\hline $\begin{array}{l}\text { "The Parties agree to cooperate with a view to supporting the implementation of the } \\
\text { commitments and obligations undertaken under this Chapter. Areas of cooperation } \\
\text { include, but are not limited to, the following activities: }\end{array}$ \\
$\begin{array}{l}\text { (d) Capacity-building and technical cooperation in relation, but not limited, to: ... } \\
\text { facilitation of industry collaborations, including on intellectual property rights that may } \\
\text { be applied towards environmental conservation or enhancement which may include } \\
\text { establishing a platform or database; and public private partnerships to support culture } \\
\text { and innovation; } \\
\text { (e) Exchange of information and cooperation on intellectual property issues, where } \\
\text { appropriate and relevant to developments in environmentally friendly technology"106 } \\
\text { (Art.11.52) }\end{array}$ \\
\hline CETA & $\begin{array}{l}\text { Cooperation on environmental issues } \\
\text { " The Parties commit to cooperate on trade-related environmental issues of common } \\
\text { interest, in areas such as (e) trade-related aspects of the current and future ... } \\
\text { domestic climate policies and programmes relating to mitigation and adaptation, } \\
\text { including issues relating to carbon markets, ways to address adverse effects of trade } \\
\text { on climate, as well as means to promote energy efficiency and the development and } \\
\text { deployment of low-carbon and other climate-friendly technologies." (Art.24.11) }\end{array}$ \\
\hline
\end{tabular}

International cooperation mechanisms will allow developing countries to diversify their economies by creating market opportunities for green goods and services, promoting green energy production and consumption, producing electricity using renewable energy resources, developing green infrastructure. This will reformulate the economic growth agenda of developing countries by linking long-term sustainable development - including climate change concerns - with short term economic and trade policy priorities.

\subsection{Exceptions allowing the implementation of response measures}

In addition to incorporating climate related measures in FTAs, trade agreements include trade exceptions allowing states to adopt domestic measures for the implementation of climate change commitments. These exceptions are essential for the implementation of trade related response measures adopted by states in their INDCs/NDCs and FTAs. Some bilateral and regional trade

\footnotetext{
105 Agreement between Japan and the United Mexican States dor the Strengthening of the Economic Parternship (signed 17 September 2004, entered into force 1 April 2005) $<$ http://www.mofa.go.jp/policy/economy/fta/mexico.html> accessed 18 December 2016, art.147.

${ }^{106}$ EU-Singapore (n 75) art.11.52.
} 
agreements have adopted general exceptions similar to those included in the WTO agreements; ${ }^{107}$ others have expanded the general exceptions norm to permit a higher level of environmental protection. For instance:

\begin{tabular}{|l|l|}
\hline Agreement & Relevant Provision \\
\hline CETA & $\begin{array}{l}\text { "The Parties understand that the measures referred to in Article XX(b) of the GATT } \\
1994 \text { include environmental measures necessary to protect human, animal or plant life } \\
\text { or health. The Parties understand that Article XX(g) of the GATT 1994 applies to } \\
\text { measures for the conservation of living and non-living exhaustible natural } \\
\text { resources." }\end{array}$ \\
\hline
\end{tabular}

These general and specific exceptions allow states to implement trade-related response measures which modify market conditions in favor of green industries, ${ }^{109}$ given that such measures are not "applied in a manner which would constitute a means of arbitrary or unjustifiable discrimination between countries." ${ }^{110}$ Trade agreements also allow the possibility to derogate from the regular adoption of a TBT measure in case of environmental emergency. ${ }^{111}$ For example:

\begin{tabular}{|l|l|}
\hline Agreement & Relevant Provision \\
\hline Canada-Peru & $\begin{array}{l}\text { "Each Party shall ensure that transparency procedures regarding the development of } \\
\text { technical regulations and conformity assessment procedures allow interested parties to } \\
\text { participate at an early appropriate stage when amendments can still be introduced and } \\
\text { comments taken into account, except where urgent problems of safety, health, } \\
\text { environmental protection or national security arise or threaten to arise. Where a } \\
\text { consultation process on the development of technical regulations and conformity } \\
\text { assessment procedures is open to the public, each Party shall permit persons of the } \\
\text { other Party to participate on terms no less favourable than those accorded to its own } \\
\text { persons."112 (Art. 608) }\end{array}$ \\
\hline
\end{tabular}

The incorporation of trade exceptions in FTAs is essential to implement response measures related to climate change mitigation. To avoid inconsistency with trade obligations, states can invoke the relevant exceptions and have a leeway to adopt legitimate policy purposes regarding the promotion of renewable energy and energy efficiency. Therefore, to support climate action, states can

\footnotetext{
${ }^{107}$ Marrakesh Agreement Establishing the World Trade Organization (signed 15 April 1994) 1867 UNTS 187, 33 ILM 1153, Annex 1A, General Agreement on Tariffs and Trade 1994, Article XX(g).

${ }^{108}$ EU-Canada (n 74) art.28.3.

${ }^{109}$ Codebook, 35. According to the Codebook, 122 trade agreements include the exclusion of environmentally harmful inventions from patentability and the use of geographical indications to protect the environment.

${ }^{110}$ Marrakash Agreement (n 109) Annex 1A, GATT, art. XX chapeau.

${ }_{111}$ Codebook, 33. According to the Codebook, 231 trade agreements include the right to derogate.

${ }^{112}$ Canada-Peru (n 69) art. 608.
} 
either include climate-related measures into their FTAs or provide a list of general or specific exceptions that allow for the adoption of climate change policies. 


\section{Conclusion}

This study is divided into three parts. First, it uncovers the typology of response measures included in INDCs/NDCs submitted by the Parties to the United Nations Framework Convention on Climate Change. Second, it shows that response measures have the potential to become important policy tools used by states to promote economic diversification. Finally, it argues that to undertake their effective implementation, response measures ought to be incorporated into FTAs to support economic diversification and ensure the mutual supportiveness between trade rules and climate change obligations.

Chapter 2 maps 163 INDCs/NDCs submitted by the Parties to the United Nations Framework Convention on Climate Change to identify and categorize response measures that interact with the world trading system. These measures are classified as follows:

- Measures related to the energy sector

- Green industrial policies

- Green government procurement

- Financial and direct trade measures

- International cooperation

A number of results are identified from the mapping exercise. First, a major divide can be drawn between developed and developing countries when designing their response mearures. Developed countries use very generic wording, and their INDCs/NDCs are relatively shorter compared to other countries whereas developing countries have longer pledges and more detailed and specific commitments. Second, the parties provide a variety of financial and direct trade measures to achieve their intended targets specified in their pledges, including, inter alia, taxes, subsidies, carbon pricing mechanisms, FITs and Renewable Portfolio Standards (RPS), tariffs, import bans, and investments in R\&D. Lastly, the effect of these measures on the world trading system depends mostly on the way of their domestic implementation and on their consistency with international trade rules.

Chapter 3 builds upon the mapping of response measures examined in Chapter 2 and evaluates such commitments against the long-standing UNFCCC work streams on economic diversification. First, this chapter identifies the potential for the measures contained in the INDCs/NDCs to positively contribute to economic diversification, and how the mutual supportiveness between trade will be necessary for such potential. Second, it finds that the adverse impacts arising from the implementation of response measures are strictly related to the degree of economic 
diversification experienced by the affected country, and might entail domestic as well as cross-border effects. For instance, fossil-fuel producing countries, countries exporting carbon-intensive goods and services, and tourism-dependent countries will be impacted due to structural changes in the demand for, and prices of, the products and services which comprise the bulk of their exports, as well as in the wider regulatory environment. Lastly, the analysis suggests that there is certainly scope for the current INDCs/NDCs to promote diversification, particularly in the countries where the measures are implemented, whilst the evidence for cross-border effects is more mixed.

Finally, Chapter 4 anaylizes the possibility for FTAs to serve as positive drivers for the implementation of the INDCs/NDCs at the national and regional level. First, the Chapter identifies the following climate-related commitments in existing FTAs, suggesting an increasing incorporation of response measures into the international trading regime:

- Policies promoting the production and trade in environmental goods and services

- Subsidy Reform for green energy and development

- Standards, Technical Regulations and Conformity Assessment

- International Cooperation

Second, the Chapter argues that FTAs offer a useful venue to strengthen climate commitments and sometimes to achieve more stringent and more precise obligations on states compared to multilateral environmental agreements. Therefore, the most pressing challenge when designing FTAs appears to be that of finding a balance between promoting trade liberalization on the one hand and allowing a policy space for countries to implement their obligations under the UNFCCC on the other, in order to ensure that trade rules positively contribute to, rather than undermine, the overarching objectives of climate change mitigation and economic diversification.

Overall, the study shows the potential impact of the response measures contained in the INDCs/NDCs on economic diversification and describes how policies aimed at creating new markets, new jobs, and new innovative technologies to implement climate change obligations will lead to economic growth, especially for developing countries. In addition, the study provides an overview of the different trade-related response measures adopted by countries in their INDCs/NDCs and their interactions with the broader framework of international trade rules. Recent discussions on this topic have been ongoing at the UNFCCC level, suggesting that the relationship between trade and climate change is finally established and it is here to stay. However, further research is needed to delve deeper into this interaction, in order to offer best practice models for domestic implementation of climate change commitments as well as informing future developments in the field of international trade. 


\section{Bibliography}

\section{Books and Articles:}

Bacchus J, 'Global Rules for Mutually Supportive and Reinforcing Trade and Climate Regimes' (2016) E15 Expert Group on Measures to Address Climate Change and the Trade System - Policy Options Paper, E15Initiative, International Centre for Trade and Sustainable Development and World Economic Forum.

Bagnoli $P$, Chateau $\mathrm{J}$ and Kim YG, 'The Incidence of Carbon Pricing: Norway, Russia and the Middle East' (2008) OECD Journal: Economic Studies No.44, 2008/1 <http://www.oecd.org/eco/42505369.pdf> accessed 19 November 2016

CDKN and Ricardo-AEA, 'A Guide to INDCs' (2 ${ }^{\text {nd }}$ Edition, May 2015) <http://cdkn.org/wpcontent/uploads/2015/04/CDKN-Guide-to-INDCs-Revised-May2015.pdf> accessed 19 October 2016;

Clapp J, 'What the Pollution Havens Debate Overlooks' (2002) 2(2) Global Environmental Politics 11

Cosbey A and Tarasofsky R, Climate Change, Competitiveness and Trade. A Chatham House Report (Chatham House 2007)

Das K and Bandyopadhyay KR, Climate Change and Clean Energy in the 2030 Agenda: What Role for the Trade System? (ICSTD 2016)

Dutt P, Mihov I and Van Zandt T, 'Trade Diversification and Economic Development' (28 October 2008) Mimeo, INSEAD

Edquist $\mathrm{C}$ and Zabala-Iturriagagoitia JM, 'Public Procurement for Innovation as Mission-oriented Innovation Policy' (2012) 41 Research Policy 1757

European Commission, DG ENER Working Paper: The Future Role and Challenges of Energy Storage, <https://ec.europa.eu/energy/sites/ener/files/energy_storage.pdf> accessed 19 Dec. 2016;

Granoff I, 'Trade Implications of Climate Policy after the Paris Outcome' (2016) Commonwealth Trade Hot Topics Issue $130<$ http://www.oecd-ilibrary.org/fr/commonwealth/trade/trade-implications-of-climatepolicy-after-the-paris-outcome 5j|wz7lt4k9q-en> accessed 12 October 2016

George C, 'Environment and Regional Trade Agreements' (2013) (OECD Trade and Environment Working Papers 2013/04 <http://www.oecd-ilibrary.org/content/workingpaper/5jz0v4q45g6h-en> accessed 23 November 2016

Gehring MW and others 'Climate Change and Sustainable Energy Measures in Regional Trade Agreement' (August 2013) Issue Paper No 3, International Centre for Trade and Sustainable Development

Hare PG, 'Institutions and Diversification of the Economies in Transition' in Rob Vos and Malinka Koparanova (eds) Globalization and Economic Diversification (Bloomsbury Academic 2011)

Höhne N, Ellermann E and Fekete H, 'Process Guidance for Intended Nationally Determined Contributions' (International Partnership on Mitigation and MRV Knowledge Product, November 2014) < https://mitigationpartnership.net/sites/default/files/ipmm 2014 process guidance for intended nationall $y$ determined contributions indcs.pdf > accessed 19 October 2016

Howse R and Van Bork P, 'Options for Liberalising Trade in Environmental Goods in the Doha Round' (Issue Paper No 2, International Centre for Trade and Sustainable Development, July 2006)

Intergovernmental Panel on Climate Change, Climate Change 2007: Synthesis Report (UNFCCC 2007) $<$ https://www.ipcc.ch/publications and data/ar4/syr/en/mains1.html> accessed 18 November 2016.

International Energy Agency, Issues behind Competitiveness and Carbon Leakage: Focus on Heavy Industry (IEA information paper, IEA 2008).

Janssen R, 'Harmonising Energy Efficiency Requirements - Building Foundations for Co-operative Action' (Issue Paper No 14, International Centre for Trade and Sustainable Development, November 2010). 
Keane J, 'Diversifying Exports in the Context of Climate Change' (April 2011) Overseas Development Institute Background Paper <http://www.odi.org/sites/odi.org.uk/files/odi-assets/publications-opinionfiles/7090.pdf> accessed 19 September 2016

Levin K and others, 'Designing and Preparing Intended Nationally Determined Contributions' (World Resources Institute 2015) < http://www.wri.org/sites/default/files/designing-preparing-indcs-report.pdf> accessed 19 October 2016

Meltzer J, 'The Trans-Pacific Partnership Agreement, the environment and climate change ' in Tania Voon (ed) Trade and Liberalization and International Co-operation: A legal Analysis of the Trans-Pacific Partnership Agreement (Edward Elgar 2014)

Merrill L, Bassi AM, Bridle R and Christensen LT, 'Tackling Fossiel Fuel Subsidies and Climate Change: Levelling the Energy Playing Field' (Nordic Council of Ministers 2015) <http://www.greengrowthknowledge.org/sites/default/files/downloads/resource/Tackling Fossil Fuel Su bsidies and Climate Change Levelling the Energy Playing Field Nordic Concil of Ministers.pdf> accessed 10 December 2016

Moise E and Steenblik R, 'Trade-Related Measures Based on Processes and Production Methods in the Context of Climate-Change Mitigation' (Trade and Environment Working Paper No 2011/04, Organisation for Economic Co-operation and Development, 3 August 2011).

Morin J, 'TREND TRade and ENvironment Database Codebook' (July 2016) <http://www.chaireepi.ulaval.ca/sites/chaire-epi.ulaval.ca/files/codebook public july.pdf > accessed 17 November 2016.

Morin J, Michaud N, Bialais C, 'Trade negotiations and Climate Governance, the EU as a frontrunner but not yet a leader' Issue Briefs N¹0/2016. IDDRI, 2016 4.P <http://www.iddri.org/Publications/Les-negociationscommerciales-et-la-gouvernance-climatique-I-UE-comme-precurseur,mais-pas-(encore)-meneur> accessed 13 December 2016

Neumayer E, 'Pollution Havens: Do Developing Countries Set Inefficient Environmental Standards to Attract Foreign Investment?' in Eric Neumayer, Greening Trade and Investment: Environmental Protection Without Protectionism (Earthscan 2001)

__ 'Pollution Havens: An Analysis of Policy Options for Dealing with an Elusive Phenomenon' (2001) 10(2) Journal of Environment and Development

Nourse HO, Regional Economics: a Study in the Economic Structure, Stability, and Growth of Regions (McGrawHill 1968)

OECD, 'The Impact of Trade Liberalisation on Jobs and Growth' (2011) OECD Trade Policy Paper No. 107 <http://www.oecd-ilibrary.org/trade/the-impact-of-trade-liberalisation-on-jobs-and-growth $5 \mathrm{kgj} 4 \mathrm{ffj} 1 \mathrm{nq2}$-e>> accessed 24 November 2016.

Pauwelyn J, 'Carbon Leakage Measures and Border Tax Adjustments Under WTO Law' in Geert Van Calster and Denise Prévost (eds) Research Handbook on Environment, Health and WTO (Edward Elgar 2013).

Stavins RN and others, 'International Cooperation: Agreements and Instruments' in Ottmar Edenhofer and others (eds) Climate Change 2014: Mitigation of Climate Change. Contribution of Working Group III to the Fifth Assessment Report of the Intergovernmental Panel on Climate Change (Cambridge University Press 2014)

Steenblik R, 'Environmental Goods: A Comparison of the APEC and OECD Lists' (29 November 2005) OECD Trade and Environment Working Paper No 2005-04.

Taglioni D and Winkler D, Making Global Value Chains Work for Development (Trade and Development Series, World Bank Group 2016)

UNFCCC, 'Report of the Conference of the Parties on its nineteenth session, held in Warsaw from 11 to 23 November 2013. Addendum. Part two: Action taken by the Conference of the Parties at its nineteenth session' (31 January 2014) UN Doc FCCC/CP/2013/10/Add.1.

'The concept of economic diversification in the context of response measures. Technical Paper by the Secretariat' (6 May 2016) UN Doc FCCC/TP/2016/3 
'Improved Forum and Work Programme. Revised Draft Conclusions Proposed by the Chairs' (26 May 2016) UN Doc FCCC/SB/2016/L.2/Rev.1.

'Just Transition of the Workforce, and the Creation of Decent Work and Quality Jobs. Technical Paper by the Secretariat' (26 October 2016) UN Doc FCCC/TP/2016/7

'Report by the Chairs of the Subsidiary Bodies' (28 October 2016) UN Doc FCCC/SB/2016/INF.2

Vollenbergh HRJ and Van der Werf E, 'The Role of Standards in Eco-Innovation: Lessons for Policymakers' (2014) 8(2) Review of Environmental Economics and Policy

Warner M, Local Content in Procurement: Creating Local Jobs and Competitive Domestic Industries in Supply Chains (Greenleaf 2011)

Wold C, Gourlie D and Schlusser A, 'Climate Change, International Trade, and Response Measures: Options for Mitigating Climate Change Without Harming Developing Country Economies' (2014) 46 The George Washington International Law Review

Wu M, 'Why Developing Countries Won't Negotiate: The Case of the WTO Environmental Goods Agreement (2014) 6(1) Trade Law \& Development

\section{International Treaties and FTAs:}

Canada-Colombia agreement on the environment (signed 21 November 2008, entered into force 15 August 2011) <https://www.ec.gc.ca/caraib-carib/default.asp?lang=En\&n=FFEF249E-1> accessed 19 November 2016.

Canada-Peru Free Trade Agreement (signed 29 May 2008, entered into force 1 August 2009) $<$ http://www.international.gc.ca/trade-agreements-accords-commerciaux/agr-acc/peru-perou/peru-tocperou-tdm.aspx?lang=eng >

European Union-Canada Comprehensive Economic and Trade Agreement (signed on 30 October 2016, not yet in force) <http://ec.europa.eu/trade/policy/in-focus/ceta/ceta-chapter-by-chapter/> accessed 12 December 2016.

European Union-CARIFORUM States Economic Partnership Agreement (signed 15 October 2008, provisional application began $29 \quad$ December 2008 ) lex.europa.eu/LexUriServ/LexUriServ.do?uri=OJ:L:2008:289:0003:1955:EN:PDF> $\quad$ accessed 18 November 2016.

European Union-Central America Association Agreement (signed 29 June 2012) <http://trade.ec.europa.eu/doclib/press/index.cfm?id=689> accessed 17 November 2016.

European Union-Colombia/Peru Free Trade Agreement (signed 26 June 2012, entered into force 1 June 2013) < http://trade.ec.europa.eu/doclib/press/index.cfm?id=689> accessed 9 January 2017.

European Union-Georgia Free Trade Agreement (signed 27 June 2014, entered into force 1 July 2016) <http://eur-lex.europa.eu/legal-content/EN/TXT/PDF/?uri=CELEX:22014A0830(02)\&from=EN> accessed 14 December 2016

European Union-South Korea Free Trade Agreement (signed 23 May 2009, entered into force 11 July 2011) $<$ <ttp://ec.europa.eu/trade/policy/countries-and-regions/countries/south-korea/> accessed 20 December 2016

European Union-Singapore Free Trade Agreement (signed 17 October 2016, not yet in force) $<$ http://trade.ec.europa.eu/doclib/docs/2013/september/tradoc 151766.pdf> accessed 14 November 2016.

Japan-Mexico Agreement between Japan and the United Mexican States for the Strengthening of the Economic Parternship (signed 17 September 2004, entered into force 1 April 2005) <http://www.mofa.go.jp/policy/economy/fta/mexico.html> accessed 18 December 2016

Marrakesh Agreement Establishing the World Trade Organization (15 April 1994) 1867 UNTS 187, 33 ILM. 1153 
Morocco-United States Free Trade Agreement (signed 15 June 2004, entered into force 1 January 2006) $<$ https://ustr.gov/trade-agreements/free-trade-agreements/morocco-fta $>$ accessed 9 December 2016

New Zealand-Taiwan Free Trade Agreement, Agreement between New Zealand and the Separate Customs Territory of Taiwan, Penghu, Kinmen, and Matsu on Economic Cooperation (signed 10 July 2013, entered into force on 1 December 2013) <http://www.nzcio.com/webfm send/59> accessed 30 November 2016

Trans-Pacific Partnership (signed 4 February 2016, not yet in force) <https://ustr.gov/trade-agreements/freetrade-agreements/trans-pacific-partnership/tpp-full-text> accessed 13 December 2016.

Treaty on the Eurasian Economic Union (signed in 29 May 2014, entered into force on 1 January 2015) $<$ http://www.un.org/en/ga/sixth/70/docs/treaty on eeu.pdf> accessed 19 December 2016

United States-Chile Free Trade Agreement (signed 6 June 2003, entered into force 1 January 2004) <https://ustr.gov/trade-agreements/free-trade-agreements/chile-fta> accessed 19 December 2016

United States-Korea Free Trade Agreement (signed 30 June 2007, entered into force 15 March 2012) $<$ https://ustr.gov/trade-agreements/free-trade-agreements/korus-fta> accessed 15 December 2016 


\section{Annex 1: Country Summaries}




\section{GHG and non-GHG target}

- Afghanistan commits to a $13.6 \%$ reduction in GHG emissions by 2030 compared to a BAU scenario, conditional on external support.

\section{Measures related to the energy sector}

- Provision and development of alternative and renewable energy sources for $25 \%$ of the rural population above existing levels (15\%) (conditional).

- Cleaner coal mining, leave-it-in-the-ground approaches, combustion, and transportation of minerals (conditional).

\section{Green industrial policies}

- The INDC explicitly covers energy efficiency, industrial processes, extractive industries, and transportation sectors.

- Building codes, standards on appliances and equipment (conditional).

- Environmental compliance standards (emissions and indoor) (conditional).

\section{Green government procurement}

- None.

Financial and direct trade measures (subsidies, carbon pricing, taxation, R\&D etc.)

- Traditional customs and administered pricing for energy efficiency in transportation and buildings sector (conditional).

- Renewable energy, entry costs support, access to capital, and subsidies (conditional).

International cooperation (climate finance, technology transfer, international mechanisms etc.)

- All mitigation actions in the NDC are made conditional on needs for financial and technological support. 


\section{GHG and non-GHG target}

- Albania commits to reduce CO2 emissions compared to the baseline scenario in the period of 2016 and 2030 by $11.5 \%$. This reduction means 708 kT carbon- dioxide emission reduction in 2030 .

\section{Measures related to the energy sector}

- None, but the NDC explicitly covers the energy sector.

\section{Green industrial policies}

- None, but the NDC explicitly covers the industrial processes sector.

\section{Green government procurement}

- None.

Financial and direct trade measures (subsidies, carbon pricing, taxation, R\&D etc.)

- None.

\section{International cooperation (climate finance, technology transfer, international mechanisms etc.)}

- Albania intends to sell carbon credits to contribute to cost- effective implementation of the low emission development pathway and its sustainable development.

- Albania foresees that the utilization of an international market mechanism is conditional upon having effective accounting rules developed under the UNFCCC to ensure the environmental integrity of the mechanisms. 


\section{GHG and non-GHG target}

- Algeria intends to reduce greenhouse gas emission of $7 \%$ to $22 \%$ by 2030 compared to BAU levels (conditional). A 7\% reduction will be achieved by domestic means.

- By 2030, Algeria commits to the deployment, on a large scale, of photovoltaic and wind power as well as thermal solar energy, and the integration of cogeneration, biomass and geothermal energy. Ultimate target: $27 \%$ of the electricity produced nationally is derived from renewable sources of energy.

\section{Measures related to the energy sector}

- $27 \%$ of electricity generated from renewable sources of energy by 2030 .

- Reduction of the volume of gas flaring to less than $1 \%$ by 2030 .

\section{Green industrial policies}

- Increase in the share of liquefied petroleum and natural gas in the consumption of fuels between 2021 and 2030.

- Generalization of high-performance lighting.

- Thermal insulation of buildings between 2021 and 2030.

\section{Green government procurement}

- None.

Financial and direct trade measures (subsidies, carbon pricing, taxation, R\&D etc.)

- None.

International cooperation (climate finance, technology transfer, international mechanisms etc.)

- All mitigation actions are made conditional on support in terms of external finance, technology development and transfer and capacity building. 


\section{GHG and non-GHG target}

- Andorra commits to reduce GHG emissions by $37 \%$ (193.73 Gg CO2 eq.) from its BAU scenario emissions in 2030.

Measures related to the energy sector

- None, but the INDC explicitly covers the energy sector.

\section{Green industrial policies}

- None.

\section{Green government procurement}

- None.

Financial and direct trade measures (subsidies, carbon pricing, taxation, R\&D etc.)

- None.

International cooperation (climate finance, technology transfer, international mechanisms etc.)

- Andorra does not envisage any contribution from international market mechanisms to meet its commitments under the INDC. 


\section{GHG and non-GHG target}

- Angola plans to reduce GHG emissions up to $35 \%$ unconditionally by 2030 as compared to the BAU scenario (base year 2005). In addition, it is expected that through a conditional mitigation scenario the country could reduce an additional 15\% below BAU emission levels by 2030.

- In achieving its targets Angola expects to reduce its emissions trajectory by nearly $50 \%$ below the BAU scenario by 2030 at overall cost of over 14.7 billion USD.

\section{Measures related to the energy sector}

- Expansion of the installed capacity to the existing Cambambe Hydroelectric Power Plant, from $180 \mathrm{MW}$ to the current $260 \mathrm{MW}$.

- Capacity addition to the existing Cambambe Hydroelectric Power Plant with installation of additional $700 \mathrm{MW}$ of the actual generation capacity.

- Wind energy conversion of Tombwa Wind Farm into electrical energy. Energy generated will be a result of a total installed capacity of $100 \mathrm{MW}$ and will produce power through 50 wind turbines, with a rated individual potency of $2 \mathrm{MW}$.

- Development of the production of ethanol as an alternative to fossil fuels.

\section{Green industrial policies}

- None.

\section{Green government procurement}

- None.

Financial and direct trade measures (subsidies, carbon pricing, taxation, R\&D etc.)

- None.

International cooperation (climate finance, technology transfer, international mechanisms etc.)

- Angola will pursue international support to utilize existing and emerging climate finance mechanisms and will encourage investments in green growth development initiatives to develop a portfolio of renewable energy projects identified by the Angolan government.

- Angola recognizes the role that a carbon market can play for the mobilization of resources and promotion of development and transfer of climate friendly technology. 


\section{GHG and non-GHG target}

- Antigua and Barbuda commits to enhancing the established enabling legal, policy and institutional environment for a low carbon emission development pathway to achieve poverty reduction and sustainable development.

\section{Measures related to the energy sector}

- By 2030, Antigua and Barbuda will achieve an energy matrix with $50 \mathrm{MW}$ of electricity from renewable sources both on and off-grid in the public and private sectors (conditional).

- By 2020, finalizing the technical studies with the intention to construct and operationalize a waste to energy (WTE) plant by 2025 (conditional).

\section{Green industrial policies}

- By 2020, Antigua and Barbuda intends to establish efficiency standards for the importation of all vehicles and appliances (conditional).

\section{Green government procurement}

- None.

Financial and direct trade measures (subsidies, carbon pricing, taxation, R\&D etc.)

- None.

\section{International Cooperation (climate finance, technology transfer, international mechanisms etc.)}

- The conditional adaptation and mitigation targets presented in this NDC are contingent upon Antigua and Barbuda receiving international support for capacity building, technology transfer and financial resources, including through the Green Climate Fund (GCF), the Global Environment Facility (GEF), the Adaptation Fund and multilateral agencies and bilateral agreements.

- Antigua and Barbuda considers the establishment of an international market mechanism as an important complementary option to reduce total costs associated with limiting GHG emissions and to assist global efforts. Antigua and Barbuda acknowledges the potential for a renewed and reformed Clean Development Mechanism. 


\section{GHG and non-GHG target}

- Argentine intends to reduce GHG emissions by $15 \%$ in 2030 with respect to projected BAU emissions for that year.

- Reduction could be increased to $30 \%$ by 2030 compared to projected BAU emissions in the same year, conditional upon adequate and predictable international financing; support for transfer, innovation and technology development; and support for capacity building.

Measures related to the energy sector

- None, but the INDC mentions actions on biofuels, nuclear power, renewable energy.

\section{Green industrial policies}

- None, but the INDC mentions actions on energy efficiency and biofuels shift.

\section{Green government procurement}

- None.

Financial and direct trade measures (subsidies, carbon pricing, taxation, R\&D etc.)

- None.

International cooperation (climate finance, technology transfer, international mechanisms etc.)

- None. 


\section{GHG and non-GHG target}

- Armenia states that its total aggregate emissions between 2015 and 2050 will be equal to 633 million tons of carbon dioxide equivalent.

- Armenia states that the country will strive to achieve ecosystem neutral GHG emissions in 2050 (equivalent to 2.07 tons/per capita per annum) with the support of adequate (necessary and sufficient) international financial, technological and capacity building assistance.

\section{Measures related to the energy sector}

- None, but the INDC explicitly covers the energy sector.

\section{Green industrial policies}

- None, but the INDC explicitly covers urban development, industrial processes, and transport.

\section{Green government procurement}

- None.

Financial and direct trade measures (subsidies, carbon pricing, taxation, R\&D etc.)

- Creation of a climate revolving civil fund, to be replenished on permanent base by allocations from environmental fees, ecosystem service fees, including "carbon taxing".

\section{International cooperation (climate finance, technology transfer, international mechanisms etc.)}

- Establishment of institutional mechanisms to overcome barriers for the introduction of innovative technologies for climate change mitigation and adaptation, including strengthening the system of legal protection of intellectual property rights.

- Armenia needs to ensure an open and transparent system of technology introduction and transfer as a contribution to the INDC, such as through the cooperation and experience exchange with "Climate Technology Center and Network" (CTCN) and through the establishment of a similar mechanism in the country (ArmCTCN).

- Utilization of international financial mechanisms with resource provision following the principle of additionality, such as the Green Climate Fund, the Adaptation Fund, the Global Environmental Facility, bilateral and multilateral funds, and other sources. 


\section{GHG and non-GHG target}

- Australia commits to implementing an economy-wide target to reduce greenhouse gas emissions by 26 to $28 \%$ below 2005 levels by 2030 .

\section{Measures related to the energy sector}

- Enhanced management of synthetic greenhouse gas emissions under ozone protection laws and the Montreal Protocol.

- Renewable Energy Target scheme. According to the scheme, over $23 \%$ of Australia's electricity will come from renewable sources by 2020 .

\section{Green industrial policies}

- National Energy Productivity Plan, with a National Energy Productivity Target of a $40 \%$ improvement between 2015 and 2030.

- Investigation of opportunities to improve the efficiency of light and heavy vehicles.

\section{Green government procurement}

- None.

Financial and direct trade measures (subsidies, carbon pricing, taxation, R\&D etc.)

- Australia's Emissions Reduction Fund in place since 2015 to support businesses to reduce emissions while improving productivity. New safeguard mechanism to be finalised to ensure emissions reductions purchased under the Fund are not offset by significant rises in emissions elsewhere in the economy.

International cooperation (climate finance, technology transfer / international mechanisms etc.)

- None. 


\section{GHG and non-GHG target}

- By 2030 the Republic of Azerbaijan commits to reduce $35 \%$ in the level of greenhouse gas emissions compared to 1990 base year.

\section{Measures related to the energy sector}

- Application of environmental-friendly technologies in the oil and gas processing and production of fuel in line with EURO-5 standards in a new refinery complex by 2019.

- Modernization of gas pipelines, gas distribution system and other measures to decrease losses up to $1 \%$ by 2020 and ensure the volume of reduction in compliance with international standards by 2050 .

- Replacement of existing technologies in electricity and thermal energy production with modern technologies.

- Reconstruction of the distribution networks and transmission lines.

- Acceleration of works to supply renewable energy for heating systems, enhancement of use of innovative technologies, construction of small hydro power plants (HPPs) on small rivers, irrigation canals and water basins.

- Use of biomass, solar power, electric and heat energy, wind power, heat pumps and geothermal energy in all sectors of economy.

\section{Green industrial policies}

- None.

\section{Green government procurement}

- None.

Financial and direct trade measures (subsidies, carbon pricing, taxation, R\&D etc.)

- None.

International cooperation (climate finance, technology transfer, international mechanisms etc.)

- None. 


\section{GHG and non-GHG target}

- The Bahamas intends to implement an economy-wide reduction in GHG emission of $30 \%$ when compared to its BAU scenario by 2030.

- A minimum of $30 \%$ renewables in the energy mix by 2030 and a $10 \%$ Residential Energy Self Generation Programme within the year.

\section{Measures related to the energy sector}

- None, but the NDC explicity covers the energy sector.

\section{Green industrial policies}

- Supporting legislation and infrastructure for use of biofuels.

- Energy efficiency standards outlined in an energy-efficiency building code.

\section{Green government procurement}

- None.

Financial and direct trade measures (subsidies, carbon pricing, taxation, R\&D etc.)

- Through Public Private Partnerships and government funding, The Bahamas will focus on the development of indigenous renewable energy resources.

- The transport sector strategy will discourage the importation of inefficient motor vehicles by linking the tax regime to mileage per gallon and the engine capacity.

- Programme of incentives and fiscal measures to enable and support investments in modern facilities and infrastructure in the energy sector, energy efficiency, and conservation initiatives.

- Incentives and fiscal measures for the further advancement of renewable energy options.

- Financial measures related to environmental goods and services

$\circ$ The Bamahas will lower import duties on hybrid and electric cars.

International cooperation (climate finance, technology transfer, international mechanisms etc.)

- None. 
GHG and non-GHG target

- None.

Measures related to the energy sector

- BAPCO project consisting of the installation of 21,000 smart solar panels to generate a substantial number of Kwhs of electricity annually. The 5MW PV grid-connected plant aims at demonstrating PV solar technology under local conditions to support up scaling of renewable energy.

- Construction of an electricity and Water Authority 5MW grid-connected pilot power plant from solar/wind sources.

- Implementation of BAPCO Carbon Recovery Plan to utilize waste CO2 to be used for industrial applications.

- Implementation of Gulf Petrochemical Industries Company (GPIC) Carbon Recovery Project to capture $\mathrm{CO} 2$ in the gases of the GPIC Methanol Plant.

\section{Green industrial policies}

- Civil Aviation Authority - Emission Management Plan for Sustainable Aviation Growth, including an aviation efficiency program.

- Kingdom of Bahrain Energy Efficiency Programme (KEEP) targets residential and commercial buildings and the industrial sector. It aims to improve energy efficiency to reduce cumulative electricity consumption by 2030.

- Adoption of the Motor Vehicles Standards and technical regulations to reduce the emissions from gasoline and diesel engine vehicles.

\section{Green government procurement}

- Kingdom of Bahrain Energy Efficiency Programme (KEEP) also applies to public buildings.

Financial and direct trade measures (subsidies, carbon pricing, taxation, R\&D etc.)

- None.

\section{International cooperation (climate finance, technology transfer, international mechanisms etc.)}

- Mitigation and adaptation on the part of Bahrain are meant to inform and will be undertaken in the context of support on finance, technology-transfer and capacity building. 


\section{GHG and non-GHG target}

- Unconditional contribution to reduce GHG emissions by 5\% from BAU levels by 2030 in the power, transport and industry sectors, based on existing resources.

- A conditional 15\% reduction in GHG emissions from BAU levels by 2030 in the power, transport, and industry sectors, subject to appropriate international support.

- Further mitigation actions in other sectors, conditional on additional international resources.

\section{Measures related to the energy sector}

- Ensure all new coal generation uses super-critical technology (100\% by 2030 ).

- Increased penetration of wind power (400MW by 2030) and implementation of a 1000MW gridconnected solar plant to diversify the existing electricity generation mix.

- Solar Homes Programme, providing off-grid electricity access to rural areas.

- Plan to scale up the potential of Solar Irrigation Pumps, Solar mini and nano grids to address the energy access issue of off-grid population.

\section{Green industrial policies}

- Energy audits to incentivise the uptake of energy efficiency and conservation measures in the main industrial sectors $(10 \%$ reduction of energy consumption in industry sector compared to BAU by 2030).

- Promotion of policies to induce greater level of energy efficiency and conservation in the commercial sector (25\% reduction of energy consumption in the sector compared to BAU by 2030).

- An Energy Efficiency labelling programme to promote sales of high efficiency products in the market.

- A revised code on energy efficiency of new buildings.

\section{Green government procurement}

- Solar roof-top program, with around $14 \mathrm{MW}$ of solar installed on the vacant roof-tops of Government and private buildings.

Financial and direct trade measures (subsidies, carbon pricing, taxation, R\&D etc.)

- None.

International cooperation (climate finance, technology transfer, international mechanisms etc.)

- International support sought in the form of finance, investment, technology development and transfer, and capacity building. 


\section{GHG and non-GHG target}

- Barbados intends to achieve an economy-wide reduction in GHG emissions of $44 \%$ compared to its BAU scenario by 2030. In absolute terms, this translates to a reduction of $23 \%$ compared with the baseline year, 2008.

- As an interim target, an economy-wide reduction of $37 \%$ compared to its BAU scenario by 2025 , equivalent to an absolute reduction of $21 \%$ compared to 2008 .

\section{Measures related to the energy sector}

- Construction of waste-to-energy and biomass generation plants, wind, distributed and centralized solar PV and capture and use of landfill gas for energy generation.

\section{Green industrial policies}

- Barbados has recently concluded a Resource Efficient Low Carbon and Circular Industrial Partnership Platform for Catalyzing Eco-Innovation and Entrepreneurship in Barbados with UNIDO in order to advance a resource efficient green economy through inclusive and sustainable industrial development.

\section{Green government procurement}

- None.

Financial and direct trade measures (subsidies, carbon pricing, taxation, R\&D etc.)

- $\quad$ Financial measures related to environmental goods and services

$\circ$ Investment in alternative vehicles and fuels such as compressed natural gas, liquid petroleum gas, ethanol, natural gas, hybrid and electric. Adoption is encouraged through tax incentives.

- Major contributions by the private sector in installing solar PV and other renewable energy in response to global energy prices, declining renewable energy technology costs and government fiscal incentives.

\section{International cooperation (climate finance, technology transfer, international mechanisms etc.)}

- Barbados will require significant financial, technology transfer and capacity-building support to deliver the intended contribution and related infrastructure. International grant and loan financing mechanisms such as the existing 'Energy Smart Fund' will be imperative to provide financial and technical support to renewable energy and energy efficiency projects. A number of the planned renewable energy projects provide a strong economic argument to stimulate private sector investment; however, enabling and technology transfer support will still be required. 


\section{GHG and non-GHG target}

- Belarus commits by 2030 to reduce GHG emissions by at least $28 \%$ compared to 1990 levels, excluding emissions and removals in the LULUCF sector and without any additional conditions.

\section{Measures related to the energy sector}

- None, but the NDC explicity covers the power industry.

\section{Green industrial policies}

- None, but the NDC explicitly covers industrial processes.

\section{Green government procurement}

- None.

Financial and direct trade measures (subsidies, carbon pricing, taxation, R\&D etc.)

- None.

International cooperation (climate finance, technology transfer, international mechanisms etc.)

- The Republic of Belarus will support developing countries in capacity building and in the area of research and development relating to climate change issues.

- The Republic of Belarus explicitly states that its commitments do not imply the use of international carbon market mechanisms or the mobilization of foreign financial resources. 
GHG and non-GHG target

- None.

\section{Measures related to the energy sector}

- Sustainable Energy Strategy and Action Plan, setting an objective of $85 \%$ renewable energy by 2030 by implementing hydropower, solar, wind and biomass, and reduction of transmission and distribution losses. The plan envisions a reduction in energy intensity per capita at least by $30 \%$ by 2033 and to reduce fuels imports dependency by $50 \%$ by 2020 using renewable energy.

- National Solid Waste Management Strategy and Plan, aiming to reduce methane emissions by capping and closing open dumps, capturing and utilizing landfill gas, and ensuring proper waste handling and organics management.

\section{Green industrial policies}

- None.

\section{Green government procurement}

- None.

Financial and direct trade measures (subsidies, carbon pricing, taxation, R\&D etc.)

- None.

International cooperation (climate finance, technology transfer, international mechanisms etc.)

- International climate finance will be needed to implement Belize's Climate Action Plan. 


\section{GHG and non-GHG target}

- Implementation of Benin's proposed measures is likely to help reduce greenhouse gas emissions by about $21.4 \%$ relative to a BAU scenario by 2030 (excluding LULUCF). The unconditional contribution corresponds to a $3.5 \%$ GHG emissions reduction relative to the BAU scenario by 2030 . The conditional contribution would allow for an additional emissions reduction of $17.9 \%$.

\section{Measures related to the energy sector}

- Enhancement of national capacity for electric power generation and promotion of the use of natural gas and renewable energy in electricity production from (i) dual-fuel power plants (oil or natural gas) (400 MW), (ii) hydroelectric power plants (four hydroelectric plants with a total capacity of $396.6 \mathrm{MW}$ installed); (lii) solar PVs (54.2 MWp).

- Construction at the port of Cotonou of a storage and regasification unit for liquefied natural gas + connection with the pipeline.

\section{Green industrial policies}

- None.

\section{Green government procurement}

- None.

\section{Financial and direct trade measures (subsidies, carbon pricing, taxation, R\&D etc.)}

- Differential taxation for older cars used for more than five years.

- Tax exemption on mass transit vehicles.

- Tax and import duties exemption on 4T motorcycles and parts.

International cooperation (climate finance, technology transfer, international mechanisms etc.)

- Implementation of the INDC requires external assistance (bilateral or multilateral) estimated in USD 27.81 billion.

- Conditional support for scientific, technical and technological research on adaptation and mitigation of climate change. 


\section{GHG and non-GHG target}

- Bhutan intends to remain carbon neutral, with emission of greenhouse gases that will not exceed carbon sequestration by its forests.

\section{Measures related to the energy sector}

- Bhutan can offset up to 22.4 million tons of CO2e per year by 2025 in the region through the export of electricity from its clean hydropower projects.

\section{Green industrial policies}

- Improvement in the efficiency and emissions from existing vehicles through standards and capacity building.

- Improvement of manufacturing processes in existing industries through investments and adoption of cleaner technology, energy efficiency and environmental management.

- Enhancement of environmental compliance monitoring systems.

- Promotion of investment in new industries that are at higher levels in the value chain, and green industries and services.

- Promotion of industrial estate development and management in line with efficient, clean and green industry development objectives.

\section{Green government procurement}

- None.

Financial and direct trade measures (subsidies, carbon pricing, taxation, R\&D etc.)

- Financial measures related to environmental goods and services

$\circ$ Promotion of non- motorized transport and non- fossil fuel powered transport such as electric and fuel cell vehicles.

International cooperation (climate finance, technology transfer, international mechanisms etc.)

- Pursuit of sustainable and clean hydropower development with support from CDM or other climate market mechanisms to reduce emissions within Bhutan and the region by exporting surplus electricity.

- Successful implementation of intended actions to mitigate climate change will depend on the level of financial and technical support received. 


\section{GHG and non-GHG target}

- Increased participation of renewable energy to $79 \%$ by 2030 from 39\% in 2010; developing the export potential of electricity, generated mainly by renewable energies, reaching to export an estimated $8,930 \mathrm{MW}$ by 2030 , increasing energy state income.

- Increased participation of renewable energy to $81 \%$ by 2030 , compared to $39 \%$ in 2010 (conditional).

\section{Measures related to the energy sector}

- Change and diversification of the energy matrix with renewable energy growth through the construction of hydropower (small and medium hydropower plants, large hydro and multipurpose), installation of alternative energy (wind, biomass, geothermal and solar), and use other sources of energy (steam combined cycle).

- Promotion of energy surplus export from renewables sources, positioning Bolivia as a regional powerhouse with clean energy.

- Creation of large networks of power lines for transmission and distribution services coverage.

\section{Green industrial policies}

- None.

\section{Green government procurement}

- None.

Financial and direct trade measures (subsidies, carbon pricing, taxation, R\&D etc.)

- State participation in energy generation, creating income and implementing policies and redistribution of wealth.

International cooperation (climate finance, technology transfer, international mechanisms etc.)

- Bolivia could achieve additional results with the support of international cooperation and the financial mechanism of the UNFCCC, understanding cooperation as grant-based finance and technology transfer. 


\section{GHG and non-GHG target}

- Emission reduction that Bosnia-Herzegovina unconditionally might achieve, compared to the BAU scenario, is $2 \%$ by 2030 which would mean $18 \%$ higher emissions compared to the base year 1990 .

- International support would result in emission reduction of $3 \%$ compared to 1990 , which compared to the BAU scenario represents a possible reduction of $23 \%$.

\section{Measures related to the energy sector}

- Increase in share of renewable energy in electricity production.

- Construct of co-generation plants fuelled by wood chips and wood waste from wood processing industry, with total power generation capacity of $70 \mathrm{MW}$, by 2030 .

- Replacement of existing thermal power plants with $30 \%$ average efficiency with new plants with approximately $40 \%$ average efficiency.

- Installation of equipment for power generation from methane from two underground mines.

- Installation of mini hydro power plants with the power generation capacity of up to $10 \mathrm{MW}$ and the total generation capacity of $120 \mathrm{MW}$, by 2030 .

- Installation of wind farms of the power generation capacity of $175 \mathrm{MW}$ by 2030.

- Installation of photovoltaic modules of the total power generation capacity of $4 \mathrm{MW}$ by 2030

- Introduction of renewable energy sources in the existing district heating systems and construction of new district heating systems fuelled by renewable energy sources.

- Reconstruction and modernization of district heating grids, boilers and district heating substations.

\section{Green industrial policies}

- Minimal technical requirements and sanitation activities related to increase energy efficiency within the buildings sector.

\section{Green government procurement}

- Systemic energy rehabilitation of existing buildings, with a focus on public sector.

Financial and direct trade measures (subsidies, carbon pricing, taxation, R\&D etc.)

- None.

International cooperation (climate finance, technology transfer, international mechanisms etc.)

- Actions by Bosnia-Herzegovina are conditional on access to international development/financial mechanisms. 


\section{BOTSW ANA}

GHG and non-GHG target

- Botswana intends to achieve an overall emissions reduction of $15 \%$ by 2030 , taking 2010 as the base year.

Measures related to the energy sector

- None, but the INDC explicitly covers the energy sector.

Green industrial policies

- None.

Green government procurement

- None.

Financial and direct trade measures (subsidies, carbon pricing, taxation, R\&D etc.)

- None.

International cooperation (climate finance, technology transfer, international mechanisms etc.)

- Botswana will use market mechanisms under the UNFCCC. 


\section{GHG and non-GHG target}

- Brazil intends to commit to the reduction of greenhouse gas emissions by $37 \%$ below 2005 levels in 2025. Subsequent indicative contribution is a reduction of $43 \%$ below 2005 levels in 2030.

\section{Measures related to the energy sector}

- Increase in the share of sustainable biofuels in the Brazilian energy mix to approximately $18 \%$ by 2030, by expanding biofuel consumption, increasing ethanol supply, including by increasing the share of advanced biofuels (second generation), and increasing the share of biodiesel in the diesel mix.

- Expansion of the use of renewable energy sources other than hydropower in the total energy mix to between $28 \%$ and $33 \%$ by 2030 .

- Expansion of the use of non-fossil fuel energy sources, increasing the share of renewables in the power supply to at least $23 \%$ by 2030 including by raising the share of wind, biomass and solar.

- Achievement of $10 \%$ efficiency gains in the electricity sector by 2030 .

\section{Green industrial policies}

- New standards of clean technology; energy efficiency measures and low carbon infrastructure.

\section{Green government procurement}

- None.

Financial and direct trade measures (subsidies, carbon pricing, taxation, R\&D etc.)

- None.

\section{International cooperation (climate finance, technology transfer, international mechanisms etc.)}

- Brazil reserves its position in relation to the possible use of any market mechanisms that may be established under the Paris agreement.

- Any transfer of units resulting from mitigation outcomes achieved in the Brazilian territory will be subject to prior and formal consent by the Federal Government. Brazil will not recognize use of units acquired through any mechanism, instrument or arrangement established outside the UNFCCC, its Kyoto Protocol or its Paris Agreement.

- The implementation of Brazil's NDC is not contingent upon international support, yet it welcomes support from developed countries with a view to generate global benefits. Additional actions would demand large-scale increase of international support and investment flows, as well as technology development, deployment, diffusion and transfer.

- Brazil will undertake best efforts to enhance cooperation initiatives with other developing countries. 


\section{GHG and non-GHG target}

- Reduction in total energy consumption by $63 \%$ by 2035 compared to a BAU scenario; and increase in the share of renewables so that $10 \%$ of the total power generation is sourced from renewable energy by 2035.

- Reduction in carbon dioxide emissions from morning peak hour vehicle use by $40 \%$ by 2035 compared to a BAU scenario.

\section{Measures related to the energy sector}

- Utilisation of 10-15 MW potential of waste to energy resources that have already been identified.

- Increase in the use of solar power as a renewable resource, building on three year study which was carried out from 2010-2012 on six types of solar cells at the Tenaga Suria Solar Power Plant.

- Studies are being undertaken to identify measures to reduce flaring and venting during gas extraction.

- Other alternative energy sources such as wind power, hydropower and tidal power are currently being researched.

\section{Green industrial policies}

- Energy Efficiency and Conservation Building Guidelines for Non-Residential Sector.

- Standards and Energy Labelling for Products and Appliances.

- Fuel economy regulation.

\section{Green government procurement}

- None.

Financial and direct trade measures (subsidies, carbon pricing, taxation, R\&D etc.)

- Electricity tariff reform.

- Financial incentives such as tax exemptions, tax reductions or rebate schemes on energyefficient appliances and products.

\section{International cooperation (climate finance, technology transfer, international mechanisms etc.)}

- Brunei Darussalam will continue to collaborate with its partners at sub-regional, regional and international level to enhance its capability and capacity towards achieving its climate mitigation and adaption objectives. 


\section{GHG and non-GHG target}

- Three scenarios:

- Unconditional reduction og GHG emissions by $6.6 \%$ when compared to BAU, for ongoing investments of US $\$ 1.25$ billion.

- A Hybrid Conditional scenario (11.6\% reduction), for investments of US $\$ 756,032,667$.

- A third scenario, Adaptation, (36.95\% reduction), for an overall investment of US $\$ 5,804,949,915$.

\section{Measures related to the energy sector}

- Use of alternative energy sources (solar, biofuels etc.), with annexed list of unconditional and conditional projects relating to electricity production.

\section{Green industrial policies}

- None.

\section{Green government procurement}

- Promotion of architectural structures that use materials that are local, renewable and insulating and have a low energy cost for all public construction.

Financial and direct trade measures (subsidies, carbon pricing, taxation, R\&D etc.)

- Use of the Environmental Intervention Fund to receive and distribute the receipts from the sale of carbon resulting from mitigation.

- Promotion of renewable energy, at least by eliminating fossil fuel subsidies and, at best, by subsidising investments in renewable energy.

- Subsidies and tax breaks for private residences to promote sustainable architectural structures.

\section{International cooperation (climate finance, technology transfer / international mechanisms etc.)}

- The availability of financing sources will depend on the ability of Burkina Faso to develop active cooperation with financing partners and institutions. To finance adaptation and mitigation projects, Burkina Faso could rely on access to the Green Climate Fund (GCF). The strengthening of bilateral relations with friendly countries and multilateral relations with institutions such as the World Bank, the European Union, the GEF, the UNDP, the UNEP, the $A D B$, the IDB, the BOAD, the ECOWAS or WAEMU may permit Burkina Faso to finance these projects within the framework of climate change and international agreements and conventions.

- Burkina Faso also supports the use of market mechanisms such as the CDM. 


\section{GHG and non-GHG target}

- Unconditional reduction of greenhouse gas emissions by $3 \%$ compared to BAU scenario for 2030

- Conditional reduction of greenhouse gas emissions by $20 \%$, beginning in 2016 , compared to BAU scenario for 2030.

\section{Measures related to the energy sector}

- Burundi is in the process of building three hydroelectric power plants. This programme will increase the country's electrification rate to $35 \%$.

- Development of hydroelectricity (conditional).

- Decentralized rural electrification through the use of photovoltaic systems (conditional).

\section{Green industrial policies}

- Energy efficiency in production, transport, distribution and consumption (reduction of losses, low energy light bulbs and energy saving equipment).

\section{Green government procurement}

- None.

Financial and direct trade measures (subsidies, carbon pricing, taxation, R\&D etc.)

- Support to R\&D for development of small scale hydro-power (Pico hydro, water wheels, etc.), distribution and extension of renewable energies (biogas, wind power and gasification), urban waste recovery techniques, and urban transit with low GHG emissions.

International cooperation (climate finance, technology transfer, international mechanisms etc.)

- Promotion of technology transfer to support research and development, adopt new technologies, and harness them for the national context. 


\section{GHG and non-GHG target}

- Unconditional commitment to achieve $100 \%$ grid access by 2017 ; and $30 \%$ RE penetration rate into the electric grid by 2025. With international support, Cabo Verde seeks to increase the renewable energy uptake in electricity to $100 \%$ by 2025, with best efforts to achieve this goal already by 2020 .

- Unconditional long-term commitment to reduce overall energy demand by $10 \%$ in relation to the Base Scenario by 2030. With international support, Cabo Verde seeks to reduce overall energy demand by $20 \%$ in relation to the Base Scenario by 2030 , with best efforts to achieve this indicative reduction effort already by 2025.

\section{Measures related to the energy sector}

- Smart-grid enhancement for the country's 9 independent networks with state-of-the-art power conditioning, production and distribution control.

- Built-up of energy storage facilities (including through batteries and flywheels).

- Design of renewable micro-grids and individual energy systems (solar home systems), and systematic deployment of solar-water-heaters across all islands.

- Planning of at least 1 landfill equipped with gas-to-energy systems by 2025, and development of stand-alone bio-energy solutions.

- Creation of a network of energy services companies (ESCOs) and clean-energy business incubators.

- Use of PPPs and simplified procedures for licensing and certification to implement RE roadmap.

\section{Green industrial policies}

- Improvement of energy efficiency of large consumers, including through mandatory installation of solar-water-heater components.

- Implementation of a green building code, seeking to cover all new (public or private) buildings.

- Promoting of smaller distributed energy solutions for water pumping, distribution and irrigation.

- Creation of energy rating labels for domestic appliances and air conditioning.

\section{Green government procurement}

- NAMA to consider options for boosting hybrid and electric fleet in the country, in particular, the feasibility of making government vehicles electrically powered by 2030.

Financial and direct trade measures (subsidies, carbon pricing, taxation, R\&D etc.)

- To implement its renewable energy roadmap, Cabo Verde envisions the creation of robust competitive market conditions, and the consideration of specific fiscal incentives to attract the private sector.

\section{International cooperation (climate finance, technology transfer, international mechanisms etc.)}

- Several conditional measures envisaged may be financed through mechanisms and/or carbon markets, including the CDM, new market and non-market based mechanisms, and credited NAMAs. 
- The Government of Cabo Verde is dependent on international support in the form of technology support, capacity-building, business development, private-sector involvement, and international climate finance. 


\section{GHG and non-GHG target}

- Cambodia proposes a $27 \%$ reduction in emissions below BAU by 2030 , excluding LULUCF.

\section{Measures related to the energy sector}

- National grid connected renewable energy generation (solar energy, hydropower, biomass and biogas) and connection of decentralised renewable generation to the grid.

- Off-grid electricity such as solar home systems, hydro (pico, mini and micro).

\section{Green industrial policies}

- Promoting use of renewable energy and adopting energy efficiency for garment factory, rice mills, and brick kilns.

- Motor vehicle inspection and eco-driving, and the increased use of hybrid cars, electric vehicles and bicycles.

\section{Green government procurement}

- None.

Financial and direct trade measures (subsidies, carbon pricing, taxation, R\&D etc.)

- None.

International cooperation (climate finance, technology transfer, international mechanisms etc.)

- Cambodia requires support in the form of financing, capacity building, and technology transfer to implement the actions set out.

- The support received will be channelled through bilateral and multilateral mechanisms, including market based mechanisms, including the GCF and traditional development funds. 


\section{GHG and non-GHG target}

- Reduction of GHG emissions up to 32\% compared to a reference scenario for the target year (2035), and conditional support from the international community on financing, capacity building and transfer of technologies.

\section{Measures related to the energy sector}

- Implementation of the Rural Electrification Master Plan.

- Promotion of the development of "mini smart grids" in rural areas.

\section{Green industrial policies}

- Mandatory and regular audits in large energy-intensive industries.

- Promotion of energy audits in SMEs.

- Process optimization through more efficient technologies, efficiency, and phase-out.

- Evaluation of potential substitution or optimization (e.g. cogeneration or recovery)

- Limitation of losses (flares, networks, waste) by enforcing regulations and by standards, pricing and incentives.

- Revision of the building code to improve energy performance by standards of construction and renovation, and a certification process.

\section{Green government procurement}

- None.

Financial and direct trade measures (subsidies, carbon pricing, taxation, R\&D etc.)

- Economic incentives to promote and remove barriers to investment in energy efficiency.

- Incentives framework for renewable energy development (tendering, feed-in tariffs, etc.) and removal of barriers to investment (strengthening the institutional framework, etc.).

- Financial facilitations for rural lighting as through the Rural Electrification Fund (REF).

- Support for the scrapping of polluting vehicles via standards, incentives or obligations.

- Financial measures related to environmental goods and services

$\circ$ Financial incentives for the purchase of less polluting vehicles.

International cooperation (climate finance, technology transfer, international mechanisms etc.)

- Promotion of the integration and participation of Cameroon in the sub-regional energy market through interconnection with other countries from the subregion, including Energy Pool of Central Africa (PEAC) and West Africa through Nigeria (WAPP). 


\section{GHG and non-GHG target}

- Canada intends to achieve an economy-wide target to reduce our greenhouse gas emissions by $30 \%$ below 2005 levels by 2030 .

\section{Measures related to the energy sector}

- Canada will gradually phase down HFCs, which will limit potent GHG emissions that are expected to increase substantially in the next 10 to 15 years.

- Regulatory measures to reduce GHG emissions from natural gas-fired electricity, as well as from chemicals and nitrogen fertilizers.

- Regulatory measurs to reduce methane emissions from the oil and gas sector.

- Phase-out of existing coal-fired electricity units without carbon capture and storage.

\section{Green industrial policies}

- Establish more stringent standards in the transportation sector for heavy-duty vehicles of post2018 model years.

- Renewable fuels regulations to require that gasoline contain an average $5 \%$ renewable fuel content and that most diesel fuel contain an average $2 \%$ content.

\section{Green government procurement}

- None.

Financial and direct trade measures (subsidies, carbon pricing, taxation, R\&D etc.)

- Canada will focus climate-related investments in innovative production technologies to continue to drive further improvements in environmental performance in the oil sands and other growing sectors.

- Investments towards the development and demonstration of clean technology products such as electrical vehicle charging stations and wind hybrid power plants.

- Investments to encourage the generation of electricity from renewable energy sources such as wind, low-impact hydro, biomass, photovoltaic and geothermal energy.

\section{International cooperation (climate finance, technology transfer, international mechanisms etc.)}

- Cooperative action with continental trading partners, particularly the United States, and further action in integrated sectors of the economy. 


\section{GHG and non-GHG target}

- Reduction of emissions by $5 \%$ compared to the BAU reference level at the 2030 horizon and $25 \%$ at the 2050 horizon, within the framework of conditional implementation. The Central African Republic also aspires to reduce emissions of short-lived climate pollutants (SLCP).

\section{Measures related to the energy sector}

- Construction of a photovoltaic solar power plant at Bangui (conditional).

- Development of $180 \mathrm{MW}$ Dimoli hydroelectric plant, $72 \mathrm{MW}$ Lobaye hydroelectric plant, $60 \mathrm{KW}$ La Kotto hydroelectric plant, and Mobaye Electric plant (conditional).

- National Rural Electrification Programme (conditional).

- Construction of a sluice dam along the Ubangi at Zinga (conditional).

- Programme for the reduction of short-lived pollutants (conditional).

\section{Green industrial policies}

- National biofuels programme (conditional).

\section{Green government procurement}

- None.

Financial and direct trade measures (subsidies, carbon pricing, taxation, R\&D etc.)

- None.

International cooperation (climate finance, technology transfer, international mechanisms etc.)

- The Central African Republic supports the creation of international market instruments, such as the Clean Development Mechanism, and requires capacity building and technology transfer in priority areas. 


\section{GHG and non-GHG target}

- Unconditional reduction of $18.2 \%$ of GHG emissions compared to the reference scenario by 2030.

- Conditional reduction of $71 \%$ of GHG emissions by 2030.

\section{Measures related to the energy sector}

- Production of solar energy increased to $200 \mathrm{GWh} / \mathrm{year}$.

- Production of wind energy up to $50 \mathrm{GWh} /$ year

- Construction of a national $225 \mathrm{kv}$ line to interconnect all cities and cross-country power grid.

\section{Green industrial policies}

- None.

\section{Green government procurement}

- None.

Financial and direct trade measures (subsidies, carbon pricing, taxation, R\&D etc.)

- None.

\section{International cooperation (climate finance, technology transfer, international mechanisms etc.)}

- The Republic of Chad does not intend to appeal to the international carbon markets in order to compensate for its own emissions. The country hopes, by contrast, to encourage investment in mitigation projects on its own territory, notably by means of the CDM and the REDD+ programme.

- Implementation of mitigation actions is conditional on the availability of international support in terms of funding, technology transfer and reinforcement of capacity, including through agencies for development assistance, bilateral and multilateral financial institutions, GCF, GEF, and private sector.

- Interconnection of Chad-Cameroon power grids to supply Chad with hydro-generated energy of $500 \mathrm{GWh}$. 


\section{GHG and non-GHG target}

- Chile is committed to reduce its $\mathrm{CO} 2$ emissions per GDP unit by $30 \%$ below their 2007 levels by 2030 , assuming a future economic growth rate which allows to implement adequate measures.

- In addition, and subject to the grant of international monetary funds, the country is committed to reduce its $\mathrm{CO} 2$ emission per GDP unit by 2030 until it reaches a $35 \%$ to $45 \%$ reduction with respect to the 2007 levels.

\section{Measures related to the energy sector}

- $30 \%$ reduction in the marginal costs of electric energy by $2018.20 \%$ of the energetic matrix should be made up of non-conventional renewable energies by $2025.20 \%$ reduction in the energy consumption forecast by 2025.

\section{Green industrial policies}

- National Sustainable Construction Strategy to integrate concept of sustainable development in construction sector.

\section{Green government procurement}

- None.

Financial and direct trade measures (subsidies, carbon pricing, taxation, R\&D etc.)

- CO2 emission tax. Annual tax benefit lien on carbon dioxide, among other gases, produced by facilities whose stationary sources, made up of boilers or turbines, have an aggregate thermal power equal or higher than $50 \mathrm{MWt}$.

- Financial measures related to environmental goods and services

$\circ$ Tax on initial sale of lightweight vehicles, charging a tax which inversely proportional to vehicle performance.

International cooperation (climate finance, technology transfer, international mechanisms etc.)

- By 2018 Chile will have a technology development and transfer strategy.

- Creation of internal institutions which will allow to optimally manage and coordinate the relationship with the Green Climate Fund.

- Design of financial instruments which can be used for purposes such as adaptation and technology transfer. 


\section{GHG and non-GHG target}

- China commits to achieve the peaking of carbon dioxide emissions around 2030 and making best efforts to peak early; to lower carbon dioxide emissions per unit of GDP by $60 \%$ to $65 \%$ from the 2005 level; and to increase the share of non-fossil fuels in primary energy consumption to around $20 \%$.

\section{Measures related to the energy sector}

- Increase in share of concentrated and highly efficient electricity generation from coal.

- Reduction of coal consumption of electricity generation of newly built coal-fired power plants to around 300 grams of coal equivalent per kilowatt-hour.

- Expansion of use of natural gas: by 2020 , achieving more than $10 \%$ share of natural gas consumption in the primary energy consumption and making efforts to reach 30 billion cubic meters of coal-bed methane production.

- Development of hydropower, on the premise of ecological and environmental protection and inhabitant resettlement.

- Development of nuclear power in a safe and efficient manner; to develop geothermal energy, bio-energy and maritime energy; and scaling up of wind and solar power.

- Achievement of the installed capacity of wind power reaching 200 gigawatts, the installed capacity of solar power reaching around 100 gigawatts and the utilization of thermal energy reaching 50 million tons coal equivalent by 2020 .

- Enhancement of the recovery and utilization of vent gas and oilfield-associated gas.

- Scaling up of distributed energy and strengthen the construction of smart grids.

\section{Green industrial policies}

- Control of total coal consumption and enhancement of clean use of coal.

- Strict control of greenhouse gas emissions in Urbanized Zones for Optimized Development.

- Enhancement of carbon intensity control in Urbanized Zones for Focused Development and to accelerate green and low-carbon transformation in old industrial bases and resource-based cities.

- Introduction of a withdrawal mechanism for those industries that do not match with functions of development-planning zones and to develop low-carbon industries in line with local conditions and circumstances.

- China commits to embark on a new path of industrialization, developing a circular economy, optimizing the industrial structure, revising the guidance catalogue of the adjustment of industrial structure, strictly controlling the total expansion of industries with extensive energy consumption and emissions, accelerating the elimination of outdated production capacity and promoting the development of service industry and strategic emerging industries.

- Promotion of the share of value added from strategic emerging industries reaching $15 \%$ of the total GDP by 2020.

- Promotion of low-carbon development of industrial sectors, implementing Action Plan of Industries Addressing Climate Change (2012-2020) and formulating carbon emission control target and action plans in key industries.

- Research and formulation of greenhouse gas emission standards for key industries. 
- Effective control of emissions from key sectors including power, iron and steel, nonferrous metal, building materials and chemical industries through energy conservation and efficiency improvement.

- Management of carbon emissions for new projects and control of greenhouse gas emissions originating from the industrial production process.

- Construction of a recycling-based industrial system, promoting recycling restructure in industrial parks, increasing the recycling and utilization of renewable resources and improving the production rate of resource.

- Phase down in the production and consumption of HCFC-22 for controlled uses, with its production to be reduced by $35 \%$ from the 2010 level by 2020 , and by $67.5 \%$ by 2025 and to achieve effective control on emissions of HFC- 23 by 2020.

- Promotion of low-carbon development of service industry, actively developing low-carbon business, tourism and foodservice and vigorously promoting service industries to conserve energy and reduce carbon emissions.

- Establishment of a greenhouse gas emission reporting mechanism for key enterprises.

- Formulation of a greenhouse gas emission accounting standards for enterprises in key sectors.

- Research on and establishment of carbon emission accreditation and low-carbon honor system, to carry out low-carbon certification pilots and promotion of selected products.

- Improvement of the quality of gasoline and promotion of new types of alternative fuels.

\section{Green government procurement}

- Improvement in green government procurement policy systems including that on procurement of low-carbon and energy-conservation products.

\section{Financial and direct trade measures (subsidies, carbon pricing, taxation, R\&D etc.)}

- Innovation in the application of funds and new investment and financing mechanisms for lowcarbon development, such as public-private partnerships.

- Reform in the pricing and taxation regime for energy-and-resource-based products.

- Improvement of the green credit mechanisms, to encourage and guide financial institutions to operate energy-efficiency crediting business and to issue asset- securitized products for green credit assets.

- Building on carbon emission trading pilots, steady implementation a nationwide carbon emission trading system and gradual establishment of the carbon emission trading mechanism.

- Encouragement of the development and use of low-carbon and environment-friendly means of transport, such as new energy vehicle and vessel.

- Financial measures related to environmental goods and services

- Implementation of preferential taxation policies for promoting the development of new energy and to improve mechanisms of pricing, grid access and procurement mechanisms for solar, wind and hydro power.

- Research and development and commercialization demonstration for low-carbon technologies, such as energy conservation, renewable energy, advanced nuclear power technologies and carbon capture, utilization and storage and to promote the technologies of utilizing carbon dioxide to enhance oil recovery and coal-bed methane recovery.

- Development of technologies on biological nitrogen fixation, green pest and disease prevention and control and protected agriculture.

- R\&D on technologies for water saving and desalination of sea water. 
International cooperation (climate finance, technology transfer, international mechanisms etc.)

- Promotion of global green low-carbon transformation and innovation.

- International commitments that match China's national circumstances, current development stage and actual capabilities by enhancing mitigation and adaptation actions and further strengthening south-south cooperation on climate change.

- Establishment of the Fund for South-South Cooperation on Climate Change, providing assistance and support, within its means, to other developing countries including the small island developing countries, the least developed countries and African countries to address climate change. 


\section{GHG and non-GHG target}

- The Republic of Colombia commits to reduce its greenhouse gas emissions by $20 \%$ with respect to the projected BAU by 2030.

- Subject to the provision of international support, Colombia could increase its ambition from $20 \%$ reduction with respect to BAU to $30 \%$ with respect to BAU by 2030 .

\section{Measures related to the energy sector}

- None, but the INDC explicity covers the energy sector.

\section{Green industrial policies}

- Sectorial Mitigation Action Plans (SMAPs) that aim to maximize the carbon-efficiency of economic activities at the national and sectorial levels and in turn contribute to social and economic development.

\section{Green government procurement}

- None.

Financial and direct trade measures (subsidies, carbon pricing, taxation, R\&D etc.)

- Creation of climate change innovation clusters, through the promotion of private investment, public private partnerships and foreign direct investment, with special emphasis on the scientific research and the knowledge and technology transfer. Promotion of research, innovation, and technological development.

International cooperation (climate finance, technology transfer, international mechanisms etc.)

- Scaling up of Colombia's south-south and triangular cooperation on climate change, under the leadership of the organizations coordinating international cooperation in the country.

- Colombia will explore the use of market instruments (or other economic instruments) that guarantee the principles of transparency and environmental integrity, which result in real, permanent, additional, verified mitigation outcomes and prevent double counting. 


\section{GHG and non-GHG target}

- Comoros commits to reduce its GHG emissions in 2030 by $84 \%$ compared to the BAU scenario. This commitment could be achieved with the support of the international community to enable the Comoros to access additional sources of financing including through new mechanisms of climate finance, or the Green Climate Fund.

\section{Measures related to the energy sector}

- Reduction of losses on the electrical grid.

- Rehabilitation of power plants; adoption of solar; strengthening of hydro potential; geothermal, biogas.

- Promotion of the use of LPG instead of oil and wood.

\section{Green industrial policies}

- None.

\section{Green government procurement}

- None.

Financial and direct trade measures (subsidies, carbon pricing, taxation, R\&D etc.)

- None.

International cooperation (climate finance, technology transfer, international mechanisms etc.)

- All adaptation projects are funded by foreign aid. Comoros will need around USD 675 million to complete the implementation of its INDC, including USD 375 million for mitigation and \$ 300 million for adaptation.

- The need for capacity building include human capacity in various areas, institutional capacity, and financial frameworks, better planning in terms of policy, strategies and action plans; and monitoring.

- The technology needs for mitigation include technologies on renewable energy such as solar, hydro, wind and geothermal energy, energy efficiency in the building industry and others. 


\section{GHG and non-GHG target}

- The Republic of Congo commits to reducing at least $48 \%$ reduction in emissions compared to BAU scenario in 2025 and 55\% in 2035, in a conditional low-carbon scenario (depending on the support of the international community).

\section{Measures related to the energy sector}

- Plan for the solar electrification of remote villages and hydropower development.

- Emissions from gas flaring associated with oil production are the subject of several measures, in the context of Congo's participation in the initiative "Zero Flaring Routine 2030". The gas then used in two new gas plants, Djéno (50MW) and Maltève Coast (300MW).

\section{Green industrial policies}

- Increasing the share of renewable energy to be used for the extraction of mining products to $90 \%$ in 2025 and $95 \%$ in 2035 (use of biomass plantations in savannah in addition to hydropower).

- Industrial investments would be required to implement environmental and social ethics and they should meet the following conditions: (i) establishment of road, power and port infrastructures for "green" production and smooth flow of goods including export; (ii) involvement of the state and Congolese investors in the industrial, service or building sectors; (iii) cooperation of private investor and Congolese banks with investors and international donors to finance industrial investment.

\section{Green government procurement}

- None.

Financial and direct trade measures (subsidies, carbon pricing, taxation, R\&D etc.)

- None.

\section{International cooperation (climate finance, technology transfer, international mechanisms etc.)}

- The international community would be required to provide the amount of 5.14 billion euros for the period 2015-2025. 


\section{GHG and non-GHG target}

- The DRC is committed to reducing its emissions by $17 \%$ by 2030 compared to emissions from the BAU scenario (430 Mt CO2e), a reduction of just over $70 \mathrm{Mt} \mathrm{CO} 2 \mathrm{e}$ avoided (conditional).

Measures related to the energy sector

- Rural and urban hydroelectrification.

- Improvements in mining and oil exploitation.

\section{Green industrial policies}

- None.

\section{Green government procurement}

- None.

Financial and direct trade measures (subsidies, carbon pricing, taxation, R\&D etc.)

- None.

International cooperation (climate finance, technology transfer, international mechanisms etc.)

- The actions of the DRC will be conditional upon the provision of adequate support corresponding in terms of financial resources, technology transfer and capacity building. 


\section{GHG and non-GHG target}

- The Cook Islands is committed to a future powered by renewable energy with targets of $50 \%$ of islands transformed from diesel based to renewable sourced electricity by 2015 , to $100 \%$ coverage by 2020. GHG emission reduction under this scenario will be of $38 \%$ by 2020 on 2006 levels.

- $81 \%$ emissions reduction by 2030 on 2006 levels, conditional on external support.

\section{Measures related to the energy sector}

- Construction of additional and new grid storage.

\section{Green industrial policies}

- Improved energy efficiency and new technologies and technology transfer.

\section{Green government procurement}

- None.

Financial and direct trade measures (subsidies, carbon pricing, taxation, R\&D etc.)

- Customs Tariff Act 2012 established noteworthy duty rates on the importation of motor vehicles.

- Financial measures related to environmental goods and services

$\circ$ The Cook Islands is looking to embrace proven low carbon transport technologies and is currently exploring the most effective incentives for promotion of transition towards clean energy transportation.

International cooperation (climate finance, technology transfer, international mechanisms etc.)

- None. 


\section{GHG and non-GHG target}

- Aspiration of becoming a carbon neutral economy starting year 2021, as a culmination of Costa Rica's voluntary, pre-2020 action, with total net emissions comparable to total emissions in 2005.

- Costa Rica's commitment includes an emissions reduction of GHG of $44 \%$ compared to a BAU scenario, and a reduction of $25 \%$ of emission compared to 2012 emissions.

\section{Measures related to the energy sector}

- None, but the INDC explicity covers the energy sector.

\section{Green industrial policies}

- Work with the industrial sector on energy conservation and fuel switching in productive processes to reduce energy demand and decarbonize the energy supply.

\section{Green government procurement}

- Improvement of public transportation in terms of fleet composition as well as working design.

Financial and direct trade measures (subsidies, carbon pricing, taxation, R\&D etc.)

- Possibility of using a Domestic Compensation Market to accomplish INDC targets.

International cooperation (climate finance, technology transfer, international mechanisms etc.)

- Costa Rica reserves its sovereign right to use international compensation units to accomplish its goals within the National Contribution. 


\section{CÔTE D'IVOIRE (TRANSLATION)*}

\section{GHG and non-GHG target}

- Reduction of GHG emissions by $28 \%$ relative to emissions in the target year (2030) in a BAU scenario.

- A combination of $42 \%$ renewable energy in the electricity mix in 2030.

\section{Measures related to the energy sector}

- Development of: (i) small hydropower; (li) methane (waste, agricultural residues ...) PVs (solar PV kits, PV pumping system...); biomass (sustainable use of wood energy).

- Reduction of investment barriers (strengthening the institutional framework, investment security, training of banks...).

- Investment in energy efficiency and renewables, improving participation rates in the electricity $\operatorname{mix}$ in 2030.

\section{Green industrial policies}

- Reduction of waste in the energy consumption of industries (e.g. through diagnosis or energy audits; accounting to provide reliable and continuous data; consumption).

- Development of national regulations on the thermal efficiency of buildings.

- Encouragement of businesses to invest in more energy efficient equipment.

\section{Green government procurement}

- None.

\section{Financial and direct trade measures (subsidies, carbon pricing, taxation, R\&D etc.)}

- Investments in R\&D and capacity building for the Institute for Research on Renewable Energy (IREN).

- Disposal of pollutants via standards, incentives or obligations

- Financial Measures related to environmental goods and services

- Development of a framework of incentives for development of renewable energy (RFP, FIT, tax exemptions).

- Facilitation of the purchase of low-emission vehicles.

\section{International cooperation (climate finance, technology transfer, international mechanisms etc.)}

- Integration of the Ivory Coast in the regional market of energy, through interconnection with other countries in the region.

- Côte d'Ivoire will seek support from donors and TFP (grants, loans and technical assistance) for the financing of INDC actions. Access to sovereign loans of Development Finance Institutions (DFIs) will be crucial.

- Côte d'Ivoire is considering whether to establish an accredited national entity to the Green Climate Fund (GCF). It has already begun the process of preparing for the operationalization of the GCF nationally (Readiness Program).

- Côte d'Ivoire supports the inclusion of international carbon markets such as the Clean Development Mechanism (CDM) in the climate agreement and proposes that such an 
instrument, coupled with an appropriate accounting system (MRV), can be used to help finance certain investments in low-carbon infrastructure and climate resilience.

- Côte d'Ivoire considers that some carbon development options in the INDC or additional actions could be funded entirely or in part by the international transfer of carbon credits taking into account environmental integrity considerations and transparency. 


\section{GHG and non-GHG target}

- None. The amount of your contribution will depend on the fulfillment of international obligations under the Convention.

\section{Measures related to the energy sector}

- Construction of 19 bioelectric plants conncted to sugar mills with $755 \mathrm{MW}$ from sugarcane and forest biomass; 13 wind farms with $633 \mathrm{MW} ; 74700 \mathrm{MW}$ photovoltaic and small hydroelectric plants.

- Use of organic waste for biogas production.

\section{Green industrial policies}

- Installation of $200000 \mathrm{~m} 2$ of solar heaters in the residential and industrial sectors.

\section{Green government procurement}

- Installation of LED technology with the distribution of 13 million lamps in the residential sector and 250,000 lamps for street lighting.

Financial and direct trade measures (subsidies, carbon pricing, taxation, R\&D etc.)

- None.

International cooperation (climate finance, technology transfer, international mechanisms etc.)

- Cuba reaffirms its willingness to cooperate in the capacity building in tackling climate change, especially with small island states. 


\section{GHG and non-GHG target}

- The Republic of Djibouti has committed to reducing its GHG emissions by $40 \%$ by the year 2030 , compared to a BAU scenario.

- An additional US \$1.6 billion, conditional on new funding sources like the Green Climate Fund, along with international support, would enable the country to reduce its emissions by a further $20 \%$ by 2030.

\section{Measures related to the energy sector}

- Installation of $60 \mathrm{MW}$ onshore wind turbines in Goubet.

- Installation of three solar power plants in Petit Bara, Ali Sabieh and Goubet, with an estimated photovoltaic potential of $250 \mathrm{MW}$.

- Exploitation of geothermal energy, whose potential is estimated at $1200 \mathrm{MW}$ in the region around Lake Assal, Lake Abbé and North Goubet (partly financed by the World Bank).

- Potential for production plant for electricity using household waste, tidal turbines, and additional onshore wind turbines.

\section{Green industrial policies}

- None.

\section{Green government procurement}

- Improvement in the energy efficiency of the old Cité Ministérielle building and installation of a photovoltaic solar park on the roof of the building. The project will be extended all public buildings.

- Energy audit of all administrative buildings.

Financial and direct trade measures (subsidies, carbon pricing, taxation, R\&D etc.)

- Incentives for households to replace air conditioners and refrigerators.

- Elimination of the import of 10,000 old cars producing too much pollution.

International cooperation (climate finance, technology transfer, international mechanisms etc.)

- Construction of a very high voltage line with a $50 \mathrm{MW}$ capacity to import electricity from Ethiopia to Djibouti (partly financed by African Development Bank). Building on the first one, construction of two more very high voltage lines with a $250 \mathrm{MW}$ capacity.

- For all conditional measures, it is very likely that Djibouti will need to access international funding to cover a large proportion of that investment. 


\section{GHG and non-GHG target}

- Dominica commits to progressively reduce total gross GHG emissions below 2014 levels at the following reduction rates: $17.9 \%$ by $2020 ; 39.2 \%$ by 2025 ; and $44.7 \%$ by 2030 .

\section{Measures related to the energy sector}

- Development with concessionary climate change financing provided under the Green Climate Fund or Clean Technology Fund, of a geothermal generation plant.

- Off-Grid Hybrid Micro-Hydro, Wind, Solar PV, and Diesel Generation Back-up for Ross University.

- Off-Grid Hybrid Wind, Solar, Biodiesel Generator Back-up in Off-grid Mini-Grid Configuration for South-East and East Coast of Dominica (three separate projects).

\section{Green industrial policies}

- Energy efficiency programme, with uptake to be enhanced by market-based mechanisms, and Green Building Code.

- Solar Photovoltaic (PV) conversion program for Commercial, Institutional and Manufacturing Facilities.

\section{Green government procurement}

- All government vehicles, at their time of replacement, will be replaced by hybrid vehicles.

Financial and direct trade measures (subsidies, carbon pricing, taxation, R\&D etc.)

- Dominica intends to introduce market-based mechanisms to promote energy conservation/efficiency.

- Sustainable Energy programs for private residences, including solar PV and solar thermal, using innovative financing mechanisms to offset capital costs for home owners.

- Financial measures related to environmental goods and services:

$\circ$ Dominica intends to reduce greenhouse gas emissions from the transport sector principally through incentives to promote the import of hybrid vehicles, on top of existing import duties, charges, and environmental taxes.

- Installation of solar PV panels and related equipment on the roofs (and in some cases, the grounds) of buildings in the hotel sector.

International cooperation (climate finance, technology transfer, international mechanisms etc.)

- Dominica's contribution is conditional upon receiving timely access to international climate change financing, technology development and transfer, and capacity building support for priority adaptation and mitigation measures. 


\section{GHG and non-GHG target}

- Dominican Republic commits to the reduction of $25 \%$ of base year emissions by 2030 (conditional upon favorable and predictable support, feasible climate finance mechanisms, and corrections to the failures of existing market mechanisms).

Measures related to the energy sector

- None, but the INDC explicitly covers the energy sector.

\section{Green industrial policies}

- None, but the INDC explicitly covers the industrial processes sector.

\section{Green government procurement}

- None.

Financial and direct trade measures (subsidies, carbon pricing, taxation, R\&D etc.)

- None.

International cooperation (preferential access, technology transfer, international mechanisms etc.)

- None. 


\section{GHG and non-GHG target}

- Ecuador intends to reduce its emissions in the energy sector in 20.4-25\% below the BAU scenario. A conditional level between $37.5 \%$ and $45.8 \%$ with respect to the BAU baseline has also been calculated. This is a second scenario dependent upon international support and will translate into a per capita emissions reduction in 2025 of $40 \%$ below the BAU levels.

- Ecuador aims to reach a 90\% of clean energy coming from hydroelectric plants in its total electricity production in 2017 and raise the proportion of renewable energy in the energy matrix even more until 2025.

\section{Measures related to the energy sector}

- Optimization of use of the gas associated to oil exploitation for electricity generation.

- Introduction of an installed capacity of electric generation from hydroelectric plants of 2,828 MW additional to the BAU in the first scenario and an extra 4,382 MW.

- Eolic proyects in San Cristobal and Villonaco.

- The Trans-amazon Electric Train.

\section{Green industrial policies}

- None.

\section{Green government procurement}

- None.

Financial and direct trade measures (subsidies, carbon pricing, taxation, R\&D etc.)

- None.

\section{International cooperation (climate finance, technology transfer, international mechanisms etc.)}

- The potential for additional reductions in GHG emissions could be harnessed in light of the appropriate circumstances in terms of availability of resources and support offered by the international community. 


\section{GHG and non-GHG target}

- None.

\section{Measures related to the energy sector}

- Widespread diffusion of locally-appropriate low-carbon energy production technologies, with substantial reductions in energy intensity.

- Construction of advanced generations of nuclear reactors to fill the gap between reducing fossil fuel dependence and the deployment of renewable energy.

- Replacement or upgrading of obsolete infrastructure.

\section{Green industrial policies}

- Promotion of energy efficiency to decouple demand on energy and economic growth.

\section{Green government procurement}

- None.

Financial and direct trade measures (subsidies, carbon pricing, taxation, R\&D etc.)

- A national market for carbon trading may be established. This national market may further be developed into a regional market.

- Reform of energy subsidies. This policy is implemented using four pillars, namely: set different prices for petroleum products based on energy generation efficiency; increase the efficiency of energy use; provide support to certain sectors to promote switching from conventional energy sources to clean energy sources; and apply the fuel subsidy smartcard system to ensure that subsidies are received by target beneficiaries.

\section{International cooperation (climate finance, technology transfer, international mechanisms etc.)}

- Locally-appropriate technology transfer and financial flows from industrialized countries to support carbon emission abatement according to the UNFCCC principles will be needed. 


\section{GHG and non-GHG target}

- None. Some quantitative targets of 2025 and 2030 will be duly agreed, quantified and presented before COP 22 and COP23.

\section{Measures related to the energy sector}

- Before COP 22, the power generation sector will define and commit to a goal of increasing renewable energy by 2025 . The goal should be of no less than $12 \%$ relative to the total electricity generated in the country in 2014; and define and reach a target of reducing GHG emissions by 2025.

\section{Green industrial policies}

- Rules to improve the quality of diesel fuel utilised in the country, to be implemented from 2018.

- Proposal to improve and maintain a quality private vehicle fleet, and public and freight transport, with defined targets for 2025.

\section{Green government procurement}

- None.

\section{Financial and direct trade measures (subsidies, carbon pricing, taxation, R\&D etc.)}

- Incentives and community systems to reduce the high cost of eco-efficiency, especially in lowincome socioeconomic classes, and improve thermal comfort in homes and offices (bioclimatic architecture, energy efficiency, microclimate, heat islands).

\section{International cooperation (climate finance, technology transfer, international mechanisms etc.)}

- International financial resources available to support El Salvador's commitments, which must be new and additional to official development assistance. These must ensure not only the strengthening of national capacities but also adequate access to technologies, among other types of cooperation.

- El Salvador requires effective access to financing mechanisms such as the Green Climate Fund (GCF) and technological mechanisms such as the Centre and Climate Technology Network (NCSC). 


\section{GHG and non-GHG target}

- Equatorial Guinea's ambition is to reduce emissions by $20 \%$ by 2030 , relative to 2010 levels; in order to achieve a $50 \%$ reduction by 2050 . That, conditional on support that is favorable and predictable, on climate finance mechanisms that are viable, and on distortions of existing market mechanisms being corrected.

\section{Measures related to the energy sector}

- Development of the hydroelectric potential of the river Wele, for the electrification of the entire Continental Region of the country.

- Reform and conditioning of hydroelectric centers Musola (0.4-0.5 MW) and Riaba (3.8 MW), for the electrification of the whole island of Bioko; and Bikomo in the continental region (3.2 MW).

- Support for wind, solar and / or tidal energy for remote islands of the country (Annobon, Corisco and others).

\section{Green industrial policies}

- Promotion of an industrial policy based on the use of new technologies.

- Adoption of guidelines on types of machinery and setting of limits on emissions.

- Adoption of directives on methods of operation optimal production.

\section{Green government procurement}

- Acquisition of modern aircrafts.

Financial and direct trade measures (subsidies, carbon pricing, taxation, R\&D etc.)

- None.

International cooperation (climate finance, technology transfer, international mechanisms etc.)

- None. 


\section{ERITREA}

\section{GHG and non-GHG target}

- Two scenarios: Eritrea commits to reducing by $39.2 \%$ unconditionally and $80.6 \%$ in the conditional scenario assuming external assistance compared to BAU scenarios by 2030.

- Eritrea intends to raise the share of electricity generation from renewable energy to $70 \%$ of the total electricity generation mix (wind, solar and geothermal) by 2030 . Moreover it intends to reduce transmission and distribution losses at least by $50 \%$.

\section{Measures related to the energy sector}

- Development of geothermal power, onshore wind turbines, solar PVs, efficient electric grids.

- Waste heat recovery project at cement plant.

\section{Green industrial policies}

- Restriction on import of used cars.

- Promotion of cogeneration in industry.

\section{Green government procurement}

- None.

Financial and direct trade measures (subsidies, carbon pricing, taxation, R\&D etc.)

- None.

\section{International cooperation (climate finance, technology transfer, international mechanisms etc.)}

- Eritrea requires international support for the development of its own technologies as well as for technology transfer and innovation to increase its adaptive capacity.

- Investment needs for Eritrea's conditional mitigation measures are estimated to be around USD 694 million. 


\section{GHG and non-GHG target}

- Ethiopia intends to limit its net GHG emissions in 2030 to $145 \mathrm{Mt}$ CO2e or lower. This would constitute a $255 \mathrm{MtCO}$ e reduction from the projected BAU emissions in 2030 or a $64 \%$ reduction from the BAU scenario in 2030.

- In the long term, Ethiopia intends to achieve its vision of becoming carbon-neutral, with the midterm goal of attaining middle-income status.

\section{Measures related to the energy sector}

- Expansion of electric power generation from renewable energy, particularly geothermal, wind and solar to minimize the adverse effects of droughts on predominantly hydroelectric energy sector.

\section{Green industrial policies}

- Introduction of modern and energy efficient technologies in transport, industry and building sectors.

\section{Green government procurement}

- None.

Financial and direct trade measures (subsidies, carbon pricing, taxation, R\&D etc.)

- Removal of fossil fuel subsidies (already implemented).

- Investment in improved transportation systems (e.g. railway) that utilize clean and renewable energy and investments in urban planning transition.

\section{International cooperation (climate finance, technology transfer, international mechanisms etc.)}

- Ethiopia intends to sell carbon credits during the period to contribute towards achieving its Green Economy Strategy. Ethiopia supports the development of effective accounting rules under the UNFCCC to guarantee the environmental integrity of market mechanisms.

- Full implementation of Ethiopia's INDC requires predictable, sustainable and reliable support in the form of finance, capacity building and technology transfer. Future research will determine the quantity and share of supported (i.e. conditional) versus unsupported contributions. 


\section{GHG and non-GHG target}

- The EU and its Member States are committed to a binding target of an at least $40 \%$ domestic reduction in greenhouse gas emissions by 2030 compared to 1990, to be fulfilled jointly.

\section{Measures related to the energy sector}

- None, but the NDC explicitly covers the energy sector.

\section{Green industrial policies}

- None, but the NDC explicitly covers industrial processes and product use.

\section{Green government procurement}

- None.

Financial and direct trade measures (subsidies, carbon pricing, taxation, R\&D etc.)

- None.

International cooperation (climate finance, technology transfer, international mechanisms etc.)

- No contribution envisaged from international credits.

- Legislative proposals to implement the 2030 climate and energy framework, both in the emissions trading sector and in the non-traded sector, to be submitted by the European Commission to the Council and European Parliament in 2015-2016 on the basis of the general political directions by the European Council. 


\section{GHG and non-GHG target}

- Fiji's target is for the renewable energy share in electricity generation to approach $100 \%$ by 2030 from around $60 \%$ in 2013. In addition an indicative reduction of 10\% CO2 emissions for energy efficiency improvements economy wide will be sought. In total, Fiji envisages a 30\% GHG emissions reduction over BAU for 2030.

\section{Measures related to the energy sector}

- Investment into more renewable energy projects which are feasible in Fiji such as solar (stand alone, solar farm, photovoltaic grid connected), biofuel, wind, micro hydro projects and biogas power generation (agricultural wastes).

\section{Green industrial policies}

- Promote and improve guidelines and technical standards for renewable energy technologies.

- Use of renewable energy could be considered a part of the approval process for new investments.

\section{Green government procurement}

- None.

Financial and direct trade measures (subsidies, carbon pricing, taxation, R\&D etc.)

- Continued research and development for energy from possible hydro carbon resources and hydrogen fuel cells.

- Continued research and development in the area of new renewable energy technology, including further exploration of ocean energy, geothermal energy, wave energy and generation of energy from waste.

\section{International cooperation (climate finance, technology transfer, international mechanisms etc.)}

- From the $30 \%$ emission reduction target, $10 \%$ will be achieved through the implementation of the Green Growth Framework, utilizing resources available in country (unconditional) whereas the remaining target can only be met with the availability of external funding amounting to US $\$ 500$ million (conditional).

- Fiji requires a combination of robust global market based mechanisms and direct aid transfers.

- Fiji's conditional goal will require substantial funding including fully functional bilateral, regional and international market mechanisms such as the CDM. 


\section{GHG and non-GHG target}

- Gabonese republic commits to at least a $50 \%$ reduction of GHG emissions compared to BAU.

\section{Measures related to the energy sector}

- Solar Electrification Plan for isolated villages.

- Hydropower development, with the aim of ensuring a 2025 supply of electricity of $80 \%$ based on hydropower and $20 \%$ on gas.

- Participation in the initiative on "Global Gas Flaring Reduction" (GGFR) by the World Bank, enactment in 2014 of Law No. 011/2014 banning flaring, participation in the initiative "Zero flaring Routine 2030". Gabon recognizes a right of exploitation in the areas of operations to operators who invest in compression units. This is equivalent to a refund of all the costs to operators.

\section{Green industrial policies}

- Ban on the imports of vehicles older than 3 years.

\section{Green government procurement}

- None.

Financial and direct trade measures (subsidies, carbon pricing, taxation, R\&D etc.)

- Establishment of a National Fund for Sustainable Development. The creation of this fund is under review. It will act in line with the National Climate Funds that are being developed in various countries.

- Domestic market: the Act to Guide Sustainable Development in Gabon establishes a virtuous mechanism by which all activities should carry out an assessment of their impact beforehand (Sustainability Impact Assessment), prepare a Management Plan to to control, reduce, and offset the negative effects.

\section{International cooperation (climate finance, technology transfer, international mechanisms etc.)}

- Purchase of carbon credits will not be utilised by Gabon.

- Gabon supports its own choices and research in parallel to the establishment of partnerships in accordance with the strategy presented in the INDC. The various fields of action in terms of financing for emission reduction are particularly the following: renewable energy projects (hydro in particular), treatment of wastewater and energy efficiency, technology transfer, and land use, both in land use planning and in agricultural and forestry projects. 


\section{GHG and non-GHG target}

- Excluding LULUCF and for Low Emissions Scenario, Gambia will reduce its overall emissions by about $44.4 \%$ in 2025 and $45.4 \%$ in 2030 .

\section{Measures related to the energy sector}

- Refurbishment and upgrading of the national grid (from $33 \mathrm{Kv}$ to $132 \mathrm{Kv}$ ) to reduce losses.

- Installation of solar PV, wind power and hydro-electric power plants.

\section{Green industrial policies}

- None.

\section{Green government procurement}

- None.

Financial and direct trade measures (subsidies, carbon pricing, taxation, R\&D etc.)

- None.

International cooperation (climate finance, technology transfer, international mechanisms etc.)

- None. 


\section{GEORGIA}

\section{GHG and non-GHG target}

- Georgia plans to unconditionally reduce its GHG emissions by $15 \%$ below the BAU scenario for the year 2030. This is equal to reduction in emission intensity per unit of GDP by approximately $34 \%$ from 2013 to 2030.

- The $15 \%$ reduction target will be increased up to $25 \%$ in a conditional manner. This is equal to reduction of emission intensity per unit of GDP by approximately 43\% from 2013 to 2030.

\section{Measures related to the energy sector}

- None, but the INDC explicitly covers the energy sector.

\section{Green industrial policies}

- None, but the INDC explicitly covers the industrial processes sector.

\section{Green government procurement}

- None.

Financial and direct trade measures (subsidies, carbon pricing, taxation, R\&D etc.)

- None.

International cooperation (climate finance, technology transfer, international mechanisms etc.)

- None. 


\section{GHG and non-GHG target}

- Ghana's emission reduction goal is to unconditionally lower its GHG emissions by $15 \%$ relative to BAU scenario of $73.95 \mathrm{MtCO}$ e by 2030 . An additional $30 \%$ emission reduction is attainable on condition that external support is made available to Ghana to cover the full cost of implementing the mitigation action (finance, technology transfer, capacity building). With this external support, a total emission reduction of $45 \%$ below the BUA emission levels can be achieved by 2030 .

\section{Measures related to the energy sector}

- Scaling up renewable energy penetration by $10 \%$ by 2030 .

- Double energy efficiency improvement to $20 \%$ in power plants.

- Exploring opportunities using clean coal technology in public electricity generation mix to meet its energy security objectives.

\section{Green industrial policies}

- Double energy efficiency improvement to $20 \%$ in industrial facilities.

- Green Cooling Africa Initiative.

- Expanding the adoption of market based cleaner cooking solutions.

- Abatement of fluorinated-gases (HFC-22 and HFC-410) from stationery air- conditioners.

\section{Green government procurement}

- None.

Financial and direct trade measures (subsidies, carbon pricing, taxation, R\&D etc.)

- Designing renewable energy purchase obligation (conditional).

- Phasing out fossil fuel subsidies (conditional).

- Establishing of national renewable energy fund (conditional).

- Set up feed-in-tariff for renewable energy technologies (conditional).

\section{International cooperation (climate finance, technology transfer, international mechanisms etc.)}

- In 10 years, Ghana intends to mobilize nearly USD 22.6 billion investment from both domestic and international public and private sources. USD 6.3 billion domestically $(28.3 \%$ of total investment) will be mobilized nationally whereas the USD 16 billion will come from international support.

- Ghana will be looking for international partnerships to take advantage of the opportunities for technology development and transfer and continuous up-skilling especially in the priority INDC sectors. 


\section{GHG and non-GHG target}

- Grenada commits to reducing its GHG emissions by $30 \%$ from the base year 2010 by 2025 , with an indicative reduction of $40 \%$ from the base year 2010 by 2030 .

\section{Measures related to the energy sector}

- Creating an appropriate, enabling and dynamic incentive regime, both regulatory and institutional, to achieve a more diversified and sustainable energy sector.

- Introduction of biofuel blends (specifically liquefied natural gas and diesel blend).

\section{Green industrial policies}

- None.

\section{Green government procurement}

- Installation of more energy efficient light bulbs in some government buildings.

\section{Financial and direct trade measures (subsidies, carbon pricing, taxation, R\&D etc.)}

- Implementation of gasoline and diesel taxes and implementation of fuel efficiency standards for vehicles through incentives.

- Financial measures related to environmental goods and services

- Tax reduction incentive for use of solar panels and solar water heaters.

International cooperation (climate finance, technology transfer, international mechanisms etc.)

- Grenada's INDC will cost USD $\$ 161,430,500.00$ to implement through 2025. Grenada anticipates meeting these costs through access to multilateral and bilateral support including through the Green Climate Fund, multilateral agencies and bilateral arrangements with development partners. These funds will be used to leverage the limited national resources and technical capacities that are available for combatting climate change.

- Grenada currently uses no market mechanisms but is willing to explore the potential of market mechanisms and other mechanisms under the UNFCC process that demonstrate environmental integrity. 


\section{GHG and non-GHG target}

- Guatemala plans to achieve a reduction of $11.2 \%$ of its total GHG emissions from the base year 2005 projected to 2030 (unconditional). Guatemala seeks a more ambitious reduction up to $22.6 \%$ of total GHG emissions from the base year 2005 projected to 2030 (conditional). As a condition to achieve this ambitious goal, it will require technical and financial support from public and private, new and additional international resources.

\section{Measures related to the energy sector}

- Increased use of renewable sources by $2030,80 \%$ of electricity generation will be from renewable sources.

- Security of electricity supply at competitive prices.

- Technical standard for connection, operation, control and commercialization of renewable generation.

\section{Green industrial policies}

- Development and coordination for private sector involvement through actions under the Cleaner Production Policy, which is implemented as a tool of competitiveness and environmental management.

\section{Green government procurement}

- None.

Financial and direct trade measures (subsidies, carbon pricing, taxation, R\&D etc.)

- Law establishing incentives for the development of renewable energy projects.

- Existence of an incentive program that encourages voluntary reduction activities or absorption of GHG emissions.

- Establishment of a program of tax incentives and subsidies focused on the use of clean energy for public and private transport, including legislation to regulate GHG emissions in the collective and individual public transport.

\section{International cooperation (climate finance, technology transfer, international mechanisms etc.)}

- Guatemala considers the potential participation in the carbon market mechanisms.

- The domestic resources are not enough to achieve the INDC commitments INDC. The country calls upon the international community to comply with a common but differentiated responsibility and to provide Guatemala with additional financial resources. 


\section{GHG and non-GHG target}

- The Republic of Guinea is planning to implement mitigation measures which will mean a deviation of around $-13 \%$ from the BAU scenario by 2030 , not counting its storage capacity through land use and forestry (excluding LUCF).

\section{Measures related to the energy sector}

- Hydropower stations producing $1650 \mathrm{MW}$ (127MW in 2011).

- Installing an additional 47MW (3MW in 2011) of solar and wind power.

- Increasing the supply of biofuels and other modern energies (40k toe of butane and biogas, $3000 \mathrm{kWc}$ of biofuels).

\section{Green industrial policies}

- None.

\section{Green government procurement}

- None.

Financial and direct trade measures (subsidies, carbon pricing, taxation, R\&D etc.)

- None.

International cooperation (climate finance, technology transfer, international mechanisms etc.)

- The investment needed to meet the targets in Guinea is calculated at US $\$ 8179$ million in current value over 20 years (2011-2030). This equates to around US\$409 million annual investment over 20 years, including activities ongoing since 2011.

- At present, government of Guinea has actually raised only $20 \%$ of the funds for this investment plan. The funding needs for the rollout of renewable energies and energy efficiency alone are therefore calculated at more than US $\$ 6.5$ billion. 


\section{GHG and non-GHG target}

- Guinea-Bissau is a net GHG sink country, but it is nevertheless willing to make efforts to further reduce their emissions depending on the financial, technological and capacity building support that it may receive from the international community.

\section{Measures related to the energy sector}

- $80 \%$ renewable energy in the national energy mix by 2030 .

- Energy efficiency - reduce energy losses up to $10 \%$ in the 2030.

- Electric power generation systems from renewable energies (hydro, photovoltaic systems, wind systems).

\section{Green industrial policies}

- None.

\section{Green government procurement}

- None.

Financial and direct trade measures (subsidies, carbon pricing, taxation, R\&D etc.)

- None.

International cooperation (climate finance, technology transfer, international mechanisms etc.)

- None. 
GHG and non-GHG target:

- Guyana's overarching contribution goal is to achieve a Green Economy via a low- emission economicdevelopment pathway. The contribution of Guyana and other developing countries will in the main be policy-based including measures to reduce the normative BAU growth in emissions. The time frame associated with Guyana's INDC is for the period up to 2025.

\section{Measures related to the energy sector}

- Guyana is in the process of reviewing options toward the rapid expansion of a renewable energy supply. Develop a mix of wind, solar, biomass and hydropower to supply both the demand of the national grid and the energy requirements for towns and villages in Guyana's hinterland.

- Guyana will seek to construct and/or promote the construction of small hydro systems at suitable locations such as Moco Moco, Kato and Tumatumari. Guyana will power all of the six newly established townships, starting with Bartica, using renewable energy sources. Currently, Guyana has installed cogeneration from bagasse to power sugar mills.

- Preliminary approvals have been given for a 26MW wind farm.

\section{Green industrial policies}

- None.

\section{Green government procurement}

- None.

Financial and direct trade measures (subsidies, carbon pricing, taxation, R\&D etc.)

- Financial measures related to environmental goods and services

- Legislation has been enacted to remove import duty and tax barriers for the importation of renewable energy equipment, compact fluorescent lamps and LED lamps to incentivize and motivate energy efficient behavior.

- Independent power producers and suppliers are being encouraged to construct energy farms and sell energy to the national grid.

\section{International cooperation (climate finance, technology transfer, international mechanisms etc.)}

- In order to implement its conditional adaptation actions, including infrastructural development works, Guyana will require an estimated US\$1.6 Billion in the period to 2025. 


\section{HAÏTI, REPUBLIC OF (TRANSLATION)*}

\section{GHG and non-GHG target:}

- The Republic of Haiti commits to reducing emissions by $31 \%$ compared with the trend development scenario, representing absolute Eq- $45.24 \mathrm{Mt}$ CO2. This effort is distributed as follows:

- Unconditional Objective: Reduce emissions by 5\% compared to the reference scenario (2000) to 2030, a cumulative $10 \mathrm{Mt} \mathrm{CO2-eq.}$

- Conditional Objective: Reduction of $26 \%$ additional emissions scenario development trend compared to 2030, a cumulative 35.24 Mt CO2-eq.

\section{Measures related to the energy sector}

- Installation of a 37.5 MW additional hydro in 2020 (unconditional).

- Increasing to $47 \%$ the share of renewable energy in the Haitian electric system by 2030 (24.5\% hydro, wind $9.4 \%, 7.5 \%$ solar, biomass $5.6 \%$ ).

- Install 2030 (4 Aeolian Parks: 50 MW Hydropower: additional 60MW Solar Parks: 30 MW Biomass: $20 \mathrm{MW}$ ).

- Improving energy efficiency furnaces production of charcoal (getting yields of $10-15 \%$ to 30 $45 \%)$.

\section{Green industrial policies}

- None.

\section{Green government procurement}

- None.

Financial and direct trade measures (subsidies, carbon pricing, taxation, R\&D etc.)

- Control and regulation of the importation of used vehicles (unconditional).

- Financial measures related to environmental goods and services

o Promote the use of energy efficient stoves to replace the traditional ones (energy saving of $25-30 \%$ per stove).

\section{International cooperation (climate finance, technology transfer, international mechanisms etc.)}

- The overall financial cost for the implementation of the commitments is estimated at 25.387 billion USD, 16.614 billion for adaptation actions and 8.773 billion for mitigation actions. Conditional and unconditional mitigation measures represent the amounts of USD 7.999 billion and USD 773,519,000. 
GHG and non-GHG target:

- The Republic of Honduras is committed to reducing $15 \%$ of its emissions compared to BAU scenario by 2030 for all sectors contained in this BAU scenario. This commitment is conditional on international support and climate financing mechanisms.

Measures related to the energy sector

- None, but the NDC explicitly covers the energy sector.

Green industrial policies

- None, but the NDC explicitly covers the industrial processes sector.

Green government procurement

- None.

Financial and direct trade measures (subsidies, carbon pricing, taxation, R\&D etc.)

- None.

International cooperation (climate finance, technology transfer, international mechanisms etc.)

- None. 


\section{GHG and non-GHG target:}

- Iceland aims to be part of a collective delivery by European countries to reach a target of $40 \%$ reduction of greenhouse gas emissions by 2030 compared to 1990 levels. A precise commitment for Iceland within such collective delivery has yet to be determined, and is dependent on an agreement with the European Union and its Member States and possibly other countries.

\section{Measures related to the energy sector}

- None, but the INDC explicitly covers the energy sector.

\section{Green industrial policies}

- None, but the INDC explicitly covers industrial processes and product use sector.

\section{Green government procurement}

- None.

Financial and direct trade measures (subsidies, carbon pricing, taxation, R\&D etc.)

- None.

\section{International cooperation (climate finance, technology transfer, international mechanisms etc.)}

- Iceland's participation in a common European market in emissions credits under the EU-ETS complicates the determination of a simple economy-wide target for Iceland, as credits under the EU-ETS are traded freely in a common market, with limited influence by Icelandic authorities. 
GHG and non-GHG target:

- India declared a voluntary goal of reducing the emissions intensity of its GDP by 20-25\%, over 2005 levels, by 2020 .

Measures related to the energy sector

- India is promoting greater use of renewables in the energy mix mainly through solar and wind power and shifting towards supercritical technologies for coal based power plants.

- Wind energy has been the predominant contributor to the renewable energy growth in India accounting for $23.76 \mathrm{GW}(65.2 \%)$ of the renewable installed capacity, the aim is to achieve a target of $60 \mathrm{GW}$ of wind power installed capacity by 2022.

- The National Electricity Policy (NEP) underscores the focus on universalizing access to electricity and promoting renewable sources of energy, as does the Integrated Energy Policy (IEP).

- Special programmes to promote small and mini hydro projects, new and efficient designs of water mills have been introduced for electrification of remote villages. With a vast potential of more than $100 \mathrm{GW}$, a number of policy initiatives and actions are being undertaken to aggressively pursue development of country's vast hydro potential.

- Biomass Energy: A number of programmes have been initiated for promotion of cleaner and more efficient use, including biomass based electricity generation. It is envisaged to increase biomass installed capacity to $10 \mathrm{GW}$ by 2022 from current capacity of $4.4 \mathrm{GW}$.

- India is promoting Nuclear Power to meet the increasing electricity needs of the country.

- Clean Coal Policies: About 144 old thermal stations have been assigned mandatory targets for improving energy efficiency. Coal beneficiation has been made mandatory. Introduction of ultra-supercritical technology. Stringent emission standards are being contemplated for thermal plants.

\section{Green industrial policies}

- Efforts are being made to efficiently use energy through various innovative policy measures under the overall ambit of Energy Conservation Act.

- India has a definite plan of action for clean energy, energy efficiency in various sectors of industries, steps to achieve lower emission intensity in the automobile and transport sector, a major thrust to non-fossil based electricity generation and a building sector based on energy conservation.

- Zero Effect, Zero Defect (ZED): The Make in India campaign with ZED is a policy initiative to rate Medium \& Small Industries on quality control and certification for energy efficiency, enhanced resources efficiency, pollution control, use of renewable energy, waste management.

- Standards and Labeling Programme to provide consumers with information about the energy consumption of an appliance. A Super-Efficient Fan programme has been launched. Further, two sets of Corporate Average Fuel Consumption standards for cars have been notified, with one coming into force in 2017 and the second set in 2022.

\section{Green government procurement}

- None 
Financial and direct trade measures (subsidies, carbon pricing, taxation, R\&D etc.)

- Fiscal instruments like coal cess, cuts in subsidies, increase in taxes on petrol and diesel, market mechanisms including Perform Achieve and Trade (PAT), Renewable Energy Certificates (REC) and a regulatory regime of Renewable Purchase Obligation (RPO).

- India has cut subsidies and increased taxes on fossil fuels (petrol and diesel) turning a carbon subsidy regime into one of carbon taxation. Further, in its effort to rationalize and target subsidies, India has launched 'Direct Benefit Transfer Scheme' for cooking gas, where subsidy will be transferred directly into the bank accounts of the targeted beneficiaries. Over the past one year India has almost cut its petroleum subsidy by about $26 \%$.

- Recent actions have led to an implicit carbon tax (USD 140 for petrol and USD 64 for diesel) in absolute terms. Estimates suggest that these measures will help India achieve a net reduction of 11 million tonnes of $\mathrm{CO} 2$ emissions in less than a year.

- National Smart Grid Mission has been launched to bring efficiency in power supply network and facilitate reduction in losses and outages. Green Energy Corridor projects worth INR (Indian National Rupee) 380 billion (USD 6 billion) are also being rolled out to ensure evacuation of renewable energy.

- Partial Risk Guarantee Fund for Energy Efficiency (PRGFEE), a risk sharing mechanism to provide financial institutions with a partial coverage of risk involved in extending loans for energy efficiency projects, and Venture Capital Fund for Energy Efficiency (VCFEE), a trust fund to provide "last mile" equity capital to energy efficiency companies, have been established.

- Perform, Achieve and Trade (PAT), as a market based energy efficiency trading mechanism, at present covers 478 plants (designated consumers) in eight energy-intensive industrial sectors accounting for one-third of total energy consumption in the country.

- Tax Free Infrastructure Bonds of INR 50 billion (USD 794 million) are being introduced for funding of renewable energy projects during the year 2015-16.

- Financial measures related to environmental goods and services

- Solar Power: A scheme for development of 25 Solar Parks, Ultra Mega Solar Power Projects, canal top solar projects and one hundred thousand solar pumps for farmers is at different stages of implementation. India is also promoting solarization of all the 55,000 petrol pumps across the country out of which about 3,135 petrol pumps have already been solarized.

- Incentives to promote faster adoption and manufacturing of hybrid and electric vehicles in the country (so-called FAME India programme).

\section{International cooperation (climate finance, technology transfer, international mechanisms etc.)}

- The Government's goal of Electricity for All would require huge investments, infusion of new technology, availability of nuclear fuel and international support.

- India's climate actions have so far been largely financed from domestic resources. A substantial scaling up of the climate action plans would require greater resources. A detailed and full scale assessment of international climate finance needs will be finalized at a later stage and would depend on the gap between actual cost of implementation of India's plans and what can be made available from domestic sources. While this would evolve over time, a preliminary estimate suggests that at least USD 2.5 trillion (at 2014-15 prices) will be required for meeting India's climate change actions between now and 2030. 


\section{GHG and non-GHG target:}

- In 2009 , Indonesia voluntarily pledged to reduce emission by $25 \%$ on its own efforts, and up to $41 \%$ with international support, against the BAU by 2020 . Beyond 2020 , Indonesia envisions an even bolder commitment to emission reductions. Based on the country's most recent emissions level assessment, the unconditional reductions target is $29 \%$ of the BAU scenario by 2030 . In order to support the beyond 2020 target, Indonesia recognized the need for consolidating both methods and data sources to ensure the high degree of accuracy.

\section{Measures related to the energy sector}

- Indonesia has embarked on a mixed energy use policy, with at lest $23 \%$ coming from new and renewable energy by $25 \%$

- Indonesia has established the development of clean energy sources as a national policy directive.

\section{Green industrial policies}

- None, but the INDC explicitly covers industrial processes and product use sector.

\section{Green government procurement}

- None.

Financial and direct trade measures (subsidies, carbon pricing, taxation, R\&D etc.)

- None.

\section{International cooperation (climate finance, technology transfer, international mechanisms etc.)}

- Indonesia welcomes bilateral, regional, and international market mechanisms that facilitate and expedite technology development and transfer, payment of performance, technical cooperation, and access to financial resources to support Indonesia's climate mitigation and adaptation efforts towards a climate resilient future. 


\section{GHG and non-GHG target:}

- On the basis of national capabilities, financial resources available and requirements of the national development program, taking into account GHGs emission scenarios, the Islamic Republic of Iran intends to participate by mitigating its GHGs emission in 2030 by $4 \%$ compared to the BAU scenario (unconditional). The Islamic Republic of Iran has the potential of mitigating additional GHGs emission up to $8 \%$ against the BAU scenario (i.e. $12 \%$ in total) (conditional).

\section{Measures related to the energy sector}

- Development of combined cycle power plants, renewable energies and nuclear power.

- Reduction of gas flare emissions.

- Substitution of high-carbon fuels with natural gas

- Strategic planning for utilizing low-carbon fuels.

\section{Green industrial policies}

- Access to new and environmentally sound technologies for industrial production.

- Increase in energy efficiency in various consuming sectors.

\section{Green government procurement}

- None.

Financial and direct trade measures (subsidies, carbon pricing, taxation, R\&D etc.)

- Reduction and gradual phasing out of energy subsidies.

- Formulation of a master plan to promote the role of private sector, particularly in the energy sector.

\section{International cooperation (climate finance, technology transfer, international mechanisms etc.)}

- Participation in market-based mechanisms at the national and international levels.

- The total annual investments needed to achieve unconditional and conditional GHGs mitigation are about 17.5 and 52.5 billion US dollars respectively. 


\section{GHG and non-GHG target:}

- Iraq intends to achieve a reduction of $14 \%$ compared to the BAU model during the period between 2020 and 2035. The target is divided into two parts. First, 1\% GHG reduction by 2035 (unconditional) and 13\% GHG reduction by 2035 conditional on the availability of international financial and technical assistance.

\section{Measures related to the energy sector}

- Use of renewable energy for electricity generation (conditional).

- Development of hydropower stations in Kurdistan which will result of $3.3 \%$ of hydropower generation (conditional).

- Use of Liquid Petroleum Gas for vehicles to reduce the consumption of gasoline (conditional).

- Creation of advanced refineries to improve the quality of petroleum products (conditional).

\section{Green industrial policies}

- Development of the production process to achieve a reduction in emissions in different industries, including the fertilizer industry (unconditional).

\section{Green government procurement}

- None.

Financial and direct trade measures (subsidies, carbon pricing, taxation, R\&D etc.)

- Development of specifications and standards for the import of vehicles and other equipment to make sure it does not exceed global emissions (conditional).

International cooperation (climate finance, technology transfer, international mechanisms etc.)

- The energy sector will require investment in clean, low-carbon and renewable energy. 


\section{GHG and non-GHG target:}

- Israel intends to achieve an economy-wide unconditional target of reducing its per capita greenhouse gas emissions to $7.7 \mathrm{tCO}_{2}$ e by 2030 which constitutes a reduction of $26 \%$ below the level in 2005 of $10.4 \mathrm{tCO}_{2}$ e per capita. An interim target of $8.8 \mathrm{tCO}_{2} \mathrm{e}$ per capita is expected by 2025. Energy efficiency - $17 \%$ reduction in electricity consumption relative to BAU scenario in 2030. Renewable energy $-17 \%$ of the electricity generated in 2030 will be from renewable sources. Public transport $-20 \%$ shift from private to public transportation.

\section{Measures related to the energy sector}

- None, but the INDC explicitly covers the energy sector.

- Measures to increase the use of natural gas.

- The government is working on the further development of gas fields, expected to have significant mitigation potential.

\section{Green industrial policies}

- None, but the INDC explicitly covers industrial processes and product use sector.

\section{Green government procurement}

- None.

Financial and direct trade measures (subsidies, carbon pricing, taxation, R\&D etc.)

- The establishment of mechanisms leveraging large scale private funding together with public funding for energy efficiency projects.

- Removal of barriers for the uptake of renewable energy.

- Financial measures related to environmental goods and services

$\circ$ A program of tenders for renewable energy.

International cooperation (climate finance, technology transfer, international mechanisms etc.)

- None. 


\section{GHG and non-GHG target:}

- Jamaica's intended nationally determined contribution will mitigate the equivalent of 1.1 million metric tons of carbon dioxide per year by 2030 versus the BAU scenario. This is a reduction of $7.8 \%$ of emissions versus BAU. This target is predicated on the current level of implementation of the National Energy Policy and the existing pipeline of renewable energy projects. Jamaica will conditionally increase its ambition to a reduction of GHG emissions of $10 \%$ below the BAU scenario, subject to the provision of international support.

\section{Measures related to the energy sector}

- Jamaica realizes its energy resource potential through the development of renewable energy sources by increasing the share of renewable sources of energy in its primary energy mix to $20 \%$ by 2030.

\section{Green industrial policies}

- None, but the INDC explicitly covers the industrial processes sector.

\section{Green government procurement}

- None.

Financial and direct trade measures (subsidies, carbon pricing, taxation, R\&D etc.)

- Mobilization of climate financing for adaptation and mitigation initiatives.

- Enhancement of research capacities (e.g. at Universities, National Meteorological Service) to undertake climate variability research specific to Jamaica.

International cooperation (climate finance, technology transfer, international mechanisms etc.)

- None. 


\section{GHG and non-GHG target:}

- Japan's INDC towards post-2020 GHG emission reductions is at the level of a reduction of $26.0 \%$ by fiscal year (FY) 2030 compared to FY 2013 (25.4\% reduction compared to FY 2005) (approximately 1.042 billion t- $\mathrm{CO}_{2}$ eq. as 2030 emissions), ensuring consistency with its energy mix, set as a feasible reduction target by bottom-up calculation with concrete policies, measures and individual technologies taking into adequate consideration, inter alia, technological and cost constraints, and set based on the amount of domestic emission reductions and removals assumed to be obtained.

\section{Measures related to the energy sector}

- Expansion of renewable energy introduction to the maximum extent possible.

- Use of nuclear power generations whose safety is confirmed.

- Pursuit of high efficiency in thermal power generation.

\section{Green industrial policies}

- Iron and steel industry: efficiency improvement of electricity-consuming facilities; more chemical recycling of waste plastic at steel plants; introduction of next-generation coke making process (SCOPE21); improvement of power generation efficiency; enhanced energy efficiency and conservation facilities; introduction of innovative ironmaking process (Ferro Coke); introduction of environmentally harmonized steelmaking process.

- Chemical industry: introduction of energy efficiency and conservation process technology in petrochemicals; introduction of energy efficiency and conservation technology using membranes for distilling process; introduction of technology which uses CO2 as a feedstock; introduction of chemical product production technology with inedible plant-based material; introduction of electricity-generating waste water processing with microbe catalysis; introduction of sealed plant factory.

- Ceramics, stone and clay products industry: introduction of conventional energy efficiency and conservation technologies (waste heat power generation, slag crusher, air-beam cooler, separator improvement, vertical roller coal mills); introduction of technology for using waste (e.g. waste plastic, etc.) as alternative thermal energy; introduction of innovative cement production process; introduction of glass melting process.

- Pulp/paper/paper products manufacture industry: introduction of high-efficient pulp production technology using old paper; introduction of high-temperature and pressure recovery boilers.

- Cross-sectoral: introduction of high-efficient air conditioner; introduction of industrial HP (heating-drying); introduction of industrial light; introduction of low-carbon industrial furnace; introduction of industrial motor; introduction of high performance boiler; direct use of recycled plastic flakes; introduction of hybrid construction machine;

- Factory energy management: thorough implementation of energy management in the industry sector.

- Promotion and enhancement of the industries' action plans towards a low carbon society.

- Promotion of cooperative energy efficiency and conservation measures across industries.

\section{Green government procurement}


- None.

Financial and direct trade measures (subsidies, carbon pricing, taxation, R\&D etc.)

- None.

International cooperation (climate finance, technology transfer, international mechanisms etc.)

- Japan will actively contribute internationally towards, inter alia, human resource development and promotion of development and diffusion of technologies relating to emission reductions in developing countries. 


\section{GHG and non-GHG target:}

- Jordan nationally determines to reduce its greenhouse gas emissions by a bulk of $14 \%$ until 2030 . This contribution of GHGs reduction will be unconditionally fulfilled at, maximally, $1.5 \%$ by the Country's own means compared to a BAU scenario level. However, Jordan, conditionally and subject to availability of international financial aid and support to means of implementation, commits to reduce its GHGs emissions by additional, at least, 12.5 \% by 2030.

\section{Measures related to the energy sector}

- Jordan has set a KPI-style "target" of $11 \%$ of renewable energy share in the total energy mix in 2025.

\section{Green industrial policies}

- Expansion of the use of solar cooling in commercial and industrial facilities: Jordan has been experimenting the application of solar cooling technologies for use in commercial buildings and industrial process to help in introducing sustainable energy systems and reducing GHG emissions from the cooling sector.

- Encouragement of investment in solar and wind energy projects near industrial clusters.

\section{Green government procurement}

- None.

\section{Financial and direct trade measures (subsidies, carbon pricing, taxation, R\&D etc.)}

- Improvement of the attractiveness of renewable electricity tariff by basing the purchase price on the cost of production (depending on the energy source and size of the project).

- Implementation of power purchase agreements on the long-term from renewable energy producers.

- Activation of the recently established Renewable Energy and Energy Efficiency Fund (JREEEF).

- Provision of appropriate financial incentives for energy efficiency projects.

- Provision of funding to allow schools, hospitals and other facilities assessing the potential of saving energy, and making energy-related capital improvements in their facilities.

- Financial measures related to environmental goods and services

$\circ$ Encouragement of use of solar energy for water heating: through the provision of shortterm support for the purchase of solar water heaters.

- Encouragement and support to local industries to manufacture renewable energy components.

\section{International cooperation (climate finance, technology transfer, international mechanisms etc.)}

- Attracting private sector investment to the energy sector: Reducing administrative obstacles in order to take advantage of the JREEEF to support investment in early stage. 
- The estimated cost to reach the $14 \%$ target is totaling USD 5,700,000,000 from which Government of Jordan has already secured USD $542,750,000$ by its own means to meet the unconditional target; which means the Country is in need of USD 5,157,250,000 to fulfill its conditional target. 
GHG and non-GHG target:

- The Republic of Kazakhstan intends to achieve an economy-wide target of $15 \%$ (unconditional)$25 \%$ (conditional) reduction in greenhouse gas emissions by 2030 compared to 1990 subject to additional international investments, access to low carbon technologies transfer mechanism, green climate funds and flexible mechanism for country with economy in transition.

\section{Measures related to the energy sector}

- Greater use of renewable energy sources.

\section{Green industrial policies}

- Laws on extended responsibility of entrepreneurs and greening of vehicles are being formulated.

- Modernisation of key infrastructure and production technologies based on energy-efficient technologies.

\section{Green government procurement}

- None.

Financial and direct trade measures (subsidies, carbon pricing, taxation, R\&D etc.)

- None.

International cooperation (climate finance, technology transfer, international mechanisms etc.)

- Kazakhstan supports inclusion of market based mechanisms in the 2015 agreement, and the opportunity to use carbon units recognised by the UNFCCC.

- Kazakhstan retains the option of using market-based mechanisms under the UNFCCC.

- Kazakhstan will consider adequately discounting international units for compliance to ensure a contribution to net global emission reductions. 


\section{KENYA}

\section{GHG and non-GHG target:}

- Kenya seeks to abate its GHG emissions by $30 \%$ by 2030 relative to the BAU scenario of 143 $\mathrm{MtCO} 2 \mathrm{eq}$; and in line with its sustainable development agenda. This is also subject to international support in the form of finance, investment, technology development and transfer, and capacity building.

\section{Measures related to the energy sector}

- Expansion in geothermal, solar and wind energy production, other renewables and clean energy options.

- Clean energy technologies to reduce overreliance on wood fuels.

\section{Green industrial policies}

- None.

\section{Green government procurement}

- None.

Financial and direct trade measures (subsidies, carbon pricing, taxation, R\&D etc.)

- None.

International cooperation (climate finance, technology transfer, international mechanisms etc.)

- Kenya does not rule out the use of international market-based mechanisms in line with agreed accounting rules.

- Kenya's contribution will be implemented with both domestic and international support. It is estimated that over USD 40 billion is required for mitigation and adaptation actions across sectors up to 2030. Kenya will require international support in form of finance, investment, technology development and transfer, and capacity building to fully realize her intended contribution. Further analysis will be necessary to refine the required investment cost and determine the domestic support. 


\section{GHG and non-GHG target:}

- Kiribati is a LDC SIDS with limited resources that will nonetheless commit to reduce emissions by $13.7 \%$ by 2025 and $12.8 \%$ by 2030 compared to a BaU projection.

- On the understanding that a global agreement addresses international assistance to access financial and technical resources, Kiribati can, with international assistance, contribute a further:

○ $48.8 \%$ reduction in greenhouse gas emissions by 2025 ; and

- $49 \%$ reduction in greenhouse gas emissions by 2030, compared to the BaU projection. With appropriate international assistance, Kiribati can reduce its emissions by more than $60 \%(61.8 \%)$ by 2030.

\section{Measures related to the energy sector}

- Reducing fossil fuel imports is the major goal, with the uptake of renewable energy along with further energy efficiency improvements on both the demand and supply sides, expected to replace more than one-third of fossil fuels for electricity and transport by 2025.

- Kiribati has identified targets focused on reductions in fossil fuel use by 2025 through increases in renewable energy and energy efficiency (RE and $E E$ ) in the following sectors and geographical areas:

O South Tarawa by $45 \%$ (23\% RE and $22 \%$ EE);

○ Kiritimati Island by $60 \%$ (40\% RE and $20 \%$ EE);

- Rural public infrastructure, including Southern Kiribati Hospital and Ice plants by $60 \%$ (40\% RE and $20 \%$ EE);

- Rural public and private institutions such as boarding schools, Island Council, private amenities and households by $100 \%(100 \%$ RE).

- Outer Island and rural electrification (off-grid solar).

- Use of coconut oil as biodiesel for electricity generation and transportation (conditional).

\section{Green industrial policies}

- None.

\section{Green government procurement}

- None.

Financial and direct trade measures (subsidies, carbon pricing, taxation, R\&D etc.)

- None.

\section{International cooperation (climate finance, technology transfer, international mechanisms etc.)}

- Kiribati will consider market-based mechanisms to support establishment and operation of a National Climate Change Trust Fund. 


\section{GHG and non-GHG target}

- With domestic resources, Democratic People's Republic of Korea intends to reduce GHG emissions by $8.0 \%$ by 2030 compared to a BAU scenario. The national contribution could be increased up to $40.25 \%$ with international support.

\section{Measures related to the energy sector}

- Construction and scaling up of power plants based on renewable energy resources.

- Generalization of off-grid power generating system based on the renewable energy.

- Construction of nuclear power stations.

- Efficiency improvements in the existing coal-fired power plants.

- Construction of eco-friendly large, medium and small scale hydro power station, and efficiency improvements in hydro power stations.

- Completion of the flexible electric power transmission system and introduction of ultra-high tension transmission technologies.

\section{Green industrial policies}

- Improvement of the energy efficiency of technologies and processes in industrial sector.

- Establishment of standards on energy consumption of major technologies and products.

- Dissemination of the technologies for zero-energy, zero carbon architecture.

- Improvements in the fuel-economics of vehicles.

\section{Green government procurement}

- None.

Financial and direct trade measures (subsidies, carbon pricing, taxation, R\&D etc.)

- DPR Korea commits to innovate in the application of funds and explore new investment and financing mechanisms for low-carbon development.

International cooperation (preferential access, technology transfer, international mechanisms etc.)

- Enhancement of international cooperation capacity building, joint research, sci-tech knowledge exchange and demonstration activities. 


\section{GHG and non-GHG target:}

- Republic of Korea plans to reduce its greenhouse gas emissions by $37 \%$ from the business-as-usual (BAU, $850.6 \mathrm{MtCO}$ eq) level by 2030 across all economic sectors. The key sectors include energy, industrial processes and product use, agriculture and waste. A decision on whether to include land use change and forestry (LULUCF) will be made at a later stage.

- Korea announced its voluntary mitigation target in 2009 to reduce greenhouse gas emissions by $30 \%$ from the Business-as-Usual (BAU) level by 2020.

\section{Measures related to the energy sector}

- Korea obligated the power generators to supply a portion of electricity from renewable sources and its increasing the production of renewable energy in order to reduce greenhouse gas emissions from fossil fuel. Korea also supports the installation of facilities for the generation of renewable energy.

\section{Green industrial policies}

- Introduction of low-carbon standards for fuel efficiency and emissions produced from automobiles. Korea decided to strengthen the average emission standard from $140 \mathrm{~g} / \mathrm{km}$ in 2015 in 97g/km in 2020.

- Korea's mitigation potential is limited due to its industrial structure with a large share of manufacturing (32\% as of 2012) and the high energy efficiency of major industries.

- In 2012, Korea launched the GHG and Energy Target Management System (TMS) for the industrial sector. The reduction through the TMS exceeded its industrial sectoral target for mitigation.

- In building sector, the Korean Government is seeking to manage energy efficiency from the design stage to the operation stage by means such as establishing the Green Building Standards Code and a system for the Performance Evaluation of Eco-friendly Homes.

- Korea established a domestic MRV system to monitor businesses with large amounts of greenhouse gas emissions in the industry, power generation, building and transport sectors.

\section{Green government procurement}

- None.

Financial measures (subsidies, carbon pricing, taxation, R\&D, etc.)

- Korea adopted the Act on the Allocation and Trading of Greenhouse Gas Emission Permits in 2012, and launched a nation-wide Emissions Trading Scheme (ETS) in 2015. The ETS covers 525 business entities which account for $67.7 \%$ of national greenhouse gas emissions.

- Financial measures related to environmental goods and services

o The Korean government provides various incentives, including tax reductions for electric and hybrid vehicles in order to promote low-carbon vehicles.

International Cooperation (climate finance, technology transfer, international mechanisms etc.)

- Korea will partly use carbon credits from international market mechanisms. 
GHG and non-GHG target:

- The State of Kuwait is ambitious to move to a low carbon equivalent economy and to avoid the increase in greenhouse gas emissions compared to BAU patterns, based on plans and development projects in the country, and it is working on achieving this goal on a voluntary basis through the implementation of some projects and enacting laws and regulations, according to its national circumstances, which is Subjected to the availability of financial, technical and technological support through the mechanisms of the Convention. Note that the amount of the reduction resulted from the proposed projects will be estimated later.

\section{Measures related to the energy sector}

- Improvement of petroleum products through producing clean fuel according to environmental specifications to supply power plants with it by 2020, this project will reduce greenhouse gas emissions from power plants and industrial sector in the state significantly.

- Construction of a new refinery to replace the state's oldest refinery, which will meet international environmental standards in the way that the refinery will operate, where the amount of emissions will be low and the products of this refinery will be compatible with international specifications and standards.

- Projects related to energy production from municipal solid waste where the first project will start operating by 2020.

- Energy production from renewable sources (photovoltaic energy - solar thermal energy - wind energy), which is expected to reach the maximum production capacity of these projects by 2030.

\section{Green industrial policies}

- None.

\section{Green government procurement}

- Article (122) and (123) of Environment Protection Law mentions the need to use energy-saving systems in the new state facilities.

Financial and direct trade measures (subsidies, carbon pricing, taxation, R\&D etc.)

- Kuwait began the formal procedures to examine the law of reducing part of government gasoline subsidies starting from the beginning of 2016 and to study the possibility of a gradual reduction of subsidies on electricity and water, which will contribute significantly to rationalize consumption and reducing greenhouse gas emissions.

- Financial measures related to environmental goods and services

$\circ$ Environmental Protection law prevents importing any hardware or equipment that does not match the specifications of energy conservation.

\section{International cooperation (climate finance, technology transfer, international mechanisms etc.)}

- The State of Kuwait will suffer from economic and social consequences of negative impacts of response measures, where Kuwait is considered one of the countries that its economy 
dependent on oil and will be affected negatively from international policies and procedures of the UNFCCC.

- Kuwait needs the availability of technological and financial support by the relevant existing institutions under the Framework Convention such as technological mechanisms consisting of the Technology Executive Committee (TEC) and the Climate Technology Centre \& Network (CTCN), as well as the Green Climate Fund (GCF). 


\section{GHG and non-GHG target:}

- Kyrgyz Republic will reduce GHG emissions in the range of $11.49-13.75 \%$ below BAU in 2030 . Additionally, under the international support Kyrgyz Republic could implement the mitigation measures to achieve total reduction in the range of $29.00-30.89 \%$ below BAU in 2030.

- Kyrgyz Republic will reduce GHG emissions in the range of $12.67-15.69 \%$ below BAU in 2050 . Additionally, under the international support Kyrgyz Republic could implement the mitigation measures to achieve total reduction in the range of $35.06-36.75 \%$ below BAU in 2050 .

\section{Measures related to the energy sector}

- None, but the INDC explicitly covers the energy sector.

\section{Green industrial policies}

- None, but the INDC explicitly covers the industrial processes sector.

\section{Green government procurement}

- None.

Financial and direct trade measures (subsidies, carbon pricing, taxation, R\&D etc.)

- None.

International cooperation (climate finance, technology transfer, international mechanisms etc.)

- None. 


\section{GHG and non-GHG target:}

- Lao PDR is committed to an anticipated emission reductions of 1,468,000 ktCO2e by 2025.

\section{Measures related to the energy sector}

- Lao PDR aims at utilising unexploited hydropower resources to export clean electricity to its neighbours.

- Development of an overall renewable energy policy.

- Set-up objectives and goals based on resource potentials and develop renewable energy database.

- Studies and demonstration projects utilising renewable energy technologies.

\section{Green industrial policies}

- None.

\section{Green government procurement}

- None.

Financial and direct trade measures (subsidies, carbon pricing, taxation, R\&D etc.)

- The Central Bank of Lao PDR will consider carbon credits and low interest loans as sources of financing for renewable energy projects and activities, agricultural promotion and fuel crops plantation development and projects carried out by small and medium enterprises

- Financial measures related to environmental goods and services

$\circ$ The Ministry of Finance determines appropriate tax and duties policies for land use, vehicles and equipment to be used for renewable energy projects while at the same time assisting in raising funds for renewable energy development.

International cooperation (climate finance, technology transfer, international mechanisms etc.)

- The estimated cost is USD 658.75 million (2007-2030) including investment costs, operation and management costs and financial costs. 


\section{GHG and non-GHG target:}

Unconditional:

- A GHG emission reduction of $15 \%$ compared to the BAU scenario in 2030.

- $15 \%$ of the power and heat demand in 2030 is generated by renewable energy sources.

- A 3\% reduction in power demand through energy-efficiency measures in 2030 compared to the demand under the BAU scenario.

Conditional:

- A GHG emission reduction of 30\% compared to the BAU scenario in 2030.

- $20 \%$ of the power and heat demand in 2030 is generated by renewable energy sources.

- A $10 \%$ reduction in power demand through energy-efficiency in 2030 compared to the demand under the BAU scenario.

\section{Measures related to the energy sector}

- None, but the INDC explicitly covers the energy sector.

\section{Green industrial policies}

- None, but the INDC explicitly covers the industrial processes sector.

\section{Green government procurement}

- None.

Financial and direct trade measures (subsidies, carbon pricing, taxation, R\&D etc.)

- None.

International cooperation (climate finance, technology transfer, international mechanisms etc.)

- None. 


\section{GHG and non-GHG target:}

- Lesotho is committed to reduce unconditionally $10 \%$ of its GHG emissions by 2030 compared to a BAU scenario. The conditional target is $35 \%$ by 2030 .

\section{Measures related to the energy sector}

- Continued development of hydropower resources, particularly in terms of advancing technical design and sourcing funding for development of identified sites.

- Continued development and promotion of uptake of renewable sources of energy, particularly wind and solar (where feasible).

- Develop low energy investment plan.

\section{Green industrial policies}

- Design and implementation of guidelines and/or standards and regulations for design of new buildings.

\section{Green government procurement}

- Investments in fuel-efficient vehicles for public transportation.

Financial and direct trade measures (subsidies, carbon pricing, taxation, R\&D etc.)

- Promotion of new and renewable energy technologies.

- Implementation of energy efficiency measures, including the removal of institutional barriers to energy efficiency improvements.

International cooperation (climate finance, technology transfer, international mechanisms etc.)

- Lesotho needs international support (provision of finance, capacity building and technology).

- In the period 2015-2030, additional investments (relative to BAU scenario) needed for realization of the mitigation scenario are estimated at USD 1.2 billion, while for realization of the higher ambition mitigation scenario are estimated at USD1.8 billion.

- The energy sector will require investment of about USD 15 million in 2020 and USD 20 million in 2030. These investments will be needed in energy-efficient equipment, grid extension; rural electrification projects (off- grids and mini-grids) that are ultimately expected to reduce emissions significantly. However, Lesotho cannot afford these levels of investment without financial support.

- Lesotho remains open to the possibility of using of international market-based mechanisms in line with agreed accounting rules to achieve its conditional and/or unconditional targets. 


\section{GHG and non-GHG target:}

- Liberia conditionally commits to reduce GHGs by $15 \%$ from the BAU trajectory (797 000 tCO2e). The timeframe for implementation of the INDC mitigation and adaptation actions is up to 2030 in line with Liberia's Agenda for Transformation (AfT). The long-term strategy for Liberia is to achieve carbon neutrality by 2050.

\section{Measures related to the energy sector}

- Increase in the share of renewable energy to at least $30 \%$ of electricity production and $10 \%$ of overall energy consumption by 2030.

- Rehabilitation of existing hydro-power plants and build new hydro-power plants to increase hydro-power production capacity.

- Implementation of large-scale biomass projects to generate about 30 MW by 2030.

- Implementation and strengthening of policies that promotes private investment in renewable energy (hydro, biomass and solar etc.).

\section{Green industrial policies}

- Development of technical and safety standards and the enforcement of policies including emission control.

- Development of emission reduction and tracking system of pollutants from vehicles.

\section{Green government procurement}

- None.

\section{Financial and direct trade measures (subsidies, carbon pricing, taxation, R\&D etc.)}

- None.

\section{International cooperation (climate finance, technology transfer, international mechanisms etc.)}

- The extent of implementation of the intended contributions on mitigation and adaptation are conditioned upon the provision of adequate means of implementation by the international community (financial resources, capacity building and the transfer of technologies). It does not constitute an international obligation to Liberia.

- Liberia does not rule out the inclusion of international carbon market mechanisms such as the Clean Development Mechanism (CDM) in a post 2020 climate agreement. 


\section{LIECHTENSTEIN}

GHG and non-GHG target:

- Liechtenstein aims at a reduction of greenhouse gases by $40 \%$ compared to 1990 by 2030, which corresponds to per capita emissions of $3.6 \mathrm{CO}_{2} \mathrm{eq}$. The reduction target will be subject to the approval of the Liechtenstein Parliament.

\section{Measures related to the energy sector}

- Liechtenstein aims to invest in emission reduction projects of high quality standards, which besides the mitigation of GHGs also lead to social, health, and environmental benefits.

\section{Green industrial policies}

- None, but the INDC explicitly covers the industrial processes sector.

\section{Green government procurement}

- None.

Financial and direct trade measures (subsidies, carbon pricing, taxation, R\&D etc.)

- None.

International cooperation (climate finance, technology transfer, international mechanisms etc.)

- None. 


\section{GHG and non-GHG target:}

- The Republic of Macedonia aims to reduce the $\mathrm{CO} 2$ emissions from fossil fuels combustion for $30 \%$, that is, for $36 \%$ at a higher level of ambition, by 2030 compared to the business as usual (BAU) scenario. The $\mathrm{CO} 2$ emissions from fossil fuels combustion cover almost $80 \%$ of the total GHG emissions in the country with a dominant share of the following sectors: energy supply, buildings and transport.

Measures related to the energy sector

- None.

Green industrial policies

- None.

\section{Green government procurement}

- None.

Financial and direct trade measures (subsidies, carbon pricing, taxation, R\&D etc.)

- None.

International Cooperation (climate finance, technology transfer, international mechanisms etc.)

- None. 


\section{GHG and non-GHG target:}

- In 2030, Madagascar aims to reduce approximately 30 MtCO2 of its emissions of GHG, representing $14 \%$ of national emissions, compared to the BAU scenario, with projections based of GHG inventory from year 2000 to 2010. This reduction is additive to the absorptions increase of the LULUCF sector, which estimated at $61 \mathrm{MtCO} 2$ in 2030. Total increase in GHG absorption is expected at $32 \%$, compared to the BAU scenario. However, these objectives remain conditioned by financial support, which will be received from global partners (conditional contributions).

\section{Measures related to the energy sector}

- Rehabilitation of energy producing network and plant stations.

- Rural electrification.

- Reinforcement of renewable energy (hydraulic and solar) from the current level of $35 \%$ to $79 \%$.

\section{Green industrial policies}

- Improvements in energy efficiency.

\section{Green government procurement}

- None.

Financial and direct trade measures (subsidies, carbon pricing, taxation, R\&D etc.)

- Facilitation of access to energy by strengthening existing systems and by promoting renewable and alternative energies.

\section{International cooperation (climate finance, technology transfer, international mechanisms etc.)}

- The Costs associated with the implementation of this INDC are estimated at 42.099 billion US dollars. Given the precarious economic situation of Madagascar, the implementation of the INDC is conditioned by the availability of external financial support, especially through the financial mechanisms under the UNFCCC but also through other multilateral and bilateral sources. The effective implementation of Madagascar's contributions requires the reinforcement of the national capacities (technical, institutional, mobilisation and absorption of funding) and transfer of technology and research from developed countries, as well as the contributions of countries and other stakeholders that are actively involved in the fight against climate change. 


\section{GHG and non-GHG target:}

- Malawi Government expresses its intentions to contribute towards global efforts to reduce GHG emissions. Emission reduction efforts will concentrate in key sectors of forestry, agriculture and energy. Implementing all unconditional and conditional mitigation activities is expected to reduce the per capita emissions of Malawi from $1.4 \mathrm{t} \mathrm{CO}_{2} \mathrm{e}$ per capita in 2010 to around 0.7 to $0.8 \mathrm{t} \mathrm{CO}_{2} \mathrm{e}$ per capita in 2030 compared to expected BAU emissions of around $1.5 \mathrm{t} \mathrm{CO}_{2}$ e per capita in 2030. Potential reductions from the energy sector will be additional to the expected overall per capita GHG emissions reduction.

\section{Measures related to the energy sector}

- Production of 2000 solar water heaters (SWH) and increase SWH from 2,000 to 20,000 by 2030.

- Installation of 20,000 solar PV systems and increase Solar PV from 20,000 to 50,000 by 2030

- Production of 2 million litres of bio-diesel/year and increase biodiesel from 2 to 20 million/ year

- Production of million litres of ethanol/ year and increase ethanol production from 18 to 40 million litres per year

- Production of $351 \mathrm{MW}$ of hydro electricity

- Increase in the generation of HEP by $800 \mathrm{MW}$ by 2025

\section{Green industrial policies}

- Increase in the use of soil-cement stabilized block and rice husk ash blended cement to around $10 \%$ of current cement production.

- Development of international standards for alternative building materials and technologies

\section{Green government procurement}

- None.

\section{Financial and direct trade measures (subsidies, carbon pricing, taxation, R\&D etc.)}

- Support to industries engaged in carbon capture and storage

- Support to research and use of alternative cement materials

\section{International cooperation (climate finance, technology transfer, international mechanisms etc.)}

- The implementation of mitigation and adaptation actions indicated will require availability of financial resources, technology development and transfer, and capacity building from the international community. The Government of Malawi is willing to implement some of the adaptation and mitigation actions indicated as unconditional' by pulling resources from domestic sources. 


\section{GHG and non-GHG target:}

- Malaysia intends to reduce its greenhouse gas (GHG) emissions intensity of GDP by $45 \%$ by 2030 relative to the emissions intensity of GDP in 2005 . This consists of $35 \%$ on an unconditional basis and a further $10 \%$ is condition upon receipt of climate finance, technology transfer and capacity building from developed countries.

\section{Measures related to the energy sector}

- Since 2006, Malaysia has started initiatives to increase the share of use of non-fossil fuel energy.

- $\quad$ The National Biofuel Industry Act 2007 was put in place to regulate the biofuel industry and to promote the mandatory use of the B5 domestic blend of $5 \%$ palm biodiesel and $95 \%$ fossil fuel diesel.

\section{Green industrial policies}

- None, but the INDC explicitly covers the industrial processes sector.

\section{Green government procurement}

- None.

Financial and direct trade measures (subsidies, carbon pricing, taxation, R\&D etc.)

- The introduction of a feed- in-tariff (FiT) mechanism in conjunction with the Renewable Energy Policy and Action Plan (2010) to help finance renewable energy investment.

- Promotion of projects eligible for carbon credits.

- Provision of fiscal incentives and funding for green technology investments.

International cooperation (climate finance, technology transfer, international mechanisms etc.)

- None. 


\section{GHG and non-GHG target:}

- Unconditional Reductions

- Maldives intends to reduce unconditionally $10 \%$ of its Greenhouse Gases (below BAU) for the year 2030.

- Conditional Reduction

- The $10 \%$ reduction expressed above could be increased up to $24 \%$ in a conditional manner, in the context of sustainable development, supported and enabled by availability of financial resources, technology transfer and capacity building.

\section{Measures related to the energy sector}

- None, but the NDC explicitly mentions the energy sector.

\section{Green industrial policies}

- None.

\section{Green government procurement}

- None.

Financial and direct trade measures (subsidies, carbon pricing, taxation, R\&D etc.)

- None.

\section{International cooperation (climate finance, technology transfer, international mechanisms etc.)}

- The successful implementation of both adaptation and mitigation actions and undertakings of the Maldives require provisions of adequate and predictable financial resources, transfer of environmentally sound technologies and capacity building support.

- Sustainable finance remains a major challenge in addressing climate. Domestic budgetary spending on addressing climate change remains an additional burden towards the achievement of sustainable development. Nevertheless, public finance is being allocated to meet urgent and immediate adaptation actions. However, international support is necessary to address the adverse impacts of climate change facing the islands of the Maldives.

- Creating sustainable financing mechanisms for programmes related to climate change activities.

- Establishment of a Maldives Climate Resilient Fund to finance climate change adaptation and mitigation programs. 


\section{GHG and non-GHG target:}

- The Republic of Mali commits to reduce the level of GHG reduction relative to the baseline scenario (29\% for agriculture, $31 \%$ for energy and $21 \%$ for forests).

- The ambitions for reducing emissions of the mitigation scenario are $1486 \mathrm{kteq}$ CO2 in 2025, a $22.4 \%$ reduction, and 2933 kteq CO2 in 2030 , a $31.6 \%$ reduction. The corresponding cost is $\$ 580$ million US over five years, or US $\$ 1.16$ billion over ten years.

\section{Measures related to the energy sector}

- Large-scale development program for renewable energy (SREP) for US \$ 258 million.

- The Manantali II project will be implemented between 2016 and 2021 and will cost US \$150 million.

- The village electrification project by renewable energy system which will be implemented between 2015 and 2020 and will cost US \$ 7.2 million.

- The project of the hydroelectric Kénié to be conducted between 2015 and 2020 and will cost US \$165 million.

\section{Green industrial policies}

- None.

\section{Green government procurement}

- None.

Financial and direct trade measures (subsidies, carbon pricing, taxation, R\&D etc.)

- None.

International cooperation (climate finance, technology transfer, international mechanisms etc.)

- None. 


\section{GHG and non-GHG target:}

- The Republic of Marshall Islands commits to a quantified economy-wide target to reduce its emissions of greenhouse gases (GHG) to 32\% below 2010 levels by 2025.

- The Republic of Marshall Islands communicates, as an indicative target, its intention to reduce its emissions of GHGs to 45\% below 2010 levels by 2030 .

\section{Measures related to the energy sector}

- Ground and roof mounted solar with associated energy storage.

- Supply-side energy efficiency improvements (e.g. new engines and system upgrades, heat recovery from engines).

- Small scale wind-powered electricity generation.

- Replantation and expansion of coconut oil production for use in electricity and transport sectors blended with diesel.

- Reduction in methane production in landfills through pre-sorting of waste and entrapment of methane.

- Additional GHG reductions may become possible through the use of new technologies allowing the extraction of ocean energy for power generation.

\section{Green industrial policies}

- Introduction of electric vehicles, and emission standards for current vehicles.

- Ongoing demand-side energy efficiency improvements (e.g. prepayment meters, end user efficiency improvements).

- Vehicle inspections and maintenance.

\section{Green government procurement}

- None.

Financial and direct trade measures (subsidies, carbon pricing, taxation, R\&D etc.)

- None.

International cooperation (climate finance, technology transfer, international mechanisms etc.)

- The Republic of Marshall Islands looks to regional and global cooperation for support in pursuit of these mitigation and adaptation measures. While RMI considers its INDC as a full national commitment to be undertaken without pre- conditions, the country is at present heavily reliant on external assistance for capacity and financial resources in key national sectors. 


\section{GHG and non-GHG target:}

- The Islamic Republic of Mauritania intends to contribute to the Paris Agreement of climate by reducing GHG emissions in 2030 of $22.3 \%, 4.2$ million tonnes of carbon dioxide equivalent (Mt CO2 eq) compared to projected emissions for that year in the normal course of BAU scenario that evolves from 6.6 Mt CO2 eq in 2010 to $18.84 \mathrm{Mt} \mathrm{CO} 2$ eq in 2030. Thus, for the 2020-2030 accumulated emissions avoided by the proposed mitigation measures are about $33,56 \mathrm{Mt} \mathrm{CO} 2 \mathrm{eq}$.

- $12 \%$ of this potential reduction in emissions can be achieved by the domestic sources of Mauritania (unconditional part of the Contribution).

- $88 \%$ of the contribution, corresponding to the share of emissions reduction conditioned on international support (conditional share of the contribution).

\section{Measures related to the energy sector}

- None, but the INDC explicitly covers the energy sector.

\section{Green industrial policies}

- None, but the INDC explicitly covers industrial processes and product use sector.

\section{Green government procurement}

- None.

Financial and direct trade measures (subsidies, carbon pricing, taxation, R\&D etc.)

- None.

International cooperation (climate finance, technology transfer, international mechanisms etc.)

- To achieve its ambitions mitigation of GHG in 2030, Mauritania will need an overall budget of 9.3 billion US Dollars of which $88 \%$ (equivalent to 8.2 Billion US dollars) to come from the international support. 


\section{GHG and non-GHG target:}

- The Republic of Mauritius imperatively needs international technical and financial support to enable it to abate its greenhouse gas emissions by $30 \%$, by the year 2030 , relative to the BAU scenario of 7 million metric tonnes $\mathrm{CO}_{2}$ equivalent.

\section{Measures related to the energy sector}

- Expansion in solar, wind and biomass energy production and other renewable energy sources.

- Gradual shift towards the use of cleaner energy technologies, such as LNG, among others.

- Modernisation of the national electricity grid through the use of smart technologies, which is a prerequisite to accelerate the uptake of renewable energy.

- Efficient use of energy through the deployment of appropriate technologies in all sectors of the economy and awareness raising on energy conservation.

\section{Green industrial policies}

- Efficient use of energy through the deployment of appropriate technologies in all sectors of the economy and awareness raising on energy conservation.

\section{Green government procurement}

- Sustainable transportation, including promotion of energy efficient mass transportation systems based on hybrid technologies and cleaner energy sources.

\section{Financial and direct trade measures (subsidies, carbon pricing, taxation, R\&D etc.)}

- None.

\section{International cooperation (climate finance, technology transfer, international mechanisms etc.)}

- The proposed adaptation and mitigation activities can only be implemented in the medium and long term with necessary support from international funding agencies, grants from climate funds, transfer of appropriate and affordable adaptation and mitigation technologies, technical assistance and capacity development.

- The implementation of the INDC of the Republic of Mauritius will require over USD 1.5 billion for mitigation measures and about USD 4 billion for adaptation measures across all the sectors up to 2030 in the form of finance, investment, technology development and transfer, and capacity-building to fully realize its intended contribution. 


\section{GHG and non-GHG target:}

- Unconditional Reduction: Mexico is committed to reduce unconditionally $25 \%$ of its Greenhouse Gases and Short Lived Climate Pollutants emissions (below BAU) for the year 2030. This commitment implies a reduction of $22 \%$ of $\mathrm{GHG}$ and a reduction of $51 \%$ of Black Carbon. This commitment implies a net emissions peak starting from 2026, decoupling GHG emissions from economic growth: emissions intensity per unit of GDP will reduce by around $40 \%$ from 2013 to 2030.

- Conditional Reduction: The $25 \%$ reduction commitment expressed above could increase up to a $40 \%$ in a conditional manner, subject to a global agreement addressing important topics including international carbon price, carbon border adjustments, technical cooperation, access to low- cost financial resources and technology transfer, all at a scale commensurate to the challenge of global climate change. Within the same conditions, GHG reductions could increase up to $36 \%$, and Black Carbon reductions to $70 \%$ in 2030 .

\section{Measures related to the energy sector}

- None, but the NDC explicitly covers the energy sector.

\section{Green industrial policies}

- None, but the NDC explicitly covers the industrial processes and product use sectors.

\section{Green government procurement}

- None.

Financial and direct trade measures (subsidies, carbon pricing, taxation, R\&D etc.)

- None.

\section{International cooperation (climate finance, technology transfer, international mechanisms etc.)}

- In order to achieve rapid and cost efficient mitigation, robust global market based mechanism will be essential. 


\section{GHG and non-GHG target:}

- The Federated States of Micronesia commits to unconditionally reduce by 2025 a $28 \%$ its GHGs emissions below emissions in year 2000.

- Similarly, subject to the availability of additional financial, technical and capacity building support from the international community, the Federated States of Micronesia could do by 2025 an additional reduction up to $35 \%$ below emissions in the 2000 base year.

\section{Measures related to the energy sector}

- None, but the NDC explicitly covers the energy sector.

\section{Green industrial policies}

- None.

\section{Green government procurement}

- None.

Financial and direct trade measures (subsidies, carbon pricing, taxation, R\&D etc.)

- None.

International cooperation (climate finance, technology transfer, international mechanisms etc.)

- Much will be needed for the implementation of the Federated States of Micronesia's INDC. An assessment of the implementation options is needed as soon as possible to ensure implementation no later than 2018. Potential sources will include the financial mechanisms of the Convention, other non-Convention financial and investments sources, as well as international, national and other financial sources. All these will be facilitated and enabled by public policy and regulatory frameworks. 
GHG and non-GHG target:

- The Republic of Moldova intends to achieve an economy-wide unconditional target of reducing its greenhouse gas emissions by $64-67 \%$ its 1990 level in 2030 and to make best efforts to reduce its emission by $67 \%$. The time frame of the commitment is from $1^{\text {st }}$ January 2021 till $30^{\text {th }}$ December 2030.

- Its achievement will be tracked periodically through the Moldova's Inventory of Greenhouse Gas Emissions and Sinks. The Moldova is committed to an unconditional target of a $64-67 \%$ reduction of its greenhouse gas emissions by 2030 compared to 1990 levels.

- The $64 \%$ reduction corresponds to a self-sufficiency power system development scenario, while the $67 \%$ reduction allows for a $30 \%$ import of electricity.

- The reduction commitment could increase up to $78 \%$ reduction below 1990 level conditional to a global agreement addressing important topics, including access to low-cost financial resources, technology transfer and technical cooperation commensurate to the challenge of global climate change.

\section{Measures related to the energy sector}

- Power production sector - 25\% GHG emissions reduction GHG emissions reduction compared to BAU scenario has to be achieved by 2020.

- Considerable abatement contributions a within the sector (533 ktep savings are envisaged from energy efficiency measures and 430 ktep savings from RES implementation covering the energy demand - the policy instrument in place envisage increasing the share of RES in the country's energy balance up to $20 \%$ by 2020 , and covering up to $10 \%$ of the electricity demand with locally produced renewable energy by 2020.

- By mid-2016, a draft Low Emission Development Strategy (LEDS) of the Republic of Moldova for the period up to 2030 will be developed. After consultations at the national level, the Low Emission Development Strategy of the Republic of Moldova until 2030 will be subject to approval by the Government by end of 2016.

- Mined Resources (oil and natural gas): replace water cooling systems with air cooling, dry cooling, or recirculating systems; improve design of gas turbines (inlet guide vanes, inlet air fogging, inlet air filters, compressor blade washing techniques, etc.

- Hydropower: Build de-silting gates, increase dam height; construct small dams in the upper basins; adapt capacity to flow regime (if increased); adapt plant operations to changes in river flow patterns; operational complementarities with other sources.

- Energy Transmission and Distribution: Improve robustness of pipelines and other transmission and distribution infrastructure; buying or cable re-rating of the power grid; emergency planning; and regular inspection of vulnerable infrastructure such as wooden utility poles.

- Research on efficiency of energy use in the context of global warming, with an emphasis on technologies and practices that save cooling energy and reduce electrical peak load.

\section{Green industrial policies}

- Buildings, industry and agriculture sectors - 20\% GHG emissions reduction compared to BAU scenario has to be reached by 2020 .

- Investments in high-efficiency infrastructure and equipment; investments in decentralized power generation such as rooftop PV generators; efficient use of energy through good operating practices.

\section{Green government procurement}


- None.

Financial and direct trade measures (subsidies, carbon pricing, taxation, R\&D etc.)

- None.

International cooperation (climate finance, technology transfer, international mechanisms etc.)

- In order to reach the conditional target of up to 78\% reduction of its greenhouse gas emissions by 2030 compared to 1990 levels, appropriate international financial support approximately equal to US\$ 4.9-5.1 billion, i.e. about US\$327-340 million per year until 2030, is needed; the support needed will be in additional to the domestic allocations to cover the required abatement costs. Along with the international financial support for covering the abatement costs, the country will also need assistance in the form of technology transfer and capacity building.

- The Republic of Moldova may use bilateral, regional and international market mechanisms to achieve its conditional 2030 target, subject to robust systems that deliver real and verified emissions reductions. The unconditional INDC commitment will be met through domestic actions, although these would assist cost-effective implementation. In order to avoid GHG emissions' double counting, an appropriate robust national MRV system will be put in place in the period of 2016-2017. It will cover the GHG emissions accounting from international bunkers and CDM projects as well, delivering real and verified emission reductions.

- The implementation of climate change adaptation objectives needs to be supported by appropriate financial mechanisms. The implementation cost of the Moldova's Climate Change Adaptation Strategy until 2020 and the Action Plan on its implementation is estimated at about US\$ 200 million. 


\section{GHG and non-GHG target:}

- The Principality of Monaco wishes to contribute to the joint effort by adopting a target to reduce its emissions by $50 \%$ by 2030, compared with the reference year of 1990 .

\section{Measures related to the energy sector}

- None.

\section{Green industrial policies}

- None.

\section{Green government procurement}

- Development of clean public transport.

Financial and direct trade measures (subsidies, carbon pricing, taxation, $R \& D$ etc.)

- None.

- Financial measures related to environmental goods and services

- Continued implementation of the Prince's Government's incentive policy for the purchase of electric and hybrid vehicles.

International cooperation (climate finance, technology transfer, international mechanisms etc.)

- The Principality of Monaco intends to achieve its emissions reduction target by implementing domestic measures. It does not, however, exclude the use of mechanisms for the international transfer of reduction units in the event that domestic emissions reductions prove insufficient at the end of the commitment period.

- The approaches envisaged by the Principality of Monaco are ambitious. They will require significant investment on the part of the Government but will also involve individuals and the private sector, which will need to adapt to new regulations. 


\section{GHG and non-GHG target:}

- Mongolia has outlined a series of policies and measures that the country commits to implement up to 2030, in the energy, industry, agriculture and waste sectors. The expected mitigation impact of these policies and measures will be a $14 \%$ reduction in total national GHG emissions excluding Land use, land use change and forestry (LULUCF) by 2030, compared to the projected emissions under a BAU scenario. Those and other potentially more ambitious commitments are contingent upon gaining access to new technologies and sources of finance through internationally agreed mechanisms and instruments under the auspices of the UNFCCC.

\section{Measures related to the energy sector}

- Increase in renewable electricity capacity from $7.62 \%$ in 2014 to $20 \%$ by 2020 and to $30 \%$ by 2030 as a share of total electricity generation capacity.

- Reduction of electricity transmission losses from $13.7 \%$ in 2014 to $10.8 \%$ by 2020 and to $7.8 \%$ by 2030 .

- Reduction of internal energy use of Combined Heat and Power plants (improved plant efficiency) from $14.4 \%$ in 2014 to $11.2 \%$ by 2020 and $9.14 \%$ by 2030 .

- Implementation of advanced technology in energy production (e.g. super critical pressure coal combustion technology by 2030).

\section{Green industrial policies}

- Reduction of emissions in the cement industry through upgrading the processing technology from wet- to dry- processing and through the construction of a new cement plant with dry processing up to 2030.

- Industry (motor-efficiency and housekeeping improvements).

\section{Green government procurement}

- None.

Financial and direct trade measures (subsidies, carbon pricing, taxation, R\&D etc.)

- None.

\section{International cooperation (climate finance, technology transfer, international mechanisms etc.)}

- Mongolia will seek international funding, capacity building and technology supports to complement its domestic resource allocations and efforts. Mongolia will articulate its specific needs, and communicate the potential supporting role of the international community. As a preliminary indication, some specific measures that will be important to reach the proposed targets, with estimated investment needs of 3.5 billion USD.

- Mongolia is interested in opportunities to access international climate funds namely the Green Climate Fund and in participation with crediting mechanisms to implement these measures. 


\section{GHG and non-GHG target:}

- Montenegro's contribution to the international effort to avoid dangerous climate change is expressed in $30 \%$ emission reduction by 2030 compared to the 1990 base year. The emission level of greenhouse gases for Montenegro from sectors covered by INDC was 5239 kilotons in 1990 and Montenegro pledges to reduce it at least by 1572 kilotons, to the level below or at 3667 kilotons. The reduction is to be achieved by general increase of energy efficiency, improvement of industrial technologies, increase of the share of renewables and modernization in the power sector.

\section{Measures related to the energy sector}

- None, but the INDC explicitly covers the energy sector.

\section{Green industrial policies}

- None, but the INDC explicitly covers the industrial processes and product use sectors.

\section{Green government procurement}

- None.

Financial and direct trade measures (subsidies, carbon pricing, taxation, R\&D etc.)

- Montenegro intends to sell carbon credits during the period to contribute towards achieving its emission reduction objectives as assistance to cost-effective implementation of the low emission development pathway.

International cooperation (climate finance, technology transfer, international mechanisms etc.)

- Montenegro foresees that for the utilization of international market mechanism is conditional on having effective accounting rules developed under the UNFCCC to ensure the environmental integrity of the mechanisms. 


\section{GHG and non-GHG target:}

- Unconditional Target: Morocco commits to a $17 \%$ reduction in GHG emissions by 2030 compared to a BAU scenario, with $4 \%$ coming from AFOLU actions. Without AFOLU actions, the reduction target is $13 \%$.

- Conditional Target: An additional reduction of $25 \%$ achievable under certain conditions, which would bring the total GHG reduction to $42 \%$ below BAU emission levels by 2030, including AFOLU actions. Without AFOLU actions, the additional reduction would be $21 \%$.

\section{Measures related to the energy sector}

- Provision of $52 \%$ of the installed electrical power from renewable sources, of which $20 \%$ is from solar energy, 20\% is from wind energy and $12 \%$ is from hydraulic energy by 2030 .

- Installation by 2030 of an additional capacity of 3,900 MW of combined-cycle technology running on imported natural gas.

- Substantial increase in the use of natural gas, through infrastructure projects allowing liquefied natural gas imports.

\section{Green industrial policies}

- Reduction of energy consumption in buildings, industry and transport by $12 \%$ by 2020 and 15 $\%$ by 2030 . The breakdown of expected energy savings per sector is $48 \%$ for industry, $23 \%$ for transport, $19 \%$ for residential and $10 \%$ for services.

- Achievement of $15 \%$ energy savings by 2030 , compared to current trends.

- Supply of imported and regazified natural gas by pipelines to major industries.

\section{Green government procurement}

- None.

Financial and direct trade measures (subsidies, carbon pricing, taxation, R\&D etc.)

- Substantial reduction of public fossil fuel subsidies, building on reforms already undertaken.

- Reduction of public subsidies to electricity and different petroleum products, such as industrial fuels and gasoline, a move that creates a more attractive environment for investments in renewable energy and the rationing of energy consumption.

\section{International cooperation (climate finance, technology transfer, international mechanisms etc.)}

- Meeting the overall target of $42 \%$ requires an investment estimated at USD 50 billion between 2010 and 2030. Meeting the conditional component of the target, for which costs are estimated to reach USD 24 billion, is conditional upon access to new sources of finance and to additional support, compared to that received over the past years.

- Morocco considers the establishment of international market-based mechanisms of primary importance, in order to promote cooperation between parties with respect to their mitigation contributions, as per Article 6 of the Paris Agreement. The mechanisms are vital in reducing total costs for achieving the temperature target outlined in Article 2 of the Paris Agreement. 


\section{GHG and non-GHG target:}

- Based on the policy actions and programmes outlined above, the country estimates, on a preliminary basis, the total reduction of about 76,5 MtCO2eq in the period from 2020 to 2030, with 23,0 MtCO2eq by 2024 and 53,4 MtCO2eq from 2025 to 2030. These reductions are estimates with a significant level of uncertainty and will be updated with the results from the BUR to be available by early 2018.

- The implementation of any proposed reduction is conditional on the provision of financial, technological and capacity building from the international community.

\section{Measures related to the energy sector}

- New and Renewable Energy Development Strategy (2011 to 2025).

- Conservation and Sustainable Use of the Energy from Biomass Energy Strategy (2014 to 2025).

- Master Plan for Natural Gas (2014 to 2030).

\section{Green industrial policies}

- None.

\section{Green government procurement}

- None.

Financial and direct trade measures (subsidies, carbon pricing, taxation, R\&D etc.)

- Renewable Energy Feed-in Tariff Regulation (REFIT).

International cooperation (climate finance, technology transfer, international mechanisms etc.)

- Mozambique is willing to participate in the market mechanisms to be established which would allow access to clean technologies in order to mitigate the emissions arising from exploiting, managing and using the natural capital that is available.

- The implementation of any proposed reduction is conditional on the provision of financial, technological and capacity building from the international community. 
GHG and non-GHG target:

- None.

\section{Measures related to the energy sector}

- Increase in the share of hydroelectric generation within limits of technical Hydroelectric potential. Indicative goal $-9.4 \mathrm{GW}$ by 2030

- Increase in the access to clean sources of electricity amongst communities and households currently without access to an electric power grid system.

\section{Green industrial policies}

- Improvements in energy efficiency within the Myanmar industry

- Focus on the implementation of energy management systems compatible with international standards.

- Energy optimization.

\section{Green government procurement}

- None.

Financial and direct trade measures (subsidies, carbon pricing, taxation, R\&D etc.)

- None.

International cooperation (climate finance, technology transfer, international mechanisms etc.)

- As an LDC, Myanmar requires further capacity-building along with access to technological and financial support from the international community to implement the INDC. In order to realise the intended mitigation contribution set out above and meet the nation's needs with respect to adaptation, Myanmar requires a significant amount of international support. The success of the mitigation and adaptation activities in Myanmar is wholly dependent on receiving sufficient technology-transfer, capacity-building and financial support from developed and more experienced countries, international agencies, donors, and the wider international community. 


\section{GHG and non-GHG target:}

- Namibia aims at a reduction of about $89 \%$ of its GHG emissions at the 2030 time horizon compared to the BAU scenario. The projected GHG emissions reduction in 2030 is of the order of $20000 \mathrm{Gg}$ CO2-eq inclusive of sequestration in the AFOLU sector and compared to the BAU scenario.

\section{Measures related to the energy sector}

- Increase in the share of renewable energy (hydro, solar, wind and biomass) in electricity production from 33\% in 2010 to about $70 \%$ in 2030.

- Commissioned hydro generation plant of Ruacana.

\section{Green industrial policies}

- Partial replacement of clinker in cement production. Replacing some $20 \%$ of the clinker will abate emissions by about $35 \mathrm{Gg}$ CO2-eq.

- Implementation of an energy efficiency programme to reduce consumption by about $10 \%$ in 2030 and other demand-side management measures.

\section{Green government procurement}

- None.

Financial and direct trade measures (subsidies, carbon pricing, taxation, R\&D etc.)

- Investments made through the Solar Revolving Fund.

International cooperation (climate finance, technology transfer, international mechanisms etc.)

- The cost of implementation of the INDC components of Namibia will require about US\$33 billion at 2015 prices.

- Namibia will need the support of the international community to overcome existing barriers, for the appropriation of technologies for both mitigation and adaptation, a sustained capacity building programme in the prioritized areas, technical support and funding to the tune of some 33 billion US\$.

- Namibia does not rule out the use of international market-based mechanisms to achieve its 2030 target in accordance with agreed accounting rules. 


\section{GHG and non-GHG target:}

- Time Frame 2020-2030

- Conditional Reduction based on identified mitigation actions

- To replace a substantial part of electricity generation with the existing diesel operated plants with a large scale grid connected solar photovoltaic (PV) system with an estimated cost of 42 million US\$ which would assist in reducing the emissions from fossil fuels.

- Concurrent to the above there needs to be put in place extensive demand side energy management improvements with an estimated cost of 8 million US\$ which will complement the PV installation. The demand management improvements are expected to reduce emissions by bringing down diesel consumption further.

- Unconditional Reduction

- The unconditional contribution includes a secured funding of US\$5 million for implementation of a 0.6 MW solar PV system, which is expected to assist in unconditional reduction of $\mathrm{CO} 2$ emissions marginally. This initiative will be used as a model project for the larger Solar PV plant and in addition assist in terms of technology transfer and institutional learning.

\section{Measures related to the energy sector}

- Replacement of a substantial part of the existing diesel generation with a large-scale grid connected solar photovoltaic (PV) system, which would assist in reducing the emissions from fossil fuels.

- Reduction of fossil fuel imports by using indigenous renewable energy and implementing energy efficiency measures.

\section{Green industrial policies}

- Extensive demand side energy management improvements, which will complement the PV installation.

\section{Green government procurement}

- None.

Financial and direct trade measures (subsidies, carbon pricing, taxation, R\&D etc.)

- None.

\section{International cooperation (climate finance, technology transfer, international mechanisms etc.)}

- The cost of these mitigation measures is likely to be around US\$50 million (USD 42 million for Solar PV and USD 8 million for demand side energy efficiency measures) with some uncertainty depending on the storage of energy either as electrical ( battery) or thermal (chilled water) to account for the high night time electrical load on the island. 


\section{GHG and non-GHG target:}

- Nepal has initiated several activities to reduce climate hazards and build resilience, help climate vulnerable communities cope with climate change impacts, and reduce impacts of climate change on its people, property and natural resources.

\section{Measures related to the energy sector}

- Nepal has a policy for maximum utilization of hydropower potential to meet its domestic demand of electricity by mitigating adverse environmental impacts.

- By 2020, Nepal intends to expand its energy mix focusing on renewable by $20 \%$ and diversifying its energy consumption pattern to more industrial and commercial sectors.

- Nepal is in the process of finalizing its Low Carbon Economic Development Strategy (LCEDS) to further promote the use of renewable energy and look into the cross-sectoral approaches of the economy where GHGs emissions can be minimized.

\section{Green industrial policies}

- Control of industrial pollution through effective regulations.

\section{Green government procurement}

- None.

\section{Financial and direct trade measures (subsidies, carbon pricing, taxation, R\&D etc.)}

- Policy to accelerate renewable energy services, and increase access to the Renewable Energy technologies with subsidy provisions.

- The National Rural Renewable Energy Programme (NRREP), under implementation, provides a framework for the local communities across the country to have access to not only energy but also energy efficient technologies through various subsidy programmes.

- The Subsidy Delivery Mechanism for renewable energy has been adopted since 2006 to ensure disbursement of subsidy in a cost effective and easy access manner in rural areas. Recently, the Government of Nepal has launched an initiative to promote solar energy, renewable energy technologies and energy-efficient technology in urban areas.

- Financial measures related to environmental goods and services

o The Environment-friendly Vehicle and Transport Policy (2014) aims, inter alia, to reduce emission from transport sector, increase the share of electric vehicle up to $20 \%$ by 2020 , promote the transformation of other regular vehicle to electric vehicle, and provide subsidy scheme for the promotion of electric and non-motorized vehicles.

\section{International cooperation (climate finance, technology transfer, international mechanisms etc.)}

- Given its current economic situation, Nepal will need technical and financial supports from development partners to provide relevant technologies, and build its capacity to be cleaner and greener while flourishing as one of the top tourism destinations in the world.

- Create an enabling environment to promote private sector investments and foreign direct investments in low carbon (energy efficiency and renewable energy) technologies. 
- Provide better price from carbon markets to ensure an equitable benefit sharing mechanisms and maximize benefits at the local level to help sustainable management of forests. 


\section{GHG and non-GHG target:}

- New Zealand commits to reduce GHG emissions to 30\% below 2005 levels by 2030 . This responsibility target corresponds to a reduction of $11 \%$ from 1990 levels.

- New Zealand has set a target of increasing renewable generation to $90 \%$ by 2025 .

\section{Measures related to the energy sector}

- None, but the NDC explicitly covers the energy sector.

\section{Green industrial policies}

- None, but the NDC explicitly covers industrial processes and product use sector.

\section{Green government procurement}

- None.

Financial and direct trade measures (subsidies, carbon pricing, taxation, R\&D etc.)

- None.

International cooperation (climate finance, technology transfer, international mechanisms etc.)

- Unrestricted access to global carbon markets that enable trading and use of a wide variety of units that meet reasonable standards and guidelines to ensure the environmental integrity of units/credits generated or purchased; guard against double-claiming/double-counting; and ensure transparency in accounting. 


\section{GHG and non-GHG target:}

- The Republic of Niger intends to make an unconditional reduction of 2.5\% (BaU 2020) and 3.5\% (2030). Niger also commits to make a conditional reduction of $25 \%$ (BaU 2020) and $34.6 \%$ (2030, or a reduction of $33,400 \mathrm{GgCO}_{2} \mathrm{e}$ ).

\section{Measures related to the energy sector}

- Electricity: Improvement of the rate of access to electricity.

- Promotion as domestic gas of biogas and biofuels at both the industrial and family level.

- Increase in capacity of $4 \mathrm{MW}$ in 2010, $250 \mathrm{MW}$ in 2030, $130 \mathrm{MW}$ of which comes from the Kandadji hydroelectric plant and $20^{\circ} \mathrm{MW}$ comes from wind energy (currently $0.035 \mathrm{MW}$ ).

- Doubling of the rate of energy mix to reach $30 \%$ energy mix in the primary and final energy balance.

- Conditional: exploitation of photovoltaic and thermal solar energy; exploitation of wind energy; construction of a nuclear power plant and a gas power plant; hydroelectricity; energy efficiency; use of biogas.

\section{Green industrial policies}

- Improvements in energy efficiency in industries and households, transportation and electricity distribution (reduction of losses from 12\% to less than 10\% in the 2020 horizon).

- Construction of frame free buildings.

- Development of standard files, Strategic Environmental and Social Assessments (SESA) and Environmental and Social Impact Assessments (ESIA), Measurement, Notification and Verification (MVN) procedures, project registration.

\section{Green government procurement}

- None.

Financial and direct trade measures (subsidies, carbon pricing, taxation, R\&D etc.)

- Enhancement of institutional, technical, financial and telecommunications capabilities and technology transfer.

\section{International cooperation (climate finance, technology transfer, international mechanisms etc.)}

- Niger supports the mechanisms of the international CO2 market, such as the Clean Development Mechanisms (CDM), but revised to facilitate the access of National Development Programmes (NDP) to this financing. For this purpose, it hopes to see a high price for $\mathrm{CO} 2$ (US $\$ 50 / t$ ) that will permit it to reach the global objective of $2^{\circ} \mathrm{C}$.

- Attaining the objectives of Niger's INDC requires a total investment estimated at US \$8.667 billion, US $\$ 7.5$ billion of which (87\% of the total) is dependent on access to new sources of financing (the Green Climate Fund and other climate financing mechanisms). The unconditional financing coming from the government's own resources and public development aid is estimated at US $\$ 1.167$ billion, or $13 \%$ of the total cost.

- The sustainable development objectives to which the INDC contributes cannot be realised without the transfer of appropriate technologies and the financing and building of 
competencies, while taking into account the national economic and social development priorities defined for the various strategic frameworks. 


\section{GHG and non-GHG target:}

- Nigeria will make an unconditional contribution of $20 \%$ below BAU that is consistent with the current development trends and government policy priorities. They include improving energy efficiency by $20 \%, 13 \mathrm{GW}$ of renewable electricity provided to rural communities currently off-grid, and ending gas flaring. Nigeria is also committed to reduce emissions $45 \%$ below BAU conditional on international support.

\section{Measures related to the energy sector}

- Work towards off-grid solar PV of 13GW (13,000MW).

- Efficient gas generators.

- Work towards ending gas flaring by 2030.

\section{Green industrial policies}

- Benchmarks against international best practice for industrial energy usage.

- $2 \%$ per year energy efficiency ( $30 \%$ by 2030$)$

- Inclusion of increased protective margins in construction and placement of energy infrastructure (i.e. higher standards and specifications).

\section{Green government procurement}

- None.

Financial and direct trade measures (subsidies, carbon pricing, taxation, R\&D etc.)

- Encouragement of informal savings and insurance schemes, and arrange for the availability of medium term credit (especially for industries in crisis).

- Reform of petrol/diesel subsidies

- Removal of consumer and producer subsidies for fossil fuels.

\section{International cooperation (climate finance, technology transfer, international mechanisms etc.)}

- Nigeria welcomes support for mitigation policies and measures in the form of direct investments and loans. Finance and investment can come from both public and private sources, including the Green Climate Fund and international financial institutions, such as the World Bank, IFC and AFDB. The international bilateral sources should include reliable, new and additional ODA. Contingent on agreement in Paris, it may also include financing through carbon market mechanisms.

- International finance and investment, technology and capacity-building will be needed to achieve the ambitious intended contribution. 


\section{GHG and non-GHG target:}

- The Niue Strategic Energy Road Map (NiSERM) 2015-2025 outlines Niue's aspiration to meet $80 \%$ of its electricity needs from renewable energy sources by 2025 , which would in turn reduce the country's high reliance on imported fossil fuel. Part of this goal can be achieved through national resources and identified assistance.

\section{Measures related to the energy sector}

- Niue will achieve a 38\% share of renewable energy of total electricity generation by 2020 (unconditional).

- Niue could increase its contribution to an $80 \%$ share of renewable energy of total electricity generation, or to even higher levels, by 2025 (conditional).

- Strengthening of Niue's capacity to adapt renewable energy technologies, improve energy efficiency and energy security.

- Reduction in dependency on fossil fuels, more sustainable, cleaner energy including additional solar PV, wind and assessing biofuel, biogas potentials.

\section{Green industrial policies}

- None.

\section{Green government procurement}

- None.

Financial and direct trade measures (subsidies, carbon pricing, taxation, R\&D etc.)

- Measures to attract funding for energy sector development.

\section{International cooperation (climate finance, technology transfer, international mechanisms etc.)}

- Achieving high levels of electricity from renewables (from around $2 \%$ today) is very ambitious and will need considerable contributions of financial and capacity support from our partners.

- Niue's economy is heavily dependent on support from New Zealand, which has a statutory obligation to provide economic and administrative assistance to Niue. Aid accounts for $70 \%$ of Niue's GDP, which is NZ $\$ 10,000$ per capita. Other sources of financial resources include taxation, government trading activities, sovereign assets and additional support from development partners. 


\section{GHG and non-GHG target:}

- Norway is committed to a target of an at least $40 \%$ reduction of greenhouse gas emissions by 2030 compared to 1990 levels. Norway intends to fulfil this commitment through a collective delivery with the EU and its Member States. In the event that there is no agreement on a collective delivery with the EU, Norway will fulfil the commitment individually. The ambition level will remain the same in this event. According to the broad political agreement in 2012 on climate change, the aim is that Norway will be carbon-neutral in 2050. This means that Norway will commit to achieving emission reductions abroad equivalent to Norwegian emissions in 2030.

\section{Measures related to the energy sector}

- None, but the NDC explicitly covers the energy sector.

\section{Green industrial policies}

- Low emissions technology in industry.

\section{Green government procurement}

- None.

Financial and direct trade measures (subsidies, carbon pricing, taxation, R\&D etc.)

- None.

International cooperation (climate finance, technology transfer, international mechanisms etc.)

- Norway will use market-based mechanisms under the UNFCCC. Strict criteria will be applied to ensure that such credits represent real and verifiable emission reductions and that double counting is avoided. 


\section{GHG and non-GHG target:}

- Oman will control its expected GHG emissions growth by $2 \%$ to be $88714 \mathrm{Gg}$ during the period from 2020-2030.

\section{Measures related to the energy sector}

- Increase in the share of renewable energy.

- Development of new legislation on climate change which will support the adoption of low carbon and energy efficiency technologies.

\section{Green industrial policies}

- Reduction in gas flaring from oil industries.

- Reduction of HCFC use in foam and refrigeration sector.

- Increase in energy efficiency projects among industries.

\section{Green government procurement}

- None.

Financial and direct trade measures (subsidies, carbon pricing, taxation, R\&D etc.)

- None.

International cooperation (climate finance, technology transfer, international mechanisms etc.)

- Fund, capacity building and transfer of technology from the UNFCCC will be required by the Sultanate of Oman to make further efforts in the following areas: sustainable building, development of renewable energy, law carbon technologies among the industries, water sector, health sector 


\section{GHG and non-GHG target:}

- Pakistan is committed to reduce its emissions after reaching peak levels to the extent possible subject to affordability, provision of international climate finance, transfer of technology and capacity building. As such Pakistan will only be able to make specific commitments once reliable data on our peak emission levels is available.

\section{Measures related to the energy sector}

- Increase in grid efficiency.

- Improvement in the efficiency of planned coal-based power generation.

- Large-scale and distributed grid-connected solar, wind and hydroelectricity.

\section{Green industrial policies}

- More efficient irrigation motors and pumps.

- Promotion of Energy Standards and Labeling (ESL) for manufacturers and importers, and promotion for consumers.

\section{Green government procurement}

- Upgrading and modernization of rail services

- Upgrading and development of efficient public transport systems.

Financial and direct trade measures (subsidies, carbon pricing, taxation, R\&D etc.)

- Provision of incentives for efficient vehicle operations.

International cooperation (climate finance, technology transfer, international mechanisms etc.)

- Wse of Clean Development Mechanism (CDM) and other market mechanisms to support climate change activities.

- The Ministry is actively reviewing policy considerations for further integration of market mechanisms in responding to emerging threats in the context of Article 6 of the Paris Agreement. 


\section{GHG and non-GHG target:}

- Palau commits to an absolute energy sector emissions reduction target, with additional reductions coming from the waste and transport sectors. Indicative targets: 22\% - energy sector emissions reductions below 2005 levels by 2025; 45\% renewable energy target by 2025 and 35\% energy efficiency target by 2025 .

\section{Measures related to the energy sector}

- Palau is working to increase the share of renewables in its energy mix and to increase energy efficiency initiatives.

\section{Green industrial policies}

- There is a pending national legislation that would mandate the use and commercial sale of four stroke outboard motor engines only to reduce emissions.

- A project investigation to convert waste cooking oil to biofuel for diesel vehicles, beginning with public school buses and a potential public bus route.

- Institution of a Tropical EE Building Code.

- Adoption of the Energy Star Appliance Standard.

- Implementation of an Energy Labeling Scheme.

- Home Energy Efficiency Program.

\section{Green government procurement}

- Government building retrofits.

Financial and direct trade measures (subsidies, carbon pricing, taxation, R\&D etc.)

- Increase the Energy Retrofit Program.

- Prepaid metering at Palau Public Utilities Corporation.

- Significantly expand Cool Roof Program.

- Financial measures related to environmental goods and services

$\circ$ Pilot loan subsidy for solar roof panels.

International cooperation (climate finance, technology transfer, international mechanisms etc.)

- Many of these renewable energy and energy efficiency initiatives will depend on the availability of partnership finance and technology support. 
GHG and non-GHG target:

- National efforts of the Republic of Panama will increase in the energy sector to achieve a $30 \%$ level of installed cappacity capacity from non-conventional renewable sources such as wind and solar by 2050 (15\% by 2030); in the UT-CUTS sector, assistance of the Green Climate Fund through a payment scheme for performance and other financial mechanisms, will allow increased carbon absorption capacity by $10 \%$ compared to baseline by 2050 ; and if the country receives international support for means of implementation, absorption capacity may be increased up to $80 \%$ compared to baseline.

\section{Measures related to the energy sector}

- Use of fuels with lower carbon content.

- Promotion of increased investment in renewable sources such as solar, wind and biomass (relying on Law 8 of 2015 and the National Energy Plan 2015-2050, mandating the lines of action for the decarbonization of the electricity matrix).

- Various sites that meet the necessary conditions for the installation of wind turbines or solar panel systems and their optimal performance have been identified. By January 2016, there are, according to the Public Services Authority (ASEP), licenses for the final installation of $1,184.1$ megawatts (MW) of renewable energies such as solar and wind power, equivalent to $41.8 \%$ of installed capacity in 2014.

- Provisional licenses for the construction of projects that will generate an installed capacity of 2083.92 MW through other types of renewable energy sources.

- Promotion of the use of new technologies for improved efficiency, generation, storage, transmission and distribution of energy.

Review and unification of the existing regulatory framework and establishment of financial mechanism to facilitate investment in other types of renewable energy sources by public and private actors.

\section{Green industrial policies}

- Modification and creation of new regulatory frameworks to promote energy efficiency.

\section{Green government procurement}

- None.

Financial and direct trade measures (subsidies, carbon pricing, taxation, R\&D etc.)

- Law 37 of 2013, which establishes an incentive regime for promoting the construction, operation and maintenance of solar power plants and / or solar installations.

- Law 44 of 2011 and Law 18 of 2013, establishing a system of incentives to promote the construction and operation of wind farms for the provision of public electricity services.

- Law 45 of 2004, which establishes a system of incentives for the promotion of hydroelectric generation systems and other new, renewable and clean sources and other provisions.

- Panama will contemplate the implementation of a carbon market.

\section{International cooperation (climate finance, technology transfer, international mechanisms etc.)}

- Panama will continue to participate in international emissions trading. 
- The country will take voluntary measures in international sea and air sectors, within the framework of the International Maritime Organization (IMO) and the International Civil Aviation Organization (ICAO), through market-based measures.

- Panama's commitment in the fight against climate change was also ramped up through a donation of USD 1 million to the Green Climate Fund (GCF). Panama hopes thereby contribute to the implementation of policies and mitigation and adaptation projects around the world. 
GHG and non-GHG target:

- Papua New Guinea commits to reach a target of $100 \%$ renewable energy by 2030 , contingent on funding being made available.

\section{Measures related to the energy sector}

- Papua New Guinea aims to transfer a proportion of its electricity generation to renewables.

- Relatively high installed capacity of hydro of around $200 \mathrm{MW}$ presents itself as a large scale storage facility for intermittent renewable inputs to be fed to the main Port Moresby grid.

- Geothermal potential of $56 \mathrm{MW}$ installed (2010) and $22 \mathrm{TWh} /$ annum possible, albeit mostly in remote areas.

- Final balance to achieve close to $100 \%$ renewables is to be filled using solar PV.

- National target to become carbon free by 2030 in the electricity sector. Many options in terms of PV, geothermal, biomass fueled plants and additional hydro could be investigated which will make the country close to $100 \%$ renewable energy in the power sector.

- Longer-term increases in energy consumption will be restrained and ameliorated by extensive energy efficiency options.

\section{Green industrial policies}

- None.

\section{Green government procurement}

- Improvement of public transport by introducing energy efficient buses in the main urban centres.

\section{Financial and direct trade measures (subsidies, carbon pricing, taxation, R\&D etc.)}

- Private finance could be made available especially for the mining and oil and gas sectors. Energy efficiency initiatives could be encouraged by policy decisions.

International cooperation (climate finance, technology transfer, international mechanisms etc.)

- External funding and assistance will be necessary for the replacement of fossil fueled electricity generation with renewable energy sources; energy efficiency and conservation, capacity building and technology transfer for emissions data collection and tracking mitigation progress. 
GHG and non-GHG target:

- Paraguay plans to achieve a reduction in the amount of $429 \mathrm{MtCO} e q$ during the implementation of this action plan, and from 2030 to avoid emissions by a total of 83 MtCO2eq annually, established according to the calculations of development projected in existing studies.

- $20 \%$ reductions based on the behavior of projected emissions by 2030 .

- Unilateral Target: $10 \%$ reduction of projected emissions by 2030.

- Conditional Target: 10\% reduction of projected emissions by 2030 .

\section{Measures related to the energy sector}

- Increase in the consumption of renewable energy by $60 \%$.

- Reduction by $20 \%$ of the consumption of fossil fuel.

- Incorporation of technologies for the exploitation of new sources of sustainable energy (including solar, wind, biomass).

\section{Green industrial policies}

- None.

\section{Green government procurement}

- None.

\section{Financial and direct trade measures (subsidies, carbon pricing, taxation, R\&D etc.)}

- Paraguay needs to promote the application of financial resources to implement plans, programs and projects for adaptation and mitigation to climate change in the following priority sectors: energy, clean industries, infrastructure and transport.

International cooperation (climate finance, technology transfer, international mechanisms etc.)

- The conditional targets will require international cooperation on finance, technology transfer, capacity building.

- Paraguay is promoting mechanisms to encourage technology transfer, to promote and facilitate research and applicable solutions to vulnerability and adaptation to the effects of climate change, including those that ensure poverty reduction, food sovereignty and security. 
GHG and non-GHG target:

- Peru envisages a reduction of emissions equivalent to $30 \%$ in relation to GHG emissions of the projected BAU in 2030. 20\% reduction will be implemented through domestic investment and expenses, from public and private resources (non-conditional proposal), and the remaining $10 \%$ is subject to the availability of international financing and the existence of favorable conditions.

Measures related to the energy sector

- None.

\section{Green industrial policies}

- None.

\section{Green government procurement}

- None.

Financial and direct trade measures (subsidies, carbon pricing, taxation, R\&D etc.)

- None

International cooperation (climate finance, technology transfer, international mechanisms etc.)

- Renewable energy and energy efficiency initiatives will depend on the availability of partnership finance and technology support.

- Peru is to sell emission reductions provided this is not an obstacle for the compliance with the national commitment. 


\section{GHG and non-GHG target:}

- The Republic of Philippines intends to undertake GHG (CO2e) emissions reduction of about $70 \%$ by 2030 relative to its BAU scenario of 2000-2030.

- Reduction of $\mathrm{CO} 2 \mathrm{e}$ emissions will come from energy, transport, waste, forestry and industry sectors. The mitigation contribution is conditioned on financial resources, including technology development and transfer, and capacity building, that will be made available to the Philippines.

\section{Measures related to the energy sector}

- None.

\section{Green industrial policies}

- None.

\section{Green government procurement}

- None.

Financial and direct trade measures (subsidies, carbon pricing, taxation, R\&D etc.)

- None.

\section{International cooperation (climate finance, technology transfer, international mechanisms etc.)}

- Technology transfers and innovations are needed to support adaptation and minimization of loss-and-damages as well as enhanced capacity for mitigation. Technical inputs and assistance are critical for certain sectors such as grid efficiency improvement, standard development for energy and waste efficiency, cost-effective renewable energy, alternative or high-efficiency technology for conventional power generation, among others.

- The mitigation contribution is conditioned on the availability of financial resources, including technology development and transfer, and capacity building, that will be made available to the Philippines. 
GHG and non-GHG target:

- None.

\section{Measures related to the energy sector}

- Efforts have been made into solar energy generation with a view to becoming a regional supplier of solar-generated electricity.

- Some national entities started considering solar and wind sources to generate electricity for small buildings aiming to open a new market, in the hope of strengthening the economic diversification.

- Utilization of clean energy and renewables.

\section{Green industrial policies}

- Reduction of dependence on hydrocarbon resources by promoting sustainable tourism strategies, as well as to protect the country's economy from market fluctuations that can significantly affect its economic growth.

\section{Green government procurement}

- None.

Financial and direct trade measures (subsidies, carbon pricing, taxation, R\&D etc.)

- Investment in research and development in various areas including sustainable energy, in line with its National Research Strategy. Many research activities are being carried out in various fields, improving the environment to adapt with climate change impacts, utilizing clean energy and renewables, reducing emissions to the atmosphere and developing technologies that convert emissions into useful products.

International cooperation (climate finance, technology transfer, international mechanisms etc.)

- None. 


\section{GHG and non-GHG target:}

- $\quad$ Limiting anthropogenic greenhouse gases in Russia to $70-75 \%$ of 1990 levels by the year 2030 might be long-term indicator, subject to the maximum possible account of absorbing capacity of forests. Economywide, in particular, as determined by decisions of the UNFCCC Conference of the Parties on reporting: energy, industrial processes and products use; agriculture; land use, land use change and forestry and waste.

\section{Measures related to the energy sector}

- None, but the INDC explicitly covers the energy sector.

\section{Green industrial policies}

- None, but the INDC explicitly covers the industrial processes and product use sector.

\section{Green government procurement}

- None.

Financial and direct trade measures (subsidies, carbon pricing, taxation, R\&D etc.)

- None.

International Cooperation (climate finance, technology transfer, international mechanisms etc.)

- The INDC indicator is to be achieved with no use of international market mechanisms. 
GHG and non-GHG target:

- None.

\section{Measures related to the energy sector}

- Rwanda aims to achieve Energy Security and a Low Carbon Energy Supply.

- Rwanda will increase the share of renewable energy in country power generation through construction of hydro, solar power plants and methane to electricity power plants hence shifting from using fossil fuels for its electricity needs.

- Rwanda will establish up to 100 solar PV mini-grids in rural communities, with total capacity of up to $9.4 \mathrm{MWp}$ and will establish rural productive zones using electricity for increasing the income generating potential of rural communities.

- Planning and implementation of measures aiming at reducing grid losses. These are expected to drop from $23 \%$ c to $7.8 \%$ by 2030 .

\section{Green industrial policies}

- Through the energy utility, Rwanda will establish dedicated energy efficiency and demand side management unit to oversee the design and implementation of relevant efficiency programs to clip electrical peak demand.

\section{Green government procurement}

- None.

Financial and direct trade measures (subsidies, carbon pricing, taxation, R\&D etc.)

- Targeted subsidies for retrofits.

\section{International Cooperation (climate finance, technology transfer, international mechanisms etc.)}

- Rwanda is committed to create a regional interconnectivity through construction of new transmission lines and sub-stations and will improve/upgrade existing ones. This will allow the import of electricity that would be otherwise generated from fossil fuel power plants (diesel or peat power plant). 


\section{GHG and non-GHG target:}

- The Federation of St. Kitts and Nevis proposes an emissions reduction target of $22 \%$ and $35 \%$ of the emissions projected in the BAU scenario for 2025 and 2030, respectively.

- As regards the reference point, $22 \%$ of the absolute GHG from the BAU in 2025 and $35 \%$ of the absolute GHG from the BAU in 2030. The timeframe to implement the INDC is from 2020-2030, mid-term review in 2025. Reduction in GHG emissions by focusing on electricity generation and the transport sector.

\section{Measures related to the energy sector}

- The policies and measures would increase the use of renewable energy sources by $50 \%$.

\section{Green industrial policies}

- None.

\section{Green government procurement}

- None.

Financial and direct trade measures (subsidies, carbon pricing, taxation, R\&D etc.)

- None.

International cooperation (climate finance, technology transfer, international mechanisms etc.)

- None. 
GHG and non-GHG target:

- Saint Lucia proposes that the conditional target measured against the BAU emissions projections of $16 \%$ reduction by 2025 (121 GgCO2eq) and 23\% reduction by 2030 (188 GgCO2eq). The three main sectors targeted by the INDC are energy, electricity generation and transport.

\section{Measures related to the energy sector}

- $35 \%$ renewable energy target by 2024 and $50 \%$ by 2030 based on a mix of geothermal, wind and solar energy sources.

- Improvements to Grid Distribution and Transmission Efficiency.

- A waste management strategy that includes the conversion of waste into energy.

- National Utility Regulatory Commission Bill (establishes an independent regulatory commission to oversee electricity production).

- Development of draft Geothermal Development Bill

\section{Green industrial policies}

- Introduction of efficient vehicles and improved as well as expanded public transit.

- Introduction of a new levy to control importation of used vehicles.

- Hydrochloroflurocarbon (HCFCs) Phase Out Management Plan as well as Draft Code for Refrigeration and Air Conditioning Technicians.

- Draft Revised Building Code (includes energy efficiency measures)

- National Energy Efficiency Labeling Standards (Air-Conditioning units, tubular and compact fluorescent lamps).

\section{Green government procurement}

- None.

Financial and direct trade measures (subsidies, carbon pricing, taxation, R\&D etc.)

- Escalating taxes on higher engine capacity vehicles.

- Implementation of national level market-based instruments, such as cap-and-trade emission trading schemes and offsetting.

- Incentives for Renewable Energy.

- Financial measures related to environmental goods and services

$\circ$ Reduction of excise tax and duty for importers of fuel-efficient vehicles and alternative energy vehicles.

International cooperation (climate finance, technology transfer, international mechanisms etc.)

- Saint Lucia will pursue a mix of international funding, private sector financing, and support from regional agencies and programmes and bilateral processes. 


\section{GHG and non-GHG target:}

- St. Vincent and the Grenadines intends to achieve an unconditional, economy-wide reduction in greenhouse gas (GHG) emissions of $22 \%$ compared to its BAU (BAU) scenario by 2025.

- The proposed contribution is economy-wide and is in comparison to all sectors and sources of emissions, the contribution is based upon key measures in the energy (including energy generation, energy efficiency and transport) sector.

\section{Measures related to the energy sector}

- Development of the country's proposed geothermal power plant (planned to be completed in 2018). The facility, when complete, will generate approximately $50 \%$ of the national annual electricity consumption needs.

- The national energy utility is renovating existing hydropower facilities to improve efficiency and generation capacity as well as enabling and encouraging the installation of small-scale photovoltaics (PV) in the private and public sectors.

\section{Green industrial policies}

- Planned measures in this sector include a new building code and an energy-labeling scheme for appliances.

\section{Green government procurement}

- Retrofitting of street lighting nationally.

\section{Financial and direct trade measures (subsidies, carbon pricing, taxation, R\&D etc.)}

- New policies to reduce the import duty paid on low emission vehicles are in the process of being introduced to encourage their use. It is estimated that this will result in avoided emissions of approximately $10 \%$ over the next 10 years.

International cooperation (climate finance, technology transfer, international mechanisms etc.)

- Significant potential for greater reductions (e.g. improved public transport) is achievable if international finance can be made available.

- Transport is the fastest growing source of emissions and reductions from this sector will be largely dependent on international financial support and technology transfer. 
GHG and non-GHG target:

- Samoa is committed to reducing its GHG emissions from the Electricity sub-sector through the adoption of a $100 \%$ Renewable energy target for electricity generation through to the year 2025 .

\section{Measures related to the energy sector}

- $100 \%$ renewable electricity generation by the year 2017 , which is supported by a combination of policy, level actions and development projects. 100\% contribution to be maintained through to 2025 in anticipation of the increasing electricity demand.

- Hydro Power - rehabilitation of 3.5 MW hydro power plants destroyed by Cyclone Evan in 2012 as well as additional small run-of-river schemes.

- Bioenergy - 12MW of various projects aimed at utilizing biomass, biogas or alternative bioenergy sources for electricity generation to be implemented by IPPs.

\section{Green industrial policies}

- Energy Efficiency - Projects aimed at controlling the importation of energy inefficient appliances such as product and labeling standards, retrofitting older and less efficient light bulbs with more efficient alternatives in the residential sector and other demand side management programs

\section{Green government procurement}

- None.

Financial and direct trade measures (subsidies, carbon pricing, taxation, R\&D etc.)

- Samoa currently uses no market mechanisms but is willing to pursue the potential of markets where possible.

\section{International cooperation (climate finance, technology transfer, international mechanisms etc.)}

- Economy-wide emissions reductions are conditional on Samoa receiving external financial assistance from the international community. Investment is needed to upgrade and maintain existing infrastructure, promote improvements in storage and grid, ensure the low emission pathway chosen by the electricity sub-sector is achieved. 


\section{GHG and non-GHG target:}

- The Republic of San Marino commits to reduce GHG emissions to 20\% below 2005 levels by 2030. The target sectors include energy, industrial processes and product use; agriculture; land-use, land-use change and forestry; waste.

\section{Measures related to the energy sector}

- None, but the INDC explicitly covers the energy sector.

\section{Green industrial policies}

- None, but the INDC explicitly covers the industrial processes and product use sector.

\section{Green government procurement}

- None.

Financial and direct trade measures (subsidies, carbon pricing, taxation, R\&D etc.)

- None.

- Financial measures related to environmental goods and services

- The Government of San Marino has promoted the development of solar energy, in particular solar PV, throughout forms of incentives, benefits and bonuses.

\section{International Cooperation (climate finance, technology transfer, international mechanisms etc.)}

- The Republic of San Marino intends to achieve its goals of reducing emissions exclusively through domestic measures. However, the use of international mechanisms based on the market is not excluded if domestic reductions will prove insufficient to achieve the targets set.

- San Marino supports the inclusion of international aviation and shipping on the basis of future internationally agreed rules applicable to all parties. 
GHG and non-GHG target:

- The STP would be able to contribute to the reduction of GHG by about $57 \mathrm{ktCO} e q$, which approximately corresponds to a 24\% national emission reduction by 2030 related to 2005 .

\section{Measures related to the energy sector}

- Isolated Mini Power Plant (1 MW); Hydro Power Plant connected to the main network (9 MW); Photovoltaic solar panels (12 MW); and Mini-hydro Power plant connected to the main grid (4 MW). Implementation of these four measures would mean an introduction of about $47 \%$ renewable energy in the national electricity system compared to the projected BAU electricity production, of which $34 \%$ is hydro and $13 \%$ solar (PV).

\section{Green industrial policies}

- None.

\section{Green government procurement}

- None.

Financial and direct trade measures (subsidies, carbon pricing, taxation, R\&D etc.)

- None.

International Cooperation (climate finance, technology transfer, international mechanisms etc.)

- A total investment of not less than US\$50 million in the form of external aid will be required between 2020 and 2030. According to the mitigation measures identified, the necessary technologies are: Hydropower Electricity Generation Systems; and Photovoltaic Electricity Generation Systems. Thus, STP requests technology support and capacity building.

- The contributions of STP with regard to mitigation are conditions by financial support, technological support and capacity-building that the country will receive from abroad.

- Sao Tome and Principe supports the use of market mechanisms including the results of mitigation pre-2020, such as the use of Emission Reduction Certificates (ERCs) generated by CDM projects and programs

- Sao Tome and Principe recognizes the experience gained from the implementation of the Clean Development Mechanism and want to be supported by market mechanisms with high environmental integrity, contributing to sustainable development and establishing strong incentive to harness the power of private sector. 
GHG and non-GHG target:

- The actions and plans outlined in this submission seek to achieve mitigation co-benefits ambitions of up to 130 million tons of CO2eq avoided by 2030 annually through contributions to economic diversification and adaptation.

\section{Measures related to the energy sector}

- Conversion of single cycle power plants to combined cycle power plants.

- Investment in and implementation of ambitious programs for renewable energy to increase its contribution to the energy mix. The scope will include solar PV, solar thermal, wind and geothermal energy and waste to energy systems.

- Carbon Capture and Utilization/Storage: Promote and encourage actions in this area. As part of its sustainability programme, the country plans to build the world's largest carbon capture and use plant. This initiative aims to capture and purify about 1,500 tons of CO2 a day for use in other petrochemical plants. Saudi Arabia will operate on pilot testing the viability of $\mathrm{CO} 2$ sequestration in oil reservoirs and any other useful applications. Forty million standard cubic feet a day of $\mathrm{CO} 2$ that will be captured, processed and injected into the Othmaniya oil reservoir.

- Encourage investments on exploring and producing natural gas to significantly increase its contribution to the national energy mix. The success on realizing the Mitigation co-benefit ambition in this area will depend on the success of exploring and developing natural gas.

- Conservation, recovery and reuse of hydrocarbon resources and minimization of flaring and fugitive emissions.

\section{Green industrial policies}

- Implementation of measures and initiatives that will promote, encourage energy efficiency. Strengthening of the Saudi Energy Efficiency Program and expansion of its focus.

- Introduction of efficiency standards in the building and transportation sectors as well as the implementation of energy efficiency measures, in various industrial establishments.

\section{Green government procurement}

- None.

Financial and direct trade measures (subsidies, carbon pricing, taxation, R\&D etc.)

- Fuel taxes, subsidies and incentives for all complementary sources of energy.

- Competitive procurement process for renewable energy.

\section{International Cooperation (climate finance, technology transfer, international mechanisms etc.)}

- The implementation of Saudi Arabia's INDC is not contingent on receiving international financial support, but the Kingdom of Saudi Arabia sees an important role for technology cooperation and transfer as well as capacity building for INDC implementation. 


\section{GHG and non-GHG target:}

- Under the unconditional scenario (INDC) emission reductions relative to baseline projections will be $3 \%, 4 \%$ and $5 \%$ in 2020, 2025 and 2030 respectively. Under the conditional scenario (INDC+), expected emission reductions will be $7 \%, 15 \%$ and $21 \%$ for the same years.

\section{Measures related to the energy sector}

- Unconditional options - EnR1 Program:

- Solar PV: plants with a combined total capacity of $160 \mathrm{MWp}$.

- Wind turbines: plants with a combined total capacity $150 \mathrm{MW}$.

- Hydroelectric: plants with a combined total capacity of 144 MW / 522 GWh.

○ Rural Electrification (PNUER).

- 392 villages electrified by solar mini-grid or hybrid electrified (diesel / solar).

- Conditionsal options - EnR2 Program:

- Wind turbines: central commissioning for a combined total capacity of $200 \mathrm{MW}$.

- Solar PV: central commissioning for a combined total capacity of $200 \mathrm{MWp}$.

- Biomass: central commissioning for a combined total capacity of $50 \mathrm{MW}$.

- Solar - CSP: central commissioning of a combined total capacity of $50 \mathrm{MW}$.

- Hydroelectric: Injection on the network of an additional 200 GWh in 2025.

- Replacement of the coal plant Jindal 320MW by two combined-cycle power plants using Liquefied Natural Gas (CCGT) 400 MW (2025: 200 MW and 2028: 200 MW)

- 5000 villages electrified by solar power (mini-grid) for universal access to electricity.

- Energy recovery of methane and methane (conditional).

- Waste recovery in Agriculture (biogas).

- Natural gas: replace $40 \%$ of coal dedicated to the self-production of electricity with natural gas (conditional).

\section{Green industrial policies}

- Substitution of clinker in cement manufacturing (conditional).

- Mandatory audits for large companies.

- Energy supply studies for new plants (75 studies / year).

\section{Green government procurement}

- Energy efficiency in the administration program (conditional).

- Energy efficiency in street lighting (replacing 75,000 streetlights).

Financial and direct trade measures (subsidies, carbon pricing, taxation, R\&D etc.)

- Environmental upgrade of enterprises through financial incentives.

International cooperation (climate finance, technology transfer, international mechanisms etc.) 
- The financing requirements of the conditional contribution amount to 5 billion US dollars. Funding for the conditional contribution is expected within the financial mechanisms that will accompany the Agreement.

- A need for technical assistance to address gaps and lack of expertise has been identified to support the implementation, operation and maintenance of sustainable technologies: Combined-Cycle Natural Gas Plants; CSP (TES + Desalination + NG); wind turbines and permanent magnet direct drive generators; Natural Gas logistics and infrastructure requirements; $\mathrm{co}$ / tri-generation system; system surveillance, measurement and monitoring.

- Senegal does not intend to fulfill its contribution by purchasing emission reductions from either existing or future market mechanisms. Nevertheless, Senegal will welcome any international mechanism on climate change seeking to protect the planet through compliance with standards that offer real, permanent, additional and verified results while avoiding double counting and which meet its sustainable development objectives.

- Senegal supports the continuation of the Clean Development Mechanism (CDM) established under the Kyoto Protocol and its continuation in a form to be defined in the new Agreement. 
GHG and non-GHG target:

- The Republic of Serbia aims to reduce the GHG emissions by $9.8 \%$ until 2030 compared to base-year 1990 emissions.

Measures related to the energy sector

- None.

Green industrial policies

- None.

Green government procurement

- None.

Financial and direct trade measures (subsidies, carbon pricing, taxation, R\&D etc.)

- None.

International Cooperation (climate finance, technology transfer, international mechanisms etc.)

- None. 


\section{GHG and non-GHG target:}

- Seychelles commits to absolute economy-wide reductions covering public electricity, land transport and solid waste management (LULUCF is excluded). The estimated quantified emission reduction is $122.5 \mathrm{ktCO} 2 \mathrm{e}$ in 2025 and $188 \mathrm{ktCO} 2 \mathrm{e}$ in 2030 relative to baseline emissions.

\section{Measures related to the energy sector}

- The Energy Policy which was proposed in 2010 has set a target of $15 \%$ of energy supply to be met from RE sources in 2030. The expected target in 2020 is $5 \%$. In the long-term, the Policy envisages that $100 \%$ of energy supply will be from renewable energy sources.

- Promotion of solar water heating target of $80 \%$ of needs in Households, and $80 \%$ in Services by 2035.

- Promotion of cogeneration (production of hot-water from waste heat from electricity generation in hotels, target to cover $20 \%$ of hot water needs by 2035).

- 15.8 MW of solar PV for meeting the energy demand of electric vehicles (capital expenditure, and operation and maintenance costs).

- $90 \mathrm{MW}$ of solar PV (capital expenditure, and operation and maintenance cost over lifetime of 20 years).

- Retrofitting the old landfill with landfill gas capture and flaring equipment.

\section{Green industrial policies}

- Keeping a high penetration of public transport, targeting fuel efficiency and biofuels in import regulation and moving towards electric vehicles and two-wheelers, have the potential to reduce oil imports for transport purposes by $15 \%$ to $30 \%$ (or perhaps more) by 2030 compared to the baseline.

- $30 \%$ of private vehicles will be electric by 2030 .

- Promotion of energy-efficient appliances: target of $10 \%$ energy savings in 2035.

- New Building Code for Household dwellings (features natural ventilation, roof insulation), target of $50 \%$ energy savings on fans and AC in households by 2035

- New Regulations on the use of air-conditioning, target of $20 \%$ energy savings in the service sector.

\section{Green government procurement}

- None.

Financial and direct trade measures (subsidies, carbon pricing, taxation, R\&D etc.)

- None.

International cooperation (climate finance, technology transfer, international mechanisms etc.)

- The cost of achieving the reduction objective (2030) has been estimated to be at least $\$ 309$ million. The cost will be partly conditional on international climate financing including through the Green Climate Fund. 


\section{GHG and non-GHG target:}

- Sierra Leone could not commit to an absolute GHG outcome. The INDC intends to maintain the emission levels of Sierra Leone relatively Low (close to the world average of $7.58 \mathrm{MtCO} 2 \mathrm{e}$ ) by 2035 or neutral by 2050 by reducing its carbon footprint and by following green growth pathways in all economic sectors.

- Intensity based reduction target by 25 to $35 \%$, by 2050 in phases (2020-2030, 2030-2050) compared to 1990 to hold per capita emissions in Sierra Leone's average world level in the longer term.

\section{Measures related to the energy sector}

- Enhanced management and expansion of the energy mix through uptake of renewable energy sources (Solar, Wind, Hydro, Biomass) particularly in the rural areas.

- Sierra Leone has over 20 hydro potential sites of which the Bumbuna Dam is the only one that has been tapped. This dam, which has been completed, has a capacity of $50 \mathrm{MW}$. If five of these hydro potential including Bumbuna are utilized, it may result in almost zero emission for the electricity sector.

\section{Green industrial policies}

- Diversification of economic growth through strengthened transport sub-sector and infrastructures.

\section{Green government procurement}

- None.

Financial and direct trade measures (subsidies, carbon pricing, taxation, R\&D etc.)

- Design of a Sierra Leone Climate Fund (SLCF), with resources mobilized domestically, internationally (bilateral and multilateral), and from private and market mechanisms.

- Implementation of specific mitigation actions like advancing a feed-in tariff for renewable energy technologies, phasing out fossil fuel subsidies, or converting to no-tillage agricultural practices.

\section{International Cooperation (climate finance, technology transfer, international mechanisms etc.)}

- The INDC target will only be achieved by Sierra Leone with the availability of international support that will come in the form of finance, investment, technology development and transfer, and capacity building. This would require substantial donor support estimated to about $\$ 900$ million.

- Design of a stand-alone dedicated Sierra Leone Climate Fund (SLCF), with resources mobilized domestically, internationally (bilateral and multilateral), and from private and market mechanisms.

- Sierra Leone supports the inclusion of the international Carbon Markets such as CDM in a post 2020 agreement on climate change and proposes that such instrument be tied to an appropriate MRV system to be used to help finance low carbon and climate resilient infrastructure investments.

- Sierra Leone considers that certain low emission development options mentioned in the INDC 
or additional actions could be entirely or partially be funded by the transfer of international carbon assets while taking into account environmental integrity and transparency. Sierra Leone intends to include its carbon assets in accounting for its emission reduction commitment. 


\section{GHG and non-GHG target:}

- Singapore aims to reduce its emissions intensity by $36 \%$ from 2005 levels by 2030 , and stabilize its emissions with the aim of peaking around 2030.

\section{Measures related to the energy sector}

- The government is significantly increasing the deployment of solar PV systems through enabling environment which facilitates system integration of intermittent sources to ensure grid stability and security and address non-market barriers to entry without subsidizing the consumption of any form of energy.

\section{Green industrial policies}

- Singapore's more than $60 \%$ of manufactured goods are proposed for exports, thus energy efficiency is going to be incentivized.

- Strong pollution control laws to encourage industries to switch to cleaner fuel sources such as natural gas.

\section{Green government procurement}

- None.

Financial and direct trade measures (subsidies, carbon pricing, taxation, R\&D etc.)

- Singapore prices energy at market cost, without any subsidy, to reflect resource scarcity and promote judicious usage.

- Government facilitates the adoption of energy efficient technologies through grants and other policy tools to overcome high upfront capital investments and other non-market barriers.

- Continue to invest significantly in research and development to explore new innovations in low carbon technologies.

- Financial measures related to environmental goods and services

$\circ$ Singapore supports continued investment in research, development and demonstration (RD\&D) to reduce the cost of solar PV modules and improve their efficiency.

International cooperation (climate finance, technology transfer, international mechanisms etc.)

- None. 


\section{GHG and non-GHG target:}

- Solomon Islands commits to reduce emissions by $12 \%$ below 2015 level by 2025 and 30\% below 2015 level by 2030 compared to a BaU projections, on an understanding that a global agreement addresses international assistance to access financial and technical resources.

- The target sectors include: Energy sector: Power (395), Transport (61\%); Renewable and EE and Land use, Land use Change and Forestry.

\section{Measures related to the energy sector}

- Solomon Islands aims to develop the following mitigation options: flu hydropower, solar farm, tina hydropower, solar homes, mini hydropower and energy usage.

- Following is a brief summary of the activities proposed for off-grid electricity production, with estimates of financial resources required: Solomon Islands aim to develop 6 hydropower plants like Luembalele $(\$ 750,000)$, Huro River $(\$ 550,000)$, Mase River $(4,000,000)$, Sorave River $(600,000)$, Rori $(\$ 750,000)$ and Vila River $(\$ 4,000)$. It aims to develop 7 solar power plants: Taro $(\$ 3,00,000)$, Seghe $(\$ 3,00,000)$, Aflo $(\$ 3,00,000)$, Selwyn College $(\$ 150,000)$, Kakabona Solar Farm (\$4,000,000), Solar Farm Honaria $(5,000,000)$ and Savo Geothermal $(\$ 150,000,000)$.

\section{Green industrial policies}

- None.

\section{Green government procurement}

- None.

Financial and direct trade measures (subsidies, carbon pricing, taxation, R\&D etc.)

- Setting aside the value added tax charged for fuel; charging carbon levies; and charging fees for climate change research undertaken in the country. Such fees and charges will be used to establish and finance a national climate change trust fund for priority climate change measures.

\section{International cooperation (climate finance, technology transfer, international mechanisms etc.)}

- With international assistance the country can contribute a further $27 \%$ reduction in $\mathrm{GHG}$ emissions by 2025; and $45 \%$ reduction in GHG emissions by 2030 , compared to a $\mathrm{BaU}$ projection. 


\section{GHG and non-GHG target:}

- None.

\section{Measures related to the energy sector}

- Rehabilitation of Fanoole Dam power plant to establish the generation of hydropower of 4.6 MW. The plant would provide electricity for communities in Middle and Lower Juba Valley and the expected emission reductions from replacing this electricity by clean hydropower is estimated to be around 23,000 tCO2/year.

- The Benadir Electric Company (BECO) is expected to mount solar equipment to generate 5 MW.

- Solar equipment for other $10 \mathrm{MW}$ for two sites is expected to arrive in Mogadishu in the near future.

- Numerous, new standby generators (diesel) that support power generation will also arrive with the solar equipment.

- Plan for Benadir Electric Company (BECO) to add three solar sub-stations into its Mogadishu grid.

- The government in partnership with the private sector will formulate policies to extend solar energy technology to rural towns and communities.

\section{Green industrial policies}

- None.

\section{Green government procurement}

- None.

Financial and direct trade measures (subsidies, carbon pricing, taxation, R\&D etc.)

- None.

International cooperation (climate finance, technology transfer, international mechanisms etc.)

- Competitive bidding and engagement of foreign investors for the construction and management of the Fanoole Dam. The total project costs in summary will be US\$28.175 million. 
GHG and non-GHG target:

- South Africa's emissions by 2025-2030 will be in the range of 398 and 614 Mt CO2-eq

- South Africa's effort will allow its greenhouse gas emissions to peak between 2020 and 2025, plateau for approximately a decade and decline in absolute terms thereafter.

\section{Measures related to the energy sector}

- South Africa is investing heavily in transforming in energy sector to replace an inefficient fleet of ageing coal-fired power plants with clean and high efficiency technology going forward. To date, it has facilitated substantial investment in renewable energy and two new high-efficiency coal-fired power stations are nearing completion as part of the ageing plant replacement programme.

- Renewable Energy Independent Power Producer Procurement Programme (RE14P) has approved 79 renewable energy IPP projects, total 5,243 MW, with private investment totaling ZAR 192 billion (approx. US\$16 billion). Another $6300 \mathrm{MW}$ are under consideration.

- Possibility of promoting solar water heaters; solar PV; wind power; carbon capture and sequestration; and advanced bio-energy.

\section{Green industrial policies}

- Desired emission reduction outcomes (DEROs) for sectors, company-level carbon budgets, as well as regulatory standards and controls for specifically identified GHG pollutants and emitters.

- Possibility of promoting electric and hybrid electric vehicles; energy efficient lighting; variable speed drives and efficient motors energy efficient appliances.

\section{Green government procurement}

- None.

Financial and direct trade measures (subsidies, carbon pricing, taxation, R\&D etc.)

- The policy instruments under development include a carbon tax.

\section{International Cooperation (climate finance, technology transfer, international mechanisms etc.)}

- South Africa established a South African Green Fund with an allocated US\$0.11 billion in the 2011 to 2013 budgets to support catalytic and demonstration green economy initiatives. Resources for the Fund will have to be increased in future to enable and support the scaling up of viable and successful initiatives, including contributions from domestic, private sector and international sources.

- The following estimates are of total incremental costs required: estimated incremental cost to expand RE14P in next ten years: US $\$ 3$ billion per year; decarbonized electricity by 2050estimated total of US $\$ 349$ billion from 2010; CCS: $23 \mathrm{Mt}$ CO2 from the coal to liquid plant US $\$ 0.45$ billion; Electric vehicles - US $\$ 513$ billion from2010 till 2050; Hybrid electric vehicles: $20 \%$ by 2030 - US $\$ 488$ billion 


\section{GHG and non-GHG target:}

- In the absence of detailed analysis the assessment of BAU emission and impacts of identified policies and actions of GHG emissions reductions below shall be presented at a later date.

\section{Measures related to the energy sector}

- Increase the use of clean and carbon-neutral energy; construction of a hydroelectricity plant at the Fulla rapids; increase the use country's high potential for solar and wind energy to meet energy demand; increase the efficiency of biomass use (particularly fuel wood and charcoal) in the traditional energy sector and increase efficiency of electricity usage in the formal energy sector and ensuring the best use of hydropower by careful management of water resources.

\section{Green industrial policies}

- Establishment of emissions standards for vehicles.

- Establishment of exhaust testing centers: cars that fail the tests by emitting fumes above allowable emissions levels will be subjected to mandatory repairs or scrapped.

\section{Green government procurement}

- None.

Financial and direct trade measures (subsidies, carbon pricing, taxation, R\&D etc.)

- Consideration of measures to restrict importation of vehicles that do not adhere to allowable emissions levels.

\section{International Cooperation (climate finance, technology transfer, international mechanisms etc.)}

- Regarding climate finance, South Sudan has yet to access the same level of financial resources as other least developed countries owing to its recent existence. It is of utmost importance that South Sudan is extended the opportunity to obtain support from the international donor community and other sources of climate finance to design and implement initiatives aimed at addressing the mitigation and adaptation priorities outlined here within the country's INDCs. South Sudan has begun the process if unlocking access to climate finance through the initiation of the NAPA process that is due to conclude in November 2015. South Sudan also aims to access finance through international carbon markets, and will pursue CDM and REDD+ activities, including the establishment is a Designated National Authority. Subsequent to this, it will require concerted and coordinated effort between the Government of South Sudan and their international development partners to accelerate the process of designing and implementing climate change projects to address both immediate and urgent priorities as well as medium and long-term climate change risks. It is estimated that investment of over $\$ 50$ billion is required for mitigation and adaptation actions across sectors up to 2030 .

- South Sudan's efforts are contingent on availability of technical assistance to develop the necessary regulations, policies and standards as well as financial support for investing in low carbon options. 


\section{GHG and non-GHG target:}

- Sri Lanka aims to reduce the GHG emissions against the BAU Scenarios in the sectors of Energy (Electricity Generation), Transportation, Industry, Waste and Forestry. INDCs for Mitigation intends to reduce the GHG emissions against BAU (BAU) scenario by $20 \%$ in energy sector ( $4 \%$ unconditionally) and by $10 \%$ in other sectors (transport, industry, forests and waste) by $3 \%$ unconditionally and $7 \%$ conditionally by 2030.

- It expects to reduce $20 \%$ GHG emission (approximately $36,010.2 \mathrm{Gg}$ ) in energy sector by 2030 against the $\mathrm{BaU}$ scenario as unconditionally $4 \%$ (approximately $7,202.04 \mathrm{Gg}$ ) and conditionally $16 \%$ (approximately $28,808.16 \mathrm{Gg})$.

\section{Measures related to the energy sector}

- The National Energy Policy and Strategy (NEPS) and Long-term Generation Expansion Plan 2015-2034 anticipates increasing of Non-Conventional Renewable Energy (NCRE) from 20092022 and upward.

- Establishment of large scale wind power farms of $514 \mathrm{MW}$.

- Broadening the solar power electricity generation capacity of the country with participation of private sector and adaptation of advanced technology available. Solar power plants with the capacity of $115 \mathrm{MW}$ will be established.

- Promotion of the use of biomass (fuel wood) and waste (municipal waste, industrial and agricultural waste) by elevating its use in the power generation as a modern and convenient energy source of Sri Lanka, which will be adding 104.62 MW in 2025.

- Promotion Mini and Micro Hydro Power generation projects as an environmental friendly power generation option to national economy. Mini hydro power plants with the capacity of $176 \mathrm{MW}$ will be established.

- The Government of Sri Lanka has given more priority for sustainable energy policies, which are enforced to absorb more Non-Conventional Renewable Energy (NCRE) to the system at least $50 \%$ by 2030 .

- Introduction of energy generation by Waste (waste to energy programmes).

\section{Green industrial policies}

- Introduction of Demand Side Management (DSM) activities in order to improve the load factor of the system and to upgrade the efficiency at consumer end such as increase efficiency of fans, pumps, motors, compressors, refrigerators and Building Management System (BMS) for the commercial, government and domestic sector.

- The proposed INDCs in transport sector would directly or indirectly influence in reduction of GHG emission in transport sector by modifying, adopting and applying with climate smart technology during the period of 2020-2030.

- Establishment of energy efficiency and environmentally sustainable transport systems by 2030 through launching electric buses as a pilot project, introduction of BRT system to encourage public transport or introduction of ITS (Intelligent Transport System) based bus management system.

- Upgrading of Fuel Quality Standards in order to reduce GHG emission.

- Electrify railway from Weyangoda to Panadura and purchase new rolling stock for Sri Lanka Railway

- Electrification of three-wheelers to reduce emissions. 
- Implementation of a new vehicle emission standards.

- Minimize emissions from vehicles that emit excessive smoke on the road: heavy smoke vehicles spotter programme; road side vehicle emission testing programme and inspection and monitoring of vehicle emission testing centres.

- Modernizing and facilitating industries to follow recognized standards related to GHG emission reduction (Environmental Management System such as ISO 14000, ISO 14040 series, ISO 14062- Design for Environment, ISO 14064- Greenhouse emission, standards co-Tex 1000 garment and textile industry, HACCP (Hazard Account Critical Control Points) or ISO 22000/25 certification etc.).

- Continuation of Fuel switching to Biomass in industries.

- Improvement of Industrial energy/water/raw materials efficiency.

- Establishment of Eco-Industrial Parks (EIPS) and villages.

- Applying eco-efficiency and cleaner production.

- Greening the supply chain through introducing life cycle management and industrial symbiosis to managing zero waste.

- Introducing high efficiency motors for entire industrial sector.

\section{Green government procurement}

- Introduce electrified boat service using inland water canal for public transportation to reduce the congestion in roads as well as GHG emission.

\section{Financial and direct trade measures (subsidies, carbon pricing, taxation, R\&D etc.)}

- Encouragement and introduction of low emission vehicles such as electric and hybrid into the system.

- Introduction and Promoting tax structures to promote the sustainable technologies.

- Encouraging industries to reduce GHG emissions through introduction of rewarding system.

International cooperation (climate finance, technology transfer, international mechanisms etc.)

- As a developing nation, the enhanced finance for adaptation and low carbon development will be a necessity to achieve the set intended conditional targets.

- Predominantly mitigation technology transfer and scaling up adaptation technologies are required without burdening the country's socio-economic development. The INDCs can be attained with the right mix of access, affordability and scale of technologies. 


\section{GHG and non-GHG target:}

- Being classified as a LDC, the Republic of Sudan is not obliged to pursue a GHG target.

- Integration of renewable energy in the power system of the Sudan, target of $20 \%$ by 2030

\section{Measures related to the energy sector}

- Wind Energy - $1000 \mathrm{MW}$ (grid connected) will be applicable in strong wind regime areas; Solar PV energy- $1000 \mathrm{MW}$ (on and off-grid) will be applicable in different states within Sudan; Solar CSP technology - $100 \mathrm{MW}$ (grid connected) will be applicable, especially in the northern part of Sudan; Waste to Energy: $80 \mathrm{MW}$ (grid connected) will be applicable in several intended sites; Biomass Potential: $80 \mathrm{MW}$ (grid connected); e.g. the sugar industry; Geothermal Potential: $300 \mathrm{MW}$ in different states of Sudan; Small Hydro Plants: $50 \mathrm{MW}$ (grid connected)/especially in combination with irrigation sites, small hydro plant projects.

- Solar rural electrification through installation of 1.1 million Solar Home Systems (SHSs) up to 2030.

- Reduction of loss in transmission and distribution networks.

- Rehabilitation of the cooling system in Hydroelectric stations.

- Increase in the readiness of the power station - matrix turbines.

- Reduction of the costs of producing electricity and auxiliary consumption from thermal power plants.

- Improvement of specific fuel consumption in thermal power plants.

\section{Green industrial policies}

- Establishment of labeling system for electrical appliances.

\section{Green government procurement}

- None.

Financial and direct trade measures (subsidies, carbon pricing, taxation, R\&D etc.)

- None.

\section{International Cooperation (climate finance, technology transfer, international mechanisms etc.)}

- The international support required to implement the intended contribution in terms of finance, technology and capacity building over a cycle of contributions of 5-10 years, amount to a total of $\$ 12.88$ billion, of which $\$ 1.2$ billion for adaptation and $\$ 11.68$ billion for mitigation. This amount is required to be met from all possible and accessible international climate finance sources. 
GHG and non-GHG target:

- Suriname has taken the initiative to move away from business as usual and to chart a course towards climate compatible development through an enabling framework which has included the preparation and approval of a National Climate Change Policy, Strategy and Action Plan (NCCPSAP).

- Suriname is keen to continue to transition its energy sector to ensure it stays above $25 \%$ renewable by 2025 (conditional).

\section{Measures related to the energy sector}

- The National Energy Plan 2013-2033 outlines the formulation of an energy sector plan and the establishment of an energy authority. Several initiatives are already in an advanced stage such as solar energy for communities in the hinterland, a study on waste-to-energy at the national landfill and micro-hydro power projects in the interior. Other forms of renewable energy to be explored are wind energy as well as biomass-to-energy.

- In consideration are a hydropower project with a potential output of $168 \mathrm{MW}$; a biofuel project that could realize the introduction of ethanol in gasoline with $60 \%$ of vehicles utilizing the blend and at the same time produce $25 \mathrm{MW}$ of power; and $62 \mathrm{MW}$ from thermal energy.

\section{Green industrial policies}

- None.

\section{Green government procurement}

- None.

Financial and direct trade measures (subsidies, carbon pricing, taxation, R\&D etc.)

- None.

- Financial measures related to environmental goods and services

$\circ$ There has been removal of tariffs on renewable energy products.

International Cooperation (climate finance, technology transfer, international mechanisms etc.)

- A $168 \mathrm{MW}$ hydropower project could cost between US\$189 million and US\$1.377 million.

- Upgrading efficiency will require financing estimated at approximately US\$485 million.

- Implementation of conditional contributions to energy, is conservatively estimated at up to US\$1.862 million (considering only hydropower and energy efficiency infrastructure).

- It is assumed that financial mechanisms under the UNFCCC including the Green Climate Fund will become fully operational and easily accessible for SIDS and low lying coastal countries.

- The implementation of the INDC of the Republic of Suriname will require financial support. Several actions have been identified in the energy and forestry sectors that would contribute to mitigation. As estimate of these costs is US\$2.492 billion. For critical adaptation needs, Suriname required an estimated US $\$ 1$ billion to support its climate resilience program of activities. The total costs for the implementation of the INDC of the Suriname are therefore estimated at US $\$ 3.492$ billion. 


\section{GHG and non-GHG target:}

- Swaziland aims to double the share of renewable energy in the national energy mix by 2030 , relative to 2010 levels.

\section{Measures related to the energy sector}

- The contribution covers grid and off-grid applications where Swaziland will: implement smallscale, decentralized renewable energy technologies to improve energy access in rural areas. Increase the use of grid-connected renewable technologies with fuel sources such as waste, solar, bagasse (from the sugar industry) and wood chips.

- Swaziland's contribution is to introduce the commercial use of a $10 \%$ ethanol blend in petrol by 2030. This is additional to the energy sector contribution discussed above. Bagasse and molasses are by-products from this mature industry and can be used as feedstock for the production of ethanol.

\section{Green industrial policies}

- None, but the INDC explicitly covers the industrial processes and product use sectors.

\section{Green government procurement}

- None.

Financial and direct trade measures (subsidies, carbon pricing, taxation, R\&D etc.)

- None.

International Cooperation (climate finance, technology transfer, international mechanisms etc.)

- Mitigation actions have clear GHG reduction potential and could be converted to carbon credits. Swaziland intends to sell emission reductions units through international and regional carbon markets and/or carbon pricing mechanisms that may be established under the new agreement. 


\section{GHG and non-GHG target:}

- Switzerland commits to reduce its greenhouse gas emissions by $50 \%$ by 2030 compared to 1990 levels, corresponding to an average reduction of greenhouse gas emissions by 35\% over the period 2021-2030.

- By 2025, a reduction of greenhouse gases by $35 \%$ compared to 1990 levels is anticipated.

- Indicative goal to reduce emissions by 2050 by $70-85 \%$ compared to 1990 including use of international credits as well as the vision of reduce per capital emissions.

\section{Measures related to the energy sector.}

- Switzerland will realize its INDC mainly domestically and will partly use carbon credits from international mechanisms.

\section{Green industrial policies}

- None.

\section{Green government procurement}

- None.

Financial and direct trade measures (subsidies, carbon pricing, taxation, R\&D etc.)

- None.

\section{International Cooperation (climate finance, technology transfer, international mechanisms etc.)}

- Use of carbon credits with high environmental standards: Switzerland will use carbon credits from international mechanisms that deliver real, permanent, additional and verified mitigation outcomes and meet high environmental standards. Quality criteria which are at least in line with those of Switzerland's current national legislation will be applied. Switzerland intends to use the CDM. In this context, Switzerland supports the revision of its modalities and procedures to fit in the new climate regime. Switzerland also intends to use, as appropriate, the new market mechanisms under the Convention (NMM, activities under the FVA).

- Avoidance of double counting: Switzerland intends to include the above-mentioned carbon credits in accounting for its emission reduction commitment. For the CDM under its current use and operation, it is assumed that only the acquiring Party will account for the emission reductions covered by the credits acquired from the host Party. Beyond this, Switzerland supports the reform of the CDM in the context of host country Parties having also emission reduction commitments/contributions. For new market mechanisms, Switzerland supports the elaboration of UNFCCC rules for avoiding double counting of emission reductions, or otherwise appropriate arrangements will be necessary. 


\section{GHG and non-GHG target:}

- A flexible target, not exceeding $80-90 \%$ of the 1990 level by 2030, which amounts to 1.7-2.2 tons in CO2 equivalent per capita, has been determined as the country's contribution to anthropogenic greenhouse gas emission reductions.

- The potential for reducing greenhouse gas emissions in Tajikistan to achieve a target of $65-75 \%$ of the 1990 level by 2030, which amounts to 1.2-1.7 tons in CO2 equivalent per capita. It will be possible in case of implementation of investment projects and national programmes in the sphere of power industry, transport, agriculture and forestry and water resources etc.

\section{Measures related to the energy sector}

- Development of strategies and action plans for climate sensitive investment and fulfillment of the intentions of the Tajikistan with respect to greenhouse gas emissions and climate adaptation.

\section{Green industrial policies}

- None.

\section{Green government procurement}

- None.

Financial and direct trade measures (subsidies, carbon pricing, taxation, R\&D etc.)

- None.

International Cooperation (climate finance, technology transfer, international mechanisms etc.)

- None. 
GHG and non-GHG target:

- Tanzania aims to reduce greenhouse gas emissions economy wide between $10-20 \%$ by 2030 relative to the BAU scenario of 138-153 million tonnes of carbon dioxide equivalent (MtCO2e) - gross emissions, depending on the baseline efficiency improvements, consistent with its sustainable development agenda.

\section{Measures related to the energy sector}

- Enhanced use of natural gas with 53.28 trillion cubic feet discovered reserves of which to date over 100 million cubic feet are exploited to produce $501 \mathrm{MW}$. There is also expanded use of renewable energy sources such as geothermal (with a potential of $5 \mathrm{GW}$ ); solar with average sunshine of more than 9 houses per day; hydro with a potential of $4.7 \mathrm{GW}$ (while the installed capacity is $561 \mathrm{MW}$ ); and wind with speed of 0.9-9.9 m/w across many parts of the country.

- Waste management systems in the country are being enhanced by encouraging private sector and community involvement in waste to energy management approaches.

- Exploration and investing in the energy diversification system to ensure overall energy security while contributing to energy efficiency; promotion of clean technologies for power generation; and diverse renewable sources such as geothermal, wind, solar and renewable biomass;

- Promotion of energy efficient technologies for supply, transmission/transportation and promotion of rural electrification.

\section{Green industrial policies}

- None.

\section{Green government procurement}

- None.

Financial and direct trade measures (subsidies, carbon pricing, taxation, R\&D etc.)

- None.

\section{International Cooperation (climate finance, technology transfer, international mechanisms etc.)}

- An initial estimate of immediate and start-up financing needs for enhancing adaptive capacity is about $\$ 150$ million. In addition, about $\$ 500$ million per year is needed to address climate change adaptation and building resilience up to 2020, increasing up to $\$ 1$ billion per year by 2030. These costs are likely to increase further depending on global mitigation efforts. Estimated costs are up to US $\$ 60$ billion by 2030 in mitigation investments in Tanzania.

- Implementation will strongly depend on how he international community meets its commitments in terms of financial and technological support. 


\section{GHG and non-GHG target:}

- Thailand intends to reduce its greenhouse gas emissions by $20 \%$ from the projected BAU level by 2030.

- The level of contribution could increase up to $25 \%$, subject to adequate and enhanced access to technology development and transfer, financial resources and capacity building support through a balanced and ambitious global agreement under the UNFCCC.

\section{Measures related to the energy sector}

- Power Development Plan (PDP) sets a target to achieve a $20 \%$ share of power generation from renewable sources in 2036. The Alternative Energy Development Plan (AEDP) aims to achieve a $30 \%$ share of renewable energy in the total final energy consumption in 2036 . The EEP plans to reduce the country's energy intensity by $30 \%$ below the 2010 level in 2036 .

- Promotion of power generation from waste-to-energy technologies.

\section{Green industrial policies}

- None.

\section{Green government procurement}

- None.

Financial and direct trade measures (subsidies, carbon pricing, taxation, R\&D etc.)

- Thailand launched several support mechanisms such as feed-in tariffs, tax incentives and access to investment grants and venture capital to promote renewable energy.

- Incentives have to be created for technology developers to cooperate and share technology knowledge to enable technology transfer on a larger scale.

- A vehicle tax scheme based on CO2 emission was approved and will become effective beginning 2016.

International cooperation (climate finance, technology transfer, international mechanisms etc.)

- International financial support mechanisms such as technical assistance and technology transfer funds for purchasing intellectual property rights for a free distribution of clean energy technologies would be very valuable to accelerate diffusion of renewable energy technologies for developing countries.

- Some of the key barriers for the energy sector include, for instance, limitation of grid connection due to inadequate capacity of transmission lines, lack of support by financial institutions for energy efficiency and renewable energy investments, lack of domestic technological and technical resources and negative public perception particularly against waste-to-energy and biomass power plants. 


\section{GHG and non-GHG target:}

- Under the business-as-usual (BAU) scenario (accounting for the implementation of already programmed measures), the overall reduction rate in 2030 would be $11.14 \%$ compared with Togo's total 2030 emissions based on the baseline year 2010). This reduction in emissions is attributed to the implementation of sectoral work. The conditional target for additional GHG emissions reduction, according to the most ambitious scenario, is estimated at $20 \%$ compared to the dynamic BAU. The conditional target for the total reduction would therefore be $31.14 \%$ in 2030 , compared to the projections if no measures were to be applied.

\section{Measures related to the energy sector}

- In the energy sector, promotion of household use of biomass, plus solar electricity and road transport. As concerns biomass, this will entail the implementation of a proactive policy (with incentives, support and training for craftsmen, appropriate distribution channels, etc.)

- Adoption of a national energy policy, revision of the electricity law and creation of a national rural electrification agency.

- Development of renewable energies (target of $4 \%$ of the energy mix): promotion of biofuels and reclamation of degraded land; seeking out technical and financial partners for the production of new and renewable energies; sustainable management of traditional energy sources (firewood and charcoal) (7 \$million); development of mini hybrid networks for rural electrification (30 \$million).

- Hydro-electric construction at the Adjrarala Dam (start-up is imminent); pilot programme for the electrification of 22 villages equipped with solar PV kits; distribution of 13,000 solar street lights, project for the construction of a $5 \mathrm{MW}$ solar power plant by the CEB at Kara; project for the construction of a $20 \mathrm{MW}$ solar plant at MANGO, with financing by the WAEMU; project for connecting a ${ }^{*} 5 \mathrm{MW}$ PV solar array to the network (offers being considered as at June 2015); a $24 \mathrm{MW}$ wind power project by Delta Wind; rural electrification of 65 villages with Indian financing; project for the rural electrification of 20 locales funded by BIE; project for the creation of a rural electrification agency.

\section{Green industrial policies}

- Implementation of electricity-saving strategies (9 \$million).

- Promotion of new, clean technologies in the building sector (\$50 million).

\section{Green government procurement}

- None.

Financial and direct trade measures (subsidies, carbon pricing, taxation, R\&D etc.)

- Establishment of incentives for renewable energy use.

- Reducing the average age of imported vehicles (to 5-7 years) and setting quality standards.

- Financial measures related to environmental goods and services

- Tax remission on imports of equipment for solar and other renewable engines (40 \$million); 
International Cooperation (climate finance, technology transfer, international mechanisms etc.)

- The total funding required is estimated at approximately US\$1.54 billion between 2020 and 2030.

- To implement its INDC, Togo will need 3.54 billion $\$, 1.54 \$$ billion for adaptation, 1.10 billion for mitigation, $0.4 \$$ billion for technology transfer and $0.4 \$$ billion for capacity building. These estimates represent additional financing needs over and above the cost of any national decisions that would have been implemented in any case, in view of the defined national priorities. 


\section{GHG and non-GHG target:}

- The Tonga Energy Roadmap BAU forecast predicts a $35 \%$ increase in diesel consumption for electricity generation from 2006-2020, increasing electricity access to $100 \%$ and no GHG abatement measures.

- A 50\% renewable energy contribution in 2020 would equate to a reduction of 9.4 million liters of diesel per annum or approximately $27 \mathrm{Gg}$ CO2e.

\section{Measures related to the energy sector}

- $70 \%$ of electricity generation from renewable sources by 2030 .

- Improve Energy efficiency through reduction of electricity line losses to $9 \%$ by 2020 (from a baseline of $18 \%$ in 2010).

- Plan to increase from $50 \%$ to $100 \%$ of RE in total electricity production by 2030 . The Government has been proactively working towards the RE target with over a million litres of diesel fuel oil projected to be saved per annum from March 2015. The Government also aims to replace all diesel-based water pumping engines by 2017 using solar power. Implementation of the Tonga Energy Road Map will help Tonga to achieve its energy strategic objectives of accessible to affordable energy prices, improve accessible to clean energy and reliable power supply.

- $50 \%$ of electricity generation from renewable sources by 2020, in 2015 renewable energy accounts for approximately $9 \%$ of total electricity generation, with confirmed and funded investments taking this to $13 \%$ in 2016.

- Tonga's contribution: $70 \%$ of electricity generation from renewable sources by 2030 ; improve energy efficiency through reduction of electricity line losses to $9 \%$ by 2020 (from a baseline of 18\% in 2010); to double the 2015 number of Marine Protected Areas by 2030; Sector Emission Reduction Targets- Transport, Agriculture, Environment Friendly Waste Management and Reforestation; Other Sectors Climate Resilience - Public Infrastructures, foreshore protection, buildings and houses- Emissions reduction benefits of these activities have not yet been estimated; however additional emissions reductions delivered through these activities may be substituted for electricity sector contributions.

\section{Green industrial policies}

- None.

\section{Green government procurement}

- None.

Financial and direct trade measures (subsidies, carbon pricing, taxation, R\&D etc.)

- None.

International cooperation (climate finance, technology transfer, international mechanisms etc.)

- None. 


\section{GHG and non-GHG target:}

- Trinidad and Tobago's aim is to achieve a reduction objective in overall emissions from the three sectors by $15 \%$ by 2030 from BAU, which are absolute terms in an equivalent of 103,000,000 of CO2e. The estimated cost of meeting this objective is US\$ 2 billion, which is expected to be met partly through domestic funding and conditional on international financing including through the Green Climate Fund. In this regard, Trinidad and Tobago will commit to unconditionally reduce its public transportation emissions by 30\% for 1,700,000 CO2e compared to 2013 levels by December 31, 2030.

- Unconditional 30\% reduction in GHG emissions by December 31, 2030 in the public transportation sector compared to a business as usual (BAU) scenario (Reference year 2013).

- Conditional reduction achievable under certain conditions which would bring the total GHG reduction to 15\% below BAU emission levels by December 31, 2030.

\section{Measures related to the energy sector}

- Trinidad and Tobago already produces all of its electricity from natural gas and is working towards achieving greater efficiency through combined cycle generation at all its power plants.

\section{Green industrial policies}

- None.

\section{Green government procurement}

- None.

Financial and direct trade measures (subsidies, carbon pricing, taxation, R\&D etc.)

- None.

\section{International Cooperation (climate finance, technology transfer, international mechanisms etc.)}

- The estimated cost of achieving the reduction objectives is US\$2 billion, which is expected to be met partly through domestic funding and conditional on international climate financing including through the Green Climate Fund. 


\section{GHG and non-GHG target:}

- Tunisia commits to reduce its greenhouse gas emissions across all sectors (energy; industrial processes; agriculture, forestry and other land use; waste) in order to lower its carbon intensity by $41 \%$ in 2030 , relative to the base year 2010 .

- Aims to reduce its carbon intensity unconditionally and through its own efforts by $13 \%$ compared to 2010 , i.e. by around $1 / 3$ of its INDC. To achieve the rest of its objective, i.e. an additional drop in carbon intensity of $28 \%$ in 2030 compared to 2010.

- As part of the energy transition policy advocated by the State, it is estimated that the sector will reduce its carbon intensity in 2030 by $46 \%$ compared with 2010 .

\section{Measures related to the energy sector}

- Increase in the use of renewable energies, not least through the Tunisian Solar Plan (PST). This will raise the share of renewable energies in electricity production to $14 \%$ in 2020 and to $30 \%$ in 2030 , whereas it stood at only $4 \%$ in 2015 .

- Achievement of an installed renewable energy capacity of 3,815 MW in 2030, including 1,755 MW for wind power, 1,610 MW for solar PV and $450 \mathrm{MW}$ for concentrated solar power (CSP).

- As regards solar heating, Tunisia intends to triple the solar water heater distribution rate, which will exceed $220 \mathrm{~m} 2$ of collectors per 1,000 inhabitants in 2030, compared to 73 in 2015.

- The mitigation plan provides for the implementation, from 2016, of a plan to install facilities to transform solid waste into RDF (refuse derived fuel) intended for cement facilities as well as a programme for introducing degasification systems in controlled landfills. It is planned to recover electricity from captured gases, at least at the main landfills.

- The mitigation plan in the sanitation sector provides in particular for the installation of solar PV capacity at water treatment plants (STEPs), biogas digesters for electricity production and a reduction in the chemical oxygen demand (COD) of industrial wastewater.

\section{Green industrial policies}

- Around 20 energy efficiency actions have been included in the calculation of avoidable emissions, covering the entire industrial, building, transport and agricultural sectors. This should allow primary energy demand to decrease by some $30 \%$ by 2030 , compared to the baseline.

\section{Green government procurement}

- None.

\section{Financial and direct trade measures (subsidies, carbon pricing, taxation, R\&D etc.)}

- To support the financing needs of its mitigation objective, Tunisia would like to use carbon market mechanisms in addition to the direct financial supports listed above, particularly for the following programmes:

- Tunisian Solar Plan

- Mitigation in the cement industry and in any other sector which tends to be involved in carbon markets

- Energy efficiency and renewable energies in the building sector. 
International Cooperation (climate finance, technology transfer, international mechanisms etc.)

- Tunisia is relying on the support of the international community for funding, capacity building and technology transfer to reduce its carbon intensity unconditionally and through its own efforts by $13 \%$ compared to 2010 , i.e. by around $1 / 3$ of its INDC.

- Implementation of the Tunisian contribution towards mitigation requires substantial funds to be mobilized - an estimated 18 billion $\$$ - to cover investment needs and finance capacity building programmes. The national effort exclusively concerns the energy sector, which accounts for the most significant part of the investment needs.

- The additional costs of the necessary adaptation measures for these sectors and fields will come to some 2 billion dollars and should be borne completely by the international community $s$ part of the global fight against climate change. Altogether, the total additional financing required for mitigation and adaptation would be around 20 billion $\$$ to fund investment requirements and capacity building.

- The mitigation objective would require a large total investment amount to be mobilized around 17.5 billion $\$$ over the period $2015-2030$ distributed among the following sectors:

$\circ$ Energy $(14,917$ million $\$)$

- Energy Efficiency(6,991 million \$)

- Renewable Energy (7,926 million \$)

- Waste (972 million \$)

- Solid waste (70 million \$)

- Sanitation (902 million \$)

- International support should focus on funding the various remaining types of investment needs (concessional lines of credit, donations, direct investment, integration into carbon markets, etc.).

- In the energy sector, some of the international support should serve to bolster the Energy Transition Fund (FTE). This fund was established by the Tunisian State in 2014 as a central instrument for implementing its energy transition agenda. The international effort will also focus on the funding of capacity building and technology transfer programmes. 


\section{GHG and non-GHG target:}

- The Republic of Turkey aims to reduce $21 \%$ GHG emissions from the BAU level by 2030.

\section{Measures related to the energy sector}

- Increase in the capacity of production of electricity from solar power to $10 \mathrm{GW}$ until 2030; increase in the capacity of production of electricity from wind power to 16 GW until 2030; development of the full hydroelectric potential; commissioning of a nuclear power plant until 2030; reduction of electricity transmission and distribution losses to $15 \%$ at 2030 ; rehabilitation of public electricity generation power plants; establishment of micro-generation, co-generation systems and production on site at electricity production.

- Recovery of energy from waste by using processes such as material recycling of wastes, biodrying, bio-mechanization, composting advanced thermal processes or incineration; recovery of methane gas from landfill gas from managed and unmanaged landfill sites.

\section{Green industrial policies}

- Utilization of industrial wastes as an alternative raw material or alternative fuel in other industrial sectors, through industrial symbiosis approach; conducting relevant studies to utilitie wastes generated from breeding farms and poultry farms.

- Necessity for new residential buildings and service buildings to be energy efficient in accordance with the Energy Performance of Buildings Regulation; creating Energy Performance Certificates for new and existing buildings so as to control energy consumption and greenhouse gas emissions and to reduce energy consumption per square meter;

- Reduction of consumption of primary energy sources of new and existing buildings by means of design, technological equipment, building materials.

- Implementation of green port and green airport projects to ensure energy efficiency.

- Reduction of emission intensity with the implementation of National Strategy and Action Plan on Energy Efficiency; Increasing energy efficiency in industrial installations.

\section{Green government procurement}

- None.

Financial and direct trade measures (subsidies, carbon pricing, taxation, R\&D etc.)

- Development of channels that promote the use of renewable energy sources (loans, tax reduction, etc.).

- Implementing special consumption tax exemptions for maritime transport.

- Provision of financial support to energy efficiency projects.

- Support studies to increase use of waste as an alternative fuel at the appropriate sectors

- Financial measures related to environmental goods and services

$\circ$ Promoting alternative fuels and clean vehicles.

International Cooperation (climate finance, technology transfer, international mechanisms etc.) 
- Turkey will use domestic sources and receive international financial, technological, technical and capacity building support, including finance from the Green Climate Fund.

- Turkey aims to use carbon credits from international market mechanisms to achieve its 2030 mitigation target in a cost-effective manner and in accordance with the relevant rules and standards. 


\section{GHG and non-GHG target:}

- If financial and technological support is provided by developed countries, Turkmenistan could achieve zero growth in emissions and even reduce them up to 2030.

Measures related to the energy sector

- None.

Green industrial policies

- None.

Green government procurement

- None.

Financial and direct trade measures (subsidies, carbon pricing, taxation, R\&D etc.)

- None.

International Cooperation (climate finance, technology transfer, international mechanisms etc.)

- None. 


\section{GHG and non-GHG target:}

- Tuvalu commits to reduction emissions of green-house gases from the electricity generation (power) sector, by $100 \%$, i.e. almost zero emissions by 2025 .

- Indicative quantified economy-wide target for a reduction in total emissions of GHGs from the entire energy sector to $60 \%$ below 2010 levels by 2025. These emissions will be further reduced from the other key sectors, agriculture and waste, conditional upon the necessary technology and finance.

Measures related to the energy sector

- $50 \%$ of electricity is derived from renewables, mainly solar, and this figure will rise to $75 \%$ by 2020 and $100 \%$ by 2025 .

- Development of $6 \mathrm{MW}$ renewable energy electricity generation capacity in next 8 years.

- The renewable electricity programme in Funafuti will comprise of the installation of PV arrays with battery storage because this technology is well proven in Tuvalu.

- Under a World Bank project proposal wind turbines will be installed from 2016 onwards.

- A wind-solar mix will optimize the level of battery storage required and of diesel generation required.

- Conversion or replacement of the existing diesel generators to run on bio-diesel fuel was proposed to take place in the last stage of the renewable electricity programme. It is estimated that $5 \%$ of the annual electricity production will be supplied from bio-diesel generation.

- Tuvalu aims to implement various solar energy plants to the tune of $1947 \mathrm{~kW}$ and further the World Bank project implementing solar and wind energy projects to the tune of $925 \mathrm{~kW}$ and $200 \mathrm{~kW}$.

- A proposed World Bank project is aimed at providing additional energy generation from solar PV and will include investment in modest wind-power capacity. The solar PV investment will provide sufficient battery storage and a power-conditioning system to ensure grid stability, as intermittent RE sources become an increasingly dominant portion of Fogafale's power mix.

\section{Green industrial policies}

- Increasing energy efficiency on Funafuti by $30 \%$.

\section{Green government procurement}

- None.

Financial and direct trade measures (subsidies, carbon pricing, taxation, R\&D etc.)

- None.

International cooperation (climate finance, technology transfer, international mechanisms etc.)

- No intention to use market based mechanisms to meet commitments.

- The goal to pursue a zero carbon development pathway by 2050 is dependent on availability of finance and technology. 
GHG and non-GHG target:

- Uganda aims to reduce $22 \%$ of overall national GHG emissions in 2030.

\section{Measures related to the energy sector}

- Commitment to undertake a number of policies and measures to support low-carbon development in key priority sectors.

- Construction of enabling infrastructure for electricity sector development, including power lines, substations and transmission facilities. Development of the electricity sector holds great mitigation potential for Uganda due to the potential offsetting of wood and charcoal burning, and the consequential deforestation.

- Achieve a total of at least 3,200 MW RE generation capacity by 2030, up from 729 MW in 2013

- Promotion and wider solar uptake of solar energy systems.

- Access to and diffusion of appropriate clean technologies.

- Setting up of public-private partnerships.

- Promote and encourage climate change research and development, information exchange in all sectors impacted on by climate change and climate technology.

\section{Green industrial policies}

- Development and enforcement of building codes for energy efficient construction renovation.

\section{Green government procurement}

- None.

Financial and direct trade measures (subsidies, carbon pricing, taxation, R\&D etc.)

- Policies and regulations to promote cleaner fuels, and more fuel efficient vehicle technology.

\section{International cooperation (climate finance, technology transfer, international mechanisms etc.)}

- Uganda intends to meet its commitment and/or increase the level of its contribution through the use of international market mechanisms where appropriate, building upon the experience of the Clean Development Mechanism and other existing market mechanisms.

- The upfront capital investment for the renewable energy installations has been estimated at US $\$ 5.4$ billion over the next 10 years.

- Implementation of these policies and measures assumes the continuation of ongoing and planned international financial, technology transfer and capacity building support to complement domestic efforts as set out in 2015 National Climate Change Policy. 
GHG and non-GHG target:

- Ukraine will not exceed $60 \%$ of 1990 GHG emissions level in 2030. The declared GHG emissions level does not account for the participation of Ukraine in international market mechanism.

Measures related to the energy sector

- None.

\section{Green industrial policies}

- None.

\section{Green government procurement}

- None.

Financial and direct trade measures (subsidies, carbon pricing, taxation, R\&D etc.)

- None.

International cooperation (climate finance, technology transfer, international mechanisms etc.)

- Ukraine will participate actively in the development of existing international market mechanisms and implementation of new ones. 
GHG and non-GHG target:

- The UAE will pursue a portfolio of actions, including an increase of clean energy to $24 \%$ of the total energy mix by 2021.

\section{Measures related to the energy sector}

- The UAE national oil company was the first in the region to promote the reduction of gas flaring, overall performance indicators will be improved through carbon abatement measures and increased resource efficiency.

- The UAE has set a target of increasing clean energy contribution to the total energy mix from $0.2 \%$ in 2014 , to $24 \%$ by 2021 . This will be achieved through renewable and nuclear energy.

\section{Green industrial policies}

- The UAE continues to improve the emission standards for new motor vehicles, in accordance with European emission standards, as well as through the introduction of standard labels. These initiatives target both improvements in fuel economy and reduction in local air pollution.

- The UAE is comprehensively targeting emissions from its building sector, through green building regulations, efficiency standards, retrofit programs and support structures for energy service companies.

- Comprehensive infrastructure investments are being undertaken to move towards district cooling and improve efficiency as compared to decentralized cooling.

- The UAE introduced the region's first efficiency standards for air-conditioning units, eliminating the lowest-performing $20 \%$ of units on the market, and is introducing efficiency standards for refrigeration and other appliances. The UAE has also established an indoor lighting standard that introduces energy efficient lighting products and phases-out inefficient lighting products in the UAE market.

\section{Green government procurement}

- The Emirate of Abu Dhabi has set targets to shift $25 \%$ of government vehicle fleets to compressed natural gas.

\section{Financial and direct trade measures (subsidies, carbon pricing, taxation, R\&D etc.)}

- The introduction of a new fuel pricing policy, which will put the UAE in line with global prices. This reform aims to support the national economy, lower fuel consumption, and protect the environment.

- The UAE will also introduce comprehensive regulations for electric vehicles, so as to facilitate their uptake domestically.

- The UAE recognizes the value of energy and water tariff reform in reducing inefficiencies and promoting low-carbon development, as well as addressing energy security concerns. To this end, utility authorities in the UAE have introduced a number of initiatives and policies, and revised the country's tariffs for commercial and industrial customers, so as to reflect the cost of generation by 2021 .

International cooperation (climate finance, technology transfer, international mechanisms etc.) 
- None. 


\section{GHG and non-GHG target:}

- The US intends to achieve an economy-wide target of reducing its greenhouse gas emissions by $26-28 \%$ below its 2005 level in 2025 and to make best efforts to reduce its emissions by $28 \%$.

\section{Measures related to the energy sector}

- Under the Clean Air Act, the US Environmental Protection Agency has approved the use of specific alternatives to high-GWP HFCs in certain applications through the Significantly New Alternatives Policy program.

- Under the Clean Air Act, the US EPA is developing standards to address methane emissions from landfills and the oil and gas sector.

- Executive Order 13693 issued on $25^{\text {th }}$ March 2015, has set a new target to reduce these emissions $40 \%$ below 2005 levels by 2025 .

\section{Green industrial policies}

- Under the Clean Air Act, the US Department of Transportation and the US Environmental Protection Agency adopted fuel economy standards for light-duty vehicles for model years 2012-2025 and for heavy-duty vehicles for model years 2014-2018.

- Under the Clean Air Act, the US Department of Transportation and the US Environmental Protection Agency are moving to promulgate post-2018 fuel economy standards for heavy-duty vehicles.

- Under the Energy Policy Act and the Energy Independence and Security Act, the US Department of Energy has finalized multiple measures addressing buildings sector emissions including energy conservation standards for 29 categories of appliances and equipment as well as building code determination for commercial buildings.

\section{Green government procurement}

- None.

Financial and direct trade measures (subsidies, carbon pricing, taxation, R\&D etc.)

- None.

International cooperation (climate finance, technology transfer, international mechanisms etc.)

- The US does not intend to utilize international market mechanisms to implement its 2025 target. 


\section{GHG and non-GHG target:}

- 8 intensity targets and 1 fixed level target. Overall, Uruguay expects to be a net CO2 sink by 2030. In addition, based on these estimates, it expects to maintain relatively stable levels of non-CO2 gases emissions by 2030 compared to current values, despite an expected growth in the economy for the period of $60 \%$.

\section{Measures related to the energy sector}

- Uruguay has made great efforts within the framework of the National Energy Policy 2005-2030 to achieve a clean energy mix: $59 \%$ of the global primary energy mix is currently renewable, which amounts to $83 \%$ for the total energy consumption of the industrial sector and $93 \%$ for power generation. With regards to transport, the use biodiesel accounts for $7 \%$ and bioethanol $10 \%$ of the total vehicle fleet, both with entire domestic production.

- By 2017, emissions from the domestic power generation system will be $17 \mathrm{~g} \mathrm{CO} / \mathrm{kWh}$, which accounts for $3 \%$ of the global average. This will be achieved with $40 \%$ of non-conventional renewable energy sources (mainly wind, but also PV and biomass waste), in addition to 55\% hydropower (estimating an average annual rainfall). Although this figure would increase in the following decades after reaching the hydro-wind complementation threshold, it could remain close to 2017 value, if storage systems were to be incorporated through additional means of implementation.

\section{Green industrial policies}

- None.

\section{Green government procurement}

- None.

Financial and direct trade measures (subsidies, carbon pricing, taxation, R\&D etc.)

- None.

International Cooperation (climate finance, technology transfer, international mechanisms etc.)

- None. 


\section{GHG and non-GHG target:}

- The Republic of Vanuatu commits to $100 \%$ below BAU emissions for electricity sub-sector and $30 \%$ for energy sector as a whole.

\section{Measures related to the energy sector}

- The mitigation contribution for the Vanuatu INDC submission is a sector specific target of transitioning to close to $100 \%$ renewable energy in the electricity sector by 2030 .

- This target would replace nearly all fossil fuel requirements for electricity generation in the country and be consistent with the National Energy Road Map (NERM) target of 65\% renewable energy by 2020.

- The other mitigation measures in the Vanuatu National Energy Roadmap (2013-2020), the Scaling Up Renewable Energy in Low Income Countries (SREP) report and Vanuatu's Renewables Readiness Assessment (RRA) report undertaken by IRENA.

- Doubling of the wind installed capacity to $5.5 \mathrm{MW}$ by 2025.

- Installing $10 \mathrm{MW}$ grid connected solar PV by 2025.

- Commissioning the proposed first stage $4 \mathrm{MW}$ Geothermal plant by 2025.

- Adding $10 \mathrm{MW}$ grid connected solar PV by 2030.

- Commissioning the second stage $4 \mathrm{MW}$ Geothermal plant by 2030.

- Substituting and/or replacement of fossil fuels with coconut oil based electricity generation.

- $100 \%$ below BAU emissions for electricity sub-sector and $30 \%$ for energy sector as a whole.

- Rural Electrification Nationally Appropriate Mitigation Action (NAMA) (US\$ 5 million indicative).

- Off-grid renewable energy projects under Scaling Up Renewable Energy in Low Income Countries Program (US $\$ 34.2$ million).

- Energy efficiency measures to be pursued across the board to enable $15 \%$ savings in the energy sector.

\section{Green industrial policies}

- None.

\section{Green government procurement}

- None.

Financial and direct trade measures (subsidies, carbon pricing, taxation, R\&D etc.)

- None.

\section{International cooperation (climate finance, technology transfer, international mechanisms etc.)}

- The proposed interventions would need substantial external funding of around US\$180 million to proceed at the time frame needed. In addition, substantial technology transfer would be required including institutional support and training. 
GHG and non-GHG target:

- The National Mitigation Plan will aim to reduce the country's emissions by at least $20 \%$ by 2030 in relation to the baseline scenario, understood as a hypothetical scenario in which the plan is not implemented. The degree to which this goal is achieved will depend on the fulfillment of the commitments of developed countries in terms of provision of finance, technology transfer and capacity building pursuant to Article 4.7 of the Convention.

\section{Measures related to the energy sector}

- About $70 \%$ of the energy in Venezuela is hydroelectric; this means that the country is exceptionally clean in its energy matrix but also highly vulnerable to drougth.

- Construction of two wind farms high capacity (Guajira and Paraguana).

- Implementation of the program Sembrando light that will provide electricity to isolated communities through hybrid systems, wind and solar energy. The management of associated facilities has involved 1,327 training activities with 14,617 beneficiaries.

- The industry is currently developing a number of projects to minimize or use of gas flared and / or vented by PDVSA in its exploration and production; this implies the adequacy of operations and facilities in terms of infrastructure and facilities for the use of natural gas.

\section{Green industrial policies}

- National project to phase out substances that deplete the ozone layer: mainly in refrigeration, air conditioning and polyurethane foams. Through the plan of training and awareness of stakeholders on the environmental danger posed by the misuse of halogenated refrigerants as well as the adequacy of the applicable legal standard. This has meant a reduction of 2.5 Mton CO2eq.

- Enactment of legislation on Energy Efficiency, on the rational and efficient use of energy; Resolutions on Energy Efficiency for Public and Private Sector; Technical Regulations on energy efficiency standards for electrical appliances: A / A, Refrigerators, LFC.

- Promotion of environmentally friendly building systems and eco-efficient housing systems.

- Ministerial decisions to reduce electricity consumption in the public and private sector. Obtained to date a reduction of $12 \%$ in electricity consumption for public and $8 \%$ for the private sector.

- Establishment of ferrous and non-ferrous scrap as an input of national interest for the production process, in order to meet the cost structure of the products and care for the environment and energy efficiency.

\section{Green government procurement}

- None.

Financial and direct trade measures (subsidies, carbon pricing, taxation, R\&D etc.)

- Gradual import ban of incandescent bulbs.

- Electricity tariffs escalating with consumption.

- Import ban on inefficient devices.

International cooperation (climate finance, technology transfer, international mechanisms etc.) 
- Removal of international carbon market schemes legitimizing buying pollution rights and unpunished destruction of the planet.

- The degree to which this goal is achieved will depend on the fulfillment of the commitments of developed countries in terms of provision of finance, technology transfer and capacity building pursuant to Article 4.7 of the Convention.

- Promotion of alternative means of payment that go beyond the use of coins (paper and metal), facilitating the establishment of fair trade among South American peoples and allied countries, while the influence of the US dollar as gold standard in international trade is changed. 
GHG and non-GHG target:

- Viet Nam's INDC identifies the GHG reduction pathway in the 2021-2030 period. With domestic resources GHG emissions will be reduced by $8 \%$ by 2030 compared to the BAU scenario. The above-mentioned contribution could be increased up to $25 \%$ with international support.

\section{Measures related to the energy sector}

- Innovation of technologies and application of advanced management and operation procedures for efficient and effective use of energy in production, transmission and consumption, especially in large production facilities where energy consumption is high.

- Improvement of national energy security by developing and exploiting different energy sources, while simultaneously using energy sources effectively.

- Change in the energy structure towards a reduced share of fossil fuel, encouraging the exploitation and use of renewable and low GHG emission energy sources.

- Utilisation of landfill gas and solid waste combustion for power generation.

\section{Green industrial policies}

- Encouragement for buses and taxis to use compressed natural gas and liquefied petroleum gas (LPG); implement management solutions for fuel quality, emissions standards, and vehicle maintenance.

- Labeling of energy-saving equipment and issue national standards for the quality of equipment.

- Application of energy savings and efficiency, and renewable energy applications in the residential sector, trade and services.

- Establishment of standards on fuel consumption and develop a roadmap to remove obsolete and energy consuming technologies in energy production and consumption systems.

\section{Green government procurement}

- None.

Financial and direct trade measures (subsidies, carbon pricing, taxation, R\&D etc.)

- Application of market instruments to promote structural change and improve energy efficiency; encourage the use of clean fuels; support the development of renewable energy; implement the roadmap to phase out subsidies for fossil fuels.

- Development and implementation of financial and technical mechanisms and policies to support research and the application of appropriate advanced technologies; exploit and optimize the use of renewable energy sources, both on-grid as well as off-grid.

- Development of a renewable energy technology market, domestic industries and local service providers.

International Cooperation (climate finance, technology transfer, international mechanisms etc.)

- Development and implementation of financial and technical mechanisms and policies to support research and the application of appropriate advanced technologies; exploitation and optimization of the use of renewable energy sources, both on-grid as well as off-grid. 
- Enlist the support of other countries and international organizations in finance, capacity building and technology in the implementation of climate change strategies and policies.

- Facilitate international cooperation to implement FDI on climate change related projects. 


\section{GHG and non-GHG target:}

- Republic of Yemen proposes $14 \%$ GHG emission reduction target by 2030 below BAU which represents an estimated total cumulative GHG reduction of about 35 MtCO2eq from 2020 through 2030; this includes $1 \%$ unconditional target and $13 \%$ conditional target. As an unconditional target, Yemen aims to reduce $1 \%$ in GHG emissions by 2030 compared to a BAU scenario. As a conditional target, an additional $13 \%$ reduction achievable under certain conditions, which would bring the total GHG reduction to $14 \%$ below BAU emission levels by 2030 .

\section{Measures related to the energy sector}

- Unconditional mitigation measures are scheduled or in-progress projects, all of whose funding has been defined including those under implementation.

○ Mocha Wind Farm Project, 2014-2019, (MU\$ 144.00) - Government funding: (US\$ 19 Million)

○ Rural Energy Access Project, 2009-2017, (MU\$ 121.40) - Government funding: (US\$ 12.20 Million).

- Marib Gas Turbine Power Station 400 MW - phase 2 (Total Cost = US\$ 400 Million) Government funding (US\$ 49 Million).

- Expansion of Solar Power Technology in Yemen (US\$50 Million). The project is being implemented nationally, with a particular focus on piloting solar technologies in government buildings, schools, hospitals and the agricultural sector (solar water pumping).

- Efficient power generation, transmission and distribution. (15\% increase in energy efficiency in the power sector until 2025).

- Switch to efficient power generation for new generation capacities that are to be installed, these include:

- Combined-cycle gas turbine (CCGT) plants with overall efficiencies approaching to $60 \%$ for central (interconnected) power supply.

- Combined heat and power (CHP) generation systems with overall efficiencies of more than $80 \%$ appropriate for decentralized power supply for rural electrification, in industrial, commercial and residential sectors.

- Promotion of the use of renewable energy sources for electricity generation

- Off-grid electrification (electrification of individual rural Households-HH): 110.000 rural $\mathrm{HH}(45 \%$ of identified market potential) to be electrified Solar Home Systems until 2025 (installed capacity around $5.5 \mathrm{MWp}$ ).

- Rural electrification based on renewable energy (PV) systems, solar home systems (SHS), wind energy converters, where feasible, and biomass, both in stand-alone and hybrid schemes.

- Large-scale power generation from renewable energy sources (grid-connected), including solar thermal power plants, solar PV plants, and wind farms including:

- Grid electricity (large scale electricity generation): 15\% of generation mix in 2025 (2600 GWh). This translates into an overall installed capacity in 2025 of:

- $400 \mathrm{MW}$ from wind farms

- $160 \mathrm{MW}$ from geothermal power stations

- $6 \mathrm{MW}$ from power stations using landfill gas

- Promotion of the wide use of natural gas for power generation, industry and other economic sectors. 
- Promotion of the active use of solar energy through use of solar water heaters instead of electric water heaters and use of solar-driven air-conditioning and solar refrigeration. (Solar Water Heaters: $40 \%$ of market potential in 2025 (200,000 units) representing a saving potential of $457 \mathrm{GWh}$ ).

- Introduction of renewable energy sources in the industrial energy supplies concepts (solar water heaters, solar based process heat/stream, PV and wind systems)

- Methane capture from wastewater treatment plants; encouragement and expansion of renewable energy-based water desalination.

- Landfill gas capturing for flaring or using for power generation.

\section{Green industrial policies}

- Launch of energy-efficiency programs through establishing energy efficiency standards, energy use regulations and labeling and public awareness.

\section{Green government procurement}

- None.

Financial and direct trade measures (subsidies, carbon pricing, taxation, R\&D etc.)

- None.

\section{International Cooperation (climate finance, technology transfer, international mechanisms etc.)}

- Yemen's conditional target is conditional upon:

- Access to new sources of finance and enhanced support, compared to that received over the past years, to be mobilized through new climate finance mechanisms, such as the Green Climate Fund.

- Detailed cost estimation of required financial support will be updated in light of future circumstances by 2020 . 


\section{GHG and non-GHG target:}

- Zambia expects to reduce $38,000 \mathrm{Gg}$ CO2eq compared to $20,000 \mathrm{Gg}$ CO2eq under the domestic efforts with limited international support.

\section{Measures related to the energy sector}

- Renewable Energy and Energy Efficiency Program involves implementing: fuel switch (diesel/HFO to biodiesel); fuel switch (coal to biomass); switch from existing isolated diesel to mini-hydro; introudction of and increase in blending of bio-fuels with fossil fuels and when possible substitution with bio-fuels;; off-grid RE to non-electrified rural -PV and Wind; on grid expansion program to support economic growth and grid extension through inter-basic water transfer; grid extension to non-electrified rural areas.

\section{Green industrial policies}

- None.

\section{Green government procurement}

- None.

Financial and direct trade measures (subsidies, carbon pricing, taxation, R\&D etc.)

- None.

International Cooperation (climate finance, technology transfer, international mechanisms etc.)

- Meeting the conditional target requires an overall investment estimated at $\$ 35$ billion up to 2030, to be mobilized through new climate finance mechanisms such as; Green Climate Fund (GCF) and other climate related bilateral, multilateral and domestic financing including private sector.

- Zambia's contribution will be implemented with both domestic and international support. It is estimated that over $\$ 50$ billion is required for both mitigation ( $\$ 35$ billion for Domestic efforts with substantial International support) and adaptation (\$20 billion) actions across the programs upto 2030. Of this, $\$ 15$ billion will be unconditional support provided by the Zambian Government and $\$ 35$ billion will be conditional support to be sourced externally.

- Zambia does not rule out the possibility of using market based mechanisms in meeting emission reduction target. 


\section{GHG and non-GHG target:}

- Zimbabwe commits to have mitigation contribution as $33 \%$ below the projected Business As Usual energy emissions per capita by 2030.

\section{Measures related to the energy sector}

- Zimbabwe is working towards universal access to cleaner energy by 2030 through various measures:

- Stepwise increase in Kariba Power Station (hydro power plant) from 666 to 750 MW and then $1050 \mathrm{MW}$. Work on this plant is underway.

- Promotion of the use of liquefied petroleum gas (LPG) as the substitute for or alternative to grid electricity.

- Construction institutional biogas digesters (50 to $80 \mathrm{~m} 3$ in size) in all provinces with a target of at least 1,250 digesters by 2030 .

- Mini-hydros are already being constructed by Independent Power Producers (IPPs) and the mini-hydro installed capacity and is expected to rise to $27 \mathrm{MW}$ early 2016.

\section{Green industrial policies}

- Recognition of and reward for companies making efforts in the area of energy efficiency and carbon footprint to promote good behavior.

\section{Green government procurement}

- None.

Financial and direct trade measures (subsidies, carbon pricing, taxation, R\&D etc.)

- None.

International Cooperation (climate finance, technology transfer, international mechanisms etc.)

- This contribution target is subject to the following condition as a minimum: full implementation by developed countries of their commitments relating to finance, technology and capacity building and full, effective and sustained implementation of the Convention

- The target is also conditional to contributions by developed countries on all elements relating to mitigation, adaptation, finance, technology development and transfer and capacity building in the context of a global and comprehensive agreement for the period beyond 2020.

- Aims to leverage on the resources including carbon credits or selling of emission reduction units through international and regional carbon markets and/or carbon pricing mechanisms to mobilise more resources for managing climate change. 
Annex 2: INDCs/NDCs with no official or unofficial translation submitted 


\section{ANDORRE}

\section{GHG and non-GHG target}

- Réduction des émissions équivalentes non absorbées de 37\% (193,73 Gg CO2 éq.) par rapport aux émissions non absorbées du scénario BAU, d'ici 2030.

Measures related to the energy sector

- Aucun, mais le secteur de l'énergie est explicitement couvert par les CPDN.

\section{Green industrial policies}

- None.

\section{Green government procurement}

- None.

Financial and direct trade measures (subsidies, carbon pricing, taxation, R\&D etc.)

- None.

International cooperation (climate finance, technology transfer, international mechanisms etc.)

- Aucune contribution des crédits internationaux. 


\section{GHG and non-GHG target}

- Le Bénin prévoit réduire ses émissions cumulées de Gaz à Effet de Serre (hors secteur foresterie) par rapport au scénario de maintien du statu quo d'environ 21,4 \% sur la période 2021 à 2030.

- La contribution inconditionnelle correspond à une réduction des émissions de GES de 3,5\% par rapport au scénario BAU en 2030. La contribution conditionnelle permettrait une réduction de $17,9 \%$ des émissions supplémentaires.

\section{Measures related to the energy sector}

- Acroissement de la capacité nationale de production d'énergie électrique et promotion de l'utilisation du gaz naturel et des énergies renouvelables dans la production d'électricité à partir (i) des centrales bicombustibles pouvant fonctionner au fioul ou au gaz naturel (400 MW), (ii) des centrales hydroélectriques (quatre centrales hydroélectriques totalisant une capacité à installer de 396,6 MW); (iii) des centrales solaires photovoltaïque (54,2 MWc).

- Construction au port de Cotonou d'une unité de stockage et de regazéification de gaz naturel liquéfié + pipeline de raccordement au gazoduc.

\section{Green industrial policies}

- None.

\section{Green government procurement}

- None.

Financial and direct trade measures (subsidies, carbon pricing, taxation, R\&D etc.)

- Taxation différentielle en faveur des véhicules d'occasion âgés d'au plus cinq ans.

- Exonération des droits d'impôts sur les véhicules de transport en commun.

- Exonération fiscale et douanière sur les motocyclettes à 4T et leurs pièces détachées.

\section{International cooperation (climate finance, technology transfer, international mechanisms etc.)}

- Les activités prévues dans le cadre de la mise en œuvre de la CPDN requièrent un appui extérieur (bilatéral ou multilatéral) que s'élève à 27,81 milliards de dollars US en option conditionnelle.

- Soutien conditionnelle à la recherche scientifique, technique et technologique en matière d'adaptation et d'atténuation aux changements climatiques.

- Soutien conditionnelle à le transfert de technologie et savoir-faire en matière d'adaptation et d'atténuation aux changements climatiques. 


\section{GHG and non-GHG target}

- Réduction des émissions de GES à hauteur de 32\% par rapport à un scénario de référence pour l'année cible (2035), et conditionnée au soutien de la communauté internationale sous forme de financement, d'actions de renforcements de capacité et de transfert de technologies.

\section{Measures related to the energy sector}

- Mise en œuvre du Plan directeur d'électrification rurale.

- Promotion du développement des "mini- smart-grids" en zone rurale.

\section{Green industrial policies}

- Audits obligatoires et réguliers dans les grosses industries à forte intensité énergétique.

- Sensibilisation et encouragement des audits énergétiques dans les PME.

- Optimisation des procédés via des technologies plus efficientes ainsi que par le lissage et l'effacement.

- Évaluation des potentiels de substitution ou d'optimisation (par exemple cogénération ou valorisation)

- Limitation des pertes (torchages, réseaux, gaspillage) par l'application des réglementations, ainsi que par des normes, tarifications et incitations.

- Révision du code du bâtiment pour améliorer la performance énergétique par des normes thermiques de construction et de rénovation, et un processus de certification.

\section{Green government procurement}

- None.

Financial and direct trade measures (subsidies, carbon pricing, taxation, R\&D etc.)

- Développement des incitations économiques pour promouvoir l'efficacité énergétique.

- Cadre incitatif pour le développement des énergies renouvelables (appel d'offre, tarifs de rachat, etc.) et lever les barrières à l'investissement (renforcement du cadre institutionnel, etc.).

- Facilitations financières pour l'éclairage rural comme le Fonds d'électrification rurale (FER).

- Mise au rebut des plus polluants via des normes, incitations ou obligations.

- Financial measures related to environmental goods and services

○ Soutien à l'achat de véhicules peu polluants.

International cooperation (climate finance, technology transfer, international mechanisms etc.)

- Renforcement et promotion de l'intégration et la participation du Cameroun dans le marché sous régional de l'Energie, à travers l'interconnexion avec les autres pays de la sous-région, notamment le Pool énergétique d'Afrique Centrale (PEAC) et l'Afrique de l'Ouest via le Nigéria (WAPP). 


\section{GHG and non-GHG target}

- L'ambition de l'Union des Comores est de réduire ses émissions de GES en 2030 de $84 \%$ environ par rapport au scénario BAU. Cet engagement ne pourrait être atteint qu'avec l'accompagnement de la communauté internationale pour permettre à I'Union des Comores d'accéder à des sources de financement additionnelles notamment grâce aux nouveaux mécanismes de la finance climat, ou le Fonds Vert pour le Climat.

\section{Measures related to the energy sector}

- Reduction des pertes sur le réseau de distribution électrique.

- Réhabilitation des centrales électriques; adoption du solaire; renforcement du potentiel hydro; géothermie, biogaz.

- Promotion de l'utilisation du GPL à la place du pétrole et du bois.

\section{Green industrial policies}

- None.

\section{Green government procurement}

- None.

Financial and direct trade measures (subsidies, carbon pricing, taxation, R\&D etc.)

- None.

\section{International cooperation (climate finance, technology transfer / international mechanisms etc.)}

- Tous les projets d'adaptation sont financés par l'aide extérieure. L'Union des Comores aura besoin d'une enveloppe tournant autour de 675 million US\$ pour mener à bien la mise en œuvre de sa CPDN dont 375 millions de dollars pour les mesures d'atténuation et 300 millions pour les mesures d'adaptation.

- Les besoins en renforcement des capacités comprennent la capacité humaine dans divers domaines, la capacité institutionnelle, le cadre légal, juridique et financier, une meilleure planification en terme de politique, stratégie et plan d'action; et un meilleur suivi des opération.

- Les besoins en technologies comprennent en matière d'atténuation des technologies sur les énergies renouvelables telles le solaire, l'hydraulique, l'éolienne et la géothermie, l'efficience énergétique dans l'industrie du bâtiment et autres. 


\section{GHG and non-GHG target}

- Au moins $48 \%$ de réduction des émissions par rapport au scénario BAU en 2025 et de 55 \% en 2035, dans un scénario bas-carbone conditionnel (dépendant de l'appui de la communauté internationale).

\section{Measures related to the energy sector}

- Plan d'électrification solaire des villages isolés et du développement de l'hydroélectricité.

- Les émissions liées au torchage du gaz associé à la production pétrolière ont fait l'objet de plusieurs mesures, cadrant avec la participation du Congo dès cette année à l'initiative "Zéro Torchage de Routine d'ici 2030». Le gaz non torché est en partie valorisé dans deux nouvelles centrales à gaz à Djéno (50MW) et à Côte Maltève (300MW).

\section{Green industrial policies}

- Il est proposé en scénario bas-carbone d'augmenter la part des énergies renouvelables à utiliser pour l'extraction des produits miniers à hauteur de $90 \%$ en 2025 puis à $95 \%$ en 2035 (utilisation de la biomasse issue de plantations en savane en complément de l'hydroélectricité).

- Les investissements industriels auraient l'obligation d'appliquer une éthique environnementale et sociale et ils devraient respecter les conditions suivantes: (i) mise en place d'un ensemble d'infrastructures routières, électriques et portuaires permettant une production " verte » et une bonne circulation des produits notamment à l'export; (ii) implication de l'État ainsi que des investisseurs congolais dans le secteur industriel, le secteur tertiaire ou encore dans le bâtiment; (iii) coopération d'investisseur privés et de banques congolaises avec des investisseurs et des financeurs internationaux pour le financement d'investissements industriels.

\section{Green government procurement}

- None.

Financial and direct trade measures (subsidies, carbon pricing, taxation, R\&D etc.)

- None.

International cooperation (climate finance, technology transfer, international mechanisms etc.)

- La communauté internationale serait sollicitée à hauteur de 5,14 milliards d'euros pour la période 2015-2025. 


\section{GHG and non-GHG target}

- La RDC s'engage à réduire ses émissions de 17\% d'ici 2030 par rapport aux émissions du scénario des émissions BAU (430 Mt CO2e), soit une réduction d'un peu plus de 70 Mt CO2e évités (conditionelle).

\section{Measures related to the energy sector}

- Hydroelectrification rurale et urbaine.

- Réhabilitation des exploitations minières et pétrolières.

\section{Green industrial policies}

- None.

\section{Green government procurement}

- None.

Financial and direct trade measures (subsidies, carbon pricing, taxation, R\&D etc.)

- None.

International cooperation (climate finance, technology transfer, international mechanisms etc.)

- Les actions de la RDC seront conditionnées par la mise à disposition d'un appui adéquat correspondant en termes de ressources financières, de transfert de technologie et de renforcement de la capacité nationale. 


\section{GHG and non-GHG target}

- Réduction des émissions de GES de 28\% par rapport aux émissions de l'année cible (2030) dans un scénario BAU.

- Un cumul de 42\% d'énergies renouvelables dans le mix électrique en 2030.

\section{Measures related to the energy sector}

- Facilitation du développement de projets sur les filières pertinentes: (i) petite hydroélectricité; (ii) Méthanisation (déchets, résidus agricoles...); PVs (promotion des Kits PV solaire, système de pompage $\mathrm{PV}$...); biomasse (exploitation durable de bois énergie).

- Reduction des barrières à l'investissement (renforcement du cadre institutionnel, sécurisation des investissements, formation des banques, ...).

- Investissement dans l'efficacité énergétique et amélioration du taux de participation des EnR dans le mix électrique à l'horizon 2030.

\section{Green industrial policies}

- Réduction des gaspillages dans la consommation énergétique des industries à travers le diagnostic ou l'audit énergétique; le comptage pour disposer de données fiables et continues sur; la consommation.

- Développement d'une réglementation nationale sur l'efficacité thermique des bâtiments.

- Encouragement des entreprises à investir dans des équipements énergétiquement plus performants.

\section{Green government procurement}

- None.

Financial and direct trade measures (subsidies, carbon pricing, taxation, R\&D etc.)

- Investissements dans la R\&D et renforcement des capacités de l'Institut de Recherche sur les Energies Renouvelables (IREN).

- Mise au rebut des plus polluants via des normes, incitations ou obligations

- Financial measures related to environmental goods and services

$\circ \quad$ Mettre en place un cadre incitatif pour le développement des énergies renouvelables (appel d'offre, FIT, défiscalisation).

- Facilitation de l'achat de véhicules peu polluants.

\section{International cooperation (climate finance, technology transfer, international mechanisms etc.)}

- Renforcement de l'intégration de la Côte d'Ivoire dans le marché Régional de l'Energie, à travers l'interconnexion avec les autres pays de la région.

- La Côte d'Ivoire sollicitera l'appui des bailleurs de fonds et PTF (dons, prêts et assistance technique) pour le financement des actions de ces INDC. L'accès aux prêts souverains des Institutions financières de développement (IFD) sera crucial. 
- La Côte d'Ivoire réfléchit à l'opportunité de mettre en place une entité nationale accréditée au Fonds Vert pour le Climat (FVC). Elle a déjà entrepris son processus de préparation pour l'opérationnalisation du FVC au niveau national (Readiness Programme).

- La Côte d'Ivoire soutient l'inclusion des marchés internationaux du carbone tels que le Mécanisme pour un Développement Propre (MDP) dans l'accord sur le climat et propose qu'un tel instrument, couplé à un régime comptable approprié (MRV), puisse être utilisé pour aider à financer certains investissements dans les infrastructures sobres en carbone et résilientes au changement climatique.

- La Côte d'Ivoire considère que certaines des options de développement sobres en carbone contenues dans ces INDC, ou des actions supplémentaires, pourraient être financées entièrement ou en partie, par le transfert international d'actifs carbone en tenant compte des considérations d'intégrité de l'environnement et de transparence. 


\section{GHG and non-GHG target}

- Ninguno. El monto de su contribución dependerá del cumplimiento de las obligaciones internacionales establecidas bajo la Convención.

\section{Measures related to the energy sector}

- Construcción de 19 bioeléctricas anexas a los centrales azucareros con 755 MW a partir de la biomasa cañera y forestal; 13 parques eólicos con 633 MW; 700 MW Fotovoltaicos y 74 pequeñas centrales hidroeléctricas.

- Aprovechamiento de los residuos orgánicos para la producción de biogás.

\section{Green industrial policies}

- Instalación de 200 mil m2 de calentadores solares en los sectores residencial e industrial.

\section{Green government procurement}

- Instalación de tecnología LED con la distribución de 13 millones de lámparas en el sector residencial y de 250 mil luminarias para el alumbrado público.

Financial and direct trade measures (subsidies, carbon pricing, taxation, R\&D etc.)

- None.

International cooperation (climate finance, technology transfer, international mechanisms etc.)

- Cuba reafirma su voluntad para seguir cooperando en el desarrollo de capacidades en el enfrentamiento al cambio climático, en especial los pequeños estados insulares. 


\section{GHG and non-GHG target}

- Ninguno. Algunas metas de carácter cuantitativo hacia el año 2025 y 2030 serán debidamente consensuadas, cuantificadas y presentadas en algunos casos antes de las COP 22 y COP23.

\section{Measures related to the energy sector}

- Antes de la COP 22 el sector de generación de energía eléctrica definirá y se comprometerá con una meta de incremento de energía renovable para el año 2025 no inferior al 12\% con respecto a la energía eléctrica total generada en el país en el año 2014; y definirá y alcanzará una meta de reducción de emisiones de GEI para el año 2025.

\section{Green industrial policies}

- Normativa para mejorar la calidad del combustible diésel servido en el país, a implementarse a partir de 2018.

- Propuesta para mejorar y mantener, de manera sostenida, la calidad del parque vehicular privado, del transporte público y de carga, con metas definidas para 2025.

\section{Green government procurement}

- None.

\section{Financial and direct trade measures (subsidies, carbon pricing, taxation, R\&D etc.)}

- Incentivos y sistemas comunitarios para reducir el alto costo de eco-eficiencia, sobre todo en las clases socioeconómicas de bajos ingresos para la mejora del confort térmico en viviendas y oficinas (arquitectura bioclimática, eficiencia energética, microclima, islas de calor).

\section{International cooperation (climate finance, technology transfer, international mechanisms etc.)}

- Recursos financieros internacionales disponibles para apoyar los compromisos mencionados, los cuales deberán ser nuevos y adicionales a la ayuda oficial al desarrollo; asegurando no solo el fortalecimiento de las capacidades nacionales sino también el acceso adecuado a tecnologías, entre otro tipo de cooperación.

- El Salvador requiere para la implementación de las Contribuciones Previstas acceso efectivo a mecanismos de financiamiento como el Fondo Verde del Clima (GCF) y mecanismos tecnológicos tales como el Centro y Red de Tecnología del Clima (CTCN). 


\section{GHG and non-GHG target}

- Guatemala planifica lograr una reducción del $11.2 \%$ de sus emisiones GEl totales del año base 2005 proyectado al año 2030 (unconditional). Guatemala plantea una reducción más ambiciosa que la anterior, de hasta el $22.6 \%$ de sus emisiones GEl totales del año base 2005 proyectado al año 2030 (conditional). Como condición para alcanzar esta meta ambiciosa, será necesario contar con el apoyo técnico y financiero necesario proveniente de recursos internacionales públicos y privados, nuevos y adicionales.

\section{Measures related to the energy sector}

- Aumento del aprovechamiento de fuentes renovables, para el año 2030, la generación eléctrica sea del $80 \%$ a partir de fuentes renovables.

- Seguridad del abastecimiento de electricidad a precios competitivos.

- Norma técnica para la conexión, operación, control y comercialización de la generación renovable -NTGDR- y los usuarios auto-productores con excedentes de energía.

\section{Green industrial policies}

- Desarrollo y coordinación para el involucramiento del sector privado a través de acciones enmarcadas en la Política de Producción más Limpia, que se implemente como una herramienta de la competitividad y la gestión ambiental.

\section{Green government procurement}

- None.

\section{Financial and direct trade measures (subsidies, carbon pricing, taxation, $R \& D$ etc.)}

- Ley de incentivos para el desarrollo de proyectos de energía removable

- Programa de Incentivos que motive actividades voluntarias de reducción o absorción de emisiones GEl.

- Se impulsara una normativa para establecer un programa de incentivos fiscales y subsidios enfocados en el uso de energías limpias para el transporte público y privado, incluyendo normativa para regular las emisiones de GEl en el transporte público colectivo e individual.

\section{International cooperation (climate finance, technology transfer, international mechanisms etc.)}

- Potencial participación del país en los mecanismos de mercado de carbono que sean estables.

- Los recursos del presupuesto del Estado no son suficientes para cubrir la extensa y profunda brecha para poder atender los efectos del cambio climático y alcanzar los compromisos del INDC y las metas de los ODS al 2030, la construcción de capacidades, la adaptación, la reducción de la vulnerabilidad y la mitigación. Razón por la cual el país hace un llamado a la comunidad internacional para que, cumpliendo con una responsabilidad común pero diferenciada, se provea al país de recursos financieros adicionales al financiamiento para el desarrollo. 


\section{GHG and non-GHG target}

- La ambición de Guinea Ecuatorial es reducir en un 20\% de sus emisiones para el año 2030, con respecto a los niveles de 2010; a fin de alcanzar una reducción de 50\% para el año 2050. Eso, condicionado a que el apoyo sea favorable, previsible $y$, que se viabilice los mecanismos de financiamiento climático y se corrijan las distorsiones de los mecanismos de mercado existentes.

\section{Measures related to the energy sector}

- Aprovechamiento del potencial hidroeléctrico del río Wele, para la electrificación de toda la Región Continental del país.

- Reforma y acondicionamiento de los centros hidroeléctricos de Musola (0.4-0.5 MW), Riaba (3.8 MW), para la electrificación de toda la isla de Bioko. Y Bikomo en la región continental (3.2 MW).

- Apuesta por las opciones de energía eólica, solar y/o mareomotriz para las islas remotas del país (Annobón, Corisco y otras).

\section{Green industrial policies}

- Fomento de la política industrial basada en el uso de nuevas tecnologías

- Adopción de directivas sobre tipos de maquinarias y fijar los límites de las emisiones

- Adopción de directivas sobre métodos de operación de producción óptima.

\section{Green government procurement}

- Adquisición de aeronaves dotadas de alta tecnología.

Financial and direct trade measures (subsidies, carbon pricing, taxation, R\&D etc.)

- None.

International Cooperation (climate finance, technology transfer international mechanisms etc.)

- None. 


\section{GHG and non-GHG target:}

- La République d'Haïti compte réduire ses émissions de $31 \%$ par rapport au scénario de développement tendanciel, représentant en valeur absolue $45.24 \mathrm{Mt}$ éq- $\mathrm{CO}_{2}$. Cet effort, est réparti comme suit:

- Objective inconditionnel: Réduction des émissions de $5 \%$ par rapport au scénario de reference (2000) à l'horizon 2030, soit un cumul de $10 \mathrm{Mt}$ éq- $\mathrm{CO}_{2}$.

- Objective conditionnel: Réduction des émissions de $26 \%$ supplémentaires par rapport scénario de développement tendanciel à l'horizon 2030, soit un cumul de 35.24 Mt éq$\mathrm{CO}_{2}$.

\section{Measures related to the energy sector}

- Installer à l'horizon 2020, 37.5 MW additionnels d'hydroélectricité (inconditionnel).

- Augmenter à $47 \%$ la part des énergies renouvelables dans le système électrique haïtien d'ici 2030 (hydro $24.5 \%$, éolien $9.4 \%$, solaire $7.5 \%$, biomasse $5.6 \%$ )

- Installer à l'horizon 2030 (4 Parcs Eoliens : $50 \mathrm{MW}$, Hydroélectricité : 60MW additionnels, Parcs solaires: $30 \mathrm{MW}$, Biomasse : $20 \mathrm{MW}$ )

- Améliorer l'efficacité énergétique des fours de production de charbons de bois (faire passer les rendements de $10-15 \%$ à $30-45 \%$ ).

\section{Green industrial policies}

- None.

\section{Green government procurement}

- None.

Financial and direct trade measures (subsidies, carbon pricing, taxation, R\&D etc.)

- Contrôler, réglementer l'importation des véhicules usages (inconditionnel).

- Financial measures related to environmental goods and services

- Promouvoir l'utilisation de réchauds éco énergétiques en remplacement des foyers traditionnels (gain d'énergie de $25-30 \%$ par réchaud).

\section{International cooperation (climate finance, technology transfer, international mechanisms etc.)}

- L'enveloppe financière globale pour la mise en œuvre des actions prévues dans cette contribution est évaluée à 25.387 milliards USD dont 16.614 milliards USD pour les actions d'adaptation et 8.773 milliards USD pour les actions d'atténuation. Les mesures d'atténuation conditionnelles et inconditionnelles représentent respectivement des montants de 7.999 milliards USD et 773.519 millions USD. 
GHG and non-GHG target:

- La República de Honduras se compromete a la reducción de un $15 \%$ de las emisiones respecto al escenario BAU para el 2030 para el conjunto de sectores contenido en este escenario BAU. Este compromiso está condicionado a que el apoyo sea favorable, previsible y se viabilicen los mecanismos de financiamiento climático.

\section{Measures related to the energy sector}

- Ninguna, pero el sector energético está mencionado explícitamente por el NDC.

\section{Green industrial policies}

- Ninguna, pero el sector de procesos industriales está mencionado explícitamente por el NDC.

\section{Green government procurement}

- None.

Financial and direct trade measures (subsidies, carbon pricing, taxation, R\&D etc.)

- None.

International cooperation (climate finance, technology transfer, international mechanisms etc.)

- None. 


\section{GHG and non-GHG target:}

- Le niveau des ambitions de réduction des GES du scénario d'atténuation par rapport au scénario de base ( $29 \%$ pour l'agriculture, $31 \%$ pour l'énergie et $21 \%$ pour les forêts).

- Les ambitions de réduction des émissions du scénario d'atténuation sont de 1486 kTéq CO2 en 2025 , soit une réduction de $22,4 \%$, et 2933 kTéq CO2 en 2030 , soit une réduction de $31,6 \%$. Le coût correspondant est de 580 millions de \$US sur cinq ans, soit 1,16 milliard de \$ US sur les dix ans.

\section{Measures related to the energy sector}

- Le programme de valorisation à grande échelle des énergies renouvelables (SREP) pour 258 millions de \$US.

- Le projet Manantali II qui sera réalisé entre 2016 et 2021 et coûtera 150 millions de dollars US.

- Le projet d'électrification villageoise par système d'énergies renouvelables qui sera réalisé entre 2015 et 2020 et coûtera 7,2 millions de \$US.

- Le projet de la centrale hydroélectrique de Kénié qui sera réalisé entre 2015 et 2020 et coûtera 165 millions de \$US.

\section{Green industrial policies}

- None.

\section{Green government procurement}

- None.

Financial and direct trade measures (subsidies, carbon pricing, taxation, R\&D etc.)

- None.

International cooperation (climate finance, technology transfer, international mechanisms etc.)

- None. 


\section{GHG and non-GHG target:}

- La République Islamique de Mauritanie a I'intention de contribuer à l'Accord Climat de Paris par une réduction de ses émissions de GES prévue en 2030 de 22,3\%, soit 4.2 Millions de tonnes équivalent dioxyde de carbone $\left(\mathrm{Mt}\right.$ eq $\left.\mathrm{CO}_{2}\right)$, par rapport aux émissions projetées pour la même année selon le scénario du cours normal des affaires (BAU) qui évolue de $6.6 \mathrm{Mt}$ eq $\mathrm{CO}_{2}$ en 2010 à 18.84 Mt eq $\mathrm{CO}_{2}$ En 2030. Ainsi, pour la période 2020-2030 le cumul des émissions évitées selon les mesures d'atténuation proposées sont d'environ $33,56 \mathrm{Mt}$ eq $\mathrm{CO}_{2}$.

- $12 \%$ de cette réduction potentielle des émissions pourront être réalisés par les moyens propres de la Mauritanie (part inconditionnelle de la Contribution).

- $\quad 88 \%$ de la contribution, correspondent à la part de réduction des émissions conditionnée à l'appui international (part conditionnelle de la Contribution).

\section{Measures related to the energy sector}

- None, but the INDC explicitly covers the energy sector.

\section{Green industrial policies}

- None, but the INDC explicitly covers industrial processes and product use sector.

\section{Green government procurement}

- None.

Financial and direct trade measures (subsidies, carbon pricing, taxation, R\&D etc.)

- None.

International cooperation (climate finance, technology transfer, international mechanisms etc.)

- Pour réaliser ses ambitions d'atténuation des GES en 2030, la Mauritanie aura besoin d'une enveloppe financière globale de 9,3 Milliards de Dollars US dont $88 \%$ (équivalents à 8,2 Milliards de Dollars US.) devant provenir de l'appui international. 
GHG and non-GHG target:

- Los esfuerzos nacionales de la República de Panamá incrementará en el sector energía en un $30 \%$ la capacidad instalada al 2050 (15\% para el 2030) proveniente de fuentes renovables no convencionales como la eólica y solar y en el sector UT-CUTS, con asistencia del Fondo Verde para el Clima por medio de un esquema pago por desempeño del y otros mecanismos financieros, permitirá el incremento de la capacidad de absorción de carbono en un $10 \%$ con respecto al escenario de referencia al 2050; y si el país recibe apoyo internacional en medios de implementación, la capacidad de absorción podrá incrementar hasta un $80 \%$ con respecto al escenario de referencia al 2050.

\section{Measures related to the energy sector}

- Utilizar combustibles con menor contenido de carbono.

- Impulsar el incremento de la inversión en energías otras fuentes renovables como solar, eólica y la biomasa (apoyandose en la ley 8 de 2015 y en el Plan Energético Nacional 2015-2050, específicamente en la línea de acción que contempla la descarbonización de la matriz eléctrica).

- Se identificaron diversos sitios que cumplen con las características necesarias para la instalación de turbinas eólicas o sistemas de paneles solares para su óptimo rendimiento. Para enero de 2016, existían según la Autoridad de Servicios Públicos (ASEP) licencias definitivas para la instalación de 1,184.1 Megavatios (MW) de otras energías renovables como la solar y eólica, equivalente al $41.8 \%$ de la capacidad instalada en el 2014.

- Licencias provisionales para la construcción de proyectos que generarán una capacidad instalada de 2,083.92 MW con otros tipos de fuentes de energías renovables.

- Impulsar el uso de nuevas tecnologías para obtener mejoras en la eficiencia, generación, almacenamiento, transmisión y distribución de energía.

- Revisión, unificación del marco regulatorio existente y establecimiento del mecanismo financiero que faciliten la inversión en otros tipos de fuentes de energías renovables por parte de actores públicos y privados.

\section{Green industrial policies}

- Modificar y crear nuevos marcos regulatorios de promoción de eficiencia energética.

\section{Green government procurement}

- None.

Financial and direct trade measures (subsidies, carbon pricing, taxation, R\&D etc.)

- Ley 37 de 2013, que establece el régimen de incentivos para el fomento de la construcción, operación y mantenimiento de centrales y/o instalaciones solares.

- Ley 44 de 2011 y Ley 18 de 2013, que establecen el régimen de incentivos para el fomento de la construcción y explotación de centrales eólicas destinadas a la prestación del servicio público de electricidad.

- Ley 45 de 2004, que establece un régimen de incentivos para el fomento de los sistemas de generación hidroeléctrica y de otras fuentes nuevas, renovables y limpias y dicta otras disposiciones. 
- Panamá contempla diseñar un mercado de carbono.

International cooperation (climate finance, technology transfer, international mechanisms etc.)

- Panama continuará participando en el comercio internacional de emisiones.

- El país tomará medidas voluntarias en los sectores marítimos y aéreos internacionales que faciliten el cumplimiento de estas industrias, en el marco de la Organización Marítima Internacional (OMI) y la Organización de Aviación Civil (OACl), por medio de medidas basadas en mercados.

- El compromiso de Panamá en la lucha contra el cambio climático también se hizo vigente por medio de la donación de 1 millón de USD al Fondo Verde del Clima (GCF). Panamá espera con esto contribuir a la implementación de políticas y proyectos de mitigación y adaptación alrededor del mundo. 


\section{GHG and non-GHG target:}

- Paraguay planifica lograr una reducción por un valor de 429 MtCO2eq durante el periodo de implementación de este plan de acción, y a partir del 2030 evitar emisiones por un total de 83 MtCO2eq en forma anual, establecidos de acuerdo a los cálculos de desarrollo proyectados en los estudios existentes.

- $20 \%$ de reducciones en base al comportamiento de las emisiones proyectadas al 2030.

- Meta Unilateral: 10\% de reducción de emisiones proyectadas al 2030.

- Meta Condicionada: 10\% de reducción de emisiones proyectadas al 2030.

\section{Measures related to the energy sector}

- Aumentar en $60 \%$ el consumo de energías renovables.

- Reducir en $20 \%$ el consumo de combustible fósil.

- Incorporar tecnologías para la explotación de nuevas fuentes de energía sustentable (incluye energía solar, eólica, biomasa).

\section{Green industrial policies}

- None.

\section{Green government procurement}

- None.

Financial and direct trade measures (subsidies, carbon pricing, taxation, R\&D etc.)

- Paraguay necesita promover la aplicación de recursos financieros necesarios para implementar planes, programas y proyectos de adaptación y mitigación al Cambio Climático en los siguientes sectores prioritarios: Energía, Industrias limpias, Infraestructura, Transporte.

\section{International cooperation (climate finance, technology transfer, international mechanisms etc.)}

- La contribución condicional requerirán de cooperación internacional en cuanto a financiamiento, transferencia de tecnología, creación de capacidades.

- Paraguay está impulsando mecanismos que promuevan la transferencia de tecnología, a fin de promover y facilitar la investigación y el análisis de las medidas tecnológicas y soluciones aplicables a la vulnerabilidad y adaptación a los efectos del Cambio Climático, incluyendo aquellas que garanticen la reducción de la pobreza, soberanía y seguridad alimentaria. 


\section{GHG and non-GHG target:}

- Sous l'option inconditionnelle (CPDN), les réductions d'émissions par rapport à leur trajectoire prévue sont de de $3 \%, 4 \%$ et $5 \%$ respectivement en 2020, 2025 et 2030. Avec l'option conditionnelle $(\mathrm{CPDN}+)$, les réductions d'émissions attendues sont de l'ordre de $7 \%, 15 \%$ et $21 \%$ sur les mêmes années.

\section{Measures related to the energy sector}

- Options inconditionelles - Programme EnR1:

- Solaire PV: centrales d'une puissance cumulée totale de $160 \mathrm{MWc}$.

- Éolienne: centrales d'une puissance cumulée totale $150 \mathrm{MW}$.

- Hydraulique: centrales d'une puissance cumulée totale de $144 \mathrm{MW} / 522 \mathrm{GWh}$.

- Electrification Rurale (PNUER).

- 392 villages électrifiés en mini-réseau électrifiés solaire ou hybride (diesel / solaire).

- Options conditionelles - Programme EnR2:

- Eoliennes: mise en service de centrales d'une puissance totale cumulée de $200 \mathrm{MW}$.

- Solaire PV: mise en service de centrales d'une puissance totale cumulée de $200 \mathrm{MWc}$.

- Biomasse: mise en service de centrales d'une puissance totale cumulée de $50 \mathrm{MW}$.

- Solaire - CSP: mise en service de centrales d'une puissance totale cumulée de $50 \mathrm{MW}$

- Hydraulique: Injection sur le réseau de 200 GWh supplémentaires en 2025.

- Remplacement de la centrale à charbon Jindal 320MW Charbon par deux centrales à Cycles Combinés au Gaz Naturel Liquéfié (CCGN) de 400 MW (2025: 200 MW et 2028: $200 \mathrm{MW}$ )

- 5000 villages électrifiés par voie solaire (mini-réseau) pour l'accès universel à l'électricité.

- Récupération énergétique du méthane et méthanisation (conditionelle).

- Valorisation des déchets dans l'Agro-industrie (biogaz).

- Gaz naturel: substituer $40 \%$ du charbon dédié à l'autoproduction d'électricité par du gaz naturel (conditionelle).

\section{Green industrial policies}

- Substitution du CO2 au Clinker dans la fabrication du ciment (conditionelle).

- Audits obligatoires pour les grandes entreprises.

- Études d'approvisionnement en énergie pour les nouvelles installations (75 études/an).

\section{Green government procurement}

- Programme d'efficacité énergétique dans l'administration (conditionelle).

- Efficacité énergétique de l'éclairage public (remplacement de 75000 lampadaires).

\section{Financial and direct trade measures (subsidies, carbon pricing, taxation, $R \& D$ etc.)}

- Les besoins en financement de la contribution inconditionnelle s'élèvent à plus de 1,8 Milliards de dollars US.

- Mise à niveau environnementale des entreprises, avec des incitations financières. 
International cooperation (climate finance, technology transfer, international mechanisms etc.)

- Les besoins en financement de la contribution conditionnelle s'élèvent à 5 Milliards dollars US. Le financement de la contribution conditionnelle est attendu dans le cadre des mécanismes financiers qui accompagneront l'Accord.

- Un besoin d'assistance technique pour combler les lacunes et expertises pour le développement a été identifié pour accompagner l'implantation, l'exploitation et la maintenance durable des technologies suivantes: Centrales à Cycles Combinés au Gaz Naturel; CSP (TES + Dessalement + GN); Éoliennes à aimant permanant et entrainement direct; Logistique du Gaz Naturel et infrastructures requises; système de co/tri-génération; système de surveillance, de mesure et de suivi.

- Le Sénégal n'a pas l'intention de réaliser sa contribution en achetant des unités de réduction d'émissions issues de tout mécanisme de marché existant ou à venir. Néanmoins, le Sénégal sera un pays d'accueil de projets de tout mécanisme international sur le climat visant à assurer la protection de la planète par le respect des normes qui offrent des résultats réels, permanents, supplémentaires et vérifiés tout en évitant le double comptage des émissions et répondant à ses objectifs de développement durable.

- Le Sénégal soutient la poursuite du Mécanisme de Développement Propre (MDP) établi en vertu du Protocole de Kyoto et sa poursuite sous une forme à définir dans le cadre du nouvel Accord. 


\section{GHG and non-GHG target}

- Au moins 50\% de réduction des émissions par rapport au scénario BAU en 2025.

\section{Measures related to the energy sector}

- Plan d'électrification solaire des villages isolés.

- Développement de l'hydroélectricité, avec comme objectif d'assurer à horizon 2025 une fourniture de l'électricité basée à $80 \%$ sur l'hydroélectricité et $20 \%$ sur le gaz.

- Adhésion en 2007 à l'initiative «Global Gas Flaring Reduction» (GGFR) de la Banque Mondiale, la promulgation en 2014 de la loi $N^{\circ}$ 011/2014 interdisant le torchage en continu au Gabon) et ce, cadrant avec la participation du Gabon à l'initiative « Zéro Torchage de Routine d'ici 2030». Gabon reconnait un droit de récupération sur la zone d'exploitation aux opérateurs qui investissent en unité de compression. Ceci équivaut donc à un remboursement de l'ensemble de ces coûts aux opérateurs.

\section{Green industrial policies}

- Interdiction de l'importation de véhicules de plus de 3 ans.

\section{Green government procurement}

- None.

Financial and direct trade measures (subsidies, carbon pricing, taxation, R\&D etc.)

- Mise en place d'un Fonds National de Développement Durable. La création de ce fonds est à l'étude et se positionnera dans la lignée des Fonds Nationaux Climat qui se développent dans divers pays.

- Marché domestique: le Loi portant orientation du développement durable au Gabon instaure un mécanisme vertueux par lequel les activités qui se développent doivent effectuer au préalable un bilan de leurs impacts (I'Etude d'Impact Développement Durable), mener un Plan de Gestion afin de les maîtriser et les réduire, et compenser les effets négatifs incompressibles.

\section{International cooperation (climate finance, technology transfer, international mechanisms etc.)}

- Pas de réduction à partir d'achats de crédits carbone hors Gabon.

- Le Gabon prend en charge ses propres choix et recherche en parallèle à établir des partenariats avec des programmes en accord avec la stratégie présentée dans le CPDN. Les différents champs d'action à financer en matière de réduction des émissions, en accompagnement des dispositions stratégiques présentées dans cette contribution nationale sont en particulier des projets d'énergie renouvelable, en particulier hydroélectrique, de traitement des eaux usées et autres déchets, d'efficacité énergétique, de transfert de technologies, d'affectation des terres, tant en matière de planification de l'aménagement du territoire, comme des projets agricoles et forestiers. 


\section{GHG and non-GHG target:}

- El Plan Nacional de Mitigación apuntará a la reducción de las emisiones del país en al menos un 20\% para 2030 en relación al escenario inercial, entendido este como un escenario hipotético en el cual no se implementa el plan. El grado en que se alcance esta meta dependerá del cumplimiento de los compromisos de los países desarrollados en cuanto a provisión de financiamiento, transferencia de tecnología y formación de capacidades de acuerdo al Artículo 4.7 de la Convención.

\section{Measures related to the energy sector}

- Cerca del $70 \%$ de la energía en Venezuela es hidroeléctrica, esto implica que el país es excepcionalmente limpio en su matriz energética pero a la vez altamente vulnerable a sequias.

- Construcción de dos parques de generación eólica de alta capacidad (Paraguaná y la Guajira).

- Implementación del Programa Sembrando Luz que permite dotar de servicio eléctrico a comunidades aisladas, a través de sistemas híbridos de energía eólica y solar. El manejo de las instalaciones asociadas ha implicado 1.327 acciones de capacitación con 14.617 beneficiados.

- La industria desarrolla actualmente un importante número de Proyectos para la minimización o aprovechamiento del gas quemado y/o venteado por PDVSA en sus operaciones de exploración y producción; esto implica la adecuación de las operaciones y las instalaciones en términos de infraestructura y facilidades para el aprovechamiento del gas natural.

\section{Green industrial policies}

- Proyecto nacional de eliminación progresiva de las sustancias agotadoras de la capa de ozono: principalmente en refrigeración, aire acondicionado y espumas de poliuretano. mediante el plan de formación y sensibilización de los actores involucrados sobre el peligro ambiental que representa el uso indebido de los refrigerantes halogenados, así como la adecuación de la norma legal correspondiente. Esto ha significado la reducción de 2.5 MTon CO2Eq.

- Promulgación de normativa legal sobre Eficiencia Energética: Ley de uso racional y eficiente de la energía; Resoluciones sobre Eficiencia Energética para el Sector Público y Privado; Reglamentos Técnicos sobre parámetros de eficiencia energética en artefactos eléctricos: A/A, Refrigeradores, LFC. Prohibición gradual de importación de bombillos incandescentes. Normas de etiquetado de eficiencia energética; tarifas eléctricas escalonadas de acuerdo a consumo, prohibición de importación de dispositivos ineficientes.

- Promover sistemas constructivos no contaminantes y sistemas de viviendas ecoeficientes.

- Resoluciones ministeriales para reducción de consumo eléctrico en el sector público y privado. Obteniéndose a la fecha una reducción de $12 \%$ en el consumo de energía eléctrica para el sector público y de $8 \%$ para el sector privado.

- Establecer a la chatarra ferrosa y no ferrosa como un insumo de interés nacional para el proceso productivo, a efecto de atender la estructura de costos de los productos y el cuidado del ambiente así como eficiencia energética.

\section{Green government procurement}

- None. 
Financial and direct trade measures (subsidies, carbon pricing, taxation, R\&D etc.)

- Prohibición gradual de importación de bombillos incandescentes.

- Tarifas eléctricas escalonadas de acuerdo a consume

- Prohibición de importación de dispositivos ineficientes.

International cooperation (climate finance, technology transfer, international mechanisms etc.)

- Desmontar los esquemas de mercados internacionales de carbono que legitiman la compra de derechos de contaminación y la impune destrucción del planeta.

- El grado en que se alcance esta meta dependerá del cumplimiento de los compromisos de los países desarrollados en cuanto a provisión de financiamiento, transferencia de tecnología y formación de capacidades de acuerdo al Artículo 4.7 de la Convención.

- Fomentar medios de pago alternativos que trasciendan el uso de monedas (de papel y metálicas), facilitando el establecimiento del comercio justo entre los pueblos suramericanos y países aliados, a la vez que se modifique la influencia del dólar estadounidense como patrón referencial en el comercio internacional. 